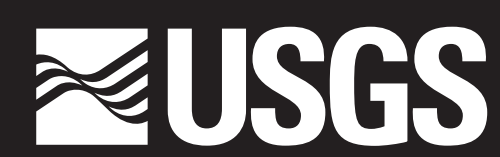

science for a changing world

\title{
Selenium in Ecosystems within the Mountaintop Coal Mining and Valley-Fill Region of Southern West Virginia- Assessment and Ecosystem-Scale Modeling
}

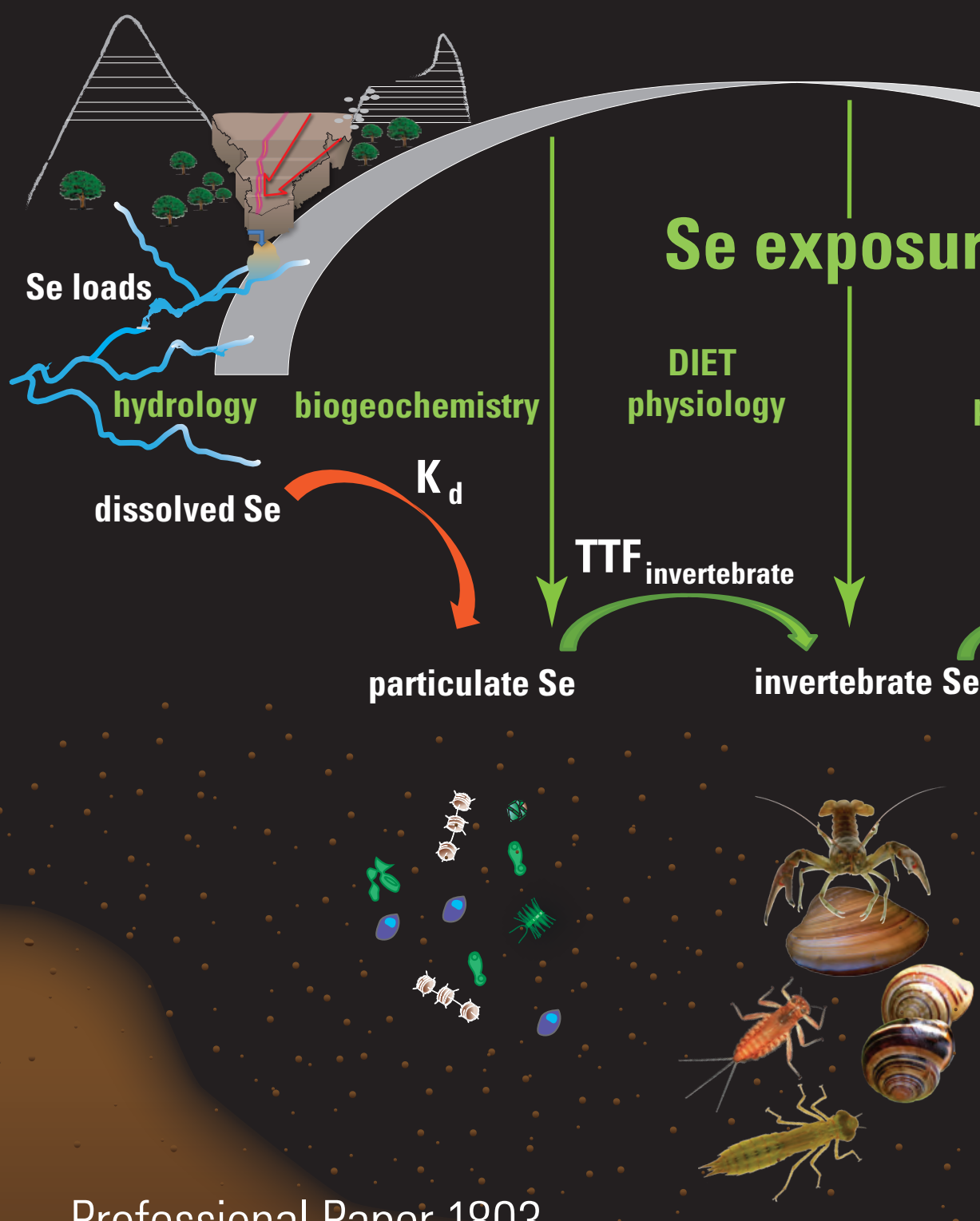

Professional Paper 1803

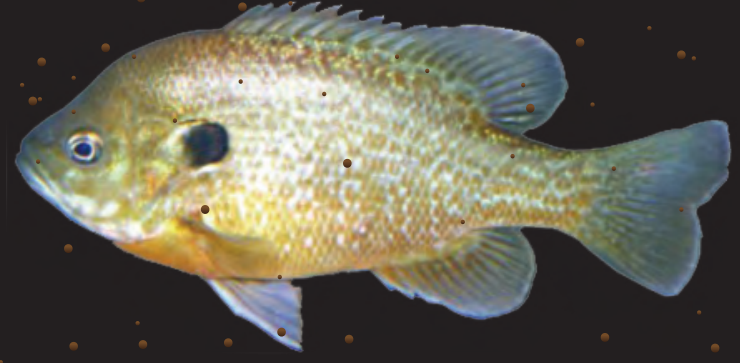

U.S. Department of the Interior

U.S. Geological Survey 
COVER

Schematic of ecosystem-scale selenium modeling specific to southern West Virginia. Illustrated food webs include: suspended particulate material, crayfish, clam, orb snail, mayfly larvae, stonefly larvae, creek chub, stoneroller, and bluegill sunfish. Cover and graphics by Jeanne DiLeo. 


\section{Selenium in Ecosystems within the Mountaintop Coal Mining and Valley- \\ Fill Region of Southern West Virginia- Assessment and Ecosystem-Scale Modeling}

By Theresa S. Presser

Professional Paper 1803 


\section{U.S. Department of the Interior SALLY JEWELL, Secretary}

\section{U.S. Geological Survey \\ Suzette M. Kimball, Acting Director}

\section{U.S. Geological Survey, Reston, Virginia: 2013}

For product and ordering information: World Wide Web: http://www.usgs.gov/pubprod Telephone: 1-888-ASK-USGS

For more information on the USGS - the Federal source for science about the Earth, its natural and living resources, natural hazards, and the environment:

World Wide Web: http://www.usgs.gov

Telephone: 1-888-ASK-USGS

Any use of trade, firm, or product names is for descriptive purposes only and does not imply endorsement by the U.S. Government.

Although this information product, for the most part, is in the public domain, it also may contain copyrighted materials as noted in the text. Permission to reproduce copyrighted items must be secured from the copyright owner.

Part or all of this report is presented is Portable Document Format (PDF). For best results viewing and printing PDF documents, it is recommended that you download the documents to your computer and open them with Adobe Reader. PDF documents opened from your browser may not display or print as intended. Download the latest version of Adobe Reader, free of charge.

Suggested citation:

Presser, T.S., 2013, Selenium in ecosystems within the mountaintop coal mining and valley-fill region of southern West Virginia—assessment and ecosystem-scale modeling: U.S. Geological Survey Professional Paper 1803, 86 p. http://dx.doi.org/10.3133/pp1803. 


\section{Contents}

Abstract

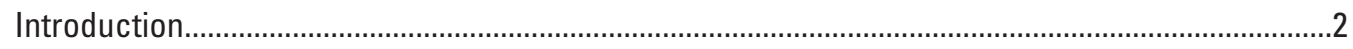

Site-Specific Setting, Sources, and Background ...................................................................

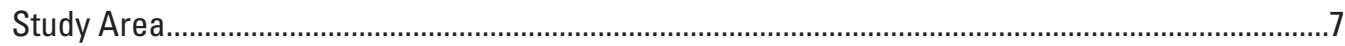

Sites and Sampling Design ...........................................................................................

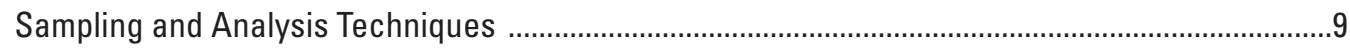

Monitoring Schedule and Collection Methods ................................................................

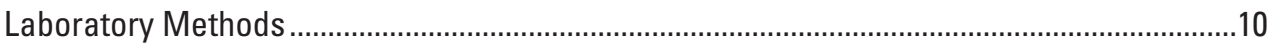

Chemical Procedures...................................................................................................

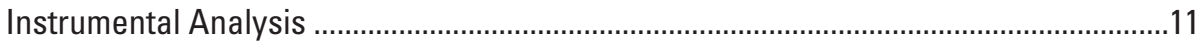

Modeling Approach: Ecosystem-Scale Selenium Modeling..........................................................11

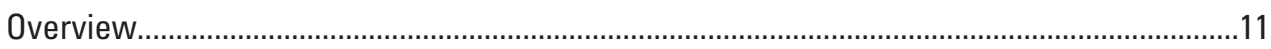

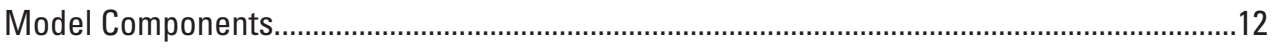

Partitioning/Transformation from Dissolved to Particulate Phase: Selenium Concentrations in Particulates at the Base of the Food Web..............................12

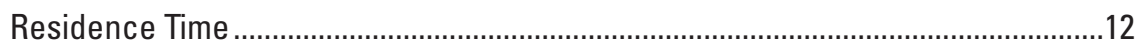

Particle Type and Data Requirements....................................................................13

Uptake into Food Webs and TTFs: Selenium Concentrations in Prey and Predators ....13

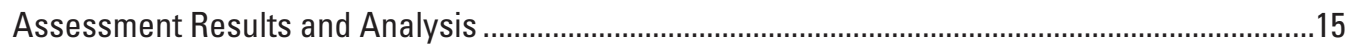

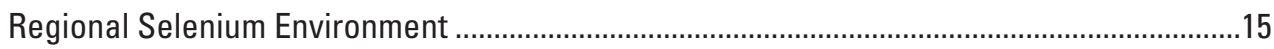

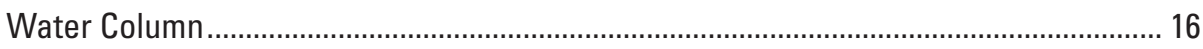

Suspended Particulate Material ......................................................................................16

Food Web: Invertebrates, Fish, and Amphibians..........................................................18

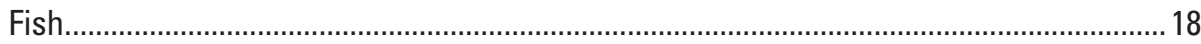

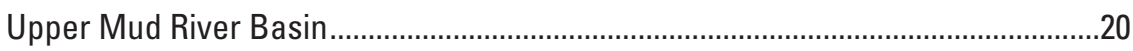

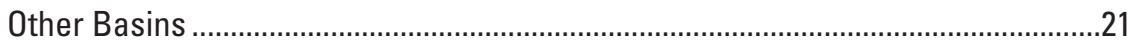

Sampled Ecosystems: Site Schematics and Assessed Ecosystems ....................................21

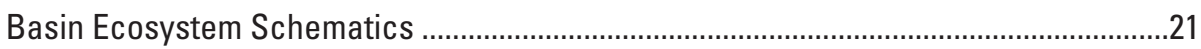

Assessed Food Webs: Water, Particulate Material, Invertebrate, and Fish...................22

Comparative Analysis of Selenium Concentrations and Species: Invertebrates

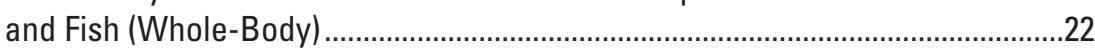

Comparative Analysis of Selenium Concentrations: Fish (Whole-Body and Ovary) ......28

Comparative Analysis of Selenium Concentrations: Dissolved and Suspended

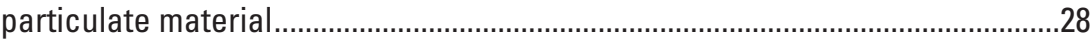

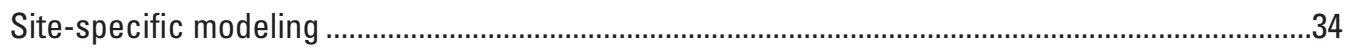

Conceptual Models and Exposure Scenarios.......................................................................

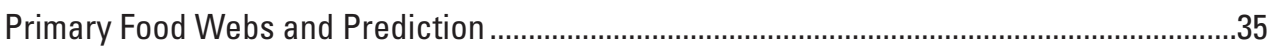

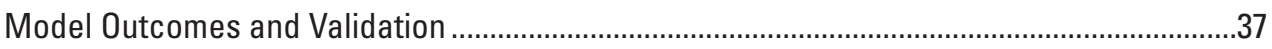

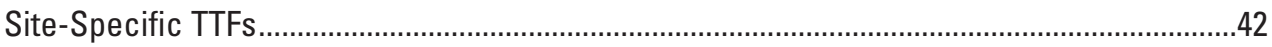

Conversion Factor: Whole-Body to Ovary ....................................................................... 43

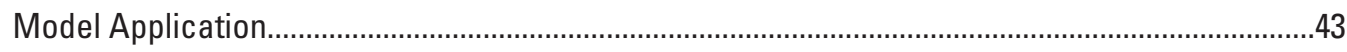

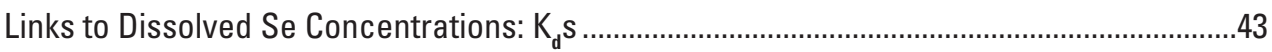

Derivation of Dissolved Selenium Concentrations................................................................45 


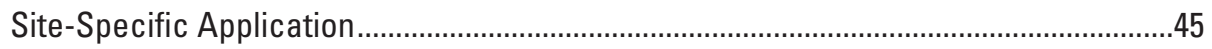

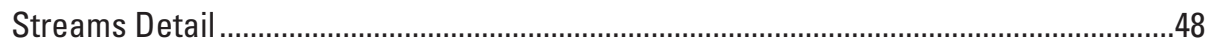

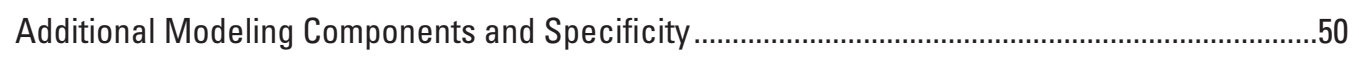

Fish Species: Abundance, Richness, and Deformity .............................................................50

Temporal Exposure: Dissolved Selenium, Conductivity, Sulfate, and Temperature ................59

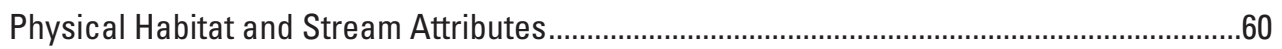

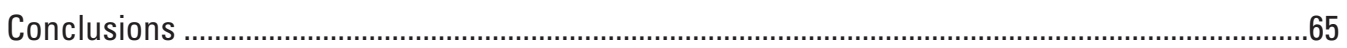

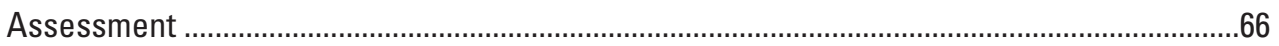

Site-Specific Model Development and Validation .................................................................67

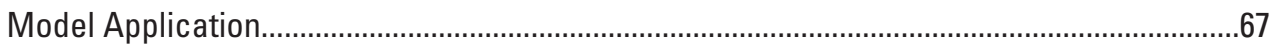

Linkage to Fish Species Abundance and Richness ........................................................69

Model Refinements and Reduction in Uncertainty ...........................................................69

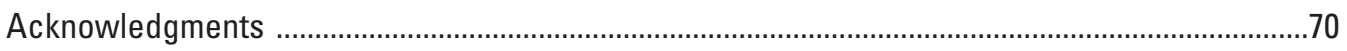

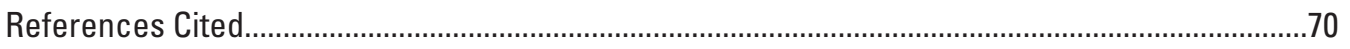

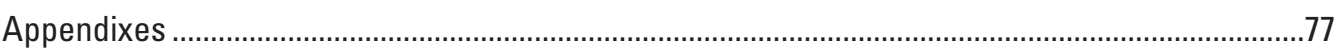

Appendix 1. Site Locational Information and Detailed Chemical Data for Field Sites

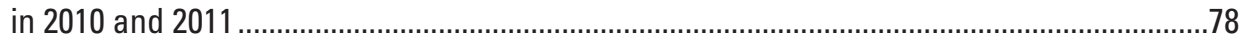

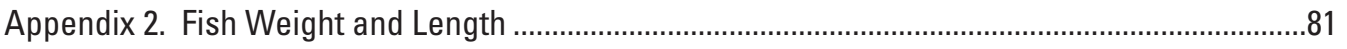

\section{Figures}

1. Graph showing valley-fill inventory and acreage in southern West Virginia over the time period 1984-2009.

2. Bar graph of water-column Se concentrations in unmined, mined without valley fill, and mined with valley fill categories of streams within southern West Virginia basins. ............4

3. Bar graph of Se concentrations in fish for 1997-1998 categorized by fish collection in streams (1) within HUC8s with the majority of permitted mines and (2) within the reminder of HUC8s sampled.

4. Map of West Virginia with county boundaries showing locations of USGS 2010-2011 sampling sites and Plum Orchard Lake, a state designated reference site ..........................

5. Schematic diagram of the mountaintop coal mining process and valley fill landscape.........9

6. Diagram of the components and equations for ecosystem-scale Se modeling that

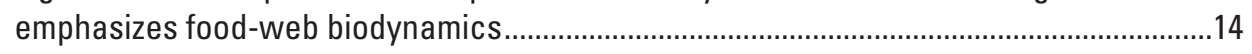

7. Graph showing water-column Se concentrations at different times for the Mud River.......16

8. Concentrations of Se in food webs (2004-2008) for the Upper Mud River Reservoir and Plum Orchard Lake.

9. Bar graphs showing Se concentrations in fish for river segments and tributaries of the Upper Mud River basin ....

10. Bar graphs showing Se concentrations in fish for $(A)$ Beech Creek and White Oak Creek, $(B)$ Jacks Branch mine drainage, and $(C)$ Conner Run and Little Scary Creek.......20

11. Schematic map of USGS sampling sites and compiled Se data for the Upper Mud River Basin Ecosystem I during 2010-2011..

12. Schematic map and compiled Se from various studies for the Upper Mud River Basin Ecosystem II.

13. Schematic map of USGS sampling sites and compiled Se data for the Clear Fork Basin Ecosystem during 2010-2011 
14. Schematic map of USGS sampling sites and compiled Se data for the Twentymile Creek Basin Ecosystem during 2010-2011.

15. Schematic map of USGS sampling sites and compiled Se data for Beech Creek, Cabin Creek, and the Birch River during 2010-2011..

16. Bar graphs showing assessed Se concentrations within the progression of dissolved, suspended particulate material, invertebrate, and fish for USGS sites sampled in the Upper Mud River basin in 2010 and 2011. MRLO, Mud River lower; MRUP, Mud River upper; MRLF, left fork Mud River; MRUB, Upton Branch.

17. Bar graphs showing assessed Se concentrations within the progression of dissolved, suspended particulate material, invertebrate, and fish for USGS sites sampled in the Clear Fork basin in 2010 and 2011

18. Bar graphs showing assessed Se concentrations within the progression of dissolved, suspended particulate material, invertebrate, and fish for USGS sites sampled in the Twentymile Creek basin in 2010 and 2011

19. Bar graphs showing assessed Se concentrations within the progression of dissolved, suspended particulate material, invertebrate, and fish for USGS sites for Cabin Creek (CACR), Beech Creek (BECR), and the Birch River (BIRI) in 2011

20. Bar graphs showing comparison of Se concentrations in fish for USGS sites sampled during fall 2010, spring 2010, and spring 2011

21. Time-series graphs of dissolved Se concentrations, conductivity, sulfate concentrations, and temperature for USGS sites sampled during 2010 and 2011

22. A conceptual ecosystem-scale Se model as applied to the mountaintop mining and valley-fill regions of southern West Virginia.

23. Graphs showing linear regression and correlation of observed Se concentrations in aquatic insects and those concentrations predicted through ecosystem-scale modeling from observed particulate concentrations...

24. Graph showing linear regression and correlation of observed Se concentrations in fish and concentrations and those concentrations predicted through ecosystemscale modeling from observed particulate concentrations and the previously predicted invertebrate Se concentrations.

25. Schematic representation of model application for streams illustrating site-specific Kds and predicted dissolved Se concentrations derived by using a fish-tissue guideline of $7.9 \mu \mathrm{g} / \mathrm{g}(\mathrm{wb} \mathrm{dw})$ for the base-case scenario of suspended particulate material to aquatic insect to creek chub

26. Schematic representation of model application for streams illustrating site-specific Kds and predicted dissolved Se concentrations derived by using a fish-tissue guideline of $7.9 \mu \mathrm{g} / \mathrm{g}(\mathrm{wb} \mathrm{dw})$ for the base-case scenario of suspended particulate material to aquatic insect to creek chub

27. Schematic representation of model application for streams illustrating site-specific $K_{d} s$ and predicted dissolved Se concentrations derived by using a fish-tissue guideline of 5.0 $\mu \mathrm{g} / \mathrm{g}(\mathrm{wb} \mathrm{dw})$ for the base-case scenario of suspended particulate material to aquatic insect to creek chub

28. Schematic representation of model application for streams illustrating site-specific $K_{d} s$ and predicted dissolved Se concentrations derived by using a fish-tissue guideline of $5.0 \mu \mathrm{g} / \mathrm{g} \mathrm{wb} \mathrm{dw}$ for the base-case scenario of suspended particulate material to aquatic insect to creek chub

29. Bar graphs and boxplots showing variation in stream parameters measured at USGS sites in southern West Virginia during 2010.

30. Boxplots showing variation of physical habitat parameters measured at USGS sites in southern West Virginia during 2010. 


\section{Tables}

1. Fish species collected from streams in mountaintop mining areas of West Virginia and Kentucky, with fish characteristics also given................................................... 6

2. Study area watersheds, basins, and sites .......................................................... 9

3. Field sites and dates of sampling in 2011 for each type of data used in comparative assessment, modeling, and validation

4. Modeling and validation showing observed and predicted Se concentrations for invertebrates.

5. Modeling and validation showing observed and predicted Se concentrations for fish ...40

6. Dissolved and suspended-particulate-material Se concentrations and Se speciation data as a basis for preliminary calculation of environmental partitioning factors $\left(\mathrm{K}_{\mathrm{d}} \mathrm{s}\right)$ for June 2008, February-March 2011, and June 2011.

7. Foodweb Se concentrations (observed and predicted) for sites not included in regulatory translation discussion (low environmental Se: dissolved $<1 \mu \mathrm{g} / \mathrm{L}$ and mean fish $<3.2 \mu \mathrm{g} / \mathrm{g}$ wb $\mathrm{dw}$ )

8. Site-specific exposure scenarios: regulatory fish-tissue Se target of $7.9 \mu \mathrm{g} / \mathrm{g}$ (wb, dw) to dissolved Se concentrations specific to June 2008 and June 2011 hydrologic conditions.

9. Site-specific exposure scenarios: regulatory fish-tissue Se target of $7.9 \mu \mathrm{g} / \mathrm{g}$ (wb, dw) to dissolved Se concentrations specific to February-March 2011 hydrologic conditions.

10. Site-specific exposure scenarios: regulatory fish-tissue Se target of $5.0 \mu \mathrm{g} / \mathrm{g}$ (wb, dw) to dissolved Se concentrations specific to June 2008 and June 2011 hydrologic conditions.

11. Site-specific exposure scenarios: regulatory fish-tissue Se target of $5.0 \mu \mathrm{g} / \mathrm{g}$ (wb, dw) to dissolved Se concentrations specific to February-March 2011 hydrologic conditions

12. Fish community data by site including species richness and abundance, with estimated stream order also given.

13. Fish abundance by species for all sites and sampling periods..........................................60

14. Fish species and their abundance by site and sampling date............................................62

15. Number of darter species (benthic insectivores) present, species abundance, and number of sampling visits during monitoring in 2010 and 2011.

16. Selenium concentrations in reproductive tissue (ovary) of fish collected during 2010 and 2011

17. Estimated median discharges for streams sampled in 2010 and 2011 ..............................65

A1.1. Site locational detail for sample collection in southern West Virginia ................................78

A1.2. Temperature and field measured water-quality data for 2010 and 2011 ............................79

A1.3. Dissolved water-quality data for 2010 and 2011 ..................................................................80

A2.1. Fish weight, standard length, total length, and percent moisture for whole-body samples analyzed for Se concentrations in 2010 and 2011

A2.2. Fish weight, standard length, and total length for ovary samples analyzed for Se concentrations in 2010 and 2011 


\title{
Selenium in Ecosystems within the Mountaintop Coal Mining and Valley-Fill Region of Southern West Virginia- Assessment and Ecosystem-Scale Modeling
}

\author{
By Theresa S. Presser
}

\section{Abstract}

Coal and associated waste rock are among environmental selenium (Se) sources that have the potential to affect reproduction in fish and aquatic birds. Ecosystems of southern West Virginia that are affected by drainage from mountaintop coal mines and valleys filled with waste rock in the Coal, Gauley, and Lower Guyandotte watersheds were assessed during 2010 and 2011. Sampling data from earlier studies in these watersheds (for example, Upper Mud River Reservoir) and other mining-affected watersheds also are included to assess additional hydrologic settings and food webs for comparison. Basin schematics give a comprehensive view of sampled species and Se concentration data specific to location and date. Food-web diagrams document the progression of Se trophic transfer across suspended particulate material, invertebrates, and fish for each site to serve as the basis for developing an ecosystem-scale model to predict Se exposure within the hydrologic conditions and food webs of southern West Virginia. This approach integrates a site-specific predator's dietary exposure pathway into modeling to ensure an adequate link to $\mathrm{Se}$ toxicity and, thus, to species vulnerability.

Site-specific fish abundance and richness data in streams documented various species of chub, shiner, dace, darters, bass, minnow, sunfish, sucker, catfish, and central stoneroller (Campostoma anomalum), mottled sculpin (Cottus bairdii), and least brook lamprey (Lampetra aepyptera). However, Se assessment species for streams, and hence, model species for streams, were limited to creek chub (Semotilus atromaculatus) and central stoneroller. Both of these species of fish are generally considered to have a high tolerance for environmental stress based on traditional comparative fish community assessment, with creek chub being present at all sites. Aquatic insects (mayfly, caddisfly, stonefly, dobsonfly, chironomid) were the main invertebrates sampled in streams. Collection of suspended particulate material acted as an integrator of organicrich, fine-grained biomass present in streams.

The base-case food web modeled for streams was suspended particulate material to aquatic insect to creek chub, with comparative modeling of a direct particulate-to-stoneroller food web. Model species for a reservoir setting were based on an earlier study of bluegill sunfish (Lepomis macrochirus), green sunfish (Lepomis cyanellus), and largemouth bass (Micropterus salmoides). Several reservoir food webs were considered based on a variety of invertebrates (insect, snail, clam). For stream and reservoir settings, predicted Se concentrations in exposure scenarios showed a high degree of correlation $\left(r^{2}=0.91\right.$ for invertebrates and 0.75 for fish) with field observations of Se concentrations when modeling was initiated from suspendedparticulate-material Se concentrations and model transfer parameters defined previously in the literature were used. These strong correlations validate the derived site-specific model and establish sufficient confidence that the predictions from the developed model can be quantitatively applied to the ecosystems in southern West Virginia.

An application of modeling used a metric describing the partitioning of Se between particulate material and dissolved phases $\left(K_{d}\right)$ to allow determination of a dissolved Se concentration that would be necessary to attain a site-specific Se fish body burden. The operationally defined $\mathrm{K}_{\mathrm{d}}$ quantifies the complex process of transformation at the base of a food web on a sitespecific basis. The magnitude of this metric is known to vary with such factors as Se speciation, particulate-material type, and hydrology. This application (1) ties dissolved Se concentrations to fish tissue concentrations; (2) allows consideration of different choices for intervening site-specific exposure steps that set Se bioaccumulation, partitioning, and bioavailability; and (3) generates implications for management decisions that define protection through different regulatory pathways and guidelines. The range of model outcomes accounts for critical sources of variability and establishes whether site and foodweb characterization were adequate to represent the dynamics of the system with certainty. This is especially true in terms of particulate-material phases at the base of the food web and utilization of $\mathrm{K}_{\mathrm{d}}$ in different hydrologic settings. For streams, a range of field-derived $\mathrm{K}_{\mathrm{d}} \mathrm{s}$ were applied to food-web exposure scenarios within a framework of locational and hydrologic variables (area of stream basin; stream gradient and discharge) that may affect the magnitude of $\mathrm{K}_{\mathrm{d}}$. Overlaying even a coarse temporal scale that acknowledges variability in stream dissolved Se and Se speciation, such as through seasonal derivation of $\mathrm{K}_{\mathrm{d}}$, can substantially narrow model uncertainty.

Modeling that constrains the place and time of greatest ecosystem Se sensitivity within a specified food web gives insight into Se risk and identifies controlling management 
Selenium in Ecosystems within the Mountaintop Coal Mining and Valley-Fill Region of Southern West Virginia

alternatives within a watershed or stream basin. If there is a range of hydrologic settings, specificity is needed to establish a hierarchy of in-stream and off-stream habitats for a watershed approach that takes into account Se-enriched water moving through different $\mathrm{K}_{\mathrm{d}}$ and food web environments. If there is a range of predator vulnerabilities (measured as a combination of food-web Se biodynamics and response in Se toxicity tests) within the site-specific community of fish species to be protected, then choice of fish species is critical to protection because it determines the food web and, hence, the magnitude of biotransfer through which Se is modeled. Whether creek chub is representative of the vulnerability to Se of all fish species encountered within the study-site ecosystems will require additional species-specific data and analysis. A range of site-specific scenarios illustrated here set model outcomes, but the final quantitative evaluation of alternatives and their implications will be those generated through choices and guidance formulated by state and other agencies in their decisionmaking processes.

Proposed additions and refinements to the ecosystemscale site-specific approach developed here include consideration of:

- measurement of temporally matched pairs of dissolved and suspended-particulate-material Se concentrations across a broader range of stream sites to expand the stream $K_{d}$ database and to test the representativeness of a suspended-particulate-material sample within a stream;

- characterization of different phases of particulate material across seasons to better define the base of the food web and connect to invertebrate feeding;

- refinement of model assumptions concerning dietary preferences and composition for fish to develop additional trophic transfer factors (TTFs) (for example, calculation of $\mathrm{TTF}_{\text {invertebrate composite }}$ for mixed diets);

- expansion of modeling of fish species and their food webs to include Se-vulnerable species;

- temporal characterization of a predator's life cycle and habitat use as additional model layers to integrate with Se biodynamics in streams;

- investigation of the effect of stream gradient on $\mathrm{K}_{\mathrm{d}}$ based on a finer scale than presented here in terms of such variables as residence time, watershed dilution, and physical habitat attributes (for example, amount of ponding versus run or riffle within a stream); and

- linkage to discharge through use of stream gaging to record variability and enable model organization within water-year types and discharge seasons.

Investigating the presence and variability of prey and predator species in demographically open systems such as streams also is key to model outcomes given the overall environmental stressors (for example, general landscape change, food-web disruption, recolonization potential) imposed on the composition of biological communities in coal mining and valley-fill affected watersheds.

\section{Introduction}

Selenium is recognized as an important contaminant in aquatic environments because of its potency as a reproductive toxin and its ability to bioaccumulate through food webs (Chapman and others, 2010; Presser and Luoma, 2010a). Selenium's role is well documented in local extinctions of fish populations (Lemly, 2002) and occurrences of deformities of aquatic birds in affected habitats (Skorupa, 1998). Specifically for Se in aquatic ecosystems: (1) water-column Se has proven to be an imprecise predictor of Se bioaccumulated in food webs because dietary Se makes up 95 percent of tissue Se in invertebrates and fish; (2) site-specific biogeochemical transformation of dissolved Se into particulate forms (algae, microbes, seston, or sediments) determines the concentration of Se available at the base of food webs; (3) a 38-fold variability in trophic transfer of particulate-material Se to invertebrate species is mainly driven by physiological differences in assimilation efficiency and the rate constant of loss of Se among invertebrates species; and (4) dietary transfer of invertebrate Se to fish species (as measured in whole-body tissue) has a median of approximately 1 , which reflects preservation of Se as it passes up food webs but with little increase over the trophic level below (Luoma and Presser, 2009; Presser and Luoma, 2010a; Chapman and others, 2010). Less information is available concerning dietary Se biodynamics of aquatic birds, but a bird species' dietary choice of prey and the bioaccumulation kinetics of that prey are still fundamental to their exposure (as measured in bird eggs) (Skorupa, 1998; Presser and Luoma, 2010a). Overall, this differential response to Se makes some predator species more vulnerable and, thus, more likely to experience demographic collapse from moderately contaminated environments than others (Lemly, 2002; Stewart and others, 2004; Luoma and Presser, 2009).

As of 2010, the U.S. Environmental Protection Agency (USEPA) has under consideration a national whole-body fish-tissue Se criterion (USEPA, 2004). In general, a tissue Se criterion would help fill the need to connect effects from a predator's dietary Se exposure pathway into a regulatory strategy (Reiley and others, 2003). However, implementation of a fish-tissue criterion would require translation to a water-column Se concentration to satisfy other regulatory requirements, such as permit and load limits.

This report demonstrates a step-by-step methodology that quantitatively addresses dietary Se biodynamics in food webs within the ecosystems of southern West Virginia affected by mountaintop coal mining and valley fills. The combined mechanistic and empirically based approach evaluates how interactions of a system's ecology, biochemistry, and hydrology and a species' physiology and ecotoxicology affect ecological Se risk at any given location. Ecosystemscale Se modeling, the approach used here, was developed to conceptualize and quantify the current state of knowledge concerning the dietary transfer of Se through ecosystems and, thus, was able to formalize the knowledge necessary to understand the basis of protective criteria for Se (Luoma and Presser, 2009; Presser and Luoma, 2010a). Because 
this approach links Se concentrations across media (water, particulate material, invertebrate, and fish) it can serve as a methodology for implementing a tissue criterion. The initial basis for the methodology used data from a set of common aquatic settings and food webs to illustrate that environmentally safe dissolved Se concentrations will differ among ecosystems depending on the biogeochemical conditions and ecological pathways in those systems. Thus, implementation of a fish tissue Se criterion needed to be both site-specific in terms of Se partitioning and bioavailability and species-specific in terms of prey and predator to account for differential bioaccumulation among food webs.

Analysis and development of a site-specific ecosystemscale Se model for the watersheds of southern West Virginia affected by mountaintop coal mining and valleys fills is based on site-specific data collected in field studies within the Upper Mud River, Clear Fork, and Twentymile Creek basins during 2010 and 2011. Five additional sites (White Oak Creek, Seng Creek, Cabin Creek, Beech Creek, and Birch River) were selected for one-time assessment in 2011. Monitoring included Se concentrations in water, suspended particulate material, invertebrate, and fish, all of which are essential inputs for illustrating, quantifying, and modeling the pathways, biotransfer, and bioaccumulation of Se through the environment. Relevant Se data from other recent studies also were compiled and discussed to widen the context of the study here. Consideration of the potential degradation of the composition of biological communities in these ecosystems that are perturbed by the general environmental stresses of mountaintop coal mining and valley fills is in contrast to quantifying the effects of Se on specific predator species afforded by ecosystem-scale Se modeling.

Specifically, this report presents (1) field assessment results and analysis across basin ecosystems affected by coal mining and valley fills; (2) site-specific conceptual models for stream and reservoir ecosystems that define sites in the terms of an ecosystemscale Se approach; (3) the fundamentals of the relations that serve as the basis of modeling; (4) a range of model parameters and guidelines to test model sensitivity; (5) quantification of the potential of each ecosystem for Se bioaccumulation; (6) comparison of predicted Se concentrations to modeled Se concentrations (that is, validation); and (7) an application of ecosystem-scale modeling that translates an assumed regulatory Se target for fish to a dissolved Se concentration under a set of exposure scenarios for the sampled basins.

Model application for streams considered additional variables (for example, area of stream basin; stream gradient and discharge; seasonal patterns of Se source dynamics) to help categorize hydrologic settings. Measured fish-community composition and traditional physical habitat parameters (for example, percentages of cascade, pool, riffle, and run in streams; or percentages of clay, sand, gravel, cobble, boulder, and bedrock in stream beds) connect to both traditional measures of the biotic integrity of a stream (for example, Karr, 1981) and recent assessment metrics concerning the ecological structure and function of high-gradient streams (U.S. Army Corps of Engineers, 2010).

\section{Site-Specific Setting, Sources, and Background}

Large-scale land disturbance is associated with mountaintop coal mining and waste-rock management in the southern and central Appalachian Mountains. Tops of mountain ridges are sheared off as near-surface, thin-layered coals are mined, and adjacent valleys are filled with waste rock (valley fills). The four Appalachian states of West Virginia, Kentucky, Virginia, and Tennessee are the most affected. For these states during the period 1985-1999, a total of 75,072 acres of land was covered by 5,858 valley fills (USEPA, 2005). A more recent analysis in terms of impacts to West Virginia by the summer of 2009 showed 1,812 valley fills and 270 refuse fills covering an area of 56,780 acres (fig. 1) and affecting 700 miles of intermittent and perennial stream (Shank, 2010). The progression of fill construction for the period 1984-2009 was approximately linear in terms of cumulative area, but exhibiting a 7.5-fold increase overall (Shank, 2010). Griffith and others (2012) suggested that a similar series of coal and noncoal (that is, overburden removed by mountaintop mining) formations and weathering reactions in the central Appalachians results in (1) rather narrowly defined strata conducive to surface mining; (2) a common mixture of overburden components; and (3) a relatively consistent major-ion chemical composition in valley-fill effluent.

Coal seams and their associated waste rock are primary geologic Se sources associated with sedimentary deposits enriched in organic material (Presser and others, 2004a; Young and others, 2010). For five surface coal mining basins in West Virginia, Bryant and Childers (2002) showed that the leaching of Se into streams below valley fills was greater than that into streams of nonmined areas or of mined areas without fills (fig. 2). The current $5 \mu \mathrm{g} / \mathrm{L}$ water-quality Se criterion for protection of aquatic life (USEPA, 1987) was shown to be exceeded in mine discharges (reported by the West Virginia Department of Environmental Protection; WVDEP, 2006) and in streams of basins (Bryant and Childers, 2002; WVDEP, $2009,2010)$ in the primary region of mountaintop coal mining with valley fills in West Virginia (Shank, 2003, 2004, 2010) (for example, fig. 2). Holding or sedimentation ponds required at the base of valley fills were found to contain the highest $\mathrm{Se}$ concentrations in the systems studied (24-42 $\mu \mathrm{g} / \mathrm{L}$ ) (Bryant and Childers, 2002) (fig. 2). A more recent analysis of a toe pond for the Connelly Branch of the Upper Mud River showed a Se concentration of $16.9 \mu \mathrm{g} / \mathrm{L}$ (WVDEP, 2009). In 2010, sampling of the Upper Mud River basin found a linear correlation between water-column concentrations of contaminants, including Se, and the proportion of the contributing watershed dedicated to surface coal mines (Lindberg and others, 2011).

The mechanism of Se mobilization within the environment depends on the exposure of waste rock (shales, mudstones, and sandstones) during mining and its subsequent storage in valley fills. Waste rock is usually generated at a rate greater than that of mined material. Hydrologically, valley fills can act as conduits of flow, similar to cross-valley fills 
in areas of phosphate mining (Presser and others, 2004b). Waste-rock shale Se data are limited, but both shales and coals were enriched in Se in samples from contiguous depths, with carbonaceous materials (that is, carboliths) showing the greatest enrichment (Jenkins and Schaer, 2005; Roy, 2005). Valley fills provide a reservoir of reduced Se (relatively insoluble selenide and elemental Se in host rocks) that is oxidized to mobile selenate over time. Waste leachate Se concentrations have been found to be related to the overall magnitude of the Se reservoir available for release over time (Presser and others, 2004a,b). Additionally, alkaline conditions (in surrounding strata and aquifers or introduced) can neutralize traditional acid mine drainage (Caruccio and others, 1977; Griffith and others, 2012) and in the process speed Se mobility (Presser and others, 2004a). All of these factors result in Se being transported regionally within watershed systems and potentially bioaccumulating in aquatic food webs (Paybins and others, 2000; Chambers and Messinger, 2001;
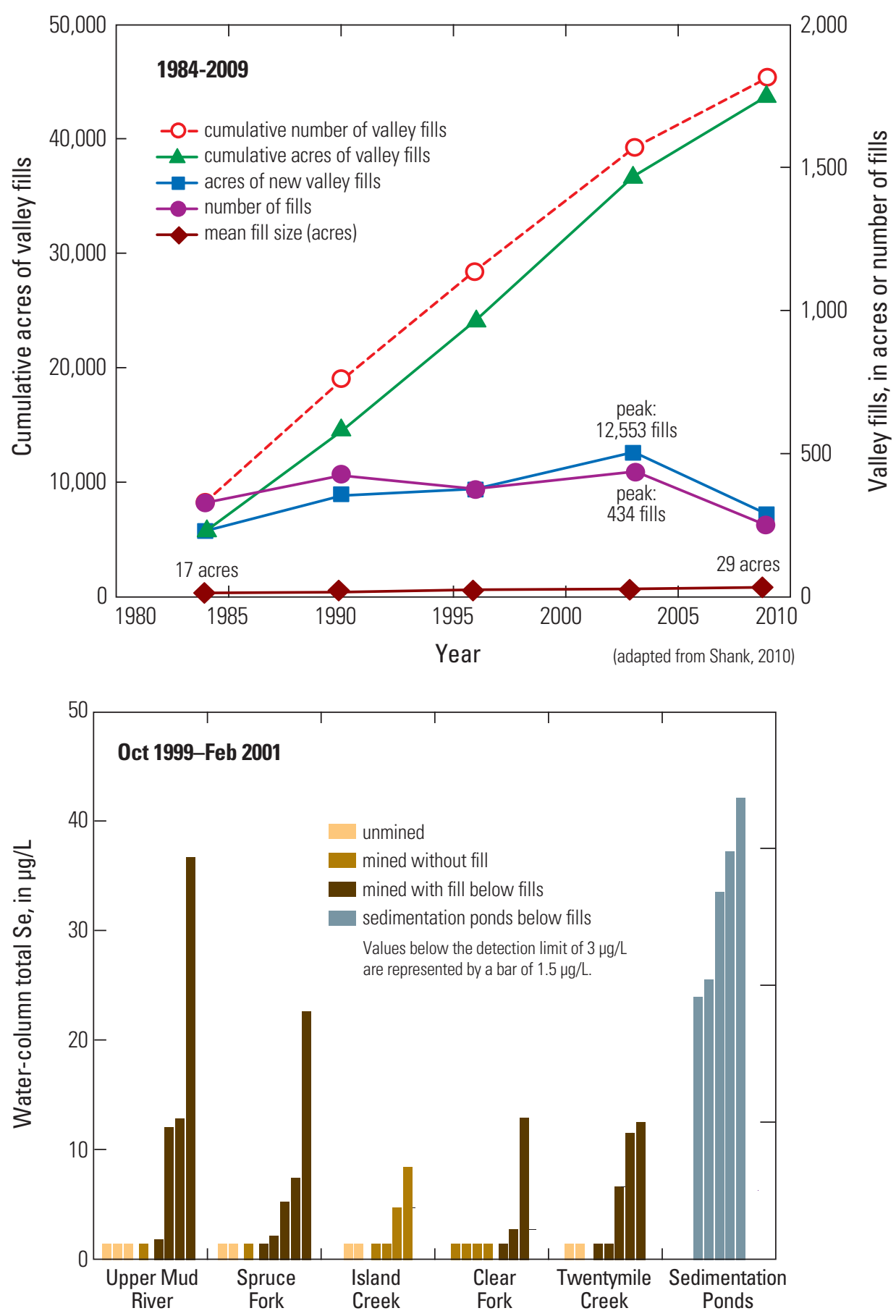

(Bryant and Childers, 2002)
Figure 1. Graph showing valleyfill inventory and acreage in southern West Virginia over the time period 1984-2009.

Figure 2. Bar graph of watercolumn Se concentrations in unmined, mined without valley fill, and mined with valley fill categories of streams within southern West Virginia basins. 
USEPA, 2003, 2005, 2011a,b; Patnode and others, 2005; Meyer and others, 2007; Palmer and others, 2010; Lindberg and others, 2011; Bernhardt and others, 2012).

Fish species common to the streams of West Virginia include members of the Percidae (darters), Centrarchidae (sunfish, bass), Cyprinidae (minnow, shiner, chub, stoneroller, dace), Cottidae (sculpin), and Catostomidae (sucker) families (table 1) (Stauffer and Ferreri, 2002). Sport-fishing species in the Upper Mud River Reservoir include largemouth bass, bluegill sunfish, channel catfish (Ictalurus punctatus), crappie (Pomoxis), and muskellunge (Esox masquinongy). The muskellunge is considered an apex predator. Rainbow trout and brown trout were noted by Stauffer and Ferreri (2002) as introduced species. The diamond darter (Crystallaria cincotta), a fish native to West Virginia, recently was listed as an endangered species (USFWS, 2012a, 2013). The fish species' characteristics listed in table 1 enable broad comparisons among species, but this compilation is not meant to be exhaustive. For example, primary diet categories (mainly specific to fish found in West Virginia and Kentucky; Stauffer and Ferreri, 2002) are not quantitatively defined and may be variable across source studies (see, for example, www. fishbase.org/search.php).

Fewer fish species, including benthic insectivore species such as darters, were found in streams affected by valley fills within the Upper Mud River basin than in streams in unmined areas within the Big Ugly Creek basin during fall 2001 (Stauffer and Ferreri, 2002). Additional variables that may affect comparison of fish assemblages between these two categories included stream order, physical habitat type, and flow condition (varying between seasons or drought) (Stauffer and Ferreri, 2002). Elevated conductivity was a signature of the valley-fill sites (Bryant and Childers, 2002; Pond and others, 2008; Bernhardt and others, 2012; Griffith and others, 2012), along with general landscape change and food web disruption. Concern here was for a reduction in macroinvertebrate communities, such as mayfly (Ephemeroptera) taxa, that was occurring below mines with valley fills (Paybins and others, 2000; Fulk and others, 2003; Hartman and others, 2005; Pond and others, 2008; Pond, 2010; USEPA, 2011a,b). Impacts were thought to develop as an upward flow from lower to higher trophic levels that initiates from lack of food at the base of food webs (USEPA, 2011a,b).

During 1997-1998, fish tissue Se concentrations were higher within hydrologic regions of West Virginia that included the majority of permitted coal mines and valley fills (that is, Coal, Gauley, Upper Guyadotte, Lower Guyadotte, Twelvepole, Tug Fork, Elk, and Upper Kanawha) than in nonmining hydrologic regions (USEPA, 1997-1998) (fig. 3). These compiled historical Se data show a generalized condition, but not the ecosystem specifics or Se concentrations that contributed to that condition. Species, flow, stream order, water quality, and timing were among the variables that differed across these two categories (USEPA, 1997-1998). Sampling was done (1) mainly during July and August of 1997 and 1998; (2) at streams varying in stream order from 1 to 8 ; and (3) with a fish species commonality of nine within the two categories (fig. 3).

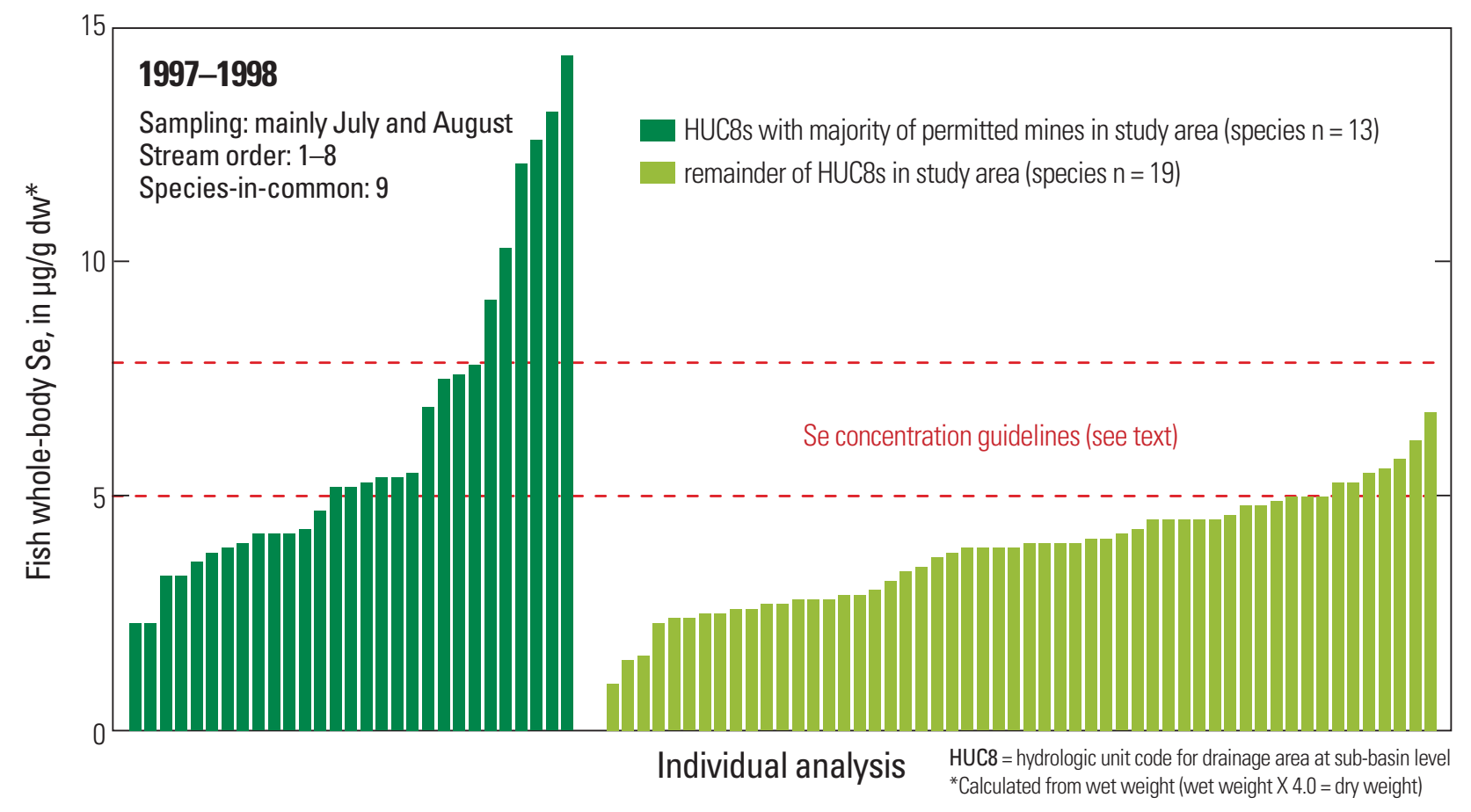

Figure 3. Bar graph of Se concentrations in fish for 1997-1998 categorized by fish collection in streams (1) within HUC8s (hydrologic unit code for drainage areas at subbasin level) with the majority of permitted mines and (2) within the remainder of HUC8s sampled. Data is from the U.S. Environmental Protection Agency Environmental Monitoring and Assessment Program (EMAP). 
Table 1. Fish species collected from streams in mountaintop mining areas of West Virginia and Kentucky, with fish characteristics also given. [Adapted from Stauffer and Ferreri, 2002; size and age data from http://www.fishbase.org/search.php; * additions to list, see text]

\begin{tabular}{|c|c|c|c|c|c|}
\hline Common name & Scientific name & Primary diet & Traits & $\begin{array}{c}\text { Common size } \\
\text { (maximum) mm }\end{array}$ & $\begin{array}{c}\text { Maximum } \\
\text { age year. }\end{array}$ \\
\hline central stoneroller & Campostoma anomalum & herbivore & & $187(220)$ & $6(?)$ \\
\hline least brook lamprey & Lampetra aepyptera & herbivore & headwater & $121(180)$ & 8 \\
\hline southern redbelly dace & Phoxinus erythrogaster & herbivore & headwater, lithophil & $58(91)$ & 3 \\
\hline arrow darter & Etheostoma sagitta & benthic insectivore & & 120 & \\
\hline banded darter & Etheostoma zonale & benthic insectivore & lithophil & $53(78)$ & 4 \\
\hline blackside darter & Percina maculata & benthic insectivore & lithophil & $58(110)$ & 4 \\
\hline diamond darter* & Crystallaria cincotta & benthic insectivore & & 77 & \\
\hline emerald darter & Etheostoma baileyi & benthic insectivore & lithophil & 56 & \\
\hline fantail darter & Etheostoma flabellare & benthic insectivore & headwater & $52(84)$ & 4 \\
\hline greenside darter & Etheostoma blennioides & benthic insectivore & lithophil & $55(170)$ & 5 \\
\hline johnny darter & Etheostoma nigrum & benthic insectivore & pioneering & $39(72)$ & 4 \\
\hline logperch darter & Percina caprodes & benthic insectivore & lithophil & $125(180)$ & 3 \\
\hline rainbow darter & Etheostoma caeruleum & benthic insectivore & lithophil & $53(77)$ & 3 \\
\hline stripetail darter & Etheostoma kennicotti & benthic insectivore & & $49(83)$ & 3 \\
\hline variegate darter & Etheostoma variatum & benthic insectivore & lithophil & 110 & 4 \\
\hline brindled madtom & Noturus miurus & benthic insectivore & & $73(130)$ & 3 \\
\hline mottled sculpin & Cottus bairdii & benthic insectivore & headwater & $84(150)$ & 2 \\
\hline river chub & Nocomis micropogon & insectivore & & $135(330)$ & 5 \\
\hline mimic shiner & Notropis volucellus & insectivore & & $57(76)$ & 2 \\
\hline rosefin shiner & Lythrurus ardens & insectivore & & $58(90)$ & \\
\hline rosyface shiner & Notropis rubellus & insectivore & lithophil & $67(90)$ & 3 \\
\hline sand shiner & Notropis ludibundus & insectivore & & $44(82)$ & 3 \\
\hline silver shiner & Notropis photogenis & insectivore & lithophil & $89(140)$ & \\
\hline spotfin shiner & Cyprinella spiloptera & insectivore & & $77(120)$ & 5 \\
\hline striped shiner & Luxilus chrysocephalus & insectivore & lithophil & $83(240)$ & 4 \\
\hline bluegill sunfish & Lepomis macrochirus & insectivore & & $190(410)$ & 10 \\
\hline green sunfish & Lepomis cyanellus & insectivore & pioneering & $200(310)$ & 9 \\
\hline longear sunfish & Lepomis megalotis & insectivore & & $115(240)$ & 6 \\
\hline redbreast sunfish & Lepomis auritus & insectivore & & $108(305)$ & \\
\hline golden redhorse & Moxostoma erythrurum & insectivore & lithophil & $288(780)$ & 11 \\
\hline northern hog sucker & Hypentelium nigricans & insectivore & lithophil & $298(610)$ & \\
\hline yellow bullhead & Ameiurus natalis & insectivore & & $225(470)$ & 4 \\
\hline rosyside dace & Clinostomus funduloides & insectivore & headwater, lithophil & $67(115)$ & \\
\hline longnose dace & Rhinichthys cataractae & insectivore & & $94(225)$ & 5 \\
\hline silverjaw minnow & Ericymba buccata & insectivore & pioneering & $38(98)$ & 3 \\
\hline pumpkinseed sunfish & Lepomis gibbosus & molluscivore & & $99(400)$ & 12 \\
\hline redear sunfish* & Lepomis microlophus & molluscivore & & $192(432)$ & 7 \\
\hline creek chub & Semotilus atromaculatus & omnivore & pioneering & $191(303)$ & 8 \\
\hline bluntnose minnow & Pimephales notatus & omnivore & pioneering & $65(110)$ & 5 \\
\hline fathead minnow & Pimephales promelas & omnivore & pioneering & $73(101)$ & 5 \\
\hline white sucker & Catostomus commersoni & omnivore & lithophil & $407(650)$ & 12 \\
\hline channel catfish* & Ictalurus punctatus & omnivore & & $570(1320)$ & 24 \\
\hline common carp & Cyprinus carpio & omnivore & & $310(1100)$ & 38 \\
\hline blacknose dace & Rhinichthys atratulus & omnivore & headwater, lithophil & $57(124)$ & 3 \\
\hline black bullhead & Ameiurus melas & omnivore & & $266(660)$ & 10 \\
\hline brown bullhead & Ameiurus nebulosus & omnivore & & $250(550)$ & 9 \\
\hline black crappie & Pomoxis nigromaculatus & omnivore & & $275(490)$ & 15 \\
\hline brook silverside & Labidesthes sicculus & omnivore & & $84(130)$ & 2 \\
\hline red shiner & Cyprinella lutrensis & omnivore & & $49(90)$ & 3 \\
\hline largemouth bass & Micropterus salmoides & piscivore & & $400(970)$ & 23 \\
\hline rock bass & Ambloplites rupestris & piscivore & & $154(430)$ & 18 \\
\hline smallmouth bass & Micropterus dolomieu & piscivore & & $80(690)$ & 26 \\
\hline spotted bass & Micropterus punctulatus & piscivore & & $300(635)$ & 7 \\
\hline white crappie & Pomoxis annularis & piscivore & & $250(530)$ & 10 \\
\hline muskellunge* & Esox masquinongy & apex predator & & $950(1830)$ & 30 \\
\hline
\end{tabular}


An analysis for the Upper Mud River basin also compared the number of fish species (total or darter) in stream sites affected by valley fills with Se (sites with dissolved Se concentrations of 9.5-31.5 $\mu \mathrm{g} / \mathrm{L}$ ) to those without Se (sites with dissolved Se concentrations less than the detection limit of $3 \mu \mathrm{g} / \mathrm{L}$ ) (Stauffer and Ferreri, 2002). The number of sites for comparison was small (five sites with Se; three sites without Se). The study showed for total number of species that the median number of species (8) was the same at sites with or without $S e$, but the range of species at sites with Se (2-12) was lower than the range of species without Se (6-18). For darter species, the maximum number of species (4) was the same in both cases, but three sites with Se yielded no darter species.

Elevated whole-body tissue Se concentrations in plethodontid salamanders ( $14.3 \mu \mathrm{g} / \mathrm{g}$ dry weight maximum) occurred in headwater stream sites associated with valley fills when compared to reference sites or sites affected by air emission Se sources (Patnode and others, 2005). Twenty-seven species of this family of lungless salamanders (for example, Appalachian seal salamander, Desmognathus monticola; northern dusky salamander, $D$. fuscus) inhabit West Virginia's seeps, brooks, and small steams, with Se concentrations reflecting a variety of habitats, obligate aquatic phases, and dietary preferences (Patnode and others, 2005). Reduction in salamander assemblages also occurred at sites with elevated Se concentrations in salamanders, but other factors than Se, such as depressed macroinvertebrate fauna and bed substrate composition, may be affecting headwater biota (Patnode and others, 2005). Thus, headwater plethodontid salamander species are potential predators to assess for Se in headwater streams where traditional fish species assemblages are poorly developed or absent (Patnode and others, 2005).

The Upper Mud River basin within the Guyandotte watershed lies downstream from one of the largest mountaintop removal and valley fill operations in the United States and is affected by permitted seleniferous effluents. The Hobet Mining Complex includes the Hobet 21 Mine, which has increased in size to more than 10,000 acres over a 28-year period (1984 to 2012; http://earthobservatory.nasa. gov/Features/WorldOfChange/hobet.php). The Upper Mud River Reservoir, a 306-acre impoundment created in 1995 at the confluence of the main forks of the river, recently came under scrutiny because of the occurrence of deformities indicative of Se toxicity in larval bluegill sunfish (Lepomis macrochirus) and adult largemouth bass (Micropterus salmoides) (WVDEP, 2010). Bluegill larval deformity rates of $12.3,50$, and 13.8 percent were measured in the reservoir in 2007, 2008, and 2009, respectively, with a 20-percent rate of deformity considered to be associated with a compromised population (WVDEP, 2010). A 12-percent malformation rate measured in 2008 in adult largemouth bass in the reservoir was thought noteworthy, given that this type of deformity was usually a detriment to survival (WVDEP, 2010). Ovary Se concentrations in bluegill sunfish at the Upper Mud River Reservoir in 2006 varied from 21 to $35 \mu \mathrm{g} / \mathrm{g}$ dry weight, with a mean of $26.2 \mu \mathrm{g} / \mathrm{g}$ dry weight (WVDEP, 2010). Egg Se concentrations measured in three largemouth bass samples from the reservoir site in 2009 were 25,30 , and $65 \mu \mathrm{g} / \mathrm{g}$ dry weight. Both of these setsof Se concentrations exceed egg Se concentrations that caused teratogenic deformities in developing larvae (Lemly, 2002).

Three adult fish with deformities that are likely to be associated with Se toxicity were observed in the mainstem of the Upper Mud River during sampling in May through December 2010 (see photos in Lindberg and others, 2011). Two Lepomis sp. hybrids showing cranial-facial deformities were found at the Upper Mud River below the Laurel Branch. A female creek chub with spinal deformities (lordosis) was found at the Upper Mud River above the Berry Branch in September 2010.

Selenium concentrations in fish samples collected during 2005-2007 within the Upper Mud River basin (WVDEP, 2009,2010 ) exceeded USEPA's proposed a whole-body fishtissue Se criterion of $7.9 \mu \mathrm{g} / \mathrm{g}$ dry weight (USEPA, 2004).

The maximum exceedance of the criterion was approximately 8 -fold for a bluegill sunfish $(60 \mu \mathrm{g} / \mathrm{g})$ in the Upper Mud River Reservoir (WVDEP, 2009).

The Upper Mud River Reservoir currently is under a fishconsumption advisory for mercury, PCBs, and Se to protect human health from the West Virginia Department of Health and Human Resources (WVDHHR, 2012; http://www.wvdhhr.org/ fish/Current_Advisories.asp) and USEPA (2013). The advisory is dependent on both meal size and body weight and, for Se, is based on statewide, not site-specific, guidance. The advisory also notes that Se levels measured in fish would suggest advisories that are consistent with or less restrictive than the statewide consumption advice in place for mercury and PCBs.

\section{Study Area}

\section{Sites and Sampling Design}

Sampling sites are located in southern West Virginia, where the majority of valley fills are found (Shank, 2003, 2004, 2010). Fifteen sampling sites across six basins were chosen in cooperation with the WVDEP. The streams selected for study are listed in table 2, their general locations are shown in figure 4, and specific locational information is given in appendix 1 .

A schematic of the mountaintop coal mining process and valley fill landscape shows a generalized Se pathway and hydrologic settings (stream, reservoir, pond, and outfall) within a basin or watershed (fig. 5). Mining-affected streams and tributaries may contain additional discharge points than depicted, with as many as 105 regulated outlets documented in the Upper Mud River (that is, above Berry Branch) (Lindbergh and others, 2011). In other words, there may be multiple outfalls from a single valley fill. Ten sites were selected for initial study (table 2, noted in bold), with the study later expanded by an additional five sites. Sampling took place during 2010 and 2011. 
The study area lies within the Central Appalachian level III ecoregion, which is further divided into the (1) Cumberland Mountains and (2) Forested Hills and Mountains level IV ecoregions (http://www.epa.gov/wed/pages/ecoregions.htm). The climate in the counties in southern West Virginia where sampling occurred is classified as humid subtropical or mountain temperate (http://koeppen-geiger.vu-vien.ac.at/usa.htm). Records for the city of Charleston (fig. 4) showed an average annual precipitation of 44.05 inches (http://www.erh.noaa.gov/rlx/cliplot/ index. php?tf=annual). For 2010, Charleston received 44.7 inches of precipitation and 62.5 inches of snow. For 2011, precipitation at Charleston was 50.8 inches, with 18.7 inches of snow.

In general, monitoring included analysis of water, suspended particulate material, invertebrate, and wholebody fish-tissue Se concentrations. Fish species collected for Se analysis included creek chub and stoneroller, thus limiting species to ones considered to have a high tolerance to environmental stress based on general comparative fish traits (Stauffer and Ferreri, 2002; Short and others, 2008). In the case of the creek chub, the species also is considered a pioneering species (that is, one that is able to colonize a disrupted ecosystem). A high percentage of highly tolerant species at a stream site is considered a metric of disturbance in scoring the biological integrity of an ecosystem (Karr, 1981). Spring sampling of fish included ovary tissue.

Sampling took place at the initial 10 sites during several seasons of 2010 and 2011 (table 2). White Oak Creek, Seng Creek, Cabin Creek, Beech Creek, and the Birch River were less intensively assessed, with sampling occurring once in 2011 during April and June. Dissolved Se analysis also included dissolved Se speciation. General water-quality also was assessed in several seasons during 2010-2011 through field-measured parameters (temperature, specific conductance, $\mathrm{pH}$, dissolved oxygen, and hardness) and laboratory-measured dissolved constituents (calcium, magnesium, potassium, sodium, iron, manganese, chloride, fluoride, sulfate, and silica)

Stream attribute and physical habitat quality data were collected during the first year of study to determine the range of conditions represented by the initial 10 study sites. Hence, these types of data are not available for White Oak Creek, Seng Creek, Cabin Creek, Beech Creek, and the Birch River. Fish abundance was measured during fall 2010 at the initial 10 study sites. Fish species richness was measured during March 2010 (1 site), fall 2010 (8 sites), and spring 2011 (10 sites).

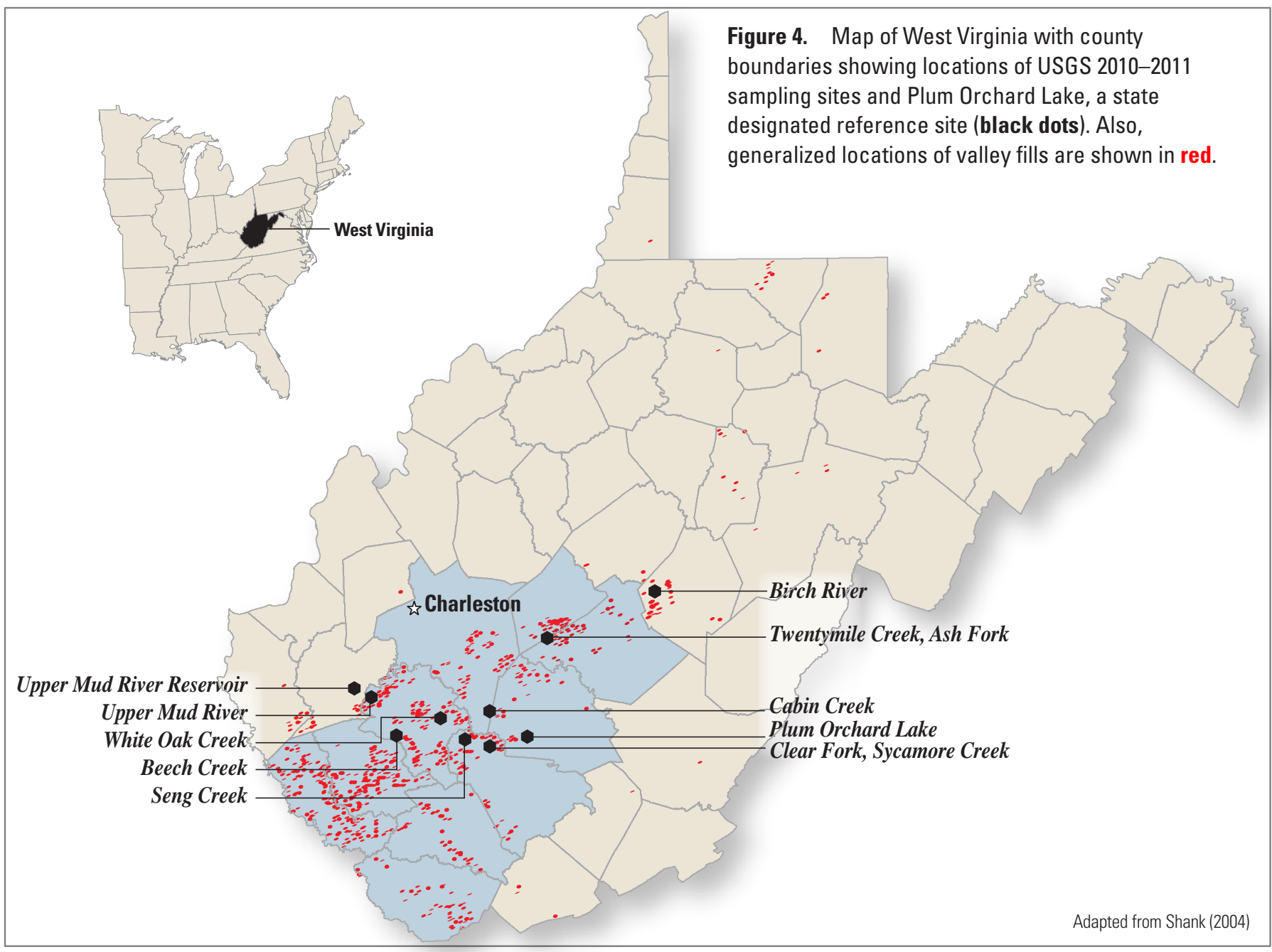




\section{Sampling and Analysis Techniques}

\section{Monitoring Schedule and Collection Methods}

Aqueous samples were collected for Se, Se speciation, and general ion chemistry during three sampling periods (April, August, and November) in 2010 and two sampling periods (February-March and June) in 2011. The U.S. Geological Survey (USGS) National Water-Quality Assessment Program National Field Manual protocols were used, which included depth and width integration across streams (http://pubs. water.usgs.gov/twri9A). In detail, water was filtered using a peristaltic pump equipped with a standard pumphead and highcapacity 0.45 -micrometer $(\mu \mathrm{m})$ filter capsule certified for traceelement background. All tubing was acid-cleaned silicone, and a new length was used at each site and for the blank. At each site, $1 \mathrm{~L}$ of deionized (DI) water was filtered through the filter capsule, followed by site water. The first 200 milliliters of site water eluant were discarded, then $1 \mathrm{~L}$ of eluant was collected in an acid-cleaned 1-L borosilicate glass bottle, acidified, and stored as described earlier for unfiltered water.

Samples were collected by filtration for the separation and analysis of suspended-particulate-material Se concentration during three sampling periods (April, August,
Table 2. Study area watersheds, basins, and sites.

[Sites selected initially for study in bold; other sites added later; gray shading separates different sampled basins]

\begin{tabular}{|c|c|c|c|}
\hline $\begin{array}{l}\text { Hydrologic } \\
\text { region or } \\
\text { watershed }\end{array}$ & Basin & $\begin{array}{l}\text { Field } \\
\text { name }\end{array}$ & Field site \\
\hline \multirow[t]{3}{*}{ Gauley River } & $\begin{array}{l}\text { Twentymile } \\
\text { Creek }\end{array}$ & TCAF & Ash Fork \\
\hline & & TCLO & $\begin{array}{l}\text { Twentymile Creek } \\
\text { lower }\end{array}$ \\
\hline & & TCUP & $\begin{array}{l}\text { Twentymile Creek } \\
\text { upper }\end{array}$ \\
\hline \multirow[t]{5}{*}{ Big Coal River } & Clear Fork & WOCR & White Oak Creek \\
\hline & & SECR & Seng Creek \\
\hline & & CFSC & Sycamore Creek \\
\hline & & CFLO & Clear Fork lower \\
\hline & & CFUP & Clear Fork upper \\
\hline \multirow[t]{4}{*}{$\begin{array}{l}\text { Guyandotte } \\
\text { River }\end{array}$} & $\begin{array}{l}\text { Upper Mud } \\
\text { River }\end{array}$ & MRLF & Left fork Mud River \\
\hline & & MRUB & Upton Branch \\
\hline & & MRLO & Mud River lower \\
\hline & & MRUP & Mud River upper \\
\hline $\begin{array}{l}\text { Upper } \\
\text { Kanawha River }\end{array}$ & Cabin Creek & CACR & Cabin Creek \\
\hline $\begin{array}{l}\text { Little Coal } \\
\text { River }\end{array}$ & Beech Creek & BECR & Beech Creek \\
\hline Elk River & Birch River & BIRI & Birch River \\
\hline
\end{tabular}

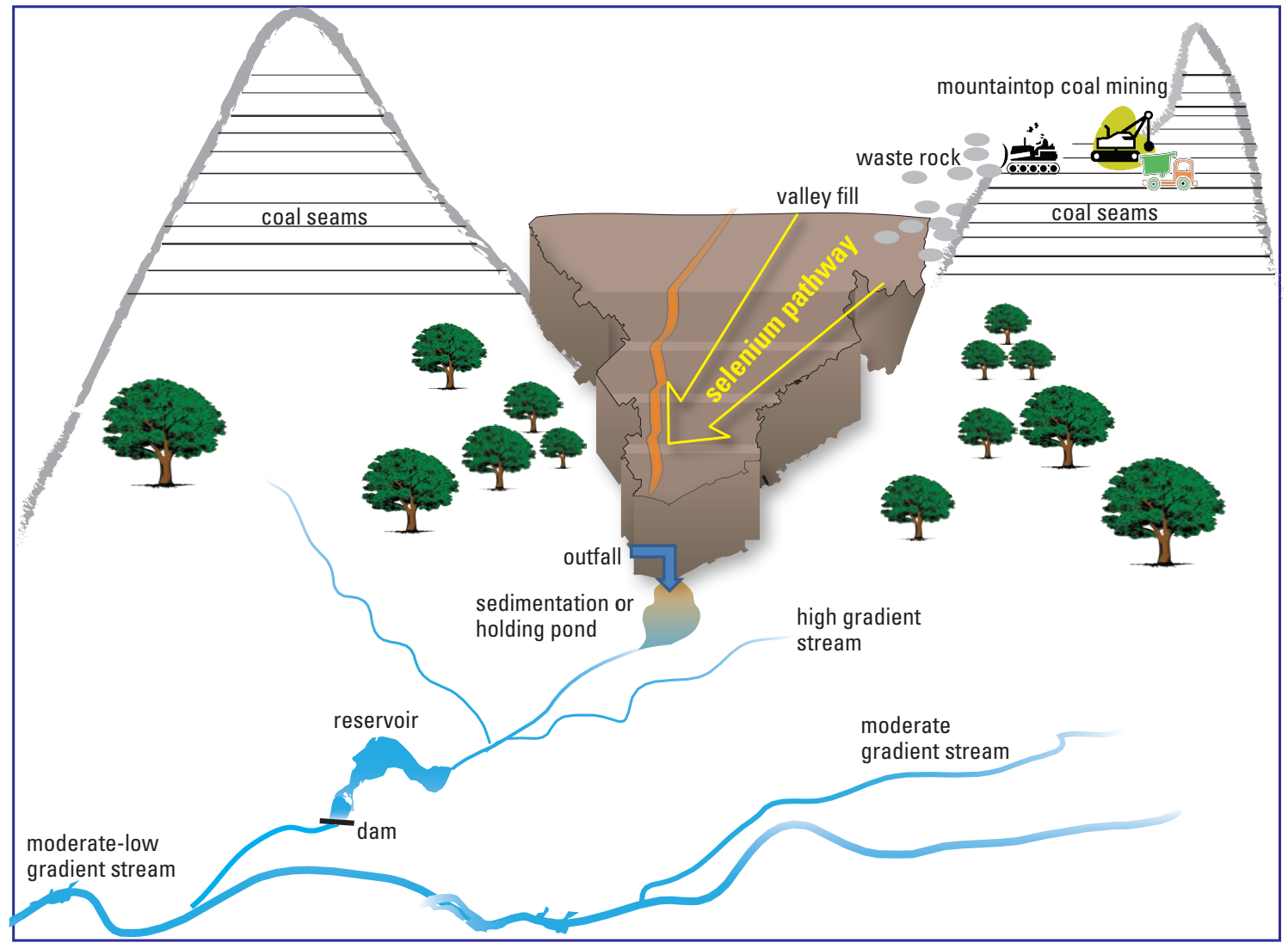

Figure 5. Schematic diagram of the mountaintop coal mining process and valley fill landscape. A Se pathway and hydrologic settings (stream, reservoir, pond, and outfall) are also shown. 
and November) in 2010 and two sampling periods (March and June) in 2011. In detail, a polycarbonate $142-\mathrm{mm}$ plate filter apparatus was used with a $142-\mathrm{mm} 0.4-\mu \mathrm{m}$ pore size polycarbonate filter. At each site, $0.5 \mathrm{~L}$ of DI water was filtered through the plate filter, followed by as much as $1 \mathrm{~L}$ of sample water; after volume notation, the filtrate was discarded. Each filter was placed in a precleaned plastic petri dish $(150$ $\mathrm{mm} \times 15 \mathrm{~mm}$ ) with the particulate side up and sealed with its corresponding cover for freezer storage and transport to the USGS. The plate filtration unit was rinsed with 0.1-percent nitric acid, followed by a DI water rinse after sampling was completed at each site. Selenium data for the 2010 suspendedparticulate-material samples were discarded because of an analysis error. Suspended-particulate-material Se concentrations are reported as dry weight in the solid $(\mu \mathrm{g} / \mathrm{g})$.

Invertebrate samples were collected using a D-frame net (Chambers and Messinger, 2001) during March 2010 and April-May 2011. Samples were frozen on dry ice in the field, then thawed and sorted. In 2010, invertebrates were sorted into a composite aquatic insect sample and (or) a predator aquatic insect sample for each site. In 2011, invertebrates were sorted into either a composite aquatic insect sample or samples consisting of a single aquatic insect taxon (for example, Ephemeroptera, Plecoptera). Samples were refrozen for chemical analysis. Analyses for Se concentrations in invertebrates are reported as dry weight, whole-body.

Backpack electrofishing methods (Murphy and Willis, 1996) were used for collection of creek chub and stoneroller for Se analysis. Fish were collected during three sampling periods: March-April 2010; September-October 2010; and April-May 2011. During the early spring fish sampling (that is, during prespawning), ripe ovaries and whole-body tissue were collected for analysis. During the fall sampling, only wholebody tissue was collected for analysis. Fish weight, standard length (which excludes the length of the caudal fin), and total length were recorded. Fish tissue samples were frozen on dry ice in the field and then shipped for chemical analysis. Wholebody and ovary analyses were determined on separate fish samples. Analyses for Se concentrations in fish are reported as dry weight for whole-body or ovary.

Backpack electrofishing (one pass length at 40 times reach width) also was used to quantify the fish community during March 2010, September-October 2010, and April-May 2011. Fishes were identified in the field, counted, and released (Lazorchak and others, 1998). Fish abundance was measured during fall 2010 at six sites (Twentymile Creek upper and lower; Sycamore Creek; left fork Mud River; and Mud River upper and lower). Fish species richness was measured during spring 2010 at Ash Fork and during fall 2010 at Twentymile Creek upper and lower; Sycamore Creek, Clear Fork upper and lower; left fork Mud River; and Mud River upper and lower. During April-May 2011, richness was measured at Twentymile Creek upper; White Oak Creek; Seng Creek; Sycamore Creek; Clear Fork upper; left fork Mud River; Mud River upper; Cabin Creek; Beech Creek; and the Birch River.
Physical habitat data collected during July 2010 included measurement of conductivity, water temperature, percent riparian forest cover, wetted width, thalweg depth, flow velocity, mesohabitat components (cascade, pool, riffle, run), and substrate composition (clay, sand, gravel, cobble, boulder, bedrock) at the initial 10 sites. Sampling protocols implemented were those developed by the USGS and the USEPA (Lazorchak and others, 1998; Paybins and others, 2000; Chambers and Messinger, 2001). Substrate size was quantified by classifying 100 randomly selected particles among size categories (Wentworth scale) as described by Wolman (1954). Stream depths and mesohabitat conditions were measured in 100 evenly spaced locations that followed the thalweg from the downstream to upstream limits of the reach. In each of the 100 sampling points, thalweg depth was measured with a wading rod and mesohabitat type was classified as riffle, pool, or run. Canopy cover was measured with a spherical densiometer at cardinal directions for 11 evenly spaced transects along a sample reach (44 observations per site). Stream parameter data were augmented by a compilation of estimated median discharges for all 15 sites (written commun., J. Wirts, WVDEP, 2013).

\section{Laboratory Methods}

Samples for Se were analyzed by flow injection hydride generation atomic absorption spectrophotometry (FIHGAAS) at the USGS Columbia Environmental Research Center (CERC) in Columbia, Missouri.

\section{Chemical Procedures}

Total Dissolved Se in Water.-Before analysis, all water samples were stored in the dark at $\sim 4{ }^{\circ} \mathrm{C}$. For the subsequent determination of total dissolved Se in filtered samples, a 20-mL aliquot of each acidified water sample was subjected to an $\mathrm{HNO}_{3}$-magnesium nitrate $\left[\mathrm{Mg}\left(\mathrm{NO}_{3}\right)_{2}\right]$ ashing procedure, followed by treatment with $\mathrm{HCl}$. The ashing procedure consisted of three steps: boiling with $\mathrm{HNO}_{3}$ for solubilization and partial oxidation; ashing at $500{ }^{\circ} \mathrm{C}$ with $\mathrm{Mg}\left(\mathrm{NO}_{3}\right)_{2}$ to complete the oxidation and decompose remaining organic matter; and heating with $20 \mathrm{~mL}$ of 50-percent (by volume) $\mathrm{HCl}$ to dissolve the ash and chemically reduce $\mathrm{Se}$ to the selenite $\left(\mathrm{Se}^{+4}\right)$ oxidation state required for detection by hydride generation atomic absorption spectrophotometry. Following reduction, digestates were diluted to $\sim 100 \mathrm{~mL}$ with deionized (DI) water, yielding a final acid matrix of 10 percent $\mathrm{HCl}$.

Selenite + Selenate in Water.-Ten $\mathrm{mL}$ of filtered water and $5 \mathrm{~mL}$ of concentrated $\mathrm{HCl}$ were placed in a $25-\mathrm{mL}$ borosilicate test tube and heated to about $130^{\circ} \mathrm{C}$ in a well incubator block for 3 to 4 hours. After cooling, the liquid was transferred into a $125-\mathrm{mL}$ polyethylene bottle, and the final volume was adjusted to $50 \mathrm{~mL}$ with DI water. The final matrix was 10 percent $\mathrm{HCl}$. 
Filtered Particulate Se.-A dried filter containing particulates was rolled up, cut into pieces, and the entire filter was put into a $100-\mathrm{mL}$ glass beaker. The filter was then subjected to the ashing procedure as described earlier for total dissolved Se in water. The same procedure was conducted on clean filters, which served as blanks.

Biological Sample Se.-Preparation and analysis of all biota tissue samples was conducted by CERC. Small fish samples were chopped and minced with a meat cleaver, but larger samples were processed through a Hobart band saw and meat grinder. Invertebrate and fish ovary samples needed no initial homogenization. All samples were lyophilized (freeze-dried), and percent moisture was determined in conjunction with the lyophilization procedure. Following lyophilization, small fish, invertebrate, and fish ovary samples were mechanically ground with a glass rod to a coarse powder. For larger fish samples, the dried cake product was hand-kneaded in a plastic bag to a coarse uniform powder. Each ground sample product was stored in a $40-\mathrm{mL}$ glass vial in a dessicator prior to further treatment. Dried fish, fish ovary, or invertebrate samples (approximately 0.2 to $0.5 \mathrm{~g}$ ) were subjected to a nitric acid-magnesium nitrate dry ashing procedure (Brumbaugh and Walther 1989).

\section{Instrumental Analysis}

Total Se.-Total Se was determined in all ashed samples (filtered water, filtered suspended particulates, and tissue) by flow injection hydride generation atomic absorption spectrophotometry (FIHGAAS). In this procedure, the digestate is mixed with an $\mathrm{HCl}$ carrier solution and then reduced by sodium tetrahydridoborate that has been stabilized with sodium hydroxide. Selenium in the sample is converted to volatile hydrogen selenide and transferred with argon carrier gas into a heated quartz cell mounted on an atomic absorption spectrophotometer for decomposition into atomic vapor and measurement.

Selenite in Water.-An aliquot of each filtered water sample was analyzed directly by FIHGAAS after acidification to 10 percent $\mathrm{HCl}$.

Selenate and Selenite in Water.-Filtered water samples were subjected to heating for 1 hour with 50 percent $\mathrm{HCl}$ to chemically reduce the selenate species to selenite. Samples prepared in this manner were analyzed directly by FIHGAAS to provide selenate + selenite concentrations. The selenate concentration was calculated by difference using the formula:

$$
\text { selenate }=(\text { selenate }+ \text { selenite })-\text { selenite }
$$

Particulate Se in Water.-Selenium associated with filtered particulates was determined by analyzing ashed filters by FIHGAAS.

Dissolved Organic Se in Water.-Dissolved organic Se was estimated using the following formula:

$$
\begin{gathered}
\text { dissolved organic } \mathrm{Se}=\text { total dissolved } \\
\mathrm{Se}-(\text { selenate }+ \text { selenite })
\end{gathered}
$$

Total dissolved Se is defined as the analysis of filtered water for total Se. All reported Se concentrations in solids are reported in dry weight.

Selenium Detection Limits. - Instrumental detection limits for Se over the course of the study were $0.028,0.033$, and $0.040 \mu \mathrm{g} / \mathrm{L}$. Method detection limits (MDLs) were calculated for each matrix for Se and were computed for each analytical block of samples using the formula: $3\left(\mathrm{SD}_{\mathrm{b}}{ }^{2}\right.$ $\left.+\mathrm{SD}_{\mathrm{s}}^{2}\right)^{1 / 2}$, where $\mathrm{SD}_{\mathrm{b}}=$ standard deviation of a blank $(\mathrm{n}=3)$ and $\mathrm{SD}_{\mathrm{s}}=$ standard deviation of a low-level sample or spiked sample $(n=3)$. For total dissolved Se and Se species in water, the range of MDLs $(\mu \mathrm{g} / \mathrm{L})$ was $0.030-0.59$. For total Se in filtered particulates, the range of MDLs was $0.002-0.36$ $\mu \mathrm{g} / \mathrm{L}$. For biota, the range of MDLs ( $\mu \mathrm{g} / \mathrm{g}$ dry weight) was $0.015-0.047$.

Dissolved Ion Chemistry in Water.--Samples for dissolved ion chemistry were analyzed at the USGS National Water Quality Laboratory, Denver, Colorado, using the methods described at http://water.usgs.gov/owq/methods.html and http://wwwnwql.cr.usgs.gov/USGS.shtml.

\section{Modeling Approach: Ecosystem-Scale Selenium Modeling}

\section{Overview}

Assessing the biotransfer of Se through ecosystems is essential for quantifying the linkages between $\mathrm{Se}$ concentrations in environmental media and toxicity. Sitespecific modeling of ecosystems in southern West Virginia is based upon Se concepts and parameters developed for a wide variety of aquatic systems and their food webs (Luoma and Rainbow, 2005; Luoma and Presser, 2009; Presser and Luoma, 2006, 2010a,b). A schematic of the methodology for ecosystem-scale modeling is given in figure 6 , along with the biogeochemical and physiological factors and equations needed to run the model. Quantifying the relations depicted in the model requires environmental partitioning factors $\left(\mathrm{K}_{\mathrm{d}} \mathrm{s}\right)$ to address transformation of dissolved Se into particulate forms and biodynamic trophic transfer factors (TTFs) to address uptake and efflux by consumer species and their predators. The final set of equations in figure 6 illustrates how the model can be used for translating an assumed predator-tissue Se guideline to a dissolved Se concentration.

Validation of the broader ecosystem-scale Se modeling approach was accomplished by comparing model forecasts with field data across a range of common food webs and hydrologic environments (Luoma and Rainbow, 2005; 
Presser and Luoma, 2006, 2009, 2010a,b, 2013). Selenium concentrations in predators can be predicted with strong correlation to observations from nature if particulate $\mathrm{Se}$ concentrations are known and an appropriate food web is used for the predator (Luoma and Presser, 2009; Presser and Luoma, 2010a).

The biodynamically based methodology builds from five basic principles that determine ecological risks from Se in sitespecific aquatic environments: (1) dissolved Se transformation to particulate material Se sets dynamics at the base of the food web; (2) diet drives bioavailability of Se to animals); (3) Se bioaccumulation differs widely among invertebrates, but not necessarily among fish; (4) ecological risk from Se differs among food webs and predator species; and (5) Se risk for each predator is driven by a combination of the biodynamics of Se exposures via their specific food web and the species' inherent sensitivity to Se toxicity. Here, the ecosystem-scale methodology and conceptualization is adapted to the sitespecific hydrologic settings and food webs of the aquatic ecosystems of southern West Virginia. Additional layers of specificity in modeling can address such temporal exposure factors as Se source dynamics, discharge regime (that is, water residence time or gradient), food availability, and life stages of predators and their habitat use.

In the final modeling step, effects on the reproduction of predaceous fish (for example, incidence of larval deformity) are determined by comparison of model outputs of bioaccumulated Se concentrations in predators and known Se toxicity guidelines (for example, USEPA, 2004; Skorupa and others, 2004; Presser and Luoma, 2006; Janz and others, 2010). Selenium is one of the few trace elements for which tissue concentrations have been correlated to these adverse effects in both toxicity tests and field studies (Luoma and Rainbow, 2008). Toxicity data for site-specific fish species (for example, creek chub, stoneroller) are limited. The necessity of establishing effects thresholds from surrogate species adds some uncertainty to a final assessment of risk. Therefore, different possible choices for such thresholds are used in model exposure scenarios to illustrate the implication of different management and regulatory proposals or actions to quantify Se toxicity.

The intent here is to validate the model and illustrate the model's capability under varying site-specific hydrologic and food-web conditions, mainly those conditions useful to management decisions. An application of the model that derives a dissolved Se concentration from a chosen Se toxicity guideline is suitable for developing a range of limits and establishing an understanding of relevant and controlling variables. However, the overall outcomes and implications for selection of a specific dissolved Se concentration as a protective guideline will be those generated by modeling choices and guidance given by state and other agencies in their decisionmaking processes. Finally, additional refinements to the ecosystem-scale site-specific approach are listed in an effort to narrow uncertainty and help expand the usefulness and expediency of the model.

\section{Model Components}

\section{Partitioning/Transformation from Dissolved to Particulate Phase: Selenium Concentrations in Particulates at the Base of the Food Web}

Phase transformation reactions from dissolved to particulate Se (Cutter and Bruland, 1984; Besser and others, 1989; Oremland and others, 1989; Doblin and other, 2006) are of toxicological significance because particulate Se is the primary form by which Se enters food webs (Luoma and Fisher, 1997; Luoma and others, 1992; Luoma and Rainbow, 2005; Presser and Luoma, 2010). The different biogeochemical transformation reactions also result in different forms of Se in particulate material: organo-Se, elemental Se, or adsorbed Se. The resulting particulate Se speciation, in turn, affects the bioavailability of Se to invertebrates, depending upon how an invertebrate "samples" the complex water/sediment/particulate milieu that composes its environment.

Dissolved Se can exist as selenate, selenite, or organoselenide $\left(+6, \mathrm{SeO}_{4}^{-2} ;+4, \mathrm{SeO}_{3}^{-2} ;-2\right.$, Se-II or organo-Se, respectively). The dissolved species of Se that are present will influence the type of phase transformation reaction that creates particulate Se. Examples of types of reactions include (1) uptake by plants and phytoplankton of selenate, selenite, or dissolved organo-Se and reduction to particulate organo-Se by assimilatory reduction (see, for example, Sandholm and others, 1973; Riedel and others, 1996; Wang and Dei, 1999; Fournier and others, 2006); (2) sequestration of selenate into sediments as particulate elemental Se by dissimilatory biogeochemical reduction (for example, Oremland and others, 1989); (3) adsorption as coprecipitated selenate or selenite through reactions with particle surfaces; and (4) recycling of particulate phases back into water as detritus after organisms die and decay (see, for example, Velinsky and Cutter, 1991; Reinfelder and Fisher, 1991; Zhang and Moore, 1996).

\section{Residence Time}

The conditions in the receiving-water environment also are important to phase transformation. Where selenate is the only form of Se and residence times are short (for example, fast-flowing rivers), the limited reactivity of selenate means partitioning of Se into particulate material tends to be low. Similarly, dissimilatory reduction does not seem efficient unless water residence times are extended. Longer water residence times, in sloughs, lakes, wetlands, and estuaries for example, seem to allow greater uptake by plants, algae, and microorganisms. This is accompanied by greater recycling of selenite and organo-Se back into solution, further accelerating uptake (Bowie and others, 1996; Lemly, 2002; Meseck and Cutter, 2006). Neither selenite nor organo-Se is easily reoxidized to selenate because the reaction takes hundreds of years (Cutter and Bruland, 1984). So the net outcome in a watershed that flows through wetland areas or estuaries is 
a gradual build-up of selenite and organo-Se in water and higher partitioning into particulate material (Lemly, 1999; Presser and Luoma, 2009, 2013). Environments downstream in a watershed also can have higher concentrations of selenite and organo-Se, which reflects the cumulative contributions of upstream recycling in a hydrologic system.

Differences in Se bioaccumulation have been described between lotic (stream) and lentic (lake) environments (Hamilton and Palace, 2001; Brix and others, 2005; Orr and others, 2006). This could at least partly reflect the observations above: if other conditions are similar, environments with longer residence times, like lakes, tend to have greater recycling, a higher ratio of particulate/dissolved Se, and higher concentrations of Se entering the food web. Exceptions also occur, however. For example, discharge period or season might be a consideration even within individual segments of a watershed, with watershed dilution potentially balancing a longer downstream residence time at a particular site.

\section{Particle Type and Data Requirements}

The base of the food web, as sampled in the environment, can include phytoplankton, periphyton, detritus, inorganic suspended material, biofilm, sediment, or attached vascular plants. For simplicity, in discussions here, particulate material is defined as this mixture of living and nonliving entities (Luoma and others, 1992). At a minimum, interpretation and modeling of particulate Se concentration data should take into consideration the nature of the particulate material and the feeding requirements of the invertebrate food web that is modeled.

Field data for Luscar Creek in Alberta, Canada, show a hierarchy of Se concentrations in particulate phases: $2.4 \mu \mathrm{g} / \mathrm{g}$ in sediment; $3.2 \mu \mathrm{g} / \mathrm{g}$ in biofilm; and $5.5 \mu \mathrm{g} / \mathrm{g}$ for filamentous algae (Casey, 2005). In that regard, collection of one consistent type of material that can be compared among locations is a study option. If data are available, averaging concentrations of Se in sediment, detritus, biofilm, and algae to define a particulate phase may help to take into account partitioning in different media and best represent the dynamic conditions present in an aquatic system. Linkage to a specified invertebrate taxon also can set particulate choices and lead to further refinement of model inputs. Bed sediment is the least desirable choice for representing the base of the food web, especially if the sediments vary from sand to fine-grained among the samples. In general, sandy sediments dilute concentrations with a high mass of inorganic material that diminishes connections to food webs (Luoma and Rainbow, 2008).

A metric describing partitioning of Se between particulate material and dissolved phases (that is, $\mathrm{K}_{\mathrm{d}}$ ) is discussed later. This metric allows determination of a dissolved $\mathrm{Se}$ concentration that would be responsible for a site-specific Se fish body burden (that is, a link between dissolved Se concentration and toxicity). Hence, regulatory application is possible to give the implications of management decisions and tie dissolved Se concentration to Se toxicity as long as intervening steps are adhered to and sufficient data are available (see "Model Application" section).

\section{Uptake into Food Webs and TTFs: Selenium Concentrations in Prey and Predators}

Kinetic bioaccumulation models (that is, biodynamic models) account for the now well established principle that Se bioaccumulates in food webs principally through dietary exposure (Luoma and Fisher, 1997; Luoma and Rainbow, 2005, 2008). Tissue Se attributable to dissolved exposure makes up less than 5 percent of overall tissue Se in almost all circumstances (Fowler and Benayoun, 1976; Luoma and others, 1992; Roditi and Fisher, 1999; Wang and Fisher, 1999; Wang, 2002; Schlekat and others, 2004; Lee and others, 2006). Biodynamic modeling (fig. 6) shows that Se bioaccumulation (the concentration achieved within the organism) is driven by physiological processes specific to each species (Reinfelder and others, 1998; Wang 2002; Baines and others, 2002; Stewart and others, 2004). Biodynamic models have the further advantage of providing a basis for deriving a simplified measure of the linkage between trophic levels-TTFs. For each species, a TTF can be derived from either experimental studies or field observations, where the TTF defines the relationship between Se concentrations in an animal and in its food (dry weight).

Experimental derivation of TTFs is based on the capability of a species to accumulate Se from dietary exposure as expressed in the biodynamic equation (Luoma and Rainbow, 2005):

$$
\mathrm{d} C_{\text {species }} / \mathrm{d} t=(\mathrm{AE})(\mathrm{IR})\left(C_{\text {food }}\right)-\left(k_{\mathrm{e}}+k_{g}\right)\left(C_{\text {species }}\right)
$$

where $C_{\text {species }}$ is the contaminant concentration in the animals ( $\mu \mathrm{g} / \mathrm{g}$ dry weight), $t$ is the time of exposure in days (d), AE is the assimilation efficiency from ingested particles (percent), IR is the ingestion rate of particles ( $\mathrm{g} / \mathrm{g} /$ day), $C_{\text {food }}$ is the contaminant concentration in ingested particles ( $\mu \mathrm{g} / \mathrm{g}$ dry weight), $k_{\mathrm{e}}$ is the efflux rate constant (per day) that describes Se excretion or loss from the animal, and $k_{\mathrm{g}}$ is the growth rate constant (per day). The equation shows that key determinants of Se bioaccumulation are the ingestion rate of the animal, the efficiency with which Se is assimilated from food, and the rate constant describing Se turnover or loss from the tissues of the animal (Luoma and Rainbow, 2005; Presser and Luoma, 2010a). Experimental protocols for measuring such parameters as AE, IR, $k_{\mathrm{e}}$ are now well developed for aquatic animals (Wang and others, 1996; Luoma and Rainbow, 2005).

In the absence of rapid growth, a simplified, resolved biodynamic exposure equation for calculating a $\mathrm{Se}$ concentration in an invertebrate (fig. 6) is:

$$
C_{\text {invertebrate }}=\left[(\mathrm{AE})(\mathrm{IR})\left(C_{\text {particulate }}\right)\right] \div\left[k_{\mathrm{e}}\right]
$$

For modeling, these physiological parameters can be combined to calculate a $\mathrm{TTF}_{\text {invertebrate }}$, which characterizes the potential for each invertebrate species to bioaccumulate Se. $\mathrm{TTF}_{\text {invertebrate }}$ is defined as

$$
\mathrm{TTF}_{\text {invertebrate }}=[(\mathrm{AE})(\mathrm{IR})] \div k_{\mathrm{e}}
$$


Figure 6. Diagram of the components and equations for ecosystem-scale Se modeling that emphasizes food-web biodynamics. Quantifying factors include: $\mathrm{K}_{\mathrm{d}}=$ empirically determined environmental partitioning factor between water and particulate material; and TTF = biodynamic food-web transfer factor between an animal and its food. Adapted from Presser and Luoma (2010a).
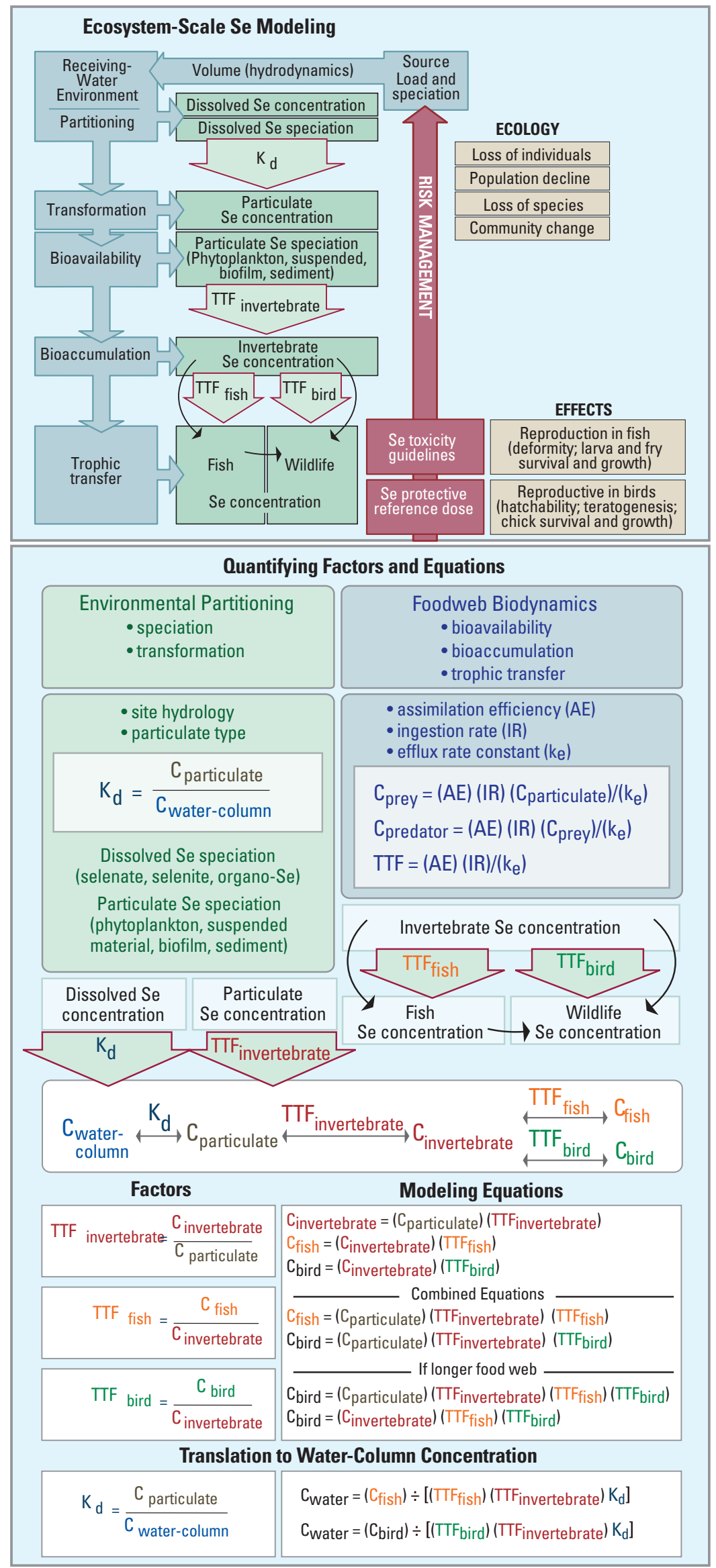

Adapted from Presser and Luoma (2010)

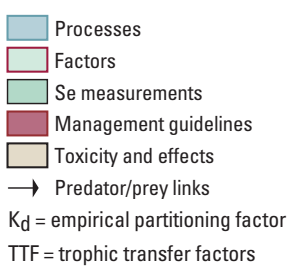

TTF = trophic transfer factors 
Similarly, food-web biodynamic equations for fish or birds are

$$
\begin{aligned}
& C_{\text {fish or bird }}=\left[(\mathrm{AE})(\mathrm{IR})\left(C_{\text {invertebrate }}\right)\right] \div k_{\mathrm{e}} ; \\
& \text { and } \mathrm{TTF}_{\text {fish or bird }}=\left[(\mathrm{AE}(\mathrm{IR})] \div k_{\mathrm{e}}\right.
\end{aligned}
$$

Where laboratory data are not available, a field $\mathrm{TTF}_{\text {invertebrate }}$ can be defined from spatially and temporally matched datasets (in dry weight or converted to dry weight) of particulate and invertebrate Se concentrations (fig. 6) as

$$
\mathrm{TTF}_{\text {invertebrate }}=C_{\text {invertebrate }} \div C_{\text {particulate }}
$$

A field derived species-specific $\mathrm{TTF}_{\text {fish }}$ is defined as

$$
\mathrm{TTF}_{\text {fish }}=C_{\text {fish }} \div C_{\text {invertebrate }}
$$

where $C_{\text {invertebrate }}$ is for a known prey species, $C_{\text {fish }}$ is reported as muscle or whole-body tissue, and both Se concentrations are reported in $\mu \mathrm{g} / \mathrm{g}$ dry weight (fig. 6). If necessary, the modeling approach can represent a diet that includes a mixed proportion of prey in the diet through use of the equation

$$
\begin{aligned}
C_{\text {fish }}= & \left(\mathrm{TTF}_{\text {fish }}\right)\left[\left(C_{\text {invertebrate a }}\right) \text { (prey fraction }\right)+\left(C_{\text {invertebrate } \mathrm{b}}\right) \\
& \left.(\text { prey fraction })+\left(C_{\text {invertebrate }}\right)(\text { prey fraction })\right]
\end{aligned}
$$

Equations are combined to represent step-wise bioaccumulation from particulate material through invertebrate to fish (fig. 6) as

$$
C_{\text {fish }}=\left(\mathrm{TTF}_{\text {invertebrate }}\right)\left(C_{\text {particulate }}\right)\left(\mathrm{TTF}_{\text {fish }}\right)
$$

Similarly for birds, the combined equation is

$$
C_{\text {bird }}=\left(\mathrm{TTF}_{\text {invertebrate }}\right)\left(C_{\text {particulate }}\right)\left(\mathrm{TTF}_{\text {bird }}\right)
$$

Modeling can accommodate longer food webs that contain more than one higher trophic level consumer (for example, forage fish being eaten by predatory fish) by incorporating additional TTFs. One equation for this type of example (fig. 6) is

$$
\begin{gathered}
C_{\text {predator fish }}=\left(\mathrm{TTF}_{\text {invertebrate }}\right)\left(C_{\text {particulate }}\right) \\
\left(\mathrm{TTF}_{\text {forage fish }}\right)\left(\mathrm{TTF}_{\text {predator fish }}\right)
\end{gathered}
$$

Modeling for bird tissue also can represent Se transfer through longer or more complex food webs (for example, TTFs for invertebrate to fish and fish to birds) as

$$
C_{\text {bird }}=\left(\mathrm{TTF}_{\text {invertebrate }}\right)\left(C_{\text {particulate }}\right)\left(\mathrm{TTF}_{\text {fish }}\right)\left(\mathrm{TTF}_{\text {bird }}\right)
$$

Variability or uncertainty in processes that determine AEs or IRs can be directly accounted for in sensitivity analysis (Wang and others, 1996). That is accomplished by considering the range in experimental observations for the specific animal in the model. Field-derived factors require some knowledge of feeding habits and depend on available data for that species. Laboratory and field factors for a species can be compared and refined to improve levels of certainty in modeling.

A substantial number of species-specific TTFs are available for modeling, allowing linkages of particulate Se concentrations to invertebrate and predator Se concentrations (Luoma and Presser, 2009; Presser and Luoma, 2010a). Their derivation is extensively discussed in Presser and Luoma (2010a). These are enough data at least to begin to model important food webs. For invertebrates, the range of $\mathrm{TTF}_{\text {invertebrate }}$ for freshwater and marine species or taxa is $0.6-23$. Of the 29 species or taxa listed in Presser and Luoma (2010b), 27 species have TTFs $>1$. Thus, most invertebrates bioaccumulate as much as or more Se than the trophic level below them, with the concentration of Se biogeochemically transformed into algae, microbes, seston, or sediments preserved and (or) (bio) magnified as Se passes up food webs.

Relevant here, freshwater invertebrate TTFs compiled for modeling range from 0.9 for amphipods to 6.0 for zebra mussels (Presser and Luoma, 2010a). Invertebrate TTFs fall into several broad categories in terms of bioaccumulative potential and include means of 1.0 for amphipods; 1.3 to 1.9 for crustaceans; 2.8 for aquatic insects; and 2.8 to 6.0 for clams and mussels. To illustrate the level of uncertainty for one group of organisms, the value for $\mathrm{TTF}_{\text {aquatic insect }}$ used in modeling (2.8) can be compared with several sets of data for insects that include mayfly, caddisfly, cranefly, stonefly, damselfly, corixid, and chironomid (TTF range 2.3-3.2) (Presser and Luoma, 2010a). The $\operatorname{TTF}_{\text {damselfy }}(2.6)$ for a predatory insect did not differ from TTFs for aquatic insects that spend the majority of their life span in the larvae stage; however, limited data were available to calculate a field-derived $\mathrm{TTF}_{\text {damselfly }}$ (Presser and Luoma, 2010a). Thus, in modeling, aquatic insects were considered generally as prey, but site-specific conceptual models could accommodate predatory insects as a higher trophic level component.

Trophic transfer factors for both freshwater and marine fish species from the available literature, on the other hand, have a median of approximately 1 and a range of 0.5-1.8 (Presser and Luoma, 2010a). Compilations of TTFs for different fish species derived from laboratory and field studies have similar ranges: $0.5-1.8$ and $0.6-1.7$, respectively.

\section{Assessment Results and Analysis}

\section{Regional Selenium Environment}

Recent regional Se concentrations were compiled to assess a range of diverse settings and their potential for Se bioaccumulation (figs. 7-10). Food-web species and dissolved, particulate, and tissue Se concentrations are the types of data that are the basis for development of conceptual food-web models for a site and are essential components for understanding the biotransfer of Se within ecosystems (that is, ecosystem-scale Se modeling). All suspended- particulate-material and tissue Se concentrations given in the assessment and used in modeling are in dry weight (dw). Whole-body (wb) and ovary fish tissues were assessed, but wb fish tissue was used in modeling. 
Examples of dietary ( 4.5 and $7.2 \mu \mathrm{g} / \mathrm{g} \mathrm{dw})$ and fishtissue (5.0 and $7.9 \mu \mathrm{g} / \mathrm{g}$ wb dw) Se toxicity guidelines are noted for reference (USEPA, 1987, 2004; Skorupa and others, 2004; Presser and Luoma, 2006; 2010a,b; 2013)

(figs. 8-10). These illustrated guidelines are within the range of guidelines being discussed in the literature, but their use is not intended as an endorsement of the values. Rather, the guidelines are included to bring context to the range of Se concentrations found regionally and during the 2010-2011 study reported here for southern West Virginia ecosystems affected by mountaintop mining and valley fills.

\section{Water Column}

The Upper Mud River basin in the Lower Guyandotte River watershed was the focus of recent studies because of the presence of the Hobet Mining Complex. Water-column monitoring (nonfiltered water samples) of the Mud River between river miles 74 and 77 from November 2005 to June 2009 showed the variability in Se concentrations across seasons (fig. 7A) (WVDEP, 2010). Within this noncontinuous sampling, the river reached a water-column maximum of $22 \mu \mathrm{g} / \mathrm{L}$ in June 2007 and a minimum of $4.0 \mu \mathrm{g} / \mathrm{L}$ in March 2006. Monitoring in 2009-2010 at an upstream site (upstream of Ballard Branch) and a downstream site (downstream of Berry Branch) showed, in general, increased water-column Se concentrations downstream (fig. 7B) (Potesta and Associates, Inc, 2011a). In July 2009, the river reached an upstream water-column maximum Se concentration of $11.2 \mu \mathrm{g} / \mathrm{L}$ and a downstream maximum of $18.0 \mu \mathrm{g} / \mathrm{L}$. For comparison, dissolved Se concentrations for the Upper Mud Reservoir were $3.7 \mu \mathrm{g} / \mathrm{L}$ at the right fork and $0.15 \mu \mathrm{g} / \mathrm{L}$ at the left fork in June 2008 (U.S. Geological Survey, 2008) (fig. 8A). In addition, the Se concentration in tail-water exiting the dam of the reservoir measured $3.2 \mu \mathrm{g} / \mathrm{L}$ during earlier studies in 2006-2007 (WVDEP, 2009).

\section{Suspended Particulate Material}

Few suspended-particulate-material Se concentrations are available for southern West Virginia basins. Data collected in 2008 from studies of the right fork of the Upper Mud River Reservoir and the Upper Mud River itself illustrated the difference in Se concentrations of bed sediment and suspended-particulatematerial samples (fig. 8B). Comparative samples from two sites showed higher Se concentrations in suspended particulate material $(1.7$ and $6.7 \mu \mathrm{g} / \mathrm{g} \mathrm{dw})$ than in bed sediment ( 0.9 and $2.8 \mu \mathrm{g} / \mathrm{g} \mathrm{dw}$, respectively). As noted previously, the characterization of the type or phase of particulate material and analysis of its Se concentration are important in quantifying Se exposure of prey through the base of the food web and key to successful ecosystemscale Se modeling (Presser and Luoma, 2010a).

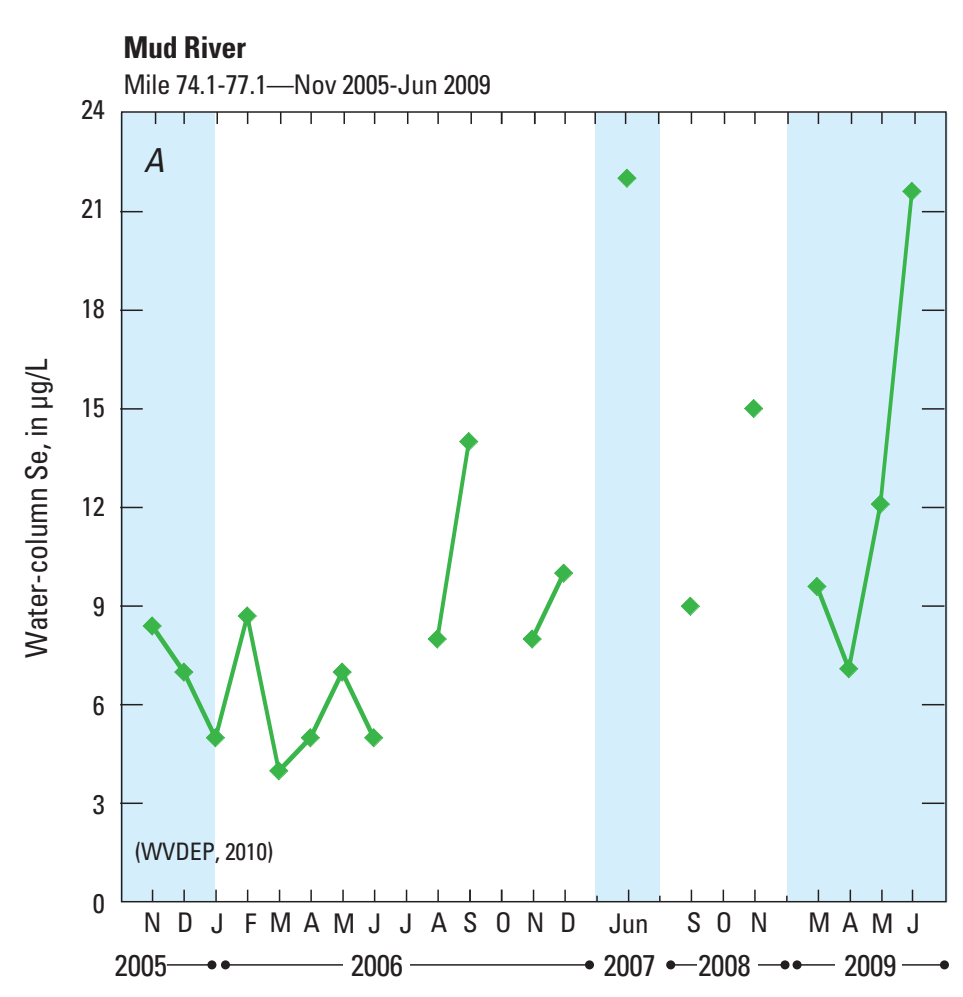

Mud River

Upstream of Ballard Branch and downstream of Berry Branch—Jun 2009-Jul 2010

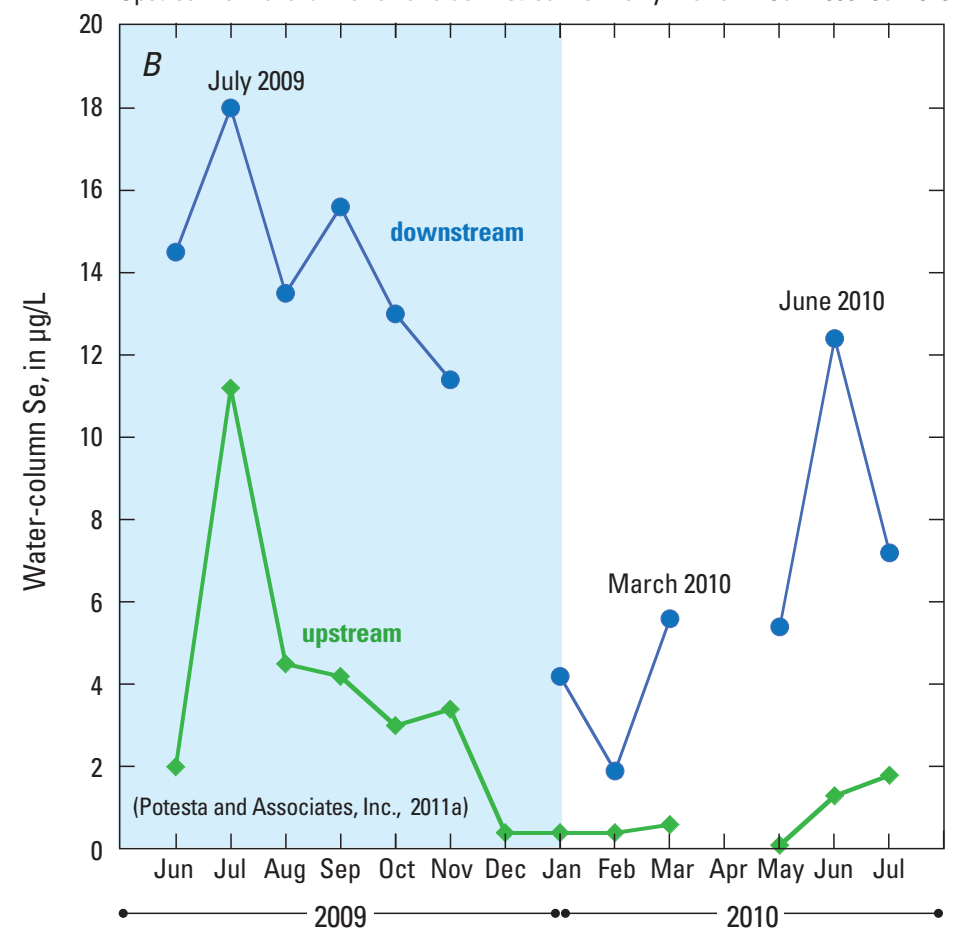

Figure 7. Graph showing water-column Se concentrations at different times for the Mud River $(A)$ at miles 74.1-77.1; and $(B)$ upstream of Ballard Branch and downstream of Berry Branch. 
Upper Mud River Reservoir and Plum Orchard Lake

A. Water-column (USGS, 2008; WVDEP, 2009)

\begin{tabular}{|c|c|}
\hline June & $\begin{array}{l}\text { Upper Mud River Reservoir } \\
\text { Right fork } \\
\text { dissolved Se }=3.7 \mu \mathrm{g} / \mathrm{L} \\
\text { speciation }=96 \% \text { selenate and } 4 \% \text { selenite }\end{array}$ \\
\hline 2008 & $\begin{array}{l}\text { Left fork } \\
\text { dissolved } \mathrm{Se}=0.15 \mu \mathrm{g} / \mathrm{L}\end{array}$ \\
\hline $\begin{array}{l}\text { April } 2006- \\
\text { May } 2007\end{array}$ & $\begin{array}{l}\text { Tailwater from dam } \\
\text { water-column } \mathrm{Se}=3.2 \mu \mathrm{g} / \mathrm{L} \\
\text { speciation }=91 \% \text { selenate; } 9 \% \text { selenite }\end{array}$ \\
\hline $\begin{array}{l}\text { April 2006- } \\
\text { May } 2007\end{array}$ & $\begin{array}{l}\text { Plum Orchard Lake (minimal mining impact) } \\
\text { water-column } \mathrm{Se}=<1 \mu \mathrm{g} / \mathrm{L}\end{array}$ \\
\hline
\end{tabular}
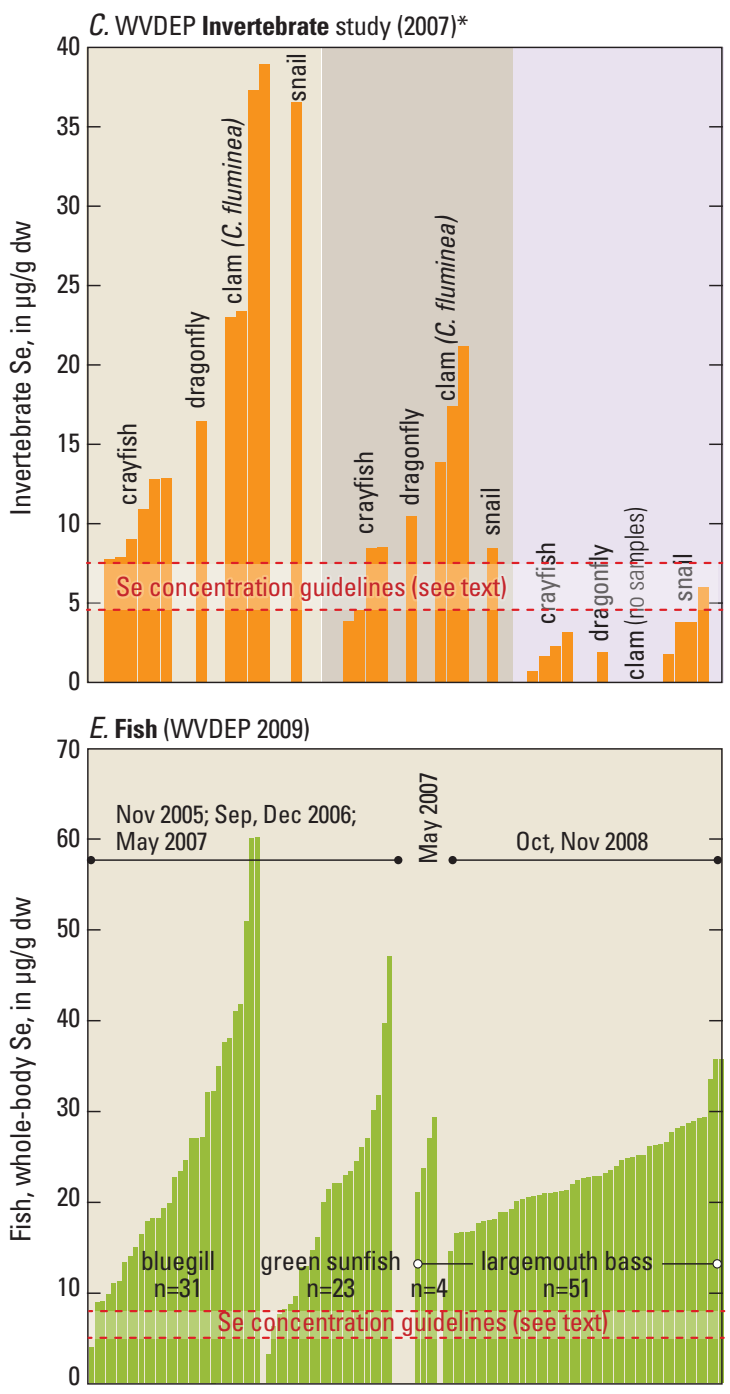
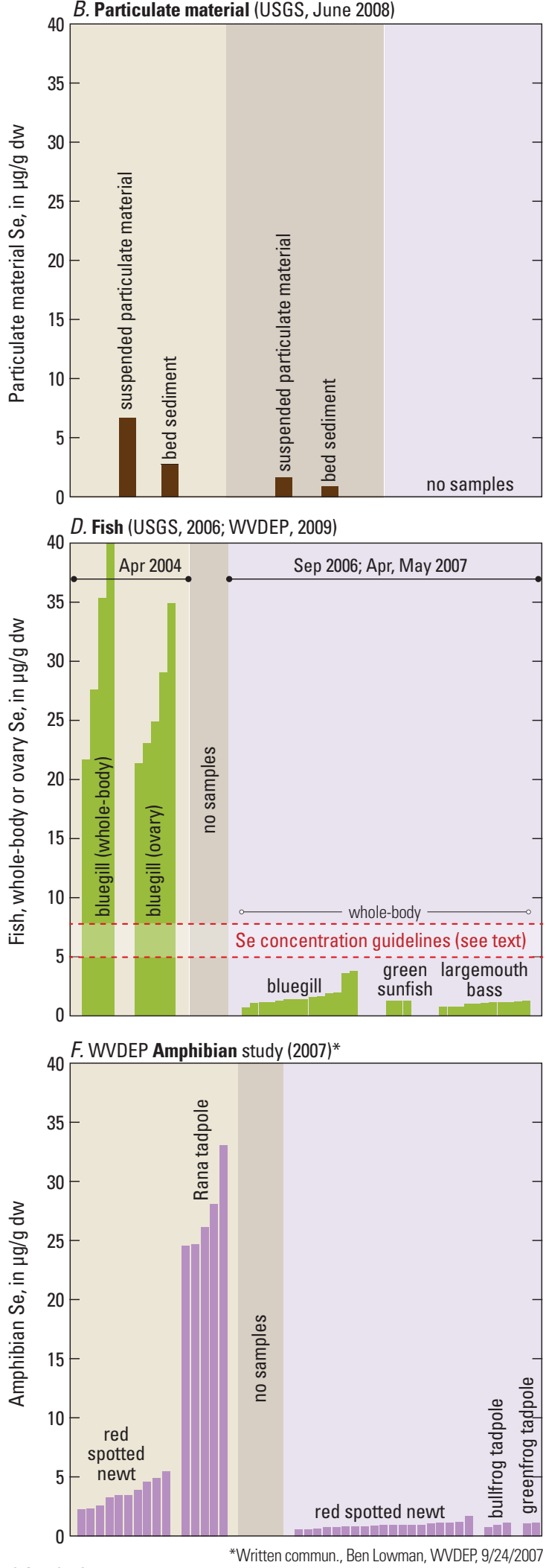

Figure 8. Concentrations of Se in food webs (2004-2008) for the Upper Mud River Reservoir and Plum Orchard Lake (reference site). $A$, Data for Se in water-column. Bar graphs showing $S e$ in $(B)$ particulate material, $(C)$ invertebrates, $(D$ and $E)$ fish, and $(F)$ amphibians. 


\section{Food Web: Invertebrates, Fish, and Amphibians}

Food-web sampling in earlier studies of the Upper Mud River Reservoir and a reference lake (Plum Orchard Lake) assessed Se concentrations in invertebrates (wb except for snail and clam where soft tissue only was analyzed), fish (wb or ovary), and amphibians (wb) (U.S. Geological Survey, 2008; WVDEP 2009, 2010) (fig. 8C-F). Created in 1962, Plum Orchard Lake is a 202-acre impoundment in the Upper Kanawha watershed. The WVDEP selected this site as a reference lake because the location had only minor upstream disturbance from mining. In total, data for both these impoundments are a compilation of samples collected from 2004 through 2007 (U.S. Geological Survey, 2006, 2008; WVDEP, 2009, 2010) and, thus, do not provide an optimally temporally matched dataset. However, these Se concentrations are informative because they illustrate a range of concentrations within impoundment ecosystems ranging from some minimally affected by coal mining effluents to one approximately 15 miles downstream of the Hobet Mining Complex. Mean Se concentrations (dw) for the Plum Orchard Lake ecosystem (fig. $8 A-F$ ) were:

- water-column $-<1 \mu \mathrm{g} / \mathrm{L}$;

- invertebrates - dragonfly $(\mathrm{n}=1), 1.9 \mu \mathrm{g} / \mathrm{g}$; crayfish, 2.0 $\mu \mathrm{g} / \mathrm{g}$; snail, $3.8 \mu \mathrm{g} / \mathrm{g}$;

- fish (wb) -bluegill sunfish, $1.7 \mu \mathrm{g} / \mathrm{g}$; green sunfish, 1.3 $\mu \mathrm{g} / \mathrm{g}$; largemouth bass, $1.1 \mu \mathrm{g} / \mathrm{g}$; and

- amphibians-bullfrog (Rana catesbeiana) and greenfrog (Rana clamitans) tadpoles, $1.0 \mu \mathrm{g} / \mathrm{g}$; red spotted newt, $0.97 \mu \mathrm{g} / \mathrm{g}$.

These food-web Se concentrations are similar to Se concentrations reported for other minimally affected sites (U.S. Department of Interior, 1998). The highest Se concentration being seen in snail among the taxa sampled is consistent with trophic transfer for benthic invertebrates (Presser and Luoma, 2010a).

Mean Se concentrations for the Upper Mud River Reservoir ecosystem (fig. 8A-F) were considerably higher:

- dissolved-3.6 $\mu \mathrm{g} / \mathrm{L}$;

- suspended particulate material $-6.7 \mu \mathrm{g} / \mathrm{g} \mathrm{dw}(\mathrm{n}=1)$;

- invertebrates - dragonfly, $16.5 \mu \mathrm{g} / \mathrm{g}$; crayfish, $10.2 \mu \mathrm{g} / \mathrm{g}$; clam (Corbicula fluminea), $30.6 \mu \mathrm{g} / \mathrm{g}$; snail (Planorbidae, $\mathrm{n}=1), 36.6 \mu \mathrm{g} / \mathrm{g}$;

- fish—bluegill sunfish, $25.3 \mu \mathrm{g} / \mathrm{g}$; green sunfish, 19.9 $\mu \mathrm{g} / \mathrm{g}$; largemouth bass, $25.3 \mu \mathrm{g} / \mathrm{g}$; and

- amphibians—Rana tadpole, $27.3 \mu \mathrm{g} / \mathrm{g}$; red spotted newt (Notophthalmus viridescens), $3.7 \mu \mathrm{g} / \mathrm{g}$

Mean Se concentration in all species of fish tested in the Upper Mud River Reservoir exceeded the proposed USEPA fish-tissue criterion of $7.9 \mu \mathrm{g} / \mathrm{g}$ (wb dw) (WVDEP, 2009). Dietary Se guidelines assumed here for illustration were exceeded by all invertebrate samples, with the maximum Se concentration in $C$. fluminea exceeding the higher illustrated guideline by 5.4 -fold (fig. $8 C$ ). In terms of Se toxicity to amphibians (tadpoles, $33 \mu \mathrm{g} / \mathrm{g}$ wb dw maximum), adult eastern narrow-mouth toads (Gastrophryne carolinensis) were found to transfer significant amounts of Se into their eggs, and hatchlings exhibited axial and craniofacial abnormalities similar to those attributed to Se (Hopkins and others, 2006). Larval bullfrogs (Rana catesbeiana) with tissue Se concentrations of $20-28 \mu \mathrm{g} / \mathrm{g} \mathrm{dw}$, an amount exceeded in tadpoles of the Upper Mud River Reservoir, also showed axial malformations, along with exhibiting abnormal swimming behavior (Hopkins and others, 2000). However, in both cited studies, the sites were impacted by a mixture of contaminants (for example, arsenic, cadmium) in addition to Se.

\section{Fish}

Within a specified hydrologic type or location, fish species is a driver of Se bioaccumulation, which, in the modeling shown here, is based mainly on differences in a predator's dietary preferences (that is, the biodynamics of the invertebrate species that the predator chooses to eat).

In the absence of information on invertebrate food webs, as is the case in most of the studies compiled here, generalized feeding habit and a hierarchy of fish species' Se bioaccumulation can give insight into overall Se risk to fish at a specific site. Considering a maximum bioaccumulative potential of Se at a site as recorded in the Se concentrations of different fish species (for example, figs. 8E, 9B, and 9C) is an important outcome of assessment. This formalization and conceptualization of data allows comparison across hydrologic settings and seasons and informs modeling in terms of the totality of an ecosystem and fish community response to Se. Hypothetically, a comparative hierarchy of fish species at a specified site could reveal the influence of a combination of feeding variables: (1) a top predator (piscivore) could potentially accumulate more Se because of the inclusion of dietary items subjected to additional trophic steps that biomagnify Se; (2) a generalist feeder could potentially accumulate less Se because of its ability to feed from many sources of varying Se bioaccumulation; (3) an insectivore or molluscivore could potentially accumulate more Se because of a dedicated food source selection that depends on a relatively elevated trophic transfer; and (4) a herbivore could potentially accumulate less Se because of lower trophic level feeding (that is, no invertebrate feeding).

For example, at Belews Lake, North Carolina, 21 fish species ultimately were eliminated as a result of Se exposure from a coal-fired power plant. Eventually, all piscivores and insectivores were absent, with only three omnivores (common carp, catfish, and fathead minnows) surviving (Lemly, 1985; Young, and others, 2010). A hierarchy of fish species' Se bioaccumulation in the changing community structure was not directly addressed, but bluegill sunfish and largemouth bass were among the fish species bioaccumulating the most $\mathrm{Se}$ 
based on muscle Se (range of means: $70-80 \mu \mathrm{g} / \mathrm{g} \mathrm{dw}$ ) (Lemly, 1985). General ecological variables that also could affect the development of such a ranking include (1) the consistency of food availability and community structure across the time span of contamination and recovery; (2) the partitioning of Se in different tissues if the ranking was not determined on a wb basis. For example, in the case of Belews Lake, the predischarge fish community was dominated by bluegill sunfish, which were notably replaced by green sunfish during Se discharge. Red shiners also made up a large percentage of the altered fish community. A diverse, but changed, fish community was recorded 10 years postdischarge, with bluegill sunfish and gizzard shad prevalent. Hence, compiling and analyzing datasets across seasons and years can be challenging within changing or perturbed systems. As mentioned previously, the biodynamics of trophic transfer from diet to fish species varies considerably

\section{Upper Mud River Basin: river segments and tributaries-2005-2009}

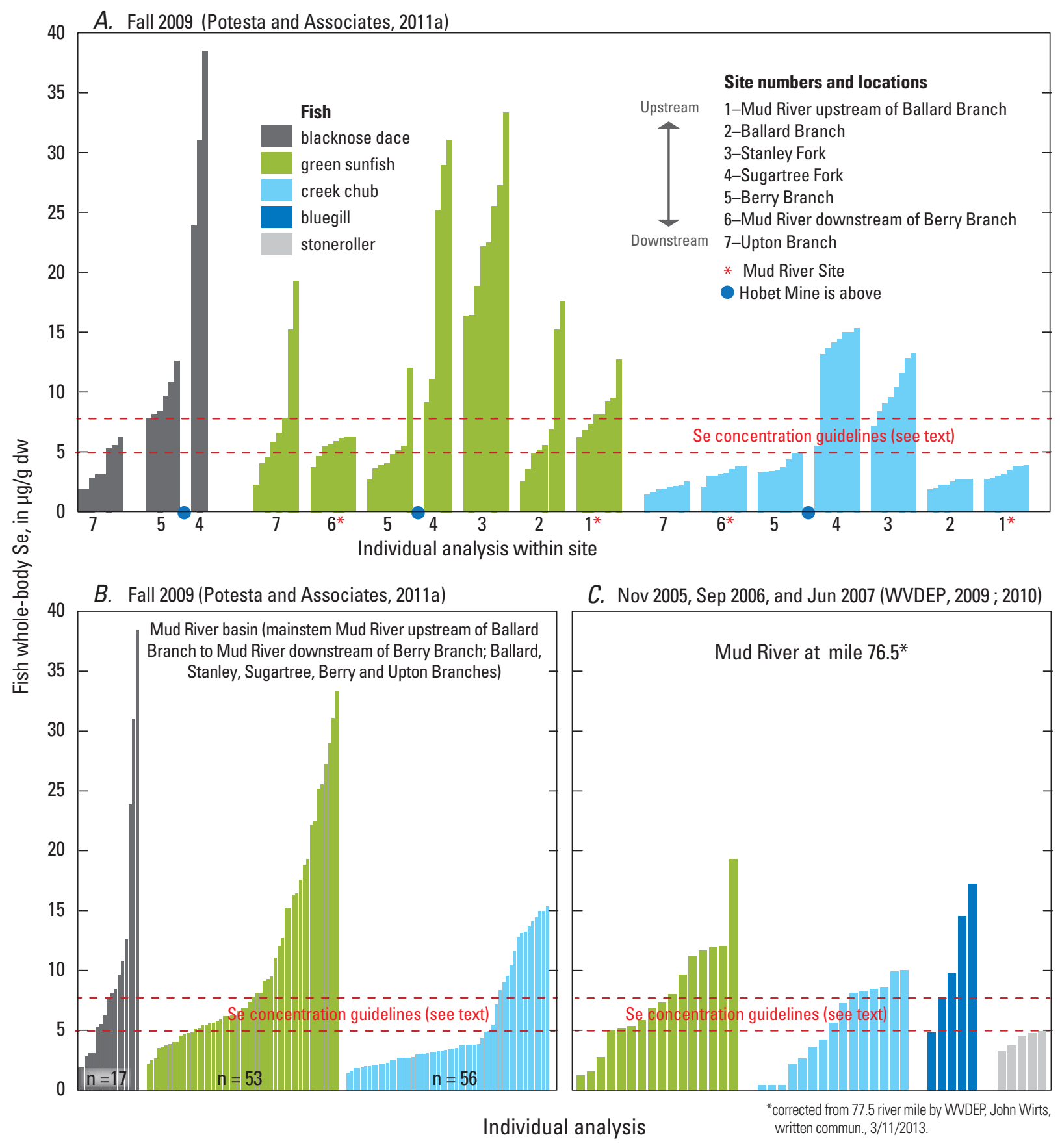

Figure 9. Bar graphs showing Se concentrations in fish for river segments and tributaries of the Upper Mud River basin in $(A$ and $B)$ fall 2009 and $(C)$ November 2005, September 2006, and June 2007. 
less than from diet to invertebrate taxa or species. However, for site-specific fish species, this variability may make an important difference in defining and choosing the overall food web to model for a watershed or fish community approach.

Lastly, in terms of a species' inherent sensitivity to Se toxicity, a limited number of fish species have been studied (Janz and others, 2010; Janz, 2012; DeForest and others, 2012). A comparison of threshold egg/ovary Se concentrations causing an increase in larval edema, lordosis, deformities, or mortality above different controls (that is, the no or lowest effect concentration, NOEC or LOEC; or a 10-percent effect concentration, EC10) has been performed in 12 fish species, including bluegill sunfish, largemouth bass, and several species of trout, where adequate data exist. Bluegill sunfish, for example, ranked differently in sensitivity, depending on the endpoint and methodology used to determine a toxicity threshold. In general however, bluegill sunfish ranked below (that is, are more sensitive than) several species of trout and northern pike; its sensitivity in relation to largemouth bass, however was variable (Janz and others, 2010).

\section{Upper Mud River Basin}

Fish Se concentrations (wb dw) for the Mud River Reservoir are displayed from minimum to maximum for an analyzed set of data specific to date and species (fig. $8 E$ ) to show the overall potential of the ecosystem (that is, hydrologic setting and food-web species) for Se bioaccumulation. The species maxima (bluegill sunfish, $60 \mu \mathrm{g} / \mathrm{g}$; green sunfish, 47 $\mu \mathrm{g} / \mathrm{g}$; largemouth bass, $36 \mu \mathrm{g} / \mathrm{g}$ ) give insight into the speciesspecificity that needs to be built into modeling to accurately predict observed Se concentrations for fish in these systems. Plots such as these, which utilize all available Se analyses across species and time periods for a site, give a visual record that is important to the ecosystem approach. The central tendency of such disparate datasets (that is, different numbers of fish collected over different seasons in different years) may be less useful in differentiating important species characteristics and temporal habitat variables that affect Se biodynamics. From such a data compilation, a hierarchy of Se bioaccumulation can be constructed for the Upper Mud River Reservoir during 2005-2008: bluegill sunfish > green sunfish > largemouth bass.

Selenium concentrations in fish sampled at stream sites in the Upper Mud River basin were compiled from studies conducted during 2005-2009 (WVDEP, 2009, 2010; Potesta and Associates, Inc., 2011a). Figure 9A shows Se concentrations specific to fish species for the Upper Mud River basin arranged by site from downstream to upstream. Fish from the Sugartree

Figure 10. Bar graphs showing Se concentrations in fish for $(A)$ Beech Creek and White Oak Creek, $(B)$ Jacks Branch mine drainage, and $(C)$ Conner Run and Little Scary Creek.
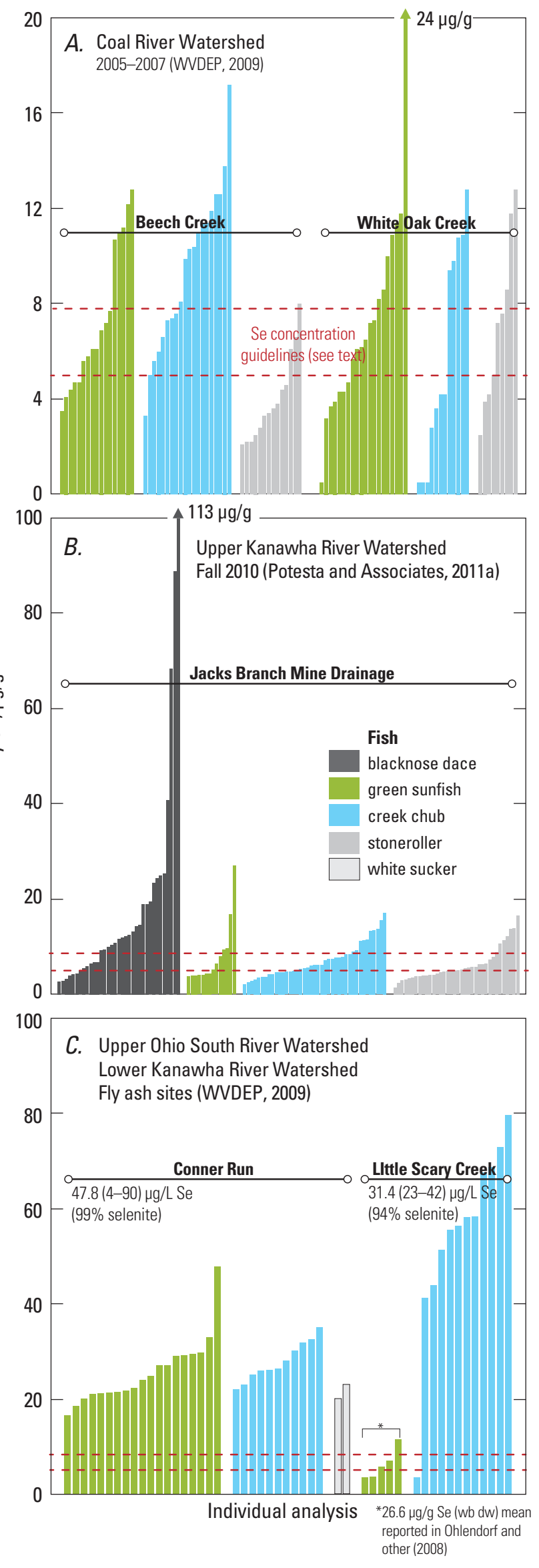
Branch and Stanley Fork sites showed the highest Se concentration. In figure 9B, data are shown from lowest to highest for each species at all sites combined, similar to the type of display discussed for figure $8 E$. Individual species maxima ( $w b \mathrm{dw}$ ) are: blacknose dace, $38.5 \mu \mathrm{g} / \mathrm{g}$; green sunfish, $33.4 \mu \mathrm{g} / \mathrm{g}$; and creek chub, $15.4 \mu \mathrm{g} / \mathrm{g}$. It should be noted that this study covered a broad reach of the river with varying proximity to $\mathrm{Se}$ sources (fig. $9 A$ versus fig. $9 B$ ).

Selenium concentration maxima ( $\mathrm{wb} \mathrm{dw}$ ) specific to fish species for the Mud River at mile 75.6 (fig. 9C) are: bluegill, $17.3 \mu \mathrm{g} / \mathrm{g}$; green sunfish, $19.4 \mu \mathrm{g} / \mathrm{g}$; creek chub, $10.1 \mu \mathrm{g} / \mathrm{g}$; and stoneroller, $5.0 \mu \mathrm{g} / \mathrm{g}$. These species maxima (figs. $9 B$ and $9 C$ ) quantify the overall potential of the river ecosystem for Se bioaccumulation for comparison to $\mathrm{Se}$ bioaccumulation displayed in figure $8 E$ for the reservoir ecosystem. For example, where comparisons are possible, the reservoir sunfish maxima are, in general, 2.4-3.5-fold higher than the maxima for sunfish in the Mud River at mile 75.6; and maxima for sunfish in the upper reaches of the Mud River are higher than the maxima at mile 75.6. Within the Upper Mud River hydrologic setting (figs. $9 B$ and $9 C$ ), the hierarchy of fish Se concentrations was blacknose dace $\geq$ bluegill sunfish, $>$ green sunfish $>$ creek chub $>$ stoneroller. Specifically for the river, maxima for sunfish are approximately 3.7 -fold higher than the maxima for stoneroller and 1.8-fold higher than for creek chub.

\section{Other Basins}

Streams affected by mountaintop coal mining and valley fills in the Coal River and Upper Kanawha River watersheds also were included in earlier studies. Studies of green sunfish, creek chub, and central stoneroller during 2005-2007 in Beech Creek and White Oak Creek (WVDEP, 2009) showed some definition between species (fig. 10A). Central stoneroller Se concentrations were considerably lower than green sunfish and creek chub within the Beech Creek basin. The range of Se concentrations in fish sampled at sites within the Jacks Branch Mine drainage (Potesta and Associates, Inc., 2011b) was influenced by the presence of blacknose dace that were inhabiting a pond within the drainage area (fig. 10B). Especially elevated Se concentration occurred in blacknose dace (maximum, $113 \mu \mathrm{g} / \mathrm{g}$ wb dw) within this hydrologic setting. Other species of fish at this ponded site were not sampled (or were not present), but sampling at other sites within the drainage area showed a maximum Se concentration in green sunfish of $27 \mu \mathrm{g} / \mathrm{g}$ (wb dw). Potesta and Associates, Inc. (2011b) noted the dominant species as mottled sculpin at several sites, but Se data were not given for this species.

Creeks that receive discharges from seleniferous fly-ash disposal ponds represent an additional affected ecosystem for Se characterization based on data from earlier studies. Sampling at Conner Run (Upper Ohio River South watershed) and Little Scary Creek (Lower Kanawha River watershed) showed the effect on Se concentrations in fish as a predominance of dissolved selenite (maximum 99 percent selenite) is efficiently transformed at the base of the food web and amplified through food webs (fig. 10C) (WVDEP, 2009). Especially elevated Se concentrations in creek chub (Little Scary Creek, maximum 80 $\mu \mathrm{g} / \mathrm{g}$ wb dw) and green sunfish (Conner Run, $48 \mu \mathrm{g} / \mathrm{g}$ wb dw) were found during September 2006. For comparison, general conditions reported in 2007 were a water-column for Little Scary Creek containing $20 \mu \mathrm{g} / \mathrm{L}$ with 82 percent selenite and, for Conner Run, $143 \mu \mathrm{g} / \mathrm{L}$ and 90 percent selenite (Reash, 2012). Geometric mean Se concentrations (wb dw) reported from this later study for Little Scary Creek were:

- $55 \mu \mathrm{g} / \mathrm{g}$ blacknose dace;

- $28 \mu \mathrm{g} / \mathrm{g}$ chub;

- $27 \mu \mathrm{g} / \mathrm{g}$ green sunfish;

- $20 \mu \mathrm{g} / \mathrm{g}$ hybrid sunfish; and

- $14 \mu \mathrm{g} / \mathrm{g}$ white crappie.

Geometric mean Se concentrations ( $w b \mathrm{dw}$ ) for fish at Conner Run during 2007 (Reash, 2012) were comparable to those at Little Scary Creek:

- $57 \mu \mathrm{g} / \mathrm{g}$ green sunfish;

- $41 \mu \mathrm{g} / \mathrm{g}$ longear sunfish;

- $26 \mu \mathrm{g} / \mathrm{g}$ bluegill sunfish;

- $19 \mu \mathrm{g} / \mathrm{g}$ white bass; and

- $12 \mu \mathrm{g} / \mathrm{g}$ spotted bass.

It should be noted that for Little Scary Creek, Se concentrations reported in 2006 for green sunfish (mean $6.2 \mu \mathrm{g} / \mathrm{g} \mathrm{wb} \mathrm{dw}$ ) (fig. 10C) were considered questionable, because a mean concentration of $26.6 \mu \mathrm{g} / \mathrm{g}$ ( $\mathrm{wb} \mathrm{dw}$ ) was measured in 2007 (Ohlendorf and others, 2008; Reash, 2012).

\section{Sampled Ecosystems: Site Schematics and Assessed Ecosystems}

\section{Basin Ecosystem Schematics}

Within this regional context, the USGS assessed stream ecosystems of southern West Virginia in the Big Coal, Little Coal, Gauley, Lower Guyandotte, Elk, and Upper Kanawha watersheds in 2010 and 2011 (table 2; fig. 4). Sites in the Upper Mud River, Twentymile Creek, and Clear Fork basins are represented schematically in figures 11-14. Figure 15 depicts sampling by the USGS in 2011 at Cabin Creek, Beech Creek, and Birch River. Within this spatial framework, a compilation of tables specific to location and date show foodweb data from this study and earlier USGS studies in 20062008 (U.S. Geological Survey, 2006, 2008). Data also are included from studies in these same basins by (1) WVDEP in 2005-2007 (WVDEP, 2009, 2010); (2) Potestaand Associates, Inc. in 2008-2011 (Potesta and Associates, Inc., 2011a, 
b); and (3) Lindberg and others (2011). Emphasis here is on food-web Se data and data selected for use in ecosystem-scale Se modeling (that is,, matched data for 2011). For fish, both wb and ovary Se concentrations are provided where they were available. Suspended-particulate-material Se concentrations for USGS sites are not available for 2010. Dissolved Se concentrations for USGS sites during 2010 are compiled and discussed later (see especially figures 16-19 and figure 21). Sampling of both in-stream and off-stream ecosystems (1) helps contrast the effects of such variables as water residence time and stream depositional opportunities; and (2) documents the scope and specificity of food-web species (figs. 11-15).

The Upper Mud River basin ecosystem is affected by the Hobet Mining Complex (figs. 11 and 12). Compiled datasets characterize sites both downstream (fig. 11) and upstream (fig. 12) of USGS sites that were sampled in 2010 and 2011. For example, results are shown from sampling of the Upper Mud River Reservoir as part of the basin hydrologic system where Se from the Upper Mud River enters a downstream slow moving, deep-water environment (fig. 11). An upstream schematic depicts the river system and its tributaries that are directly adjacent to Se source areas of the basin (fig. 12). Besides compiled data, data from Lindberg and others (2011) are displayed on the upstream schematic itself. These authors reported that Se concentrations (1) within the main-stem of the river increased overall from $1.1 \mu \mathrm{g} / \mathrm{L}$ upstream to 19.1 $\mu \mathrm{g} / \mathrm{L}$ downstream; and (2) among river tributaries reached a maximum of $35.7 \mu \mathrm{g} / \mathrm{L}$ during the 7 -month (May-December 2010) sampling period. Sampling was not performed during January through April, thus limiting any observation of peaks (that is, a flush of $\mathrm{Se}$ ) in early spring.

The Clear Fork and Cabin Creek basins are affected by the Catenary Mine Complex (fig. 13). The Twentymile Creek basin is affected by the Nicholas Energy Complex (fig. 14). Beech Creek and the Birch River basins (fig. 15) were less intensively sampled, but the sampling added spatial detail for the extent of Se contamination. Beech Creek is affected by the Beech Creek Surface Mine and the Birch River is affected by the Birch River Mine (West Virginia Office of Miners' Health Safety and Training, 2009, 2013).

\section{Assessed Food Webs: Water, Particulate Material, Invertebrate, and Fish}

For USGS sites in 2010 and 2011, food-web sampling assessed Se concentrations within the media progression of dissolved, suspended particulate material, invertebrate, and fish (wb and ovary) (figs. 16-19). Measured selenium concentrations are displayed from lowest to highest of composite or singletaxon samples, as noted before, to show the overall potential of an ecosystem for Se bioaccumulation. Fish Se concentrations also are available for different seasons (spring 2010, fall 2010, and spring 2011) from seven sites (fig. 20). Appendix 2 contains a complete listing of wb and ovary Se concentrations, with corresponding fish weight, standard length, and total length.
Examples of dietary (4.5 and 7.2 $\mu \mathrm{g} / \mathrm{g} \mathrm{dw})$ and fish-tissue (5.0 and $7.9 \mu \mathrm{g} / \mathrm{g} \mathrm{wb} \mathrm{dw}$ ) Se guidelines are noted for reference on figures 16-19 (USEPA, 1987, 2004; Skorupa and others, 2004; Presser and Luoma, 2006, 2010a,b, 2013). Additionally, the British Columbia Ministry of Environment recently proposed an egg/ovary-tissue Se guideline of $11 \mu \mathrm{g} / \mathrm{g}$ dw (British Columbia Ministry of Environment, 2012), and the USFWS calculated an egg Se concentration for maximum fully normal brown trout fry of $6.5 \mu \mathrm{g} / \mathrm{g} \mathrm{dw}$ (USFWS, 2012b). This threshold is referenced to a 10 percent effect concentration (EC10). As discussed later, any criterion, guideline, or target may be used in modeling to predict effects on predators, and, whatever the choice, the model can predict its implications. These values are given here for illustration purposes, with the recognition that debate is still occurring about determining critical tissue values that relate bioaccumulated Se concentrations to toxicity in predators. Thus, figures 16-19 give a comprehensive, detailed view of assessed Se concentrations in each basin for 2010 and 2011with reference to a range of tissue Se guidelines.

In the discussion of Se concentrations below, comparative analysis and modeling of species and tissue Se concentrations (dietary and fish wb) among specific basin sites were made based on temporally matched datasets collected for each site during April or May of 2011 (table 3). Paired samples for dissolved and suspended-particulate-material Se concentrations were either collected earlier (that is, February and March 2011) or later (June 2011) than the collection for tissues, thus not being precisely temporally matched to the invertebrate and fish collection (table 3). As mentioned previously, matched datasets are key to initiation of modeling and allow ecologically consistent predictions (Presser and Luoma, 2010a). Furthermore, not all study sites could be included in the comparative analysis, and consequently in the modeling or validation of modeling that follows below, because of a lack of (1) invertebrate or fish samples during 2011 (Mud River lower, Upton Branch of the Mud River, Clear Fork lower, and Twentymile Creek lower) or (2) a suspended-particulate-material sample of enough weight for analysis (White Oak Creek, Beech Creek, and Birch Creek) (table 3). Additionally, fish community data collected in April 2011 at Twentymile Creek upper, White Oak Creek, Seng Creek, Clear Fork upper, left fork Mud River, Cabin Creek, and Beech Creek are matched temporally to fish and invertebrate Se concentrations, but physical habitat data were collected only once as a snapshot-in-time during July 2010 (table 3).

\section{Comparative Analysis of Selenium Concentrations and Species: Invertebrates and Fish (Whole-Body)}

For the Upper Mud River basin ecosystem (fig. 16), the left fork of the river showed a mean invertebrate Se concentration of $3.0 \mu \mathrm{g} / \mathrm{g} \mathrm{dw}$. Selenium concentrations (dw) for aquatic insects were: mayfly, $1.9 \mu \mathrm{g} / \mathrm{g}$; chironomid, 2.0 $\mu \mathrm{g} / \mathrm{g}$; and dragonfly, $5.0 \mu \mathrm{g} / \mathrm{g}$. The mean creek chub Se concentration for this site was $2.4 \mu \mathrm{g} / \mathrm{g}$ (wb dw), with a range 


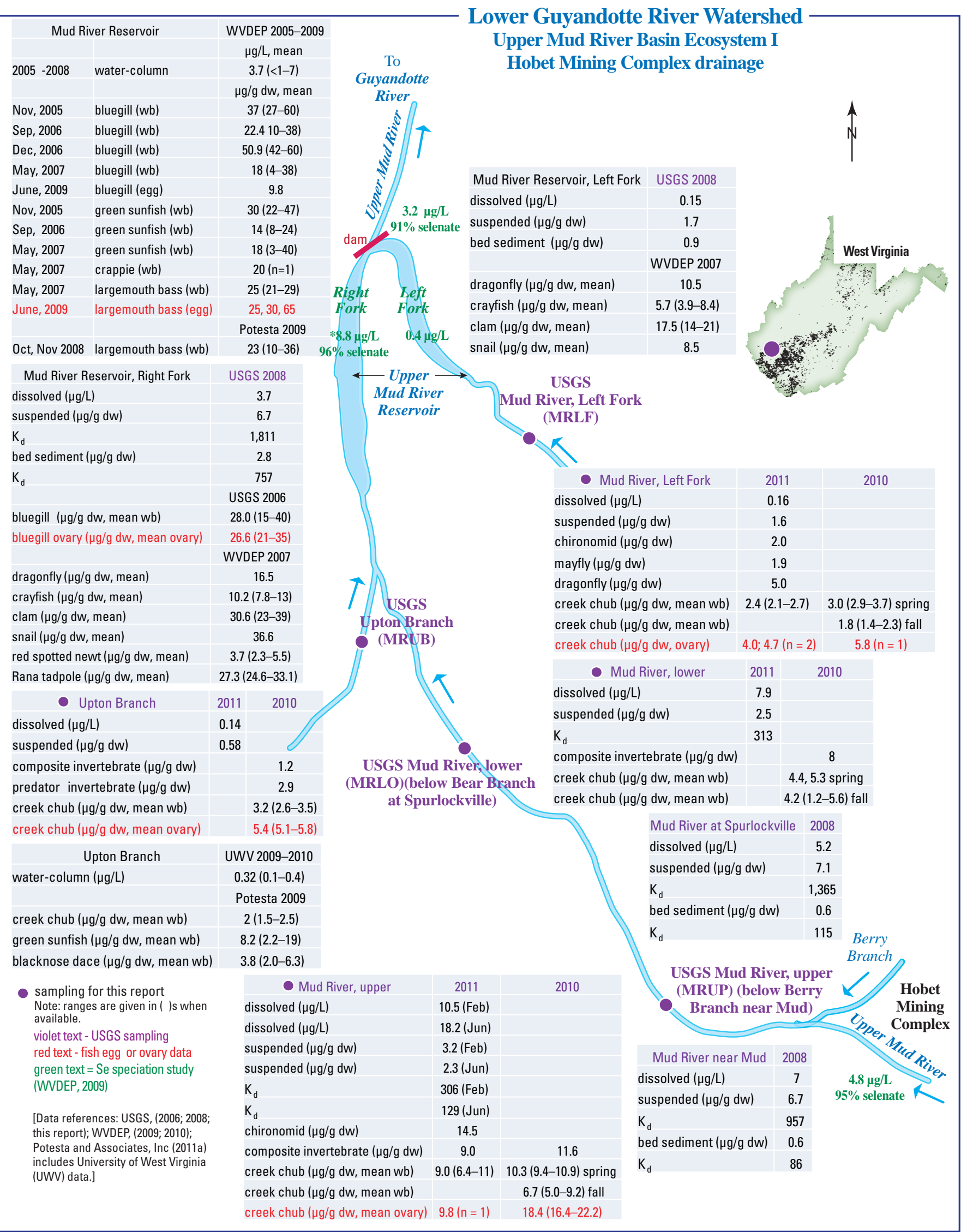

Figure 11. Schematic map of USGS sampling sites (purple dots) and compiled Se data for the Upper Mud River Basin Ecosystem I during 2010-2011. Available Se data from other studies are also shown. Dates on figure are dates of sampling. 


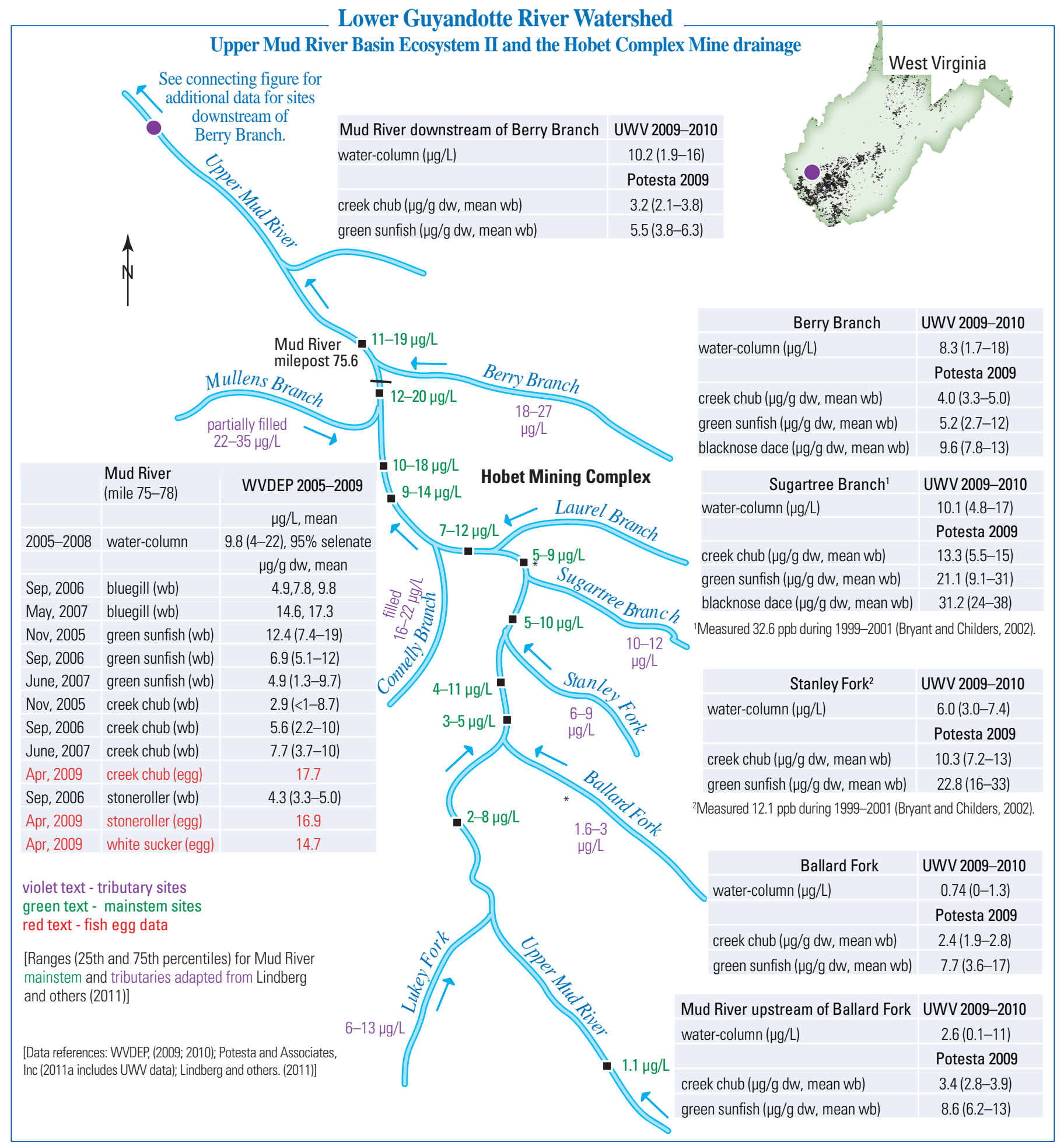

Figure 12. Schematic map and compiled Se from various studies for the Upper Mud River Basin Ecosystem II. Dates on figure are dates of sampling. 


\section{Big Coal River Watershed}

Clear Fork Basin Ecosystem

Catenary Mine Complex Drainage Clear Fork at Whitesville \#03198350

Sycamore Creek

dissolved ( $\mu \mathrm{g} / \mathrm{L})$

suspended $(\mu \mathrm{g} / \mathrm{g} \mathrm{dw})$

mayfly $(\mu \mathrm{g} / \mathrm{g} d w)$

stonefly $(\mu \mathrm{g} / \mathrm{g} \mathrm{dw})$

predator insect $(\mu \mathrm{g} / \mathrm{g} \mathrm{dw})$

composite invertebrate $(\mu \mathrm{g} / \mathrm{g} \mathrm{dw})$

creek chub ( $\mu \mathrm{g} / \mathrm{g} \mathrm{dw}$, mean wb)

creek chub ( $\mu \mathrm{g} / \mathrm{g} d w$, mean wb)

creek chub ( $\mu \mathrm{g} / \mathrm{g} \mathrm{dw}$, mean ovary) 5.4 (4.5-6.9

Sycamore Creek

water-column $(\mu \mathrm{g} / \mathrm{L})$

creek chub (wb)

creek chub (Apr, 2007)

stoneroller (wb)

\section{WVDEP 2005-2007 $<1$ $\mu \mathrm{g} / \mathrm{g} \mathrm{dw}$, mean $1.3(<1-2.7)$ (outlier, deleted) $0.9(<1-2.1)$}

sampling for this report violet text - USGS sites red text - fish egg or ovary data [data references: USGS, (this report); WVDEP, (2009; 2010)]

Sycamore Creek

(CFSC)

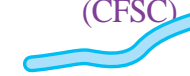

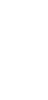

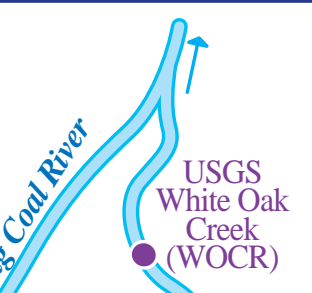

\begin{tabular}{|l|l|}
\hline White Oak Creek & 20 \\
\hline dissolved $(\mu \mathrm{g} / \mathrm{L})$ & 24.2 \\
\hline
\end{tabular}

caddisfly $(\mu \mathrm{g} / \mathrm{g} \mathrm{dw})$

dobsonfly $(\mu \mathrm{g} / \mathrm{g} \mathrm{dw})$

creek chub ( $\mu \mathrm{g} / \mathrm{g} \mathrm{dw}$, mean wb) 6.1 (4.3-7.8)

stoneroller ( $\mu \mathrm{g} / \mathrm{g} \mathrm{dw}$, mean wb) $6.0(4.1-5.6)$

(WOCR)

water-column $(\mu \mathrm{g} / \mathrm{L})$

green sunfish ( $\mu \mathrm{g} / \mathrm{g} \mathrm{dw}$, mean wb)

creek chub ( $\mu \mathrm{g} / \mathrm{g} \mathrm{dw}$, mean wb)

stoneroller ( $\mu \mathrm{g} / \mathrm{g} \mathrm{dw}$, mean wb)

WVDEP 2005-2007

15.8 (8-27), 94\% selenate $\mu \mathrm{g} / \mathrm{g} \mathrm{dw}$, mean

$7.4(<1-23.7)$

$5.8(<1-12.8)$

$7.1(2.5-12.8)$

\begin{tabular}{l|l} 
- Seng Creek & 2011 \\
\hline
\end{tabular}

\begin{tabular}{|l|l|}
\hline dissolved $(\mu \mathrm{g} / \mathrm{L})$ & 23.3 \\
\hline
\end{tabular}

\begin{tabular}{l|l|l|} 
suspended $(\mu \mathrm{g} / \mathrm{g} \mathrm{dw})$ & 4.2 \\
\hline
\end{tabular}

\begin{tabular}{ll}
$\mathrm{K}_{\mathrm{d}}$ & 180 \\
\hline
\end{tabular}

\begin{tabular}{|l|l|} 
stonefly $(\mu \mathrm{g} / \mathrm{g} \mathrm{dw})$ & 10.8
\end{tabular}

caddisfly $(\mu \mathrm{g} / \mathrm{g} \mathrm{dw}) \quad 11.2$

creek chub ( $\mu \mathrm{g} / \mathrm{g} \mathrm{dw}$, mean wb) $\quad 8.1(5.4-10)$

creek chub ( $\mu \mathrm{g} / \mathrm{g} \mathrm{dw}$, ovary) $\quad 9.4 ; 12.3(\mathrm{n}=2)$

\begin{tabular}{l|c}
\multicolumn{1}{c|}{ Seng Creek } & WVDEP 2005-2009 \\
\hline water-column $(\mu \mathrm{g} / \mathrm{L})$ & $27.5(15-42), 96 \%$ selenate \\
\hline creek chub $(\mu \mathrm{g} / \mathrm{g} \mathrm{dw}$, mean $w \mathrm{~b})$ & $\mu \mathrm{g} / \mathrm{g} \mathrm{dw}$, mean \\
\hline creek chub $(\mu \mathrm{g} / \mathrm{g} \mathrm{dw}$, mean egg) & $8.2(4.8-14.7)$ \\
\hline stoneroller $(\mu \mathrm{g} / \mathrm{g} \mathrm{dw}$, egg) & $19.9(16.4-23.8)$ \\
\hline
\end{tabular}

USGS

Clear Fork, lower

(CFLO)

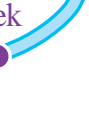

stoneroller ( $\mu \mathrm{g} / \mathrm{g} d w$, mean $w b)$

stoneroller ( $\mu \mathrm{g} / \mathrm{g} \mathrm{dw}$, mean ovary)
$\mathrm{K}_{\mathrm{d}}$

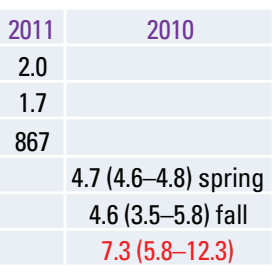

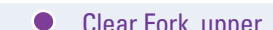

- Clear Fork, upper

dissolved ( $\mu \mathrm{g} / \mathrm{L})$ suspended $(\mu \mathrm{g} / \mathrm{g} \mathrm{dw})$ chironomid $(\mu \mathrm{g} / \mathrm{g} \mathrm{dw})$ composite invertebrate $(\mu \mathrm{g} / \mathrm{g} \mathrm{dw})$ creek chub ( $\mu \mathrm{g} / \mathrm{g} \mathrm{dw}$, mean wb) creek chub ( $\mu \mathrm{g} / \mathrm{g} \mathrm{dw}$, mean wb) creek chub ( $\mathrm{gg} / \mathrm{g} \mathrm{dw}$, mean ovary) $3.9(3.3-4.3) \quad 3.9(3.1-5.4)$

Figure 13. Schematic map of USGS sampling sites (purple dots) and compiled Se data for the Clear Fork Basin Ecosystem during 2010-2011. Available Se data from other studies are also shown. Dates on figure are dates of sampling. 


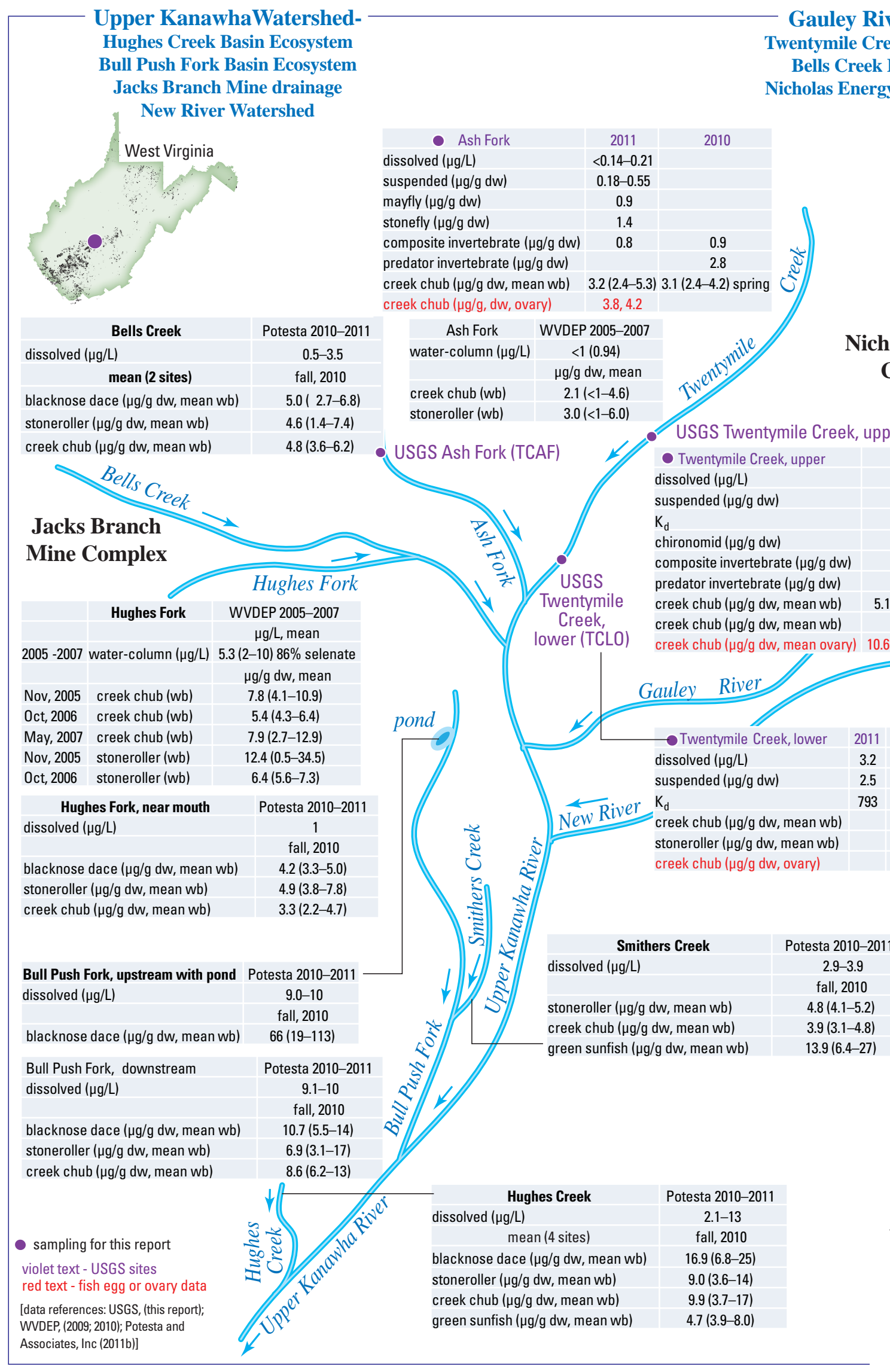

Figure 14. Schematic map of USGS sampling sites (purple dots) and compiled Se data for the Twentymile Creek Basin Ecosystem during 2010-2011. Available Se data from other studies are also shown. Dates on figure are dates of sampling. 


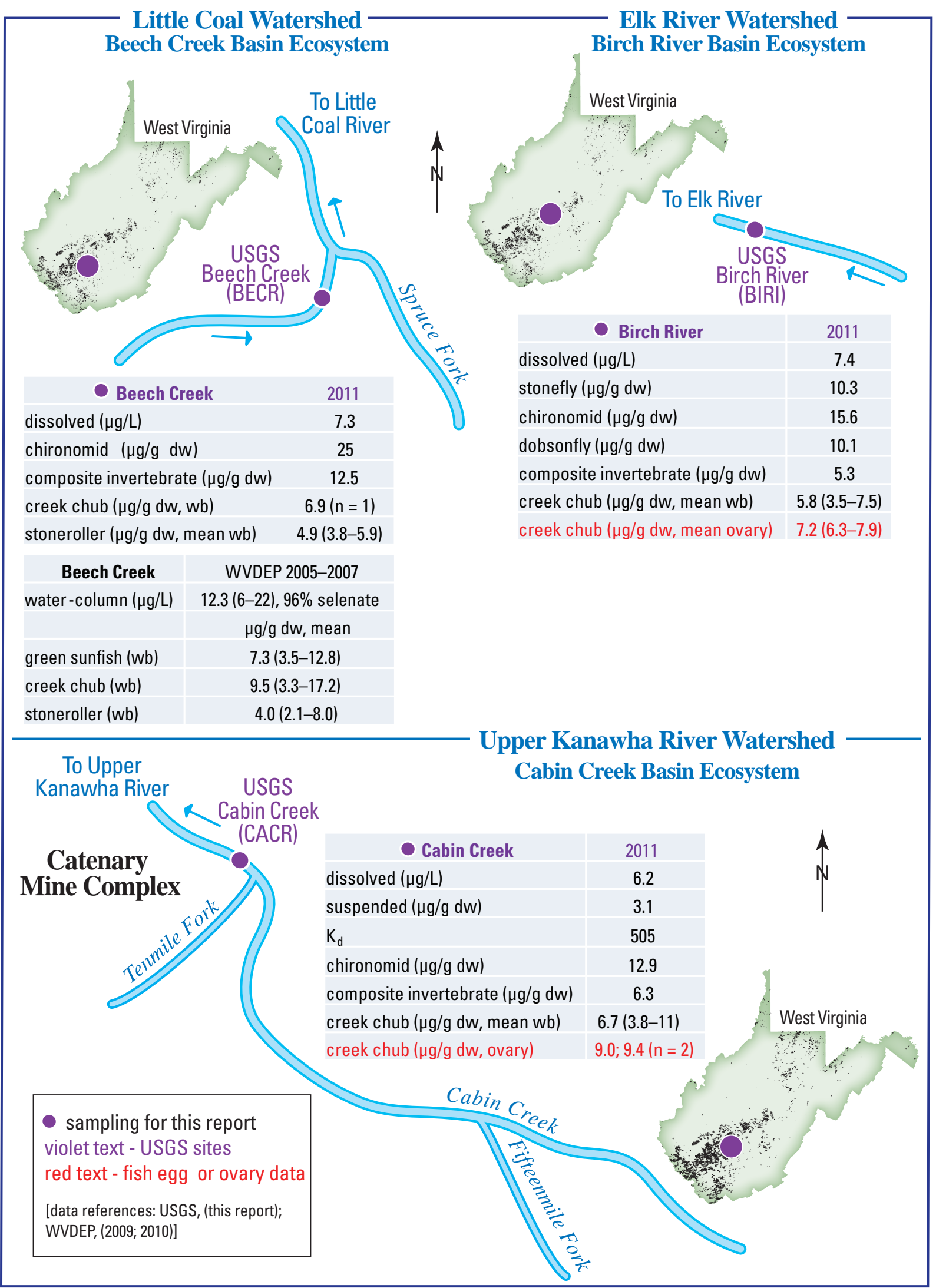

Figure 15. Schematic map of USGS sampling sites (purple dots) and compiled Se data for Beech Creek, Cabin Creek, and the Birch River during 2010-2011. Available Se data from other studies are also shown. Dates on figure are dates of sampling. 
of $2.1-2.7 \mu \mathrm{g} / \mathrm{g}$. The upstream site (Mud River upper) showed a composite invertebrate Se concentration of $9.0 \mu \mathrm{g} / \mathrm{g} \mathrm{dw}$ and a chironomid Se concentration of $14.5 \mu \mathrm{g} / \mathrm{g}$ dw. The mean creek chub Se concentration was $9.0 \mu \mathrm{g} / \mathrm{g}$ dw for this site, with a range of 6.4-11.1 $\mu \mathrm{g} / \mathrm{g} \mathrm{dw}$. As discussed earlier (see fig. 9C), sampling of the Upper Mud River at mile 75.6 during 2005-2007 showed the following means and ranges (wb dw) for different fish species: bluegill, $10.9 \mu \mathrm{g} / \mathrm{g}(4.9-17.3 \mu \mathrm{g} / \mathrm{g})$; green sunfish, $7.9 \mu \mathrm{g} / \mathrm{g}(1.3-19.4 \mu \mathrm{g} / \mathrm{g})$; creek chub, $5.4 \mu \mathrm{g} / \mathrm{g}$ (0.5-10.1 $\mu \mathrm{g} / \mathrm{g})$; and stoneroller, $4.3 \mu \mathrm{g} / \mathrm{g}(3.3-5.0 \mu \mathrm{g} / \mathrm{g})$.

Selenium concentrations for clam, snail, crayfish, and dragonfly were available for the Upper Mud River Reservoir ecosystem during 2005-2007 (WVDEP, 2009) (figs. 8 and 11) for comparison to the river basin ecosystem. For the right fork of the reservoir, mean invertebrate Se concentrations (dw) sampled in 2007 were: crayfish, $10.2 \mu \mathrm{g} / \mathrm{g}$; and clam (C. fluminea), 30.6 $\mu \mathrm{g} / \mathrm{g}$. Selenium concentrations (dw) for dragonfly and snail were 16.5 and $36.6 \mu \mathrm{g} / \mathrm{g}$, respectively. Species and Se concentrations (mean and range, wb dw) for fish measured during 2005-2007 were: bluegill sunfish, $25.3 \mu \mathrm{g} / \mathrm{g}(3.9-60 \mu \mathrm{g} / \mathrm{g})$; green sunfish, $19.9 \mu \mathrm{g} / \mathrm{g}(3.2-47 \mu \mathrm{g} / \mathrm{g})$; and largemouth bass, $25.3 \mu \mathrm{g} / \mathrm{g}(21-29$ $\mu \mathrm{g} / \mathrm{g})$. Sampling in April 2006 showed a mean bluegill sunfish Se concentration of $28 \mu \mathrm{g} / \mathrm{g}$ (wb dw), with a range of $15-40 \mu \mathrm{g} / \mathrm{g}$ (U.S. Geological Survey, 2006).

For the Clear Fork basin ecosystem (fig. 17), White Oak and Seng Creeks showed similar mean invertebrate Se concentrations of approximately $11 \mu \mathrm{g} / \mathrm{g}$ dw. Selenium concentrations (dw) for aquatic insects were: dobsonfly, 9.0 $\mu \mathrm{g} / \mathrm{g}$; caddisfly, $11.2 \mu \mathrm{g} / \mathrm{g}$ and $12.6 \mu \mathrm{g} / \mathrm{g}$; and stonefly, $10.8 \mu \mathrm{g} / \mathrm{g}$. The mean creek chub Se concentration for White Oak Creek was $6.0 \mu \mathrm{g} / \mathrm{g}$ (wb dw), with a range of 4.1-9.6 $\mu \mathrm{g} / \mathrm{g}$. Stoneroller also was present at this site, with a mean Se concentration of $6.1 \mu \mathrm{g} / \mathrm{g}(\mathrm{wb} \mathrm{dw})$ and a range of $4.3-7.8 \mu \mathrm{g} / \mathrm{g}$. The mean creek chub Se concentration at Seng Creek was higher than that at White Oak $(8.1 \mu \mathrm{g} / \mathrm{g}$ wb dw), with a wider range of 5.4-10.3 $\mu \mathrm{g} / \mathrm{g}$. Sycamore Creek showed a composite invertebrate Se concentration of $3.9 \mu \mathrm{g} / \mathrm{g} \mathrm{dw}$. Selenium concentrations for aquatic insects were: mayfly, $2.4 \mu \mathrm{g} / \mathrm{g}$; and stonefly, $4.2 \mu \mathrm{g} / \mathrm{g}$. For this site, the mean creek chub Se concentration was $2.9 \mu \mathrm{g} / \mathrm{g}$ (wb dw), with a range of 1.8-3.6 $\mu \mathrm{g} / \mathrm{g}$. Clear Fork upper showed a composite invertebrate Se concentration of $4.7 \mu \mathrm{g} / \mathrm{g} \mathrm{dw}$ and a Se concentration of $3.8 \mu \mathrm{g} / \mathrm{g} \mathrm{dw}$ for chironomid. For this site, the mean creek chub Se concentration was $2.5 \mu \mathrm{g} / \mathrm{g}$ (wb dw), with a range of $2.1-2.6 \mu \mathrm{g} / \mathrm{g}$.

For the Twentymile Creek basin ecosystem (fig. 18), Ash Fork showed a composite invertebrate Se concentration of $0.8 \mu \mathrm{g} / \mathrm{g} \mathrm{dw}$. Selenium concentrations for aquatic insects were: mayfly, $0.9 \mu \mathrm{g} / \mathrm{g}$; and stonefly, $1.4 \mu \mathrm{g} / \mathrm{g}$. The mean creek chub Se concentration was $3.2 \mu \mathrm{g} / \mathrm{g}$ (wb dw) for this site, with a range of $2.4-5.3 \mu \mathrm{g} / \mathrm{g}$. Twentymile Creek upper showed a composite invertebrate Se concentration of $5.2 \mu \mathrm{g} / \mathrm{g} \mathrm{dw}$ and a Se concentration of $7.5 \mu \mathrm{g} / \mathrm{g} \mathrm{dw}$ for chironomid. The mean creek chub Se concentration was $5.1 \mu \mathrm{g} / \mathrm{g}$ (wb dw) for this site, with a range of $4.6-6.1 \mu \mathrm{g} / \mathrm{g}$.

For those sites documented in figure 19, Cabin Creek showed a composite invertebrate Se concentration of $6.3 \mu \mathrm{g} / \mathrm{g}$ $\mathrm{dw}$ and a Se concentration of $12.9 \mu \mathrm{g} / \mathrm{g} \mathrm{dw}$ for chironomid. The mean creek chub Se concentration was $6.7 \mu \mathrm{g} / \mathrm{g}$ (wb dw) for this site, with a range of 3.8-11.2 $\mu \mathrm{g} / \mathrm{g}$. Beech Creek showed a composite invertebrate Se concentration of $12.5 \mu \mathrm{g} / \mathrm{g} \mathrm{dw}$, and a Se concentration of $25 \mu \mathrm{g} / \mathrm{g}$ for chironomid. The mean stoneroller Se concentration was $4.9 \mu \mathrm{g} / \mathrm{g}$ (wb dw) for this site, with a range of 3.8-5.9 $\mu \mathrm{g} / \mathrm{g}$. A creek chub Se concentration of $6.9 \mu \mathrm{g} / \mathrm{g}(\mathrm{wb} \mathrm{dw})$ also was measured at this site.

\section{Comparative Analysis of Selenium Concentrations: Fish (Whole-Body and Ovary)}

In general, comparison of mean Se concentrations (wb $\mathrm{dw}$ ) for creek chub and stoneroller from fall (SeptemberOctober 2010) and spring (March-April 2010 and AprilMay 2011) showed an increase in fish wb Se concentration during spring (fig. 20). Fish ovary Se concentrations (dw) for these species trend with wb dw Se concentrations, with the ovary Se concentration being approximately 1.6-fold higher than the wb Se concentration on a site-specific basis (see later discussion in "Conversion Factor: Whole-Body to Ovary" section) (figs. 16-19). The maximum ovary Se concentration measured at stream sites was $22.2 \mu \mathrm{g} / \mathrm{g}$ dw at the Mud River upper site. This site also yielded the highest wb fish Se concentration (figure 20). For comparison, ovary Se concentrations in bluegill sunfish at the Upper Mud River Reservoir in 2006 varied from 21 to $35 \mu \mathrm{g} / \mathrm{g} \mathrm{dw}$, with a mean of $26.2 \mu \mathrm{g} / \mathrm{g} \mathrm{dw}$ (figs. 8 and 11). Ovary Se concentrations measured in three largemouth bass samples from the reservoir site in 2009 were 25, 30, and $65 \mu \mathrm{g} / \mathrm{g} \mathrm{dw}$ (fig. 11).

\section{Comparative Analysis of Selenium Concentrations: Dissolved and Suspended Particulate Material}

Selenium concentrations in suspended particulate material collected by filtration in 2011 showed a range among comparative analysis sites of $0.55-4.2 \mu \mathrm{g} / \mathrm{g} \mathrm{dw}$, with the maximum occurring at Seng Creek (figs. 16-19). Comparison between the February-March and June 2011 samplings at Mud River upper showed 3.2 and $2.3 \mu \mathrm{g} / \mathrm{g}$ dw, respectively. Similarly, seasonal sampling showed (1) 1.6 and $2.2 \mu \mathrm{g} / \mathrm{g} \mathrm{dw}$ for left fork Mud River and (2) 1.8 and $0.72 \mu \mathrm{g} / \mathrm{g}$ dw for Clear Fork upper, during early spring and early summer, respectively.

Several limitations apply to sampling and analysis of suspended particulate material at southern West Virginia study sites. As noted previously, suspended-particulate-material Se concentrations were not available in 2010 because of an analysis error, so only data from the 2011 sampling were available for this application. Only one type of particulate material was collected, with focus on suspended particulate material as an integrator of organic-rich fine-grained biomass. However, the quantity of material available for analysis was small, thereby possibly limiting the representativeness of the aliquot analyzed as it pertains to variability across 
Table 3. Field sites and dates of sampling in 2011 for each type of data used in comparative assessment, modeling, and validation. [Some sites were excluded from analysis because of missing data (NA, not available) - see discussion in text; sampling dates in 2010 are also shown for measurement of physical habitat components, stream attributes, and fish species richness and abundance to support site assessment; dates in table in $\mathrm{m} / \mathrm{d} / \mathrm{yyyy}$ format; wb, whole body; gray shading separates different sampled basins]

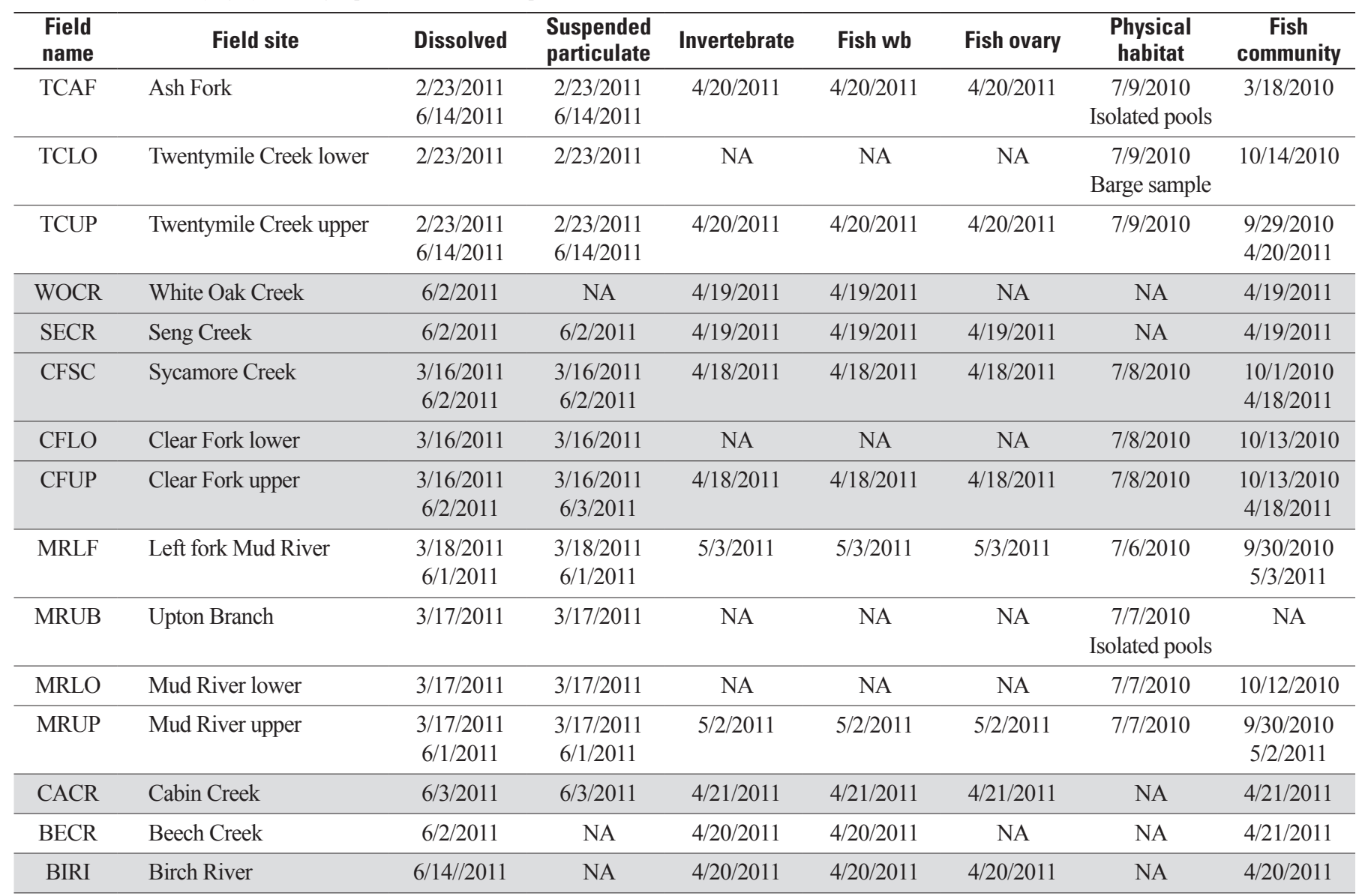

streams. Additionally, the analysis preparation methodology for the suspended-particulate-material phase was not the same for an earlier USGS sampling in 2008 (centrifugation in 2008; filtration in 2011). Bed sediment, considered a less desirable phase for modeling, was also sampled in 2008, yielding a substantially lower Se concentration than that in suspended particulate material. Streams and rivers especially may vary temporally in the number of particulate phases and the contribution of those phases to a suspended-particulatematerial composite. For example, a stream during a relatively high discharge season (that is, February-March) may contain only one particulate phase of limited Se bioavailability, but that stream during a relatively low discharge season (that is, June) may contain a richer set of particulate phases that have had time to reestablish during spring and summer. Several factors may account for this: longer residence times allow for greater uptake of Se in particulate phases, which is accompanied by greater recycling of selenite and organo-Se back into solution, further accelerating uptake (Bowie and others, 1996; Lemly, 2002; Meseck and Cutter, 2006).

As noted previously, the particulate phase and its characterization are important here because (1) the suspendedparticulate-material Se concentration initiates ecosystem-scale Se modeling; and (2) the ratio of the particulate and dissolved media phase Se concentrations at each site quantifies the instantaneous environmental partitioning of Se, and thus, links Se toxicity to water quality as long as intervening steps are adhered to and sufficient data are available (see further discussion in both the "Site-Specific Modeling" and "Model Application" sections).

Time series for dissolved Se concentrations at sites where sampling occurred more than once during 2010 and 2011 are shown in figure 21A. One-time dissolved Se concentration measurements also are shown (fig. 21A). Time series for general water-quality parameters (temperature, conductivity, and sulfate concentration) are shown for context (figs. 21B-D). Elevated conductivity and sulfate values both have been connected to mining activity in southern West Virginia (Palmer and others, 2010; Bernhardt and others, 2012). The peaks in the patterns for dissolved Se at Mud River upper and lower are noticeably offset from the patterns for conductivity and sulfate concentration. At sites with lesser Se concentrations, the offset is not as pronounced. However, peaks in Se concentration coincided with peaks in temperature during August 2010 and June 2011 (see further discussion in "Temporal Exposure" section). 


\section{Mud River USGS Sites}
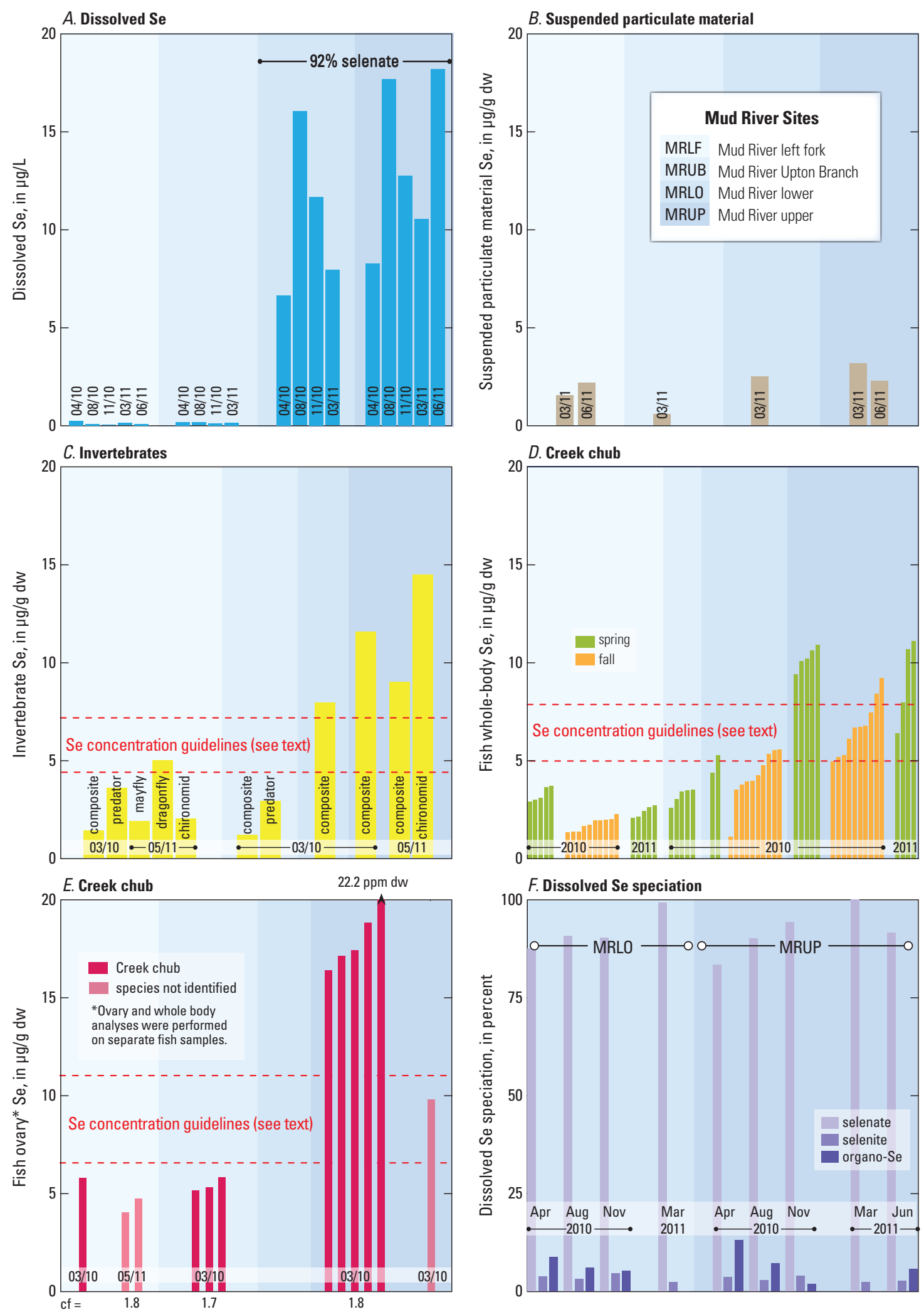

Individual Analysis

Figure 16. Bar graphs showing assessed Se concentrations within the progression of $(A)$ dissolved, $(B)$ suspended particulate material, (C) invertebrate, and ( $D$ and $E$ ) fish for USGS sites sampled in the Upper Mud River basin in 2010 and 2011. Dissolved Se speciation is also shown (F). cf = conversion factor (whole-body to ovary). 
Clear Fork Basin USGS Sites (2010-2011)
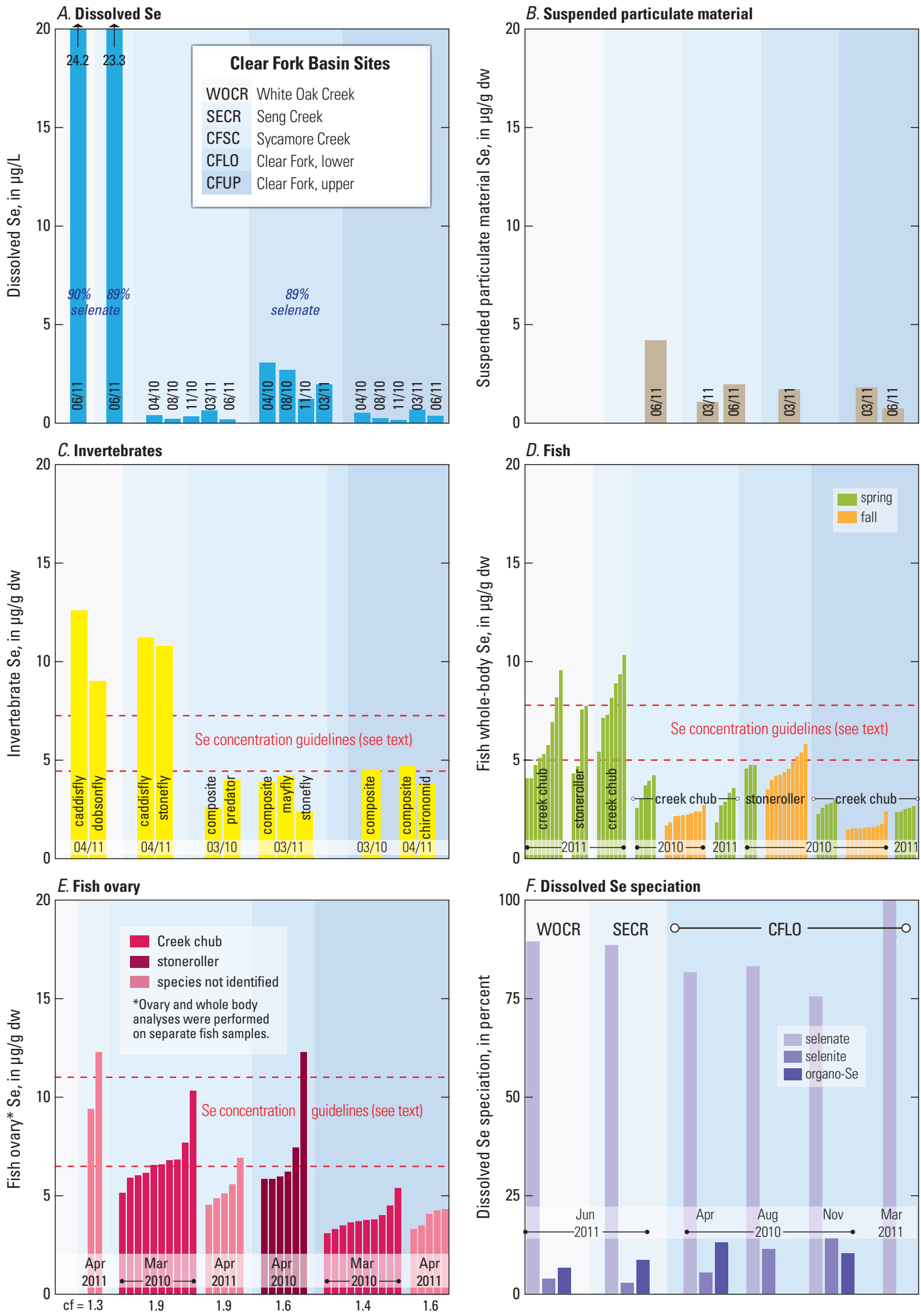

Figure 17. Bar graphs showing assessed $\mathrm{Se}$ concentrations within the progression of (A) dissolved,

$(B)$ suspended particulate material, (C) invertebrate, and ( $D$ and $E$ ) fish for USGS sites sampled in the Clear Fork basin in 2010 and 2011. Dissolved Se speciation is also shown (F). cf = conversion factor (whole-body to ovary).

Individual Analysis 
Twentymile Creek Basin USGS Sites (2010-2011)
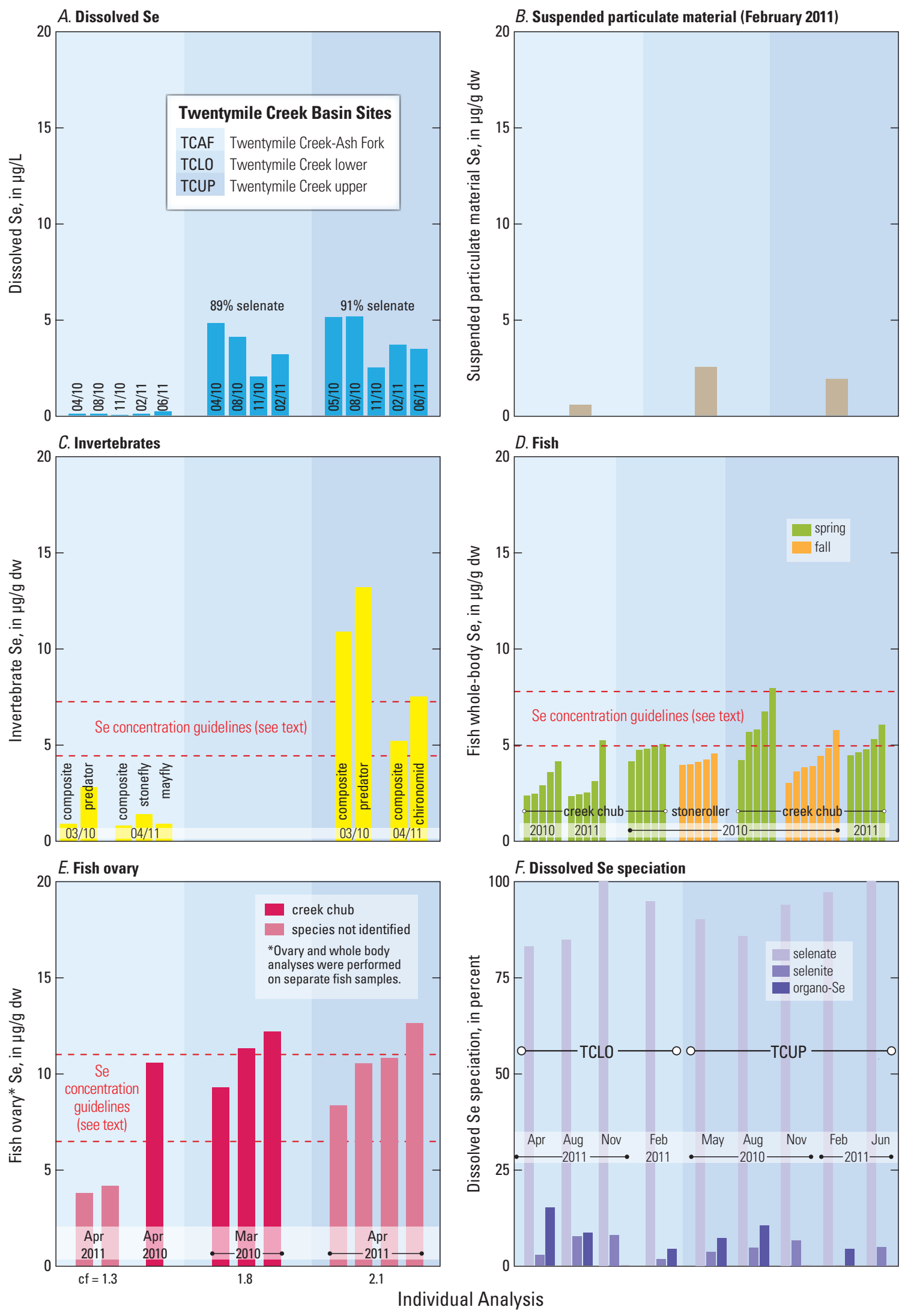

Figure 18. Bar graphs showing assessed $\mathrm{Se}$ concentrations within the progression of (A) dissolved, (B) suspended particulate material, $(C)$ invertebrate, and ( $D$ and $E$ ) fish for USGS sites sampled in the Twentymile Creek basin in 2010 and 2011. Dissolved Se speciation is also shown (F). cf = conversion factor (whole-body to ovary). 
Cabin Creek, Beech Creek, and Birch River USGS Sites, in 2011
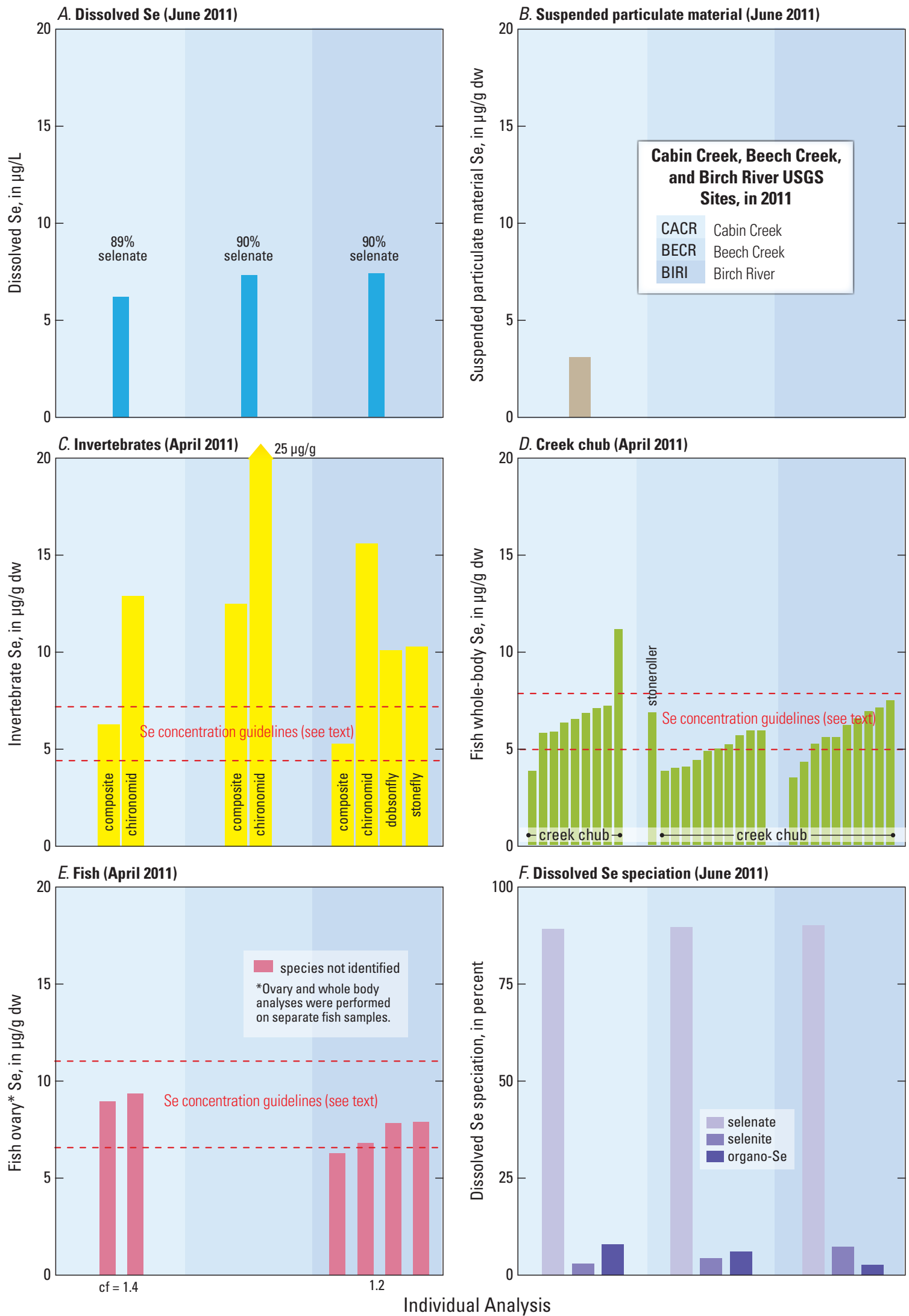

Figure 19. Bar graphs showing assessed Se concentrations within the progression of (A) dissolved, $(B)$ suspended particulate material, (C) invertebrate, and ( $D$ and $E$ ) fish for USGS sites for Cabin Creek, Beech Creek, and the Birch River in 2011. Dissolved Se speciation is also shown (F). cf = conversion factor (whole-body to ovary). 
The sites at Mud River upper and lower consistently exceeded the current $5 \mu \mathrm{g} / \mathrm{L}$ water-quality criterion for the protection of aquatic life (USEPA, 1987) (fig. 21A). The range of dissolved Se concentrations for Mud River upper and lower sites was $6.6-18.2 \mu \mathrm{g} / \mathrm{L}$. The dissolved Se concentration for Twentymile Creek upper was $5.1 \mu \mathrm{g} / \mathrm{L}$ in April and August 2010, but ranged between 2.5 and $3.6 \mu \mathrm{g} / \mathrm{L}$ during sampling in November 2010, March 2011, and June 2011 (fig. 21A). Dissolved Se concentrations for Twentymile Creek lower and Clear Fork lower ranged between 1.2 and $4.8 \mu \mathrm{g} / \mathrm{L}$ during sampling in 2010 and 2011 (fig. 21A). Ash Fork, Sycamore Creek, Clear Fork upper, left fork Mud River, and Upton Branch were all $<1 \mu \mathrm{g} / \mathrm{L}$ (fig. 21A). Selenium concentrations at sites sampled only once in June 2011 (White Oak Creek, Seng Creek, Cabin Creek, Beech Creek, and the Birch River) (fig. 21A) all exceeded $5 \mu \mathrm{g} / \mathrm{L}$. Selenium concentrations were highest at White Oak Creek $(24 \mu \mathrm{g} / \mathrm{L})$ and Seng Creek $(23 \mu \mathrm{g} / \mathrm{L})$.

The most abundant dissolved Se species was selenate at all sites in 2010 and 2011(figs. 16-19). For sites where comparisons could be made, the months of April and August showed peak percentages of organo-Se (maximum, 13 percent). For example, at the Mud River upper site, 100 percent selenate was measured in March 2011, in contrast to 83 percent in April 2010 (see further discussion of Se speciation in "Links to Dissolved Se Concentrations" section). Data for Se speciation for sites where Se concentrations were $<1 \mu \mathrm{g} / \mathrm{L}$ were not reported here because of the greater uncertainty of values determined near the detection limit for Se.

\section{Site-Specific Modeling}

\section{Conceptual Models and Exposure Scenarios}

A Se pathway and the hydrologic settings (stream, reservoir, pond, and outfall) of a generalized schematic of the mountaintop coal mining process and valley fill landscape provide a framework for modeling (fig. 5), while food-web conceptual models depict ecosystem specifics (fig. 22).

Development of comprehensive food-web conceptual models and exposure scenarios are initial steps in modeling, in that it is the choice of fish species that sets the choice of dietary prey (that is, what species of prey does the fish consume?) (Presser and Luoma, 2010a). Specifics of these food-web conceptual models were chosen in collaboration with the WVDEP.

Conceptual ecosystem-scale Se modeling as derived for the assessed basins shows predator and prey species within stream, reservoir, or pond settings and the type of model parameters $\left(K_{\mathrm{d}}, \mathrm{TTF}_{\text {invertebrate }}\right.$, and $\left.\mathrm{TTF}_{\text {fish }}\right)$ that link them (fig. 22). A conceptual model for valley-fill ponds also was included based on earlier data showing (1) dissolved Se concentrations in ponds elevated over those of sampled streams (fig. 2); and (2) fish Se concentrations of up to 113 $\mu \mathrm{g} / \mathrm{g}(\mathrm{wb} \mathrm{dw})$ in a pond associated with the Jacks Branch Mine drainage (fig. 10B). However, waters of valley-fill ponds are not considered "waters of the state" and are thus exempt from regulation (West Virginia Legislature, 2012).

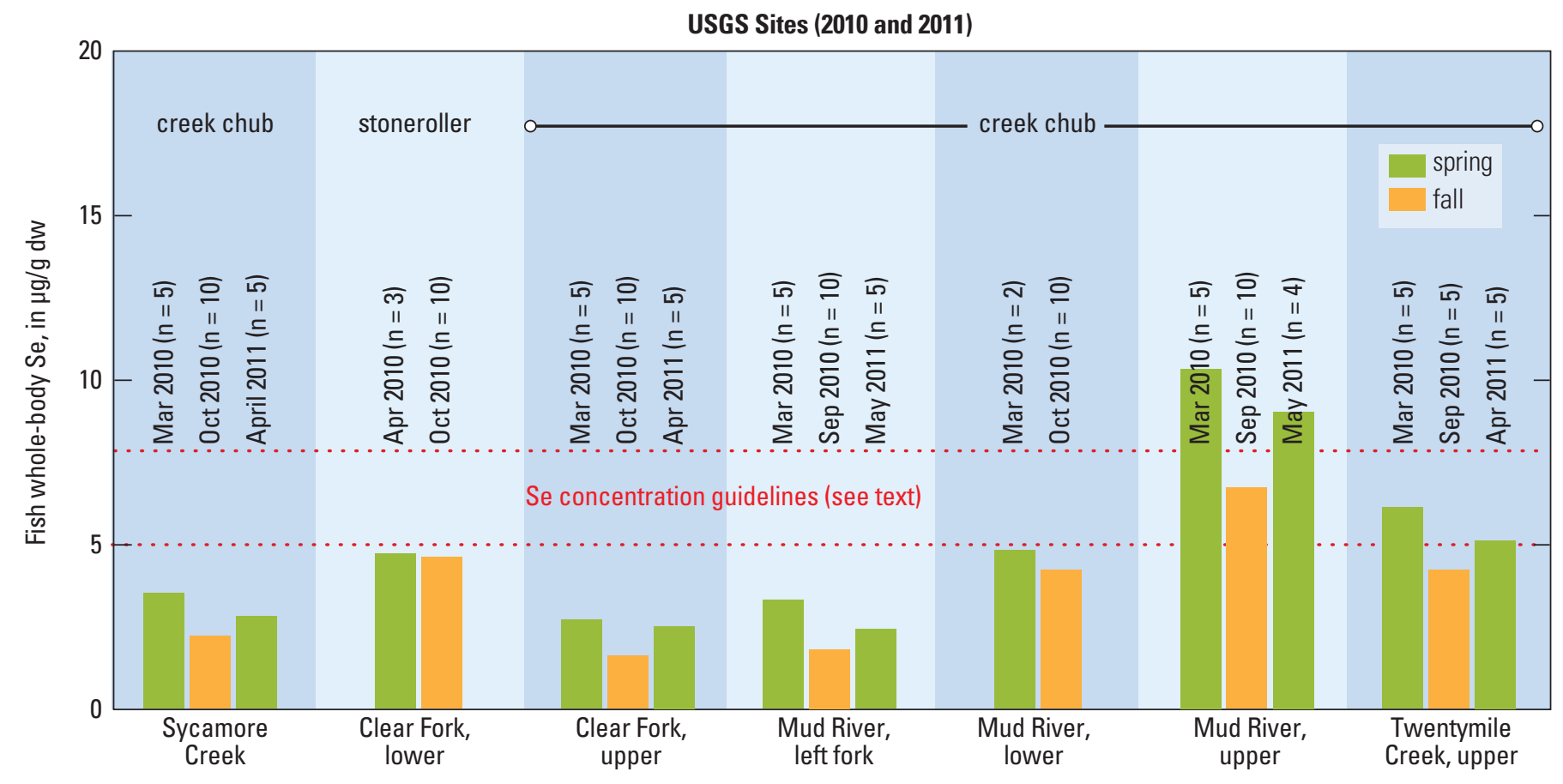

Figure 20. Bar graphs showing comparison of Se concentrations in fish for USGS sites sampled during fall 2010, spring 2010, and spring 2011. 
Food-web modeling specific to hydrologic setting (fig. 22) includes:

- stream

- particulate to aquatic insect to creek chub, green sunfish, or bluegill sunfish

- particulate to aquatic insect to young creek chub to adult rock bass or adult omnivorous fish species

- particulate to clam to white sucker

- particulate to chironomid to rainbow darter

- particulate directly to stoneroller

- particulate directly to young stoneroller to adult rock bass or omnivorous fish species

- reservoir

- particulate to aquatic insect to bluegill sunfish, green sunfish, or crappie

- particulate to aquatic insect to young bluegill sunfish to adult largemouth bass or adult omnivorous fish species

- particulate to snail to redear sunfish or pumpkinseed sunfish

- particulate to clam to channel catfish or common carp

- particulate to crayfish directly to TL3 or 4 adult fish species

- valley fill pond (hypothetical)

- particulate to aquatic insect to creek chub, green sunfish, or bluegill sunfish

- particulate to aquatic insect to young creek chub to adult omnivorous fish species

- particulate to clam to green sunfish

- particulate to chironomid to bluntnose minnow

In general, these conceptual food webs are a balance between strict site-specific species scenarios and species scenarios that illustrate the fundamental mathematics of Se exposure as derived from species-specific Se biodynamics (that is, invertebrate TTFs are primary to fish vulnerability). In some instances, choices also can represent mathematical end-members to show the limits of ecological sensitivity to model parameters. In the scenarios illustrated here, aquatic invertebrates and such species as creek chub, green sunfish, and bluegill sunfish form key site-specific food webs, as does the herbivorous stoneroller (fig. 22). Similarly, modeling of clam to channel catfish or common carp is ecologically realistic for a reservoir. In contrast, the redear sunfish scenario was derived to exemplify a food web that has the highest TTFs of invertebrates considered here (that is, $\mathrm{TTF}_{\text {snail }}=5.5$ ) and hence serves as an end-member for exposure. However, the native redear sunfish is now rarely present in West Virginia (Stauffer and others, 1995). Additionally, the scenarios illustrating forage fish [Trophic Level 3 (TL3) fish] to predator fish (TL4 fish) are very ecologically explicit, yet these foodweb scenarios have a common mathematical additional trophic transfer step $\left(\mathrm{TTF}_{\text {forage fish }}=1.1\right)$. In this regard, although not illustrated here, consumption of darter and minnow by adult fish also could be modeled using this common step. Young creek chub or bluegill sunfish to adult bass or omnivorous fish species food webs also can represent consumption by other predatory fish species (for example, muskellunge in the Upper Mud River Reservoir). As noted previously, the model could be strengthened with additional quantitative specificity (for example, use of equation 10 to consider a mixed diet).

In optimal modeling, scenarios and outputs would be within a specified discharge season, water residence time, or load regime that may be dependent on Se source dynamics to add a temporal component to the hydrologic setting and food-web choices (Presser and Luoma, 2010b, 2013). The development of predator (1) dietary prey fractions (for example, Tarter, 1970 for dace; http://www.fishesoftexas. org/taxonomy, in general); (2) life cycle diagrams; and (3) habitat-use models would improve the specificity of modeling by illustrating the timing and connection to critical life stages and food availability) (Presser and Luoma, 2010b, 2013). Besides Se-exposure specificity and a temporal aspect, using traditional comparative fish traits (for example, table 1; tolerance; or habitat preference) (http://www.lib.vt.edu/find/ databases/F/fishtraits-database.html; Short and others, 2008) could inform initial site selections and augment food-web interconnections at a level of reasoning different from the mathematics of Se biodynamics.

These conceptual food webs serve both model validation and model application, as detailed below. Field assessment data here were limited in terms of species, and hence modeling predictions are limited. However, for an application of the model given later (see "Model Application" section), the exposure scenarios illustrated in figure 22 for additional food-web steps and species indicative of southern West Virginia basins affected by mountaintop coal mining and valley fills are explicitly used for prediction.

\section{Primary Food Webs and Prediction}

Site-specific modeling here predicts how Se moves through stream, reservoir, or pond ecosystems of southern West Virginia (tables 4 and 5). The model scenarios generate prey and predator Se concentrations from field observations of Se concentrations in suspended particulate material (Presser and Luoma, 2010a). Thus, this approach tests whether bioaccumulation at the invertebrate and predator trophic levels can be predicted accurately if particulate Se concentrations are known. As noted previously, figure 6 shows a schematic of the methodology, quantifying factors, and model equations for the ecosystem-scale modeling approach.

Modeling was performed for stream exposure scenarios within the Twentymile Creek, Clear Fork, and Upper Mud River basins and for the Cabin Creek site. As mentioned previously, modeling and prediction could not be performed for White Oak Creek, Beech Creek, and the Birch River 
A. Dissolved Se time series

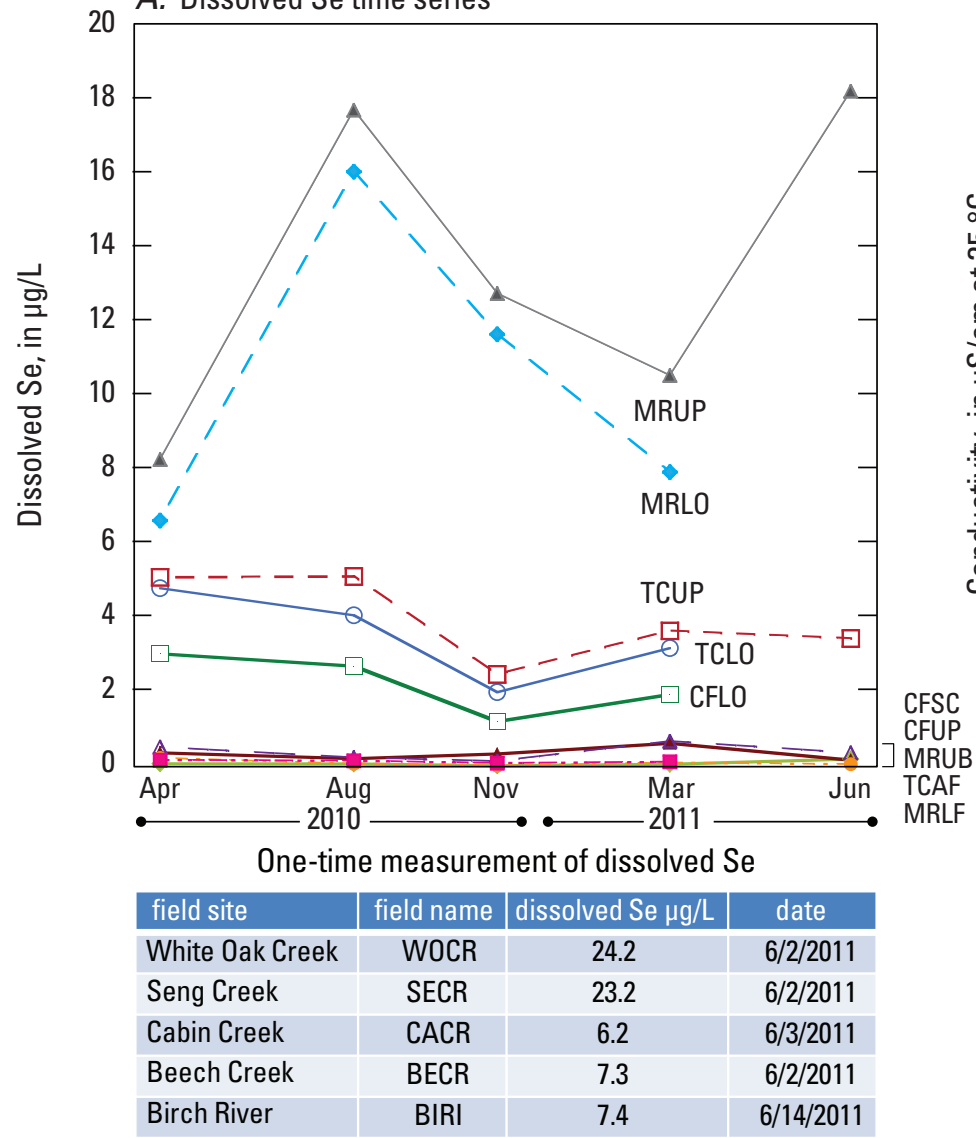

C. Sulfate time series

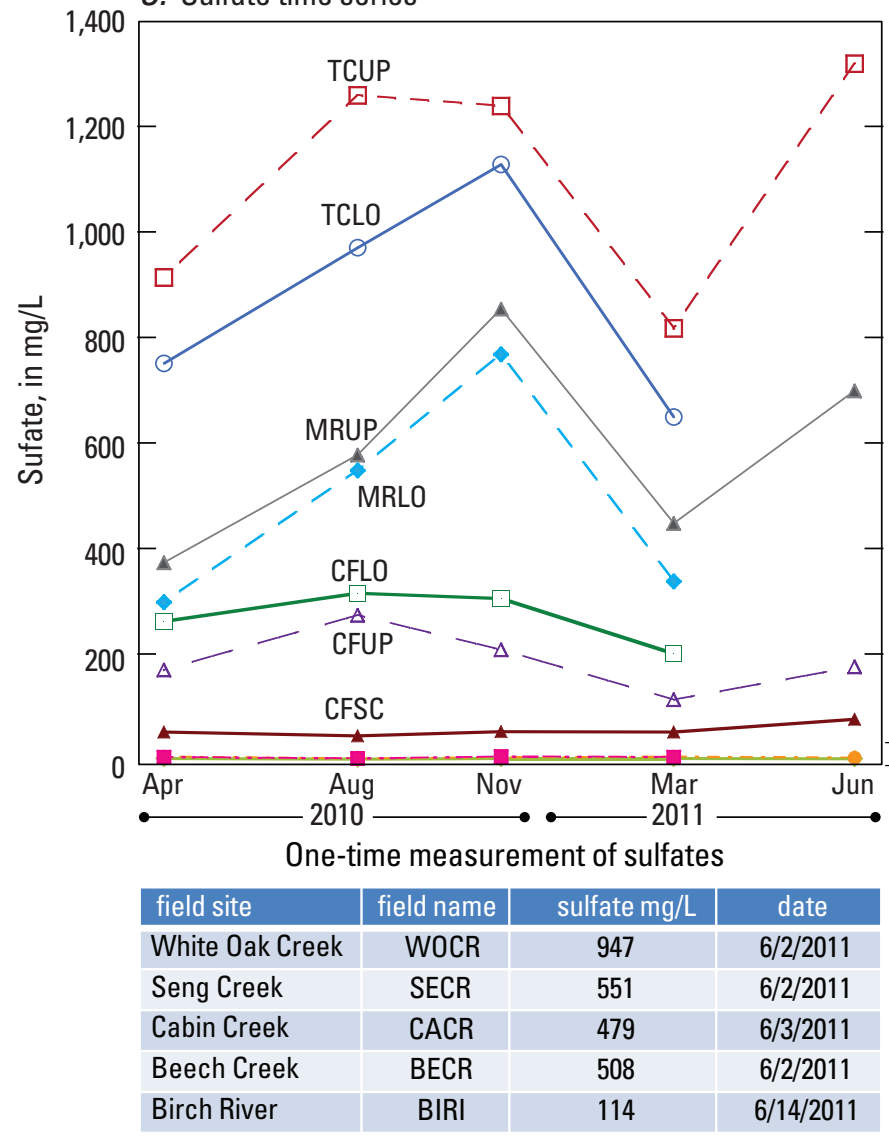

$B$. Conductivity time series

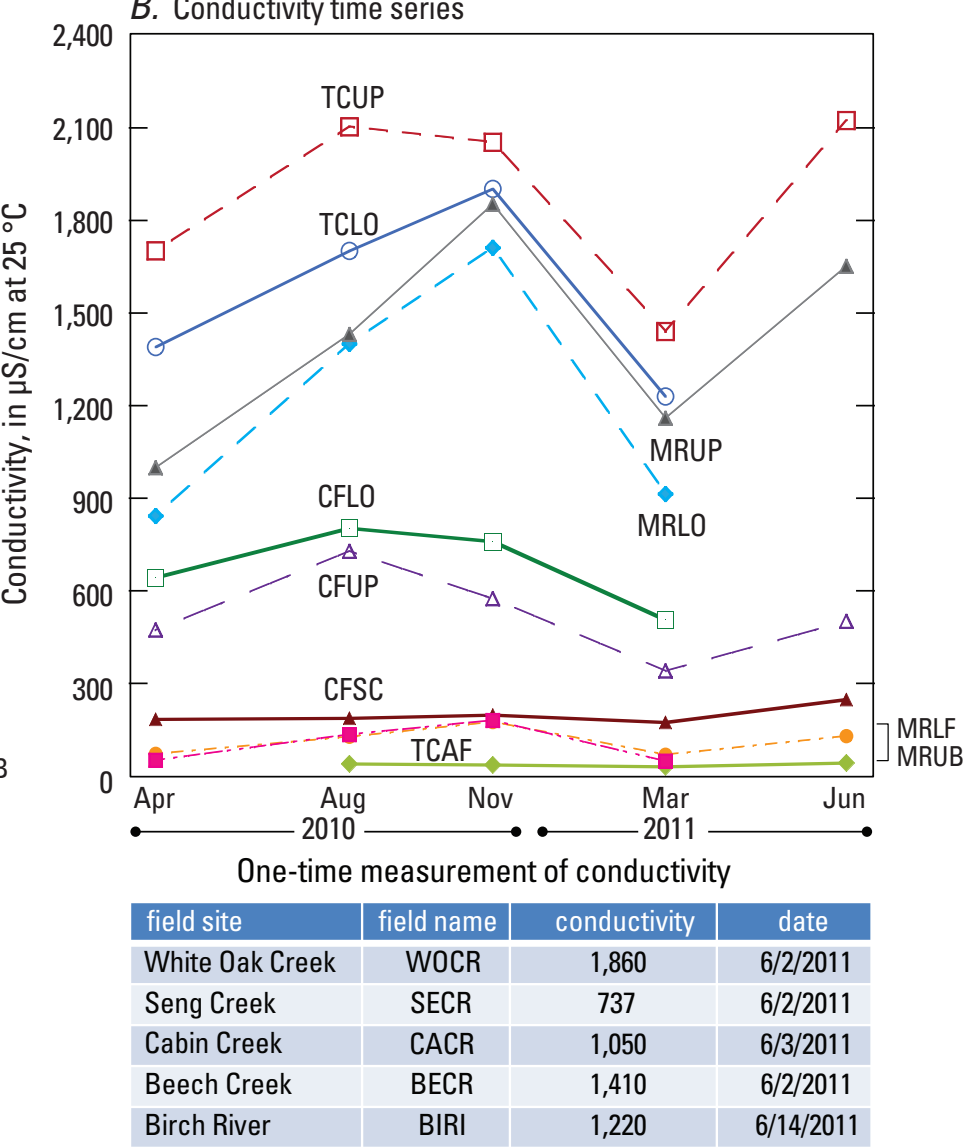

$D$. Water temperature time series

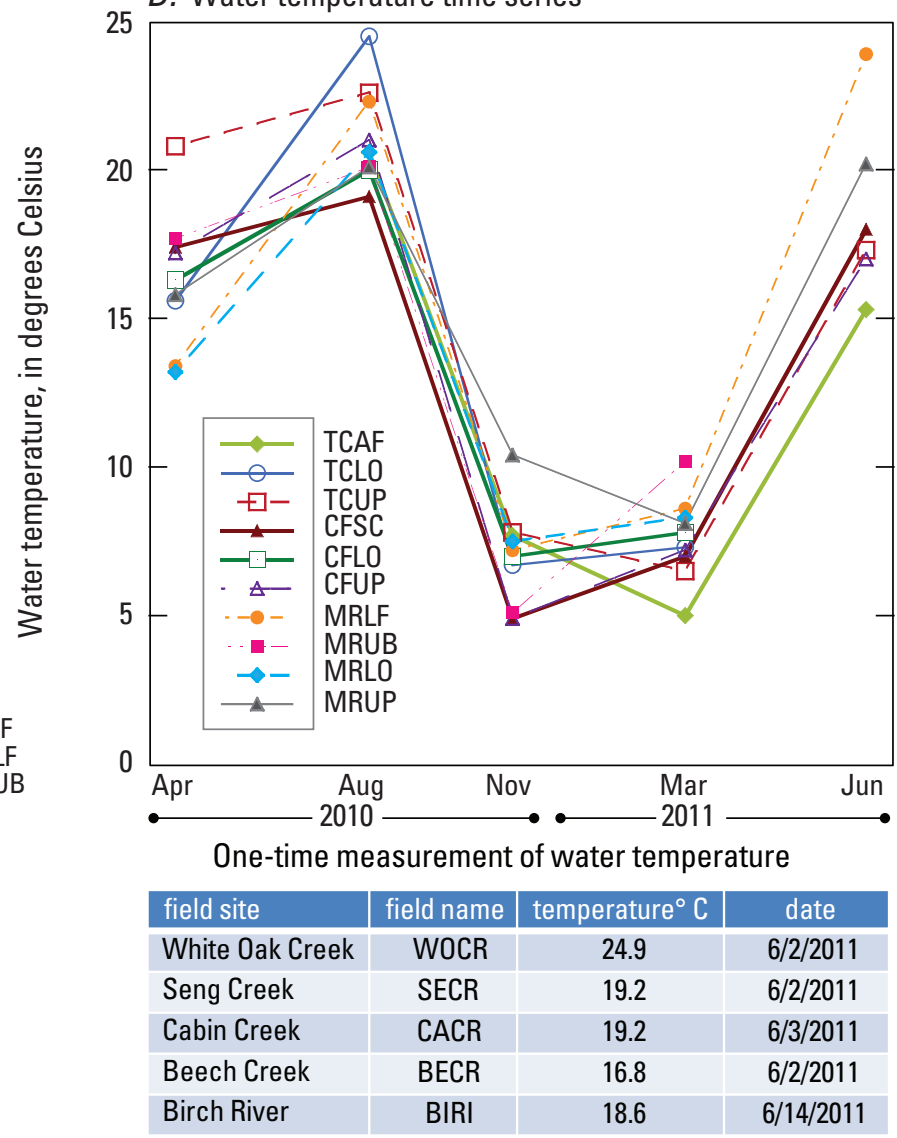


because of a lack of data for a suspended-particulate-material Se concentration to initiate modeling. Details of food-web field data, including dissolved and suspended-particulatematerial Se concentrations, and modeling calculations, for each site are shown in tables 4 and 5. These sites showed observed dissolved Se concentration range of $<0.14$ to 23 $\mu \mathrm{g} / \mathrm{L}$, a range that encompasses sites both above and below the current $5-\mu \mathrm{g} / \mathrm{L}$ Se criterion. Food-web datasets from 2005-2009 also were modeled for the Upper Mud River system, including the Mud River (upper or at mile 75.6 data) and Upper Mud River Reservoir. Plum Orchard Lake Se concentrations are listed for reference. These earlier datasets were not temporally matched, but are used here to generally compare stream conditions within the basin over time (for example, 2008 versus 2011) and to compare Se transfer among stream and impoundment ecosystems.

The primary food web illustrated was suspended particulate material to aquatic insect to creek chub (tables 4 and 5; fig. 22). Table 1 shows a preponderance of insectivores among southern West Virginia fish species. The diet for fish was assumed to be 100 percent aquatic insect in each exposure scenario. Many variations in diet are possible, but for initial runs of the model a singlecomponent diet was assumed. The range of aquatic insects sampled in the field at these sites was limited to mayfly, caddisfly, stonefly, dobsonfly, and chironomid. Singletaxon or composite invertebrate samples were available for comparison of observed invertebrate concentrations to predicted invertebrate concentrations. From the literature, aquatic insects such as these (mayfly, caddisfly, cranefly, stonefly, damselfly, corixid, and chironomid) were found to have similar TTFs, within a range of 2.3-3.2 (Presser and Luoma, 2010a; Conley and others, 2009). Thus, because of the apparent limited food web and its characterization here, a $\mathrm{TTF}_{\text {aquatic insect }}$ of 2.8 was assumed. To test the sensitivity of the model to a predator and its choice of food, Se concentrations in stoneroller were predicted based on a food web of suspended particulate material directly to stoneroller, without an invertebrate transfer step (tables 4 and 5; fig. 22).

Food webs for the right fork of the Upper Mud River Reservoir were modeled as more complex, with clam (Corbicula), snail (Planorbidae), crayfish, and dragonfly present (tables 4 and 5). Invertebrate TTFs used for the reservoir modeling were: $\mathrm{TTF}_{\text {dragonfly }}=2.8$ ( similar to damselfly at 2.6); $\mathrm{TTF}_{\text {crayfish }}=1.6$; and $\mathrm{TTF}_{\text {clam }}=4.0$ (Corbicula fluminea; Presser and Luoma, 2010a). Damselfly and dragonfly could be considered predatory insects, warranting a higher trophic level of modeling, but this detail of modeling was not considered

Figure 21. Time-series graphs of $(A)$ dissolved Se

concentrations, $(B)$ conductivity, $(C)$ sulfate concentrations, and (D) temperature for USGS sites sampled during 2010 and 2011. MRLO, Mud River lower; MRUP, Mud River upper; MRLF, left fork Mud River; MRUB, Upton Branch; CFSC, Sycamore Creek; CFLO, Clear Fork lower; CFUP, Clear Fork upper; TCLO, Twentymile Creek lower; TCUP, Twentymile Creek upper; TCAF, Ash Fork. here. A site-specific $\mathrm{TTF}_{\text {snail }}$ of 5.5 was used to illustrate a known component of the reservoir food web, but for which no literature TTF was available. This value is similar to a site-specific $\mathrm{TTF}_{\text {snail }}$ of 5.0 calculated for the left fork of the Upper Mud River Reservoir (fig. 11). Samples collected at both sites were planorbid snails.

Creek chub was sampled at all sites, while central stoneroller was sampled at Twentymile Creek lower, Clear Fork lower, Beech Creek, and White Oak Creek. A TTF ${ }_{\text {fish }}$ of 1.1 was assumed, which is the mean value among fish species studied (Presser and Luoma, 2010a). A variety of fish species (bluegill sunfish, green sunfish, and largemouth bass) were present in the reservoir. Here again, a $\mathrm{TTF}_{\text {fish }}$ of 1.1 was used. For the reservoir, food webs are not specifically matched between invertebrate and fish species because not enough detail was available for species-specific diets, and fish and invertebrate samples were not temporally matched.

\section{Model Outcomes and Validation}

Modeled and observed Se concentrations in invertebrates and fish are shown in tables 4 and 5. The predicted Se concentrations were compared to observed concentrations for spatially matched datasets for invertebrates (mean, composite, or individual taxon) and fish (wb) to validate or estimate uncertainties in modeling. Ovary Se concentrations also are shown because of the relevance of reproductive tissue in confirming Se risk. Validation is necessary to establish sufficient confidence that the predictions from the developed model can be usefully applied to ecosystems in southern West Virginia.

The first correlation compared observed Se concentrations in aquatic insects ( $\mathrm{dw}$ ) with concentrations predicted from observed particulate concentrations (dw) and

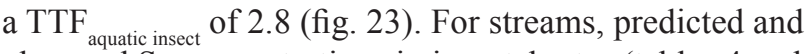
observed Se concentrations in invertebrates (tables 4 and 5) showed a high degree of correlation, with a calculated coefficient of determination $\left(r^{2}\right)$ of 0.906 (fig. 23A). The range of predicted invertebrate Se concentrations was $1.5-10.9 \mu \mathrm{g} / \mathrm{g} \mathrm{dw}$, and the range of observed invertebrate Se concentrations was $0.8-11 \mu \mathrm{g} / \mathrm{g} \mathrm{dw}$. If data are included for invertebrates (excluding predictions for snail because of an absence of a $\mathrm{TTF}_{\text {snail }}$ ) from the right fork of the Upper Mud River Reservoir (that is, to include the upper end of the range of invertebrate Se concentrations), then the coefficient of determination $\left(\mathrm{r}^{2}\right)$ was 0.967 (fig. 23B). For the reservoir, the range of predicted invertebrate Se concentrations was 10.7 to $26.8 \mu \mathrm{g} / \mathrm{g} \mathrm{dw}$ and the range of observed invertebrate Se concentrations was 10.2 to $30.6 \mu \mathrm{g} / \mathrm{g} \mathrm{dw}$. For comparison, measured Se concentrations (mean, range, or single taxon analysis, dw) for invertebrates at the reservoir site were: crayfish, 10.2, 7.8-13 $\mu \mathrm{g} / \mathrm{g}$; clam, 30.6, 23-29 $\mu \mathrm{g} / \mathrm{g}$; snail, $36.6 \mu \mathrm{g} / \mathrm{g}$; and dragonfly, $16.5 \mu \mathrm{g} / \mathrm{g}$. For the invertebrate with the highest TTF, the modeled potential for 
Conceptual Models for Mountaintop Mining and Valley-Fill Aquatic Ecosystems

—within a specified flow season, residence time, or load regime
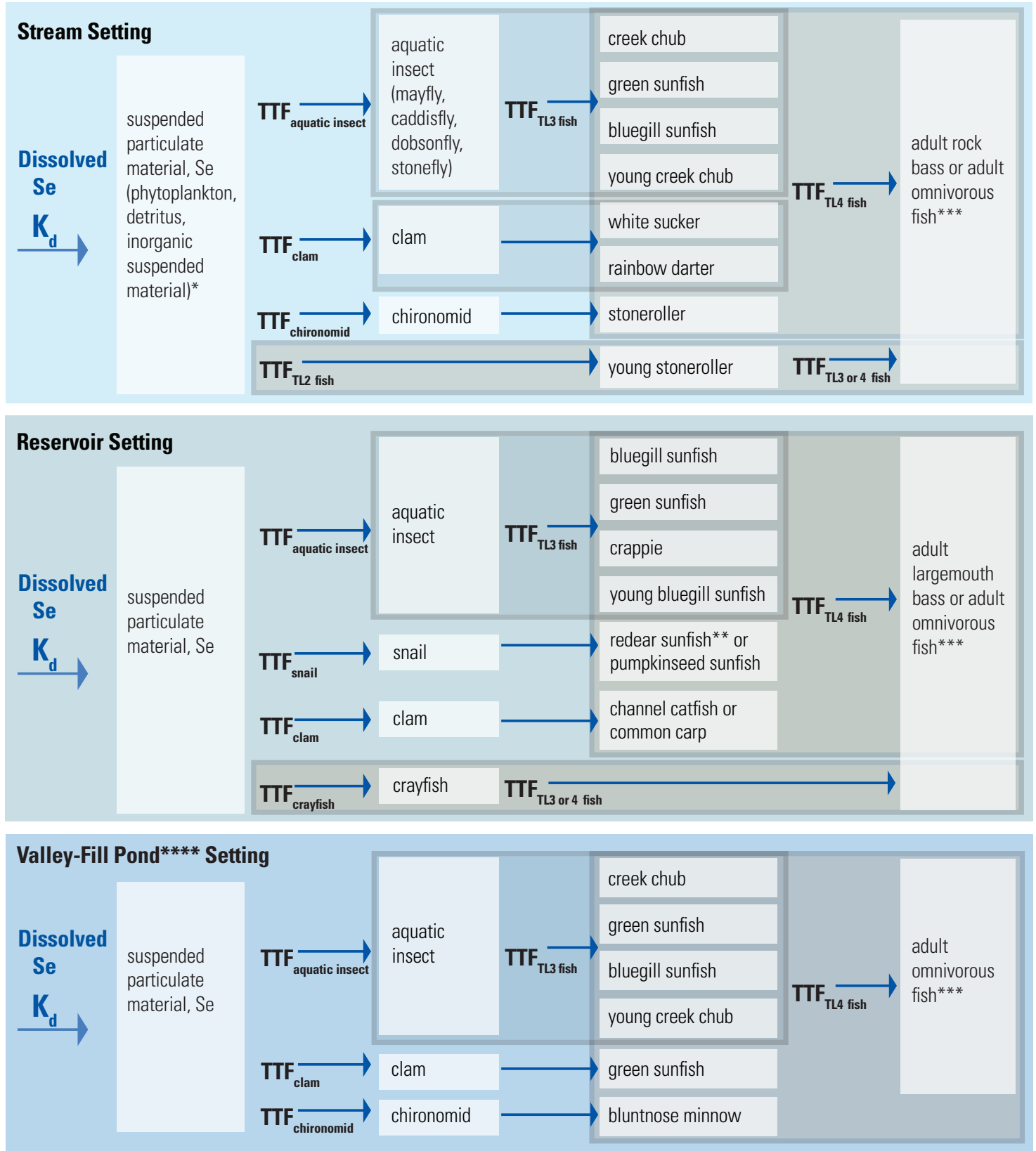

*Sampling of particulate material at the base of a food web can also include periphyton, biofilm, sediment, or attached vascular plants.

**The redear sunfish and pumpkinseed sunfish are used here as examples of molluscivores (that is, primary percentage of snail or clam diet endmember). The redear sunfish is reported as native to West Virginia, but is now rarely present in the state.

***Species of omnivorous fish include blacknose dace, common carp, channel catfish, white sucker, and crappie. Muskellunge are present in the Upper Mud River Reservoir. Creek chub also can be a generalist, but here is modeled as an insectivore.

****Valley-fill ponds are not considered "waters of the state" (that is, exempt from regulation) (West Virginia Legislature, 2012).

Figure 22. A conceptual ecosystem-scale Se model as applied to the mountaintop mining and valley-fill regions of southern West Virginia. Examples of predator and prey species within a stream or reservoir setting and the model parameters that link them are shown. In modeling, outputs would be within a specified hydrologic setting with reference to a flow season, residence time, or load regime. $K_{d^{\prime}}$ partitioning factor; TTF, trophic transfer factor; $\mathrm{TL}=$ trophic level. 
Table 4. Modeling and validation showing observed and predicted Se concentrations for invertebrates.

[Trophic transfer factors: $* \mathrm{TTF}_{\text {aquatic insect }}=2.8 ; * * \mathrm{TTF}_{\text {crayfish }}=1.6 ; * * * \mathrm{TTF}_{\text {clam }}=4.0 ;$ upper range (Presser and Luoma, 2010a); $* * * * \mathrm{TTF}_{\text {snail }}=5.5$ (field); $\mathrm{NA}=$ not available; $\mu \mathrm{g} / \mathrm{g} \mathrm{dw}$, micrograms per gram dry weight; italicized text $=<$ method quantitation limit; predicted values in blue]

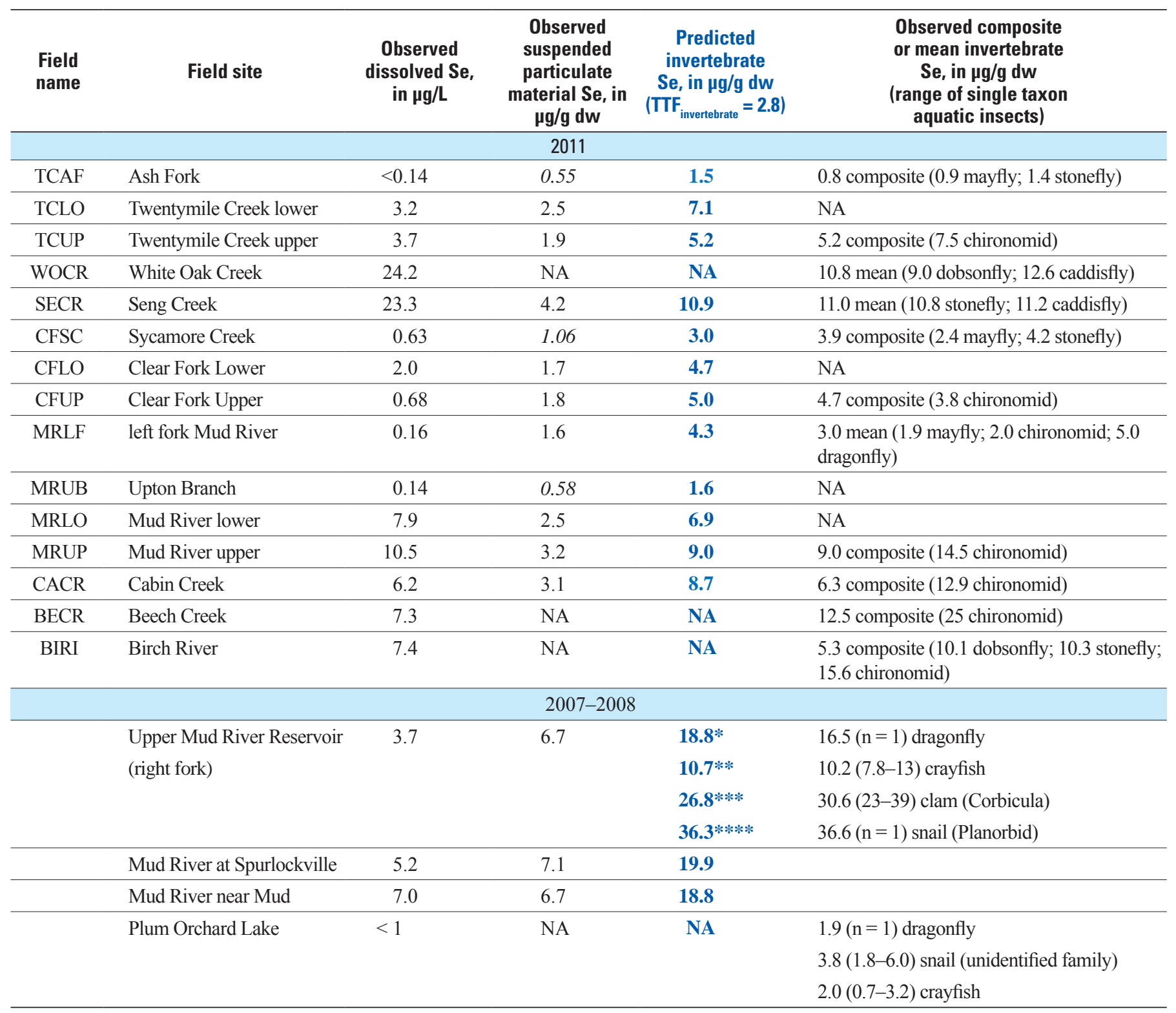

bioaccumulation reached $26.8 \mu \mathrm{g} / \mathrm{g} \mathrm{dw}$, whereas the observed maximum was $30.6 \mu \mathrm{g} / \mathrm{g}$ dw in clams (tables 4 and 5).

The second correlation compared observed Se concentrations in creek chub and stoneroller ( $w b \mathrm{dw}$ ) with concentrations predicted from observed particulate concentrations, a TTF aquatic insect $_{\text {of }} 2.8$ (that is, the previously predicted invertebrate Se concentrations), and the universal

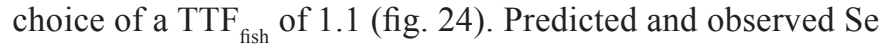
concentrations in fish (table 5) showed a strong correlation, with a calculated coefficient of determination $\left(r^{2}\right)$ of 0.754 (fig. 24). The range of predicted fish Se concentrations (wb dw) in stream sites was 1.7 to $12 \mu \mathrm{g} / \mathrm{g}$ and the range of observed fish Se concentrations was 2.4 to $9.0 \mu \mathrm{g} / \mathrm{g}$.
In a separate test of modeling sensitivity, modeling of the food-web exposure scenario for particulate material directly to stoneroller in streams showed lower predicted Se concentrations in fish (range 0.6-4.6 $\mu \mathrm{g} / \mathrm{g}$ wb dw) (table 5) mainly because of a lack of an invertebrate transfer step. These predicted Se concentrations for stoneroller represent, in most cases, the lower end of the range of measured Se concentrations. The Upper Mud River Reservoir mean data points were not used in the second correlation because of their determinative effect on the curve fit (that is, one upper range point dominated the correlation). However, if the average observed fish concentration for the reservoir is used, then the correlation improves $\left(r^{2}=0.944\right)$. 
Table 5. Modeling and validation showing observed and predicted Se concentrations for fish.

[Trophic transfer factor: $* \mathrm{TTF}_{\text {aquatic insect }} 2.8 ; * * \mathrm{TTF}_{\text {crayfish }} 1.6 ; * * * \mathrm{TTF}_{\text {clam }} 4.0$; upper range (Presser and Luoma, 2010a); ****TTF snail 5.5 (field); $* * * * * 2010$ ovarySe dataset, 18.4 (16.4-22.2 $\mu \mathrm{g} / \mathrm{g} \mathrm{dw}) ; \mu \mathrm{g} / \mathrm{g} \mathrm{dw}$, micrograms per gram dry weight; ; wb, whole body; NA = not available; predicted values in blue]

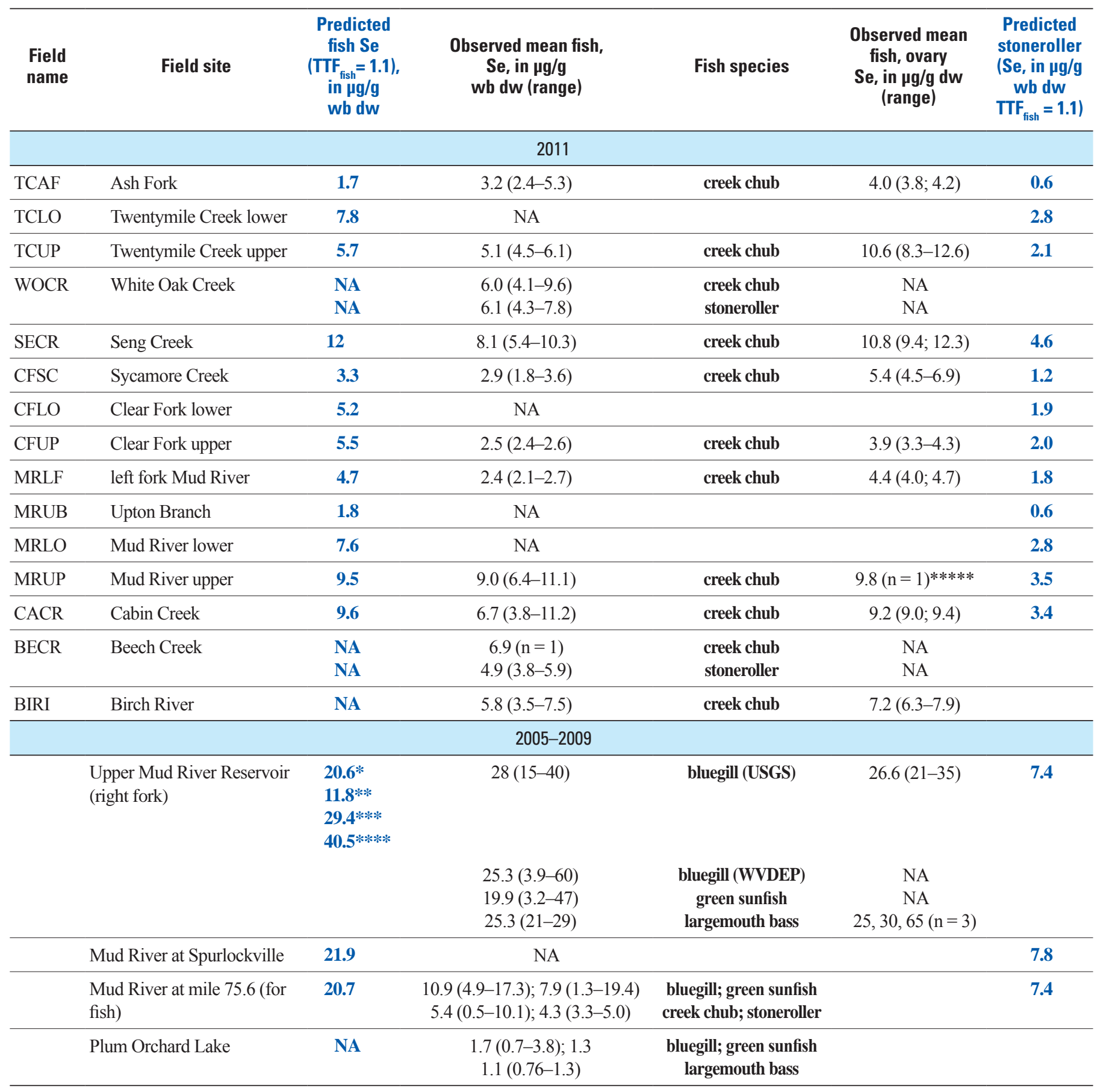



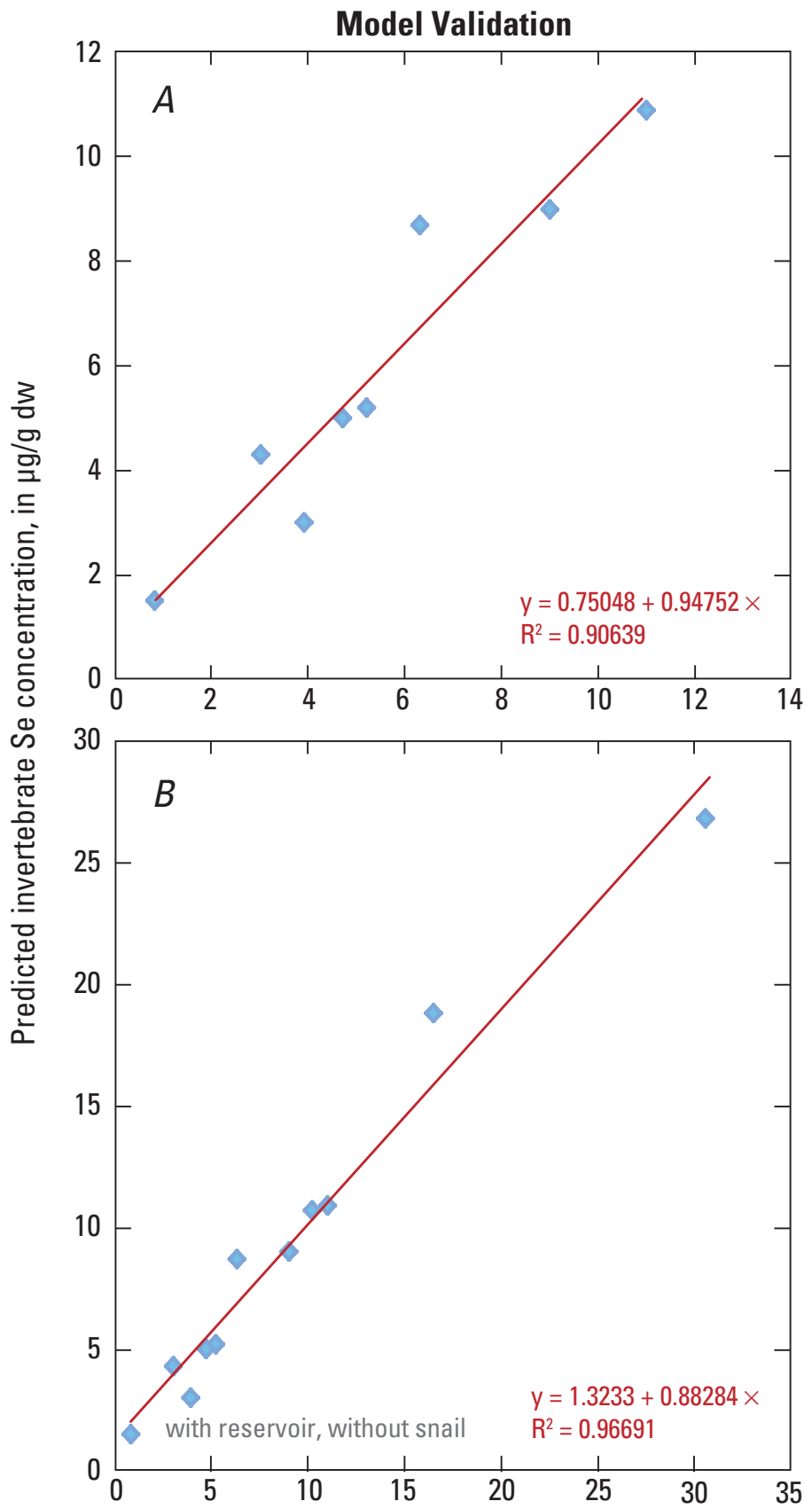

Observed invertebrate Se concentration, in $\mu \mathrm{g} / \mathrm{g} \mathrm{dw}$

Figure 23. Graphs showing linear regression and correlation of observed Se concentrations in aquatic insects and those concentrations predicted through ecosystem-scale modeling from observed particulate concentrations. $A$, USGS sites. $B$, With data from Upper Mud River Reservoir site added in.
The strong regressions derived here from modeling show that if particulate Se concentrations are known and food webs are considered in an ecologically based way, Se bioaccumulation can be reliably predicted in the different food webs of ecosystems influenced by coal mining and valley fill. Site-by-site consideration of the assessment data (figs. 11-15), food-web compilations (figs. 16-19), and modeling (tables 4 and 5) is given below to demonstrate that the model is able to generate the Se concentrations seen in the sampled basins and accurately predict Se concentrations in invertebrates and fish, components critical to ecosystem protection for Se.

Sites at Ash Fork, Sycamore Creek, Clear Fork upper, left fork Mud River, and Upton Branch (food webs, figs. 16-19; data figs. 11-15; modeling tables 4 and 5) showed the lowest observed environmental Se concentrations (that is, mean fish Se concentrations of $<3.2 \mu \mathrm{g} / \mathrm{g} w b \mathrm{dw}$ ). Predicted Se concentrations for aquatic insects were $<5 \mu \mathrm{g} / \mathrm{g} \mathrm{dw}$ and those for fish were $<5.5 \mu \mathrm{g} / \mathrm{g}$ ( $w b \mathrm{dw}$ ) for these sites.

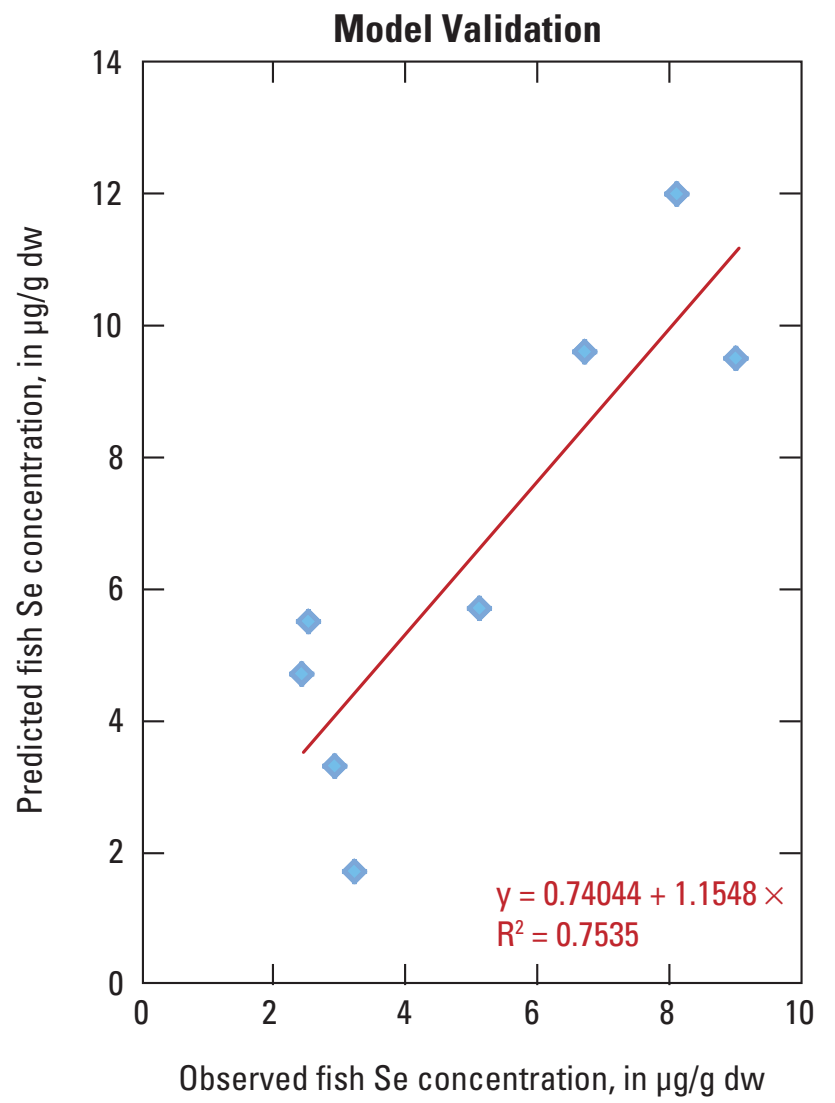

Figure 24. Graph showing linear regression and correlation of observed Se concentrations in fish (whole-body) and those concentrations predicted through ecosystem-scale modeling from observed particulate concentrations and the previously predicted invertebrate Se concentrations. 
Sites at Mud River upper, White Oak Creek, Seng Creek, Cabin Creek, Beech Creek, and the Birch River (food webs, figs. 16-19; data figs. 11-15; modeling tables 4 and 5) showed the highest observed Se concentrations in aquatic insects (range of observed species maxima: $11-25 \mu \mathrm{g} / \mathrm{g}$ $\mathrm{dw}$; range of mean or composite: $6.3-12 \mu \mathrm{g} / \mathrm{g}$ ) within the 2010-2011 assessed sites. Modeling of Se concentrations for aquatic insects was possible at only three of these sites (predicted range: $8.7-10.9 \mu \mathrm{g} / \mathrm{g}$ ).

Similarly, highest observed creek chub Se concentrations (range of observed maxima: 9.6-11.2 $\mu \mathrm{g} / \mathrm{g}$ wb dw; range of means: $6.0-9.0 \mu \mathrm{g} / \mathrm{g}$ ) were found at four of the sites where invertebrates were highest (that is, Mud River upper, White Oak Creek, Seng Creek, and Cabin Creek). An earlier sampling of White Oak Creek also showed maxima for green sunfish, creek chub, and stoneroller of 23.7, 12.8, and $12.8 \mu \mathrm{g} / \mathrm{g}(\mathrm{wb} \mathrm{dw})$, respectively; and means of 7.4, 5.8, and $7.1 \mu \mathrm{g} / \mathrm{g}$, respectively (fig. 10A). The range of predicted Se concentrations for Mud River upper, Seng Creek, and Cabin Creek was 9.5-12 $\mu \mathrm{g} / \mathrm{g}$ wb, with modeling not possible for White Oak Creek.

The other two sites with the highest Se concentrations in invertebrates showed observed Se concentrations in stoneroller reaching $6.9 \mu \mathrm{g} / \mathrm{g}$ wb at Beech Creek and those in creek chub reaching $7.5 \mu \mathrm{g} / \mathrm{g}$ wb at the Birch River. Modeling, however, was not possible for these sites. An earlier sampling of Beech Creek showed higher Se concentrations in fish than reported here for that site in 2011(maxima: green sunfish, $12.8 \mu \mathrm{g} / \mathrm{g}$ wb; creek chub, 17.2 $\mu \mathrm{g} / \mathrm{g}$ wb; stoneroller, $8.0 \mu \mathrm{g} / \mathrm{g} \mathrm{wb}$ ) (fig. 10).

Sites with intermediate observed Se concentrations in aquatic insects $(3.8-7.5 \mu \mathrm{g} / \mathrm{g})$ and fish $(2.4-8.0 \mu \mathrm{g} / \mathrm{g})$ were Twentymile Creek upper and lower; Clear Fork Creek upper and lower; and Mud River lower. The range of predicted aquatic insect Se concentrations was 4.7-7.1 $\mu \mathrm{g} / \mathrm{g}$ wb, and the range of predicted fish Se concentrations was $5.2-7.8 \mu \mathrm{g} / \mathrm{g}$ wb.

From earlier studies, the Upper Mud River Reservoir generated observed Se concentrations in invertebrates (dragonfly, crayfish, and clam) of 7.8 to $39 \mu \mathrm{g} / \mathrm{g}$ and showed a modeled range of 10.7-26.8 $\mu \mathrm{g} / \mathrm{g}$ (figs. 8 and 11; table 4). A literature-derived $\mathrm{TTF}_{\text {snail }}$ was not available for modeling, but the observed Se concentration in an snail was $36.6 \mu \mathrm{g} / \mathrm{g}$. Fish (bluegill sunfish, green sunfish, largemouth bass) Se concentrations in the reservoir were in the range of 3.2-60 $\mu \mathrm{g} / \mathrm{g}$ (wb dw) (figs. 8 and 11; table 4). Modeled fish Se concentrations were in the range of $11.8-40.5 \mu \mathrm{g} / \mathrm{g}$ ( $\mathrm{wb} \mathrm{dw}$ ), depending on invertebrate diet (table 5). Thus, modeling here, using nontemporally matched datasets for media components, quantified approximately 67 percent of the total measured maximum Se body burden of $60 \mu \mathrm{g} / \mathrm{g}$ in all fish collected. The maximum bluegill sunfish concentration was recorded in December 2006.

Similarly to results from earlier studies, the predicted Se bioaccumulation in fish for the Mud River (2005-2009, upper and mile 75.6 combined) was $21 \mu \mathrm{g} / \mathrm{g}$ dw based on a single component diet (that is, aquatic insect) (figs. 9C and
11; table 5). For species comparison, the ranges of measured Se concentration ( $\mathrm{wb} \mathrm{dw}$ ) during that time were: bluegill sunfish, 4.9-17.3 $\mu \mathrm{g} / \mathrm{g}$ (mean 10.9); green sunfish, 1.3-19.4 $\mu \mathrm{g} / \mathrm{g}$ (mean $7.9 \mu \mathrm{g} / \mathrm{g}$ ); creek chub $0.5-10.1 \mu \mathrm{g} / \mathrm{g}$ (mean $5.4 \mu \mathrm{g} / \mathrm{g}$ ); and stoneroller 3.3-5.0 $\mu \mathrm{g} / \mathrm{g}$ (mean $4.3 \mu \mathrm{g} / \mathrm{g}$ ) (figs. 9C, 11, and 12; table 5). Thus, the modeled potential for bioaccumulation in fish reached $21 \mu \mathrm{g} / \mathrm{g} \mathrm{dw}$, whereas the observed maximum was $19 \mu \mathrm{g} / \mathrm{g} \mathrm{dw}$ in green sunfish for nontemporally matched datasets during 2005-2009. This example used a compilation of data from 2005-2009 and showed Se concentrations for several species of fish collected at that time for a Mud River upper site. For comparison to a 2011 sampling for the river site, creek chub, the only fish species sampled, showed a maximum observed Se concentration of $11 \mu \mathrm{g} / \mathrm{g}$ and a mean concentration of $9.0 \mu \mathrm{g} / \mathrm{g}$ (figs. 11and 16) (see also calculation and applicability of site-specific $\mathrm{TTF}_{\text {creek chub }}$ in next section). Use of comprehensively matched datasets would most likely improve modeling accuracy at these sites.

\section{Site-Specific TTFs}

Calculation of site-specific TTFs for invertebrates and fish requires careful categorization to avoid unwarranted generalizations across sites or species. Using available combinations of measured suspended-particulate-material and mean or composite invertebrate Se concentrations from 2011, a mean site-specific $\mathrm{TTF}_{\text {invertebrate }}$ of 2.5 was calculated with a range of 1.5-3.6 (table 4). When sites with relatively low environmental Se concentrations (that is, dissolved Se concentrations of $<1 \mu \mathrm{g} / \mathrm{L}$; mean fish Se concentrations of $<3.2 \mu \mathrm{g} / \mathrm{g} \mathrm{wb} \mathrm{dw}$ ) were eliminated from consideration, then a mean site-specific $\mathrm{TTF}_{\text {invertebrate }}$ of 2.6 was calculated, with a range of 2.0 to 2.6. Including single taxon invertebrate Se concentrations with mean and composite concentrations in 2011, a slightly higher mean site-specific $\mathrm{TTF}_{\text {invertebrate }}$ of 2.7 was calculated, with a range of 1.2-4.5. These TTFs agree well with the mean $\mathrm{TTF}_{\text {aquatic insect }}$ of 2.8 (range 2.3-3.2) reported in the literature (Luoma and Presser, 2009; Conley and others, 2009).

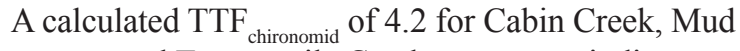
River upper, and Twentymile Creek upper may indicate a higher biotransfer of Se for this aquatic insect than that represented by a value of 2.7 reported in the literature (Presser and Luoma, 2010a). However, data for the derivation of the TTF for chironomid was limited to seven sites (table 4).

A mean site-specific $\mathrm{TTF}_{\text {fish }}$ of 0.81 (range $0.5-1.1$ ) was calculated using measured mean invertebrate and fish Se concentrations from 2011 [note: the Ash Fork site was eliminated as an outlier (that is, $\mathrm{TTF}_{\text {fish }}=4.0$ ) from this calculation and ones that follow; however, further investigation is needed to clarify the validity of this assumption] (table 5). When sites with relatively low environmental Se concentrations (that is, dissolved Se concentrations of $<1 \mu \mathrm{g} / \mathrm{L}$; mean fish Se concentrations of 
$<3.2 \mu \mathrm{g} / \mathrm{g} \mathrm{wb} \mathrm{dw}$ ) were eliminated from consideration, then a mean site-specific $\mathrm{TTF}_{\text {fish }}$ of 0.85 was calculated, with a range of 0.6-1.1. Including single-taxon invertebrate and fish tissue Se concentrations with mean and composite concentrations from the entire dataset from 2010 and 2011did not change the calculated $\mathrm{TTF}_{\text {fish }}$, but the rangewas then larger (0.3-2.7). Calculated site-specific TTF $_{\text {stoneroller }}$ from three datasets from two sites yielded lower values of $0.19,0.39$, and 0.48 (mean 0.35). Thus, most TTFs for creek chub and stoneroller were below the compiled species mean given in the literature of 1.1. This result (that is, $\mathrm{TTF}_{\text {fish }}<1$ ) shows a comparatively inefficient transfer from aquatic insect to creek chub and stoneroller (that is, Se concentrations in fish are less than those in their food) than that given in the literature for several species of fish (0.85 versus 1.1$)$.

Given the limited amount of data and the inclusion of incomplete (that is, not comprehensively linked) datasets, caution is advised in interpreting these site-specific values as representative of biotransfer of Se in a generalized setting for sampled basins. But, this analysis showed that for sampled invertebrates the range of calculated site-specific TTFs is narrow and is similar to those given in the literature.

For prey and predator TTFs at sites with dissolved Se concentrations of $<1 \mu \mathrm{g} / \mathrm{L}$ and mean fish Se concentrations of $<3.2 \mu \mathrm{g} / \mathrm{g}$ (wb dw), other processes may be involved that influence trophic transfer in low environmental Se environments. However, these low environmental Se sites would usually not be subjected to regulatory discussion or a modeling application (see later discussion in "Model Application" section). In the cases studied here, few sites and datasets were available to comprehensively research these processes (that is, elevation of TTFs in uncontaminated circumstances might be expected if Se is physiologically regulated at low environmental concentrations). Specifically for sites with low environmental Se concentrations, a calculated mean $\mathrm{TTF}_{\text {invertebrate }}$ was lower (2.3) and a calculated mean $\mathrm{TTF}_{\text {fish }}$ was higher (1.1) than the all-inclusive TTFs calculated above. Use of TTFs developed from studies of only systems that fall in the same order-of-magnitude range of Se concentrations as the one you want to model mitigates uncertainty in applicability in this regard.

\section{Conversion Factor: Whole-Body to Ovary}

The USEPA also is considering an ovary/egg Se criterion in addition to one for whole-body fish tissue (Green, 2009). Ovary Se concentrations are thought to be more directly linked to Se reproductive effects (Chapman and others, 2010). However, ovary Se concentrations, and hence conversion factors to whole-body, may be species-specific and also dependent on time of sampling (that is, ripeness of ovaries) (deBruyn and others, 2008; Osmundson and Skorupa, 2011). Ovary Se concentrations for creek chub and stoneroller were measured at USGS sites in spring of 2010 and 2011 (figs. 16-19). Conversion factors can be calculated based on site, basin, or species to facilitate use of ovary and whole-body fish tissue data. For southern West Virginia sites, mean whole-body and ovary Se concentrations were used in factor calculations, because separate samples were used for analysis of whole-body and ovary Se concentrations. The range of calculated conversion factors for whole-body to ovary was 1.1-2.2, with a mean conversion factor of 1.6. Calculated conversion factors for each site are shown in figs. 16-19. These values are similar to those given in the literature (range 1.3-2.4, DeForest and others, 2012). Data were limited at some sites, where only one or two samples were available to represent the site and calculate a conversion factor. Thus, these conversion factors should not be viewed as comprehensively derived.

Once validated, this type of conversion factor (cf) can then enhance modeling by having the capacity to model directly to ovary from suspended particulate material through invertebrate [for example, $\left(C_{\text {suspended particulate material }}\right)\left(\mathrm{TTF}_{\text {insect }}\right)$ $\left.\left(\mathrm{TTF}_{\text {fish wb }}\right)\left(\mathrm{cf}_{\text {wb-ovary }}\right)=C_{\text {fish ovary }}\right]$.

\section{Model Application}

Ecosystem-scale Se modeling is applied here to translate an assumed regulatory Se guideline or target for fish tissue $(\mathrm{wb} \mathrm{dw})$ to a dissolved Se concentration under a set of sitespecific exposure scenarios for the sampled basins (fig. 22; tables 8-11). As noted previously, figure 6 shows a schematic of the methodology, quantifying factors, and model equations. This type of application uses a metric describing site-specific partitioning of Se between particulate material and dissolved phases (that is, $\mathrm{K}_{\mathrm{d}}$ ) to link dissolved Se concentrations to the chosen Se toxicity guideline.

\section{Links to Dissolved Se Concentrations: $K_{d} s$}

Environmental partitioning between dissolved and particulate phases $\left(\mathrm{K}_{\mathrm{d}}\right)$ can be used to operationally characterize the outcome of biological uptake and transformation (commonly termed bioconcentration) of dissolved Se into the base of the food web. As previously defined, $\mathrm{K}_{\mathrm{d}}$ is not an equilibrium constant, but is an environmental partitioning factor dependent on site hydrology, Se speciation, and type of particulate material (Luoma and Presser, 2009; Presser and Luoma, 2006, 2010a,b). It is the ratio of the particulate-material Se concentration (in $\mathrm{dw}$ ) to the dissolved Se concentration observed at any instant. The specific equation is

$$
K_{\mathrm{d}}=\left(C_{\text {particulate material }}, \mu \mathrm{g} / \mathrm{kg} \mathrm{dw}\right) \div\left(C_{\text {water }}, \mu \mathrm{g} / \mathrm{L}\right)
$$

Dissolved or water-column Se in the water column can be specified in the derivation of $\mathrm{K}_{\mathrm{d}}$ for modeling to accommodate using existing datasets, but this substitution 
is a possible source of variability (Luoma and Rainbow, 2008). As sampled in the environment, components at the base of the food web include phytoplankton, periphyton, detritus, inorganic suspended material, biofilm, sediment, and (or) attached vascular plants. Consideration of the feeding characteristics of the invertebrate in the modeled food web helps narrow the focus for sampling and provides a consistent link of $\mathrm{K}_{\mathrm{d}}$ to the higher trophic level organisms modeled. For example, filter-feeding aquatic insects consume significant quantities of suspended particulate material, including living organisms and both organic and inorganic detritus (Wallace and Merritt, 1980). Suspended particulate material (in $\mu \mathrm{g} / \mathrm{g} \mathrm{dw}$ ) may be a preferred parameter for modeling because of its integrative nature.

As discussed previously, some generalizations are possible about partitioning and, hence, $\mathrm{K}_{\mathrm{d}} \mathrm{s}$ for Se (Presser and Luoma, 2010a). For example, exposure time (or residence time) for phase transformation and the fraction of organo-Se present are important variables driving differences among $\mathrm{K}_{\mathrm{d}} \mathrm{s}$ for such systems as streams and reservoirs. If all other conditions are the same, $K_{d}$ will increase as selenite and dissolved organo-Se concentrations increase (even if that increase is small). Experimental data support this conclusion. Calculations using data from laboratory microcosms and experimental ponds showed speciation-specific $\mathrm{K}_{\mathrm{d}} \mathrm{s}$ of 140 493 where selenate is the dominant form; $720-2,800$ when an elevated proportion of selenite exists; and 12,197-36,300 for 100-percent dissolved seleno-methionine uptake into algae or periphyton (Besser and others, 1989; Graham and others, 1992; Kiffney and Knight, 1990).

Thus, determining an environmental partitioning factor $\left(\mathrm{K}_{\mathrm{d}}\right)$ to link a dissolved Se concentration to a particulate Se concentration is an exacting challenge. Local data can narrow the range of $\mathrm{K}_{\mathrm{d}} \mathrm{s}$, as long as these data are highquality analytical data. In any case, it is critical that the range of calculated $\mathrm{K}_{\mathrm{d}}$ and the conditions under which they were measured be made explicit and the potential variability in this crucial factor be recognized. In the absence of well-developed biogeochemical site models, the choice of $\mathrm{K}_{\mathrm{d}}$ is usually the greatest source of uncertainty among model parameters.

For sampling in southern West Virginia, several limitations applied in deriving the terms for the calculation of $K_{d}$. As noted previously, suspended-particulate-material Se concentrations were not available in 2010 because of an analysis error, so only data from the 2011 sampling were available for this application. Only one type of particulate material was collected, with focus on suspended particulate material as an integrator of organic-rich fine-grained biomass. However, the quantity of material available for analysis was small, thereby possibly limiting the representativeness of the aliquot analyzed as it pertains to variability across streams. In this regard, streams may provide a different sampling opportunity from lakes and reservoirs: lakes and reservoirs may have a more stable suspended-particulate-material population and, thus, present a more temporally consistent sampling opportunity. The analysis preparation methodology for the suspendedparticulate-material phase was not the same for USGS sampling in 2008 and 2011 (centrifugation versus filtration, respectively). Streams and rivers especially may vary in the number of particulate phases and the contribution of those phases to a suspended-particulate-material composite. For example, a stream during a relatively high discharge season (that is, February-March) may contain only one particulate phase of limited Se bioavailability, but that stream during a relatively low discharge season (that is, June) may contain a richer set of particulate phases that have had time to reestablish during spring and summer. As discussed previously, longer residence times allow for greater uptake of Se in particulate phases, which is accompanied by greater recycling of selenite and organo-Se back into solution, further accelerating uptake (Bowie and others, 1996; Lemly, 2002; Meseck and Cutter, 2006).

Thus, for the study here, few $\mathrm{K}_{\mathrm{d}} \mathrm{s}$ (table 6) were available to represent the totality of environmental conditions reflected within particulate and dissolved phases across seasons or residence times. Data have shown that there can be considerable variability in dissolved Se concentration (for example, Upper Mud River basin, see figs. 7 and 21A) and in Se speciation (figs. 16-19) at a site. Additional sampling and analysis of particulate material would add to the database of $\mathrm{K}_{\mathrm{d}} \mathrm{s}$ available to model the streams of southern West Virginia (see also "Model Refinements and Reduction in Uncertainty" section).

Calculated $\mathrm{K}_{\mathrm{d}} \mathrm{s}$ for different sites sampled during June 2008, February-March 2011, and June 2011 are shown in table 6 (see also figs. 11-15). Measured dissolved and suspendedparticulate-material Se concentrations are shown as the basis for the calculations. To enhance modeling, a range of $\mathrm{K}_{d} \mathrm{~S}$ was calculated using the particulate Se concentration and the range of dissolved Se concentrates measured at each site to show the possible variation (that is, upper and lower bounds, table 6) across the monitoring periods. Calculated ranges of $\mathrm{K}_{\mathrm{d}} \mathrm{s}$ for the sampled watersheds are:

- Gauley River watershed: Twentymile Creek basin (2011 $\mathrm{K}_{\mathrm{d}}$ ranges: $\mathrm{TCLO}=520-1,250 ;$ TCUP $=372-760$ )

- Coal River watershed: Clear Fork basin $\left(2011 \mathrm{~K}_{\mathrm{d}}\right.$ : Seng Creek $=180)\left(K_{\mathrm{d}}\right.$ range: $\left.\mathrm{CFLO}=567-1,417\right)$

- Guyandotte River watershed: Upper Mud River basin (2008 $\mathrm{K}_{\mathrm{d}}$ range $\left.957-1,811\right)$

- Guyandotte River watershed: Upper Mud River basin $\left(2008 \mathrm{~K}_{\mathrm{d}}\right.$ ranges: $\mathrm{MRLO}=156-379$; $\left.\mathrm{MRUP}=129-386\right)$

- Upper Kanawha River watershed: $\left(2011 \mathrm{~K}_{\mathrm{d}}\right.$ : Cabin Creek $=505$ )

Mining-affected sites where suspended-particulatematerial Se concentrations were not available for calculation of $K_{d}$ were White Oak Creek, Beech Creek, and Birch River (table 6). 
Dissolved speciation (percent selenate, selenite, and organo-Se) data also are included to give insight into seasonal transformation conditions (table 6). Peaks in percentage of selenite and organo-Se are highlighted (table 6, noted in bold) and mainly occur during the April through August samplings. The lowest percentages of selenate were measured at Twentymile Creek lower and Clear Fork lower during April 2010. Note also that the Upper Mud River Reservoir in August 2006 contained 96 percent selenate, but that the tailwater exiting the reservoir contained 91 percent selenate. Additional data would be needed to confirm trends and develop a comprehensive view of transformation and partitioning across seasons and basins.

Sites with low observed Se concentrations (dissolved $<0.06$ to $0.68 \mu \mathrm{g} / \mathrm{L}$ ) are not included in the regulatory discussion or application here because, overall, propagation of Se concentrations up the aquatic insect-based food webs of these sites resulted in low Se risk (mean creek chub, 2.4 to $3.2 \mu \mathrm{g} / \mathrm{g} \mathrm{wb}$ ) (table 7). These sites are: Ash Fork, Sycamore Creek, Clear Fork upper, left fork Mud River, and Upton Branch. Modeling and predictions from particulate Se concentrations at these sites resulted in good agreement between modeled Se concentrations and observed Se concentrations in invertebrates and fish (for example, predicted fish: 1.7-5.5 $\mu \mathrm{g} / \mathrm{g}$ wb) (tables 4, 5, 7; figs. 23 and 24). Thus, model parameters, linkages, and outcomes are ecologically consistent across media for these sites with low environmental Se concentrations. If monitoring of these sites continues and the upper range of Se concentrations in invertebrate and fish samples is found to expand, or Se data from other fish species inhabiting these sites become available, then further investigation is recommended to quantify Se risk.

\section{Derivation of Dissolved Selenium Concentrations}

\section{Site-Specific Application}

The generalized equation for translation of a fish tissue Se concentration to a water-column Se concentration is

$$
C_{\text {water }}=C_{\text {fish }} \div\left(\mathrm{TTF}_{\text {fish }}\right)\left(\mathrm{TTF}_{\text {invertebrate }}\right) \mathrm{K}_{\mathrm{d}}
$$

where $\left(\mathrm{K}_{\mathrm{d}}\right)\left(C_{\text {water }}\right)$ is substituted for $C_{\text {particulate }}$ in equation 11 and the equation is solved for $C_{\text {water }}$ (fig. 6). This application and site-specific examples illustrated here are dependent not only on Se concentrations in a predator, but on the choice of the predator species and its food web that is modeled and the hydrologic setting that is specified. Agencies have traditionally regulated contaminants on the basis of water-column concentrations and managed inputs from different sources based upon their implications for those concentrations (for example, total mass daily loadings). The application and exposure scenarios developed here tie the new concept of tissue guidelines to the traditional concept of management based on water-column concentration s. In the case presented here, a dissolved Se concentration rather than a total Se concentration from a combined water-column sample is used because of the importance of phase transformation to the basic mechanisms of Se uptake at the base of food webs. However, for regulatory purposes, a generalized translator is available (that is, dissolved Se to total recoverable Se) (USEPA, 1996).

The Se effect guidelines chosen for evaluation in the exposure scenarios were 5.0 and $7.9 \mu \mathrm{g} / \mathrm{g}$ fish (wb $\mathrm{dw}$ ) (tables 8-11). The regulatory community is debating appropriate critical tissue values that relate bioaccumulated Se concentrations and toxicity in predators (Chapman and others, 2010). These choices for guidelines are within the range of those that are being discussed, but use of these guidelines in exposure scenarios should not be considered an endorsement of these values. As stated previously, the fish-tissue target of $7.9 \mu \mathrm{g} / \mathrm{g}$ (wb dw) was proposed by USEPA in 2004. The fish-tissue target of $5 \mu \mathrm{g} / \mathrm{g}$ ( $w b ~ d w)$ was derived to provide additional protection for adherence to both the Clean Water Act and the Endangered Species Act (Skorupa and others, 2004; USFWS, 2005). This estimate of the threshold guideline is required to provide full protection for individuals of even Se-sensitive species of threatened or endangered fish. Designation of a limit of toxicity (for example, the percentage of the population that is expected to be affected) is an important quantitative aspect of any guideline. A fish-ovary target could be built into the model through direct connection of diet to ovary Se concentrations or through use of a conversion factor to calculate a wb or muscle Se concentration from the designated ovary guideline (see earlier detailed discussion in "Conversion Factor: Whole-Body to Ovary" section).

Quantitative exposure scenarios show possible, ecologically realistic food webs within the hydrologic setting of sampled basins (fig. 22, tables 8-11). Modeling scenarios are specific to food webs expected within each hydrologic setting, but they include a base-case food web of suspended particulate material to aquatic insect $\left(\mathrm{TTF}_{\text {invertebrate }}=2.8\right)$ to creek chub $\left(\mathrm{TTF}_{\text {fish }}=1.1\right)$ as a common linkage between hydrologic settings. Alternative site-specific species of fish are listed (for example, green sunfish, bluegill sunfish), but additional analysis would be necessary to allow further species-specific dietary consideration. The food webs illustrated here for stream settings also include (1) suspended particulate material to freshwater clam (C. fluminea) to white sucker; (2) suspended particulate material to chironomid to rainbow darter; and (3) suspended particulate material to stoneroller without an invertebrate transfer step (tables 8-11). For a reservoir setting, food webs include suspended particulate material to a variety of invertebrates [crayfish, freshwater clam (C. Aluminea), snail (Planorbidae)] and fish (bluegill sunfish, green sunfish, redear sunfish, largemouth bass) species. Modeling within stream and reservoir settings also differentiates food webs for young and adult fish, 
Table 6. Dissolved and suspended-particulate-material Se concentrations and Se speciation data as a basis for preliminary calculation of environmental partitioning factors $\left(\mathrm{K}_{\mathrm{d}} \mathrm{s}\right)$ for June 2008, February-March 2011, and June 2011.

[Peaks in percentage of selenite $\left(\mathrm{SeO}_{3}\right)^{\prime}$ ) and organo-Se (org-Se) in bold; $\mu \mathrm{g} / \mathrm{L}$, micrograms per liter; $\mu \mathrm{g} / \mathrm{g}$ dw, micrograms per gram dry weight; *assumed an outlier]

\begin{tabular}{|c|c|c|c|c|c|c|c|c|c|}
\hline \multirow[b]{2}{*}{ Date } & \multirow[b]{2}{*}{ Field site } & \multirow[b]{2}{*}{$\begin{array}{l}\text { Field } \\
\text { name }\end{array}$} & \multirow[b]{2}{*}{$\mathbf{K}_{\mathbf{d}}$} & \multirow[b]{2}{*}{$\begin{array}{l}\text { Dissolved } \\
\text { Se, in } \mu \mathrm{g} / \mathrm{L}\end{array}$} & \multirow{2}{*}{$\begin{array}{c}\text { Suspended } \\
\text { particulate } \\
\text { material Se, } \\
\text { in } \mu \mathrm{g} / \mathrm{g} \mathrm{dw}\end{array}$} & \multirow{2}{*}{$\begin{array}{c}\text { Dissolved } \\
\text { Se, in } \mu g / L \\
\text { (range) }\end{array}$} & \multicolumn{3}{|c|}{ In percent } \\
\hline & & & & & & & $\mathrm{SeO}_{4}=$ & $\mathrm{SeO}_{3}=$ & org-Se \\
\hline
\end{tabular}

\section{Mining-affected sites with calculated $\mathrm{K}_{\mathrm{d}} \mathrm{s}$}

Gauley River watershed: Twentymile Creek basin (2011 K ${ }_{d}$ ranges: TCLO = 520-1,250; TCUP = 372-760)

\begin{tabular}{|c|c|c|c|c|c|c|c|c|}
\hline $\begin{array}{c}\text { Feb-Mar } 2011 \\
\text { Apr } 2010 \\
\text { Aug } 2010 \\
\text { Nov } 2010\end{array}$ & Twentymile Creek lower & $\begin{array}{l}\text { TCLO } \\
\text { TCLO } \\
\text { TCLO } \\
\text { TCLO }\end{array}$ & 793 & 3.2 & 2.5 & $2.0-4.8$ & $\begin{array}{l}93 \\
82 \\
83 \\
99\end{array}$ & $\begin{array}{l}2 \\
3 \\
8 \\
8\end{array}$ \\
\hline $\begin{array}{c}\text { Feb-Mar } 2011 \\
\text { May2010 } \\
\text { Aug } 2010 \\
\text { Nov } 2010\end{array}$ & Twentymile Creek upper & $\begin{array}{l}\text { TCUP } \\
\text { TCUP } \\
\text { TCUP } \\
\text { TCUP }\end{array}$ & 505 & 3.7 & 1.9 & $2.5-5.1$ & $\begin{array}{l}95 \\
88 \\
84 \\
92\end{array}$ & $\begin{array}{l}0 \\
4 \\
5 \\
7\end{array}$ \\
\hline
\end{tabular}

Coal River watershed: Clear Fork basin $\left(2011 \mathrm{~K}_{\mathrm{d}}\right.$ : Seng Creek $\left.=180\right)\left(\mathrm{K}_{\mathrm{d}}\right.$ range: CFL0 $\left.=567-1,417\right)$

\begin{tabular}{|c|c|c|c|c|c|c|c|c|c|}
\hline Jun 2011 & Seng Creek & SECR & 180 & 23.3 & 4.2 & & 89 & 3 & 9 \\
\hline Feb-Mar 2011 & Clear Fork lower & CFLO & 867 & 2.0 & 1.7 & $1.2-3.0$ & $>100$ & 0 & 0 \\
\hline Apr 2010 & & CFLO & & & & & 82 & 5 & 13 \\
\hline Aug 2010 & & CFLO & & & & & 83 & 11 & 0 \\
\hline Nov 2010 & & CFLO & & & & & 76 & 14 & 10 \\
\hline
\end{tabular}

2006-2008 Guyandotte River watershed: Upper Mud River basin (2008 $K_{d}$ range: 957-1,811)

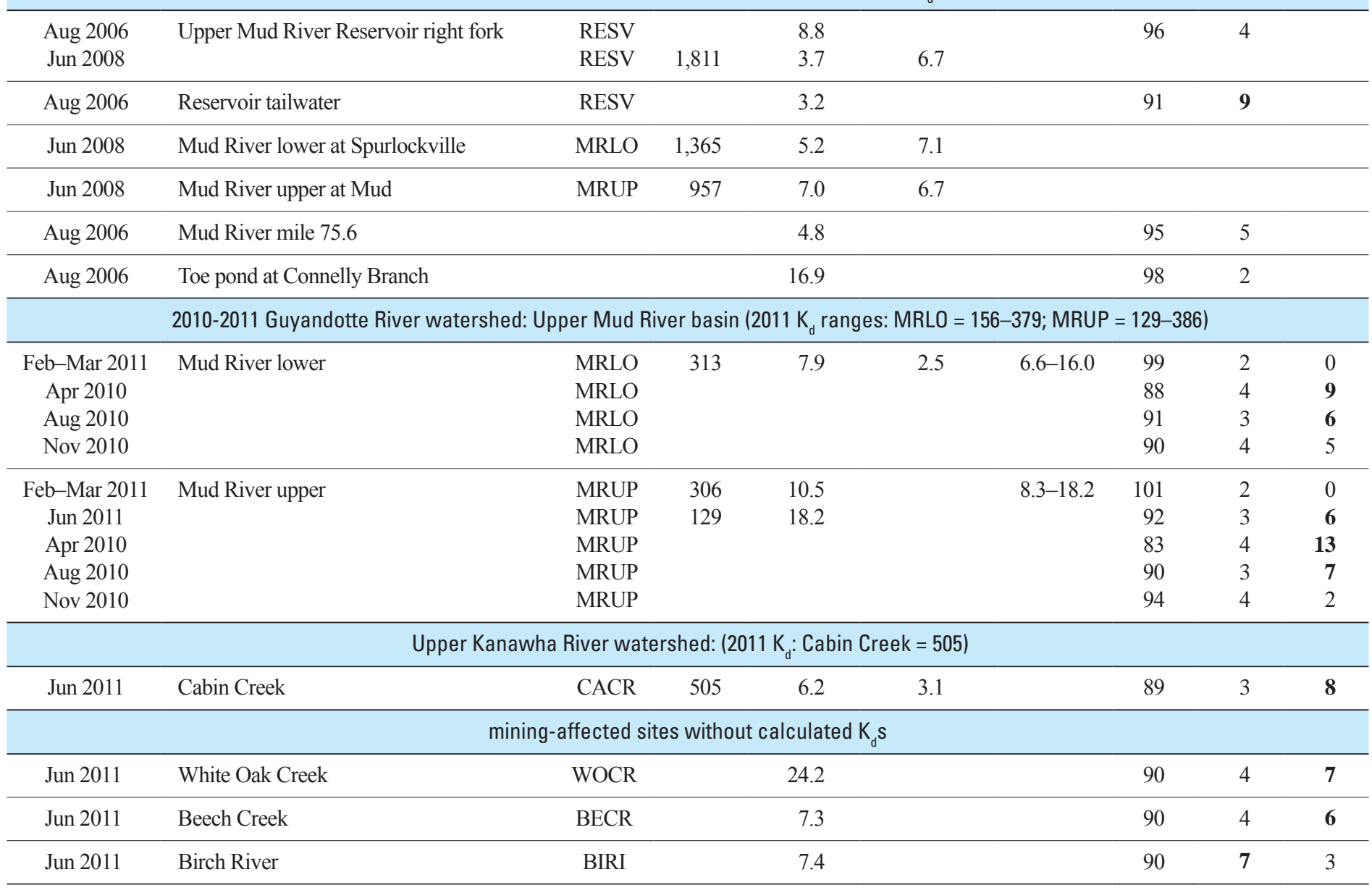


Table 7. Food-web Se concentrations (observed and predicted) for sites not included in regulatory translation discussion (low environmental Se: dissolved $<1 \mu \mathrm{g} / \mathrm{L}$ and mean fish $<3.2 \mu \mathrm{g} / \mathrm{g}$ wb dw).

[ $\mu \mathrm{g} / \mathrm{L}$, micrograms per liter; $\mu \mathrm{g} / \mathrm{g}$ dw, micrograms per gram dry weight; wb, whole body; predicted values in blue]

\begin{tabular}{|c|c|c|c|c|c|c|c|c|}
\hline \multirow[b]{2}{*}{ Date } & \multirow[b]{2}{*}{ Field site } & \multirow[b]{2}{*}{$\begin{array}{l}\text { Field } \\
\text { name }\end{array}$} & \multirow[b]{2}{*}{$\begin{array}{l}\text { Dissolved } \\
\text { Se, in } \mu g / L \\
\text { (range) }\end{array}$} & \multicolumn{5}{|c|}{ Se, in $\mu g / g d w$} \\
\hline & & & & $\begin{array}{c}\text { Suspended } \\
\text { particulate } \\
\text { material }\end{array}$ & $\begin{array}{c}\text { Mean } \\
\text { invertebrate }\end{array}$ & $\begin{array}{l}\text { Predicted } \\
\text { invertebrate }\end{array}$ & $\begin{array}{l}\text { Mean fish } \\
\text { (wb) }\end{array}$ & $\begin{array}{l}\text { Predicted } \\
\text { fish (wb) }\end{array}$ \\
\hline Jun 2011 & Ash Fork & TCAF & $<0.06-0.21$ & 0.55 & 0.8 & 1.5 & 3.2 & 1.7 \\
\hline Jun 2011 & Sycamore Creek & CFSC & $0.18-0.63$ & 1.06 & 3.9 & 3.0 & 2.8 & 3.3 \\
\hline $\begin{array}{c}\text { Feb-Mar } 2011 \\
\text { Jun } 2011\end{array}$ & Clear Fork upper & $\begin{array}{l}\text { CFUP } \\
\text { CFUP }\end{array}$ & $0.15-0.68$ & $\begin{array}{l}1.8 \\
0.72\end{array}$ & 4.7 & 5.0 & 2.5 & 5.5 \\
\hline $\begin{array}{c}\text { Feb-Mar } 2011 \\
\text { Jun } 2011\end{array}$ & left fork Mud River & $\begin{array}{l}\text { MRLF } \\
\text { MRLF }\end{array}$ & $<0.06-0.23$ & $\begin{array}{l}1.6 \\
2.2\end{array}$ & 3.0 & 4.3 & 2.4 & 4.7 \\
\hline Jun 2011 & Upton Branch & MRUB & $0.10-0.18$ & 0.58 & 2.0 & 1.6 & 3.2 & 1.8 \\
\hline
\end{tabular}

with the diet of adults including transfer from young fish in addition to invertebrate (that is, three-step modeling). Variations throughout the scenarios also include a food web that has a lower $\mathrm{TTF}_{\text {fish }}$ of 0.7 . The site-specific $\mathrm{TTF}_{\text {fish }}$ developed here of 0.85 was lowered to 0.7 to include a TTF that may represent the lower end of the range (that is, an endmember) for biotransfer to fish from invertebrates. As noted previously, many combinations of food webs and hydrology are possible. A range of predicted Se concentrations are given here to illustrate site-specific exposure scenarios, but the overall outcomes and implications will be those generated by modeling choices and guidance given by WVDEP or other agencies in their decisionmaking processes.

Overlain onto the choices of food-web species in the illustrated scenarios are a suite of $\mathrm{K}_{\mathrm{d}} \mathrm{s}$ that are specific to time (June 2008 or 2011; February-March 2011) and location. For different streams, the illustrated $\mathrm{K}_{\mathrm{d}} \mathrm{s}$ are:

- 180 and 505 during June 2011 (Seng and Cabin Creeks, respectively)

- 957 and 1,365 during June 2008 (Mud River upper and lower, respectively)

- 310, 505, 793, and 867 during February-March 2011 (Mud River combined upper and lower; Twentymile Creek upper and lower; and Clear Fork lower, respectively)

These values are within the range of $\mathrm{K}_{\mathrm{d}} \mathrm{s}$ measured during 2010 and 2011 for each site (table 6).

For the Upper Mud River Reservoir in June 2008, the illustrated $\mathrm{K}_{\mathrm{d}} \mathrm{s}$ is 1,800 . A sedimentation pond scenario also is included because this type of hydrologic setting is common within a basin or watershed. Few data exist for sedimentation ponds: a dissolved Se concentration of $16.9 \mu \mathrm{g} / \mathrm{L}$ measured in August 2006 (WVDEP, 2010) and several dissolved Se concentrations (24, 26, 34, 37, 42 $\mu \mathrm{g} / \mathrm{L}$ ) measured during 2000-2001 (Bryant and Childers, 2002). For sedimentation ponds at the toe of valley fills, two hypothetical $\mathrm{K}_{\mathrm{d}} \mathrm{s}$ are illustrated: 600 and 900 , based on the range of $\mathrm{K}_{\mathrm{d}} \mathrm{s}$ for ponds and reservoirs reported in Presser and Luoma (2010a). However, these scenarios should be viewed with caution until the food webs and hydrologic conditions of these types of impoundments are investigated within southern West Virginia.

Limited data and sampling seasons necessitate caution in extrapolating results of (1) an individual sampling event to a generalized condition across low and high discharge conditions and (2) an individual site to a generalized condition across a basin. Specifically in the methodology for streams used here, it was decided not to generalize streams or basins in terms of $\mathrm{K}_{\mathrm{d}}$ because of the limitations of the dataset and its linkage to discharge measurement (that is, residence time) or other locational and hydrological variables (area of stream basin; stream gradient; seasonal patterns of Se source dynamics). Hence, exposure scenarios are explicitly tied to site- and time-specific field-derived $\mathrm{K}_{\mathrm{d}} \mathrm{s}$ for prediction of dissolved Se concentrations (figs. 25-28). Sampling in the future could focus on expanding the type of analysis shown here and differentiating predictions across specified discharge and load conditions.

For a fish- tissue guideline of $7.9 \mu \mathrm{g} / \mathrm{g}$ ( $w b \mathrm{dw}$ ), the range of predicted dissolved Se concentrations is 1.9 to 14.2 $\mu \mathrm{g} / \mathrm{L}$ for the base-case food web (suspended particulate material to insect to fish) and the June 2008 and 2011 set of stream sites and their associated $\mathrm{K}_{\mathrm{d}} \mathrm{s}$ (tables 8 and 9). The predicted range is $3.0-8.3 \mu \mathrm{g} / \mathrm{L}$ for the base-case food web and the February-March 2011 set of sites and their associated $\mathrm{K}_{\mathrm{d}} \mathrm{s}$ (tables 8 and 9). If the predictions are constrained to $\mathrm{K}_{\mathrm{d}} \mathrm{s}>310$, then the range of dissolved Se concentrations for the basecase food web across all sites is narrowed to $1.9--5.1 \mu \mathrm{g} / \mathrm{L}$. Deviations from the base-case food web across the range of hydrologic conditions in streams shows that inclusion of

- a clam or chironomid food web would decrease predicted dissolved Se concentrations (ranges: June, 1.3-10 $\mu \mathrm{g} / \mathrm{L}$; February-March , 2.1-5.8 $\mu \mathrm{g} / \mathrm{L})$; 
- a forage fish to predator fish food web would decrease predicted dissolved Se concentrations (ranges: June, $1.7-13 \mu \mathrm{g} / \mathrm{L} ;$ February-March , 2.7-7.5 $\mu \mathrm{g} / \mathrm{L})$

- a particulate to stoneroller food web would increase predicted dissolved Se concentrations (ranges: June, 5.3-40 $\mu \mathrm{g} / \mathrm{L} ;$ February-March , 8.3-23 $\mu \mathrm{g} / \mathrm{L})$

- a $\mathrm{TTF}_{\text {fish }}$ of $<1$ (that is, indicating a comparatively inefficient transfer from aquatic insect to creek chub or stoneroller) would increase predicted dissolved Se concentrations (ranges: June, 3.0-22 $\mu \mathrm{g} / \mathrm{L}$; February-March , $4.6-13 \mu \mathrm{g} / \mathrm{L})$.

If the site-specific, field-derived $\mathrm{TTF}_{\text {snail }}$ of 5.5 is used in predictive scenarios, then a food web that includes snails would decrease the predicted dissolved Se concentrations even further than those values derived for clam or chironomid food webs.

The food webs for reservoirs and ponds include species other than those found in streams (fig. 22). The range of predicted dissolved Se concentrations is $0.7-2.5 \mu \mathrm{g} / \mathrm{L}$ for food webs for the Upper Mud River Reservoir in June 2008 (tables 8 and 9). The range of predicted dissolved Se concentrations for valley-fill ponds is $2.0-4.5 \mu \mathrm{g} / \mathrm{L}$ in summer and 3.0-6.7 $\mu \mathrm{g} / \mathrm{L}$ in winter (tables 8 and 9). If only a base-case food web (note: bluegill is substituted for creek chub, with TTF $_{\text {fish }}$ remaining at 1.1, fig. 22) is considered in a reservoir setting, the predicted dissolved Se concentration is $1.4 \mu \mathrm{g} / \mathrm{L}$. For a pond setting, the predicted dissolved Se concentration is $2.8 \mu \mathrm{g} / \mathrm{L}$ in summer and $4.3 \mu \mathrm{g} / \mathrm{L}$ in winter. The controlling food-web variables for the most restrictive dissolved Se concentrations in these hydrologic settings are $\operatorname{TTF}_{\text {snail }}(0.7 \mu \mathrm{g} / \mathrm{L})$ and a possible increased efficiency for $\mathrm{TTF}_{\text {bluegill }}(1.2 \mu \mathrm{g} / \mathrm{L})$.

Predicted dissolved Se concentrations for the illustrated food webs and a fish-tissue guideline of $5.0 \mu \mathrm{g} / \mathrm{g}$ (wb dw) showed possible protection for endangered species (tables 10 and 11). Selenium concentrations are proportional, but lower than discussed above. For example, the highest predicted Se concentrations forecasted is $25 \mu \mathrm{g} / \mathrm{L}$ and the lowest is 0.5 $\mu \mathrm{g} / \mathrm{L}$ for the suite of illustrated scenarios.

From modeling, it is clear that reservoirs within basins and ponds at the toes of valley fills present the most consistent ecological Se risk based on hydrologic setting within a watershed. Modeled food webs that contain clams, chironomids, or snails, or contain an additional step to adult fish, also present consistent ecological Se risk based on species consuming a single component diet (fig. 22, tables 8-11; figs. 25-28). If there is a range of predator vulnerabilities (measured as a combination of food-web Se biodynamics and response in Se toxicity tests) within site-specific fish species to be protected, then choice of fish species is critical to protection because it determines the food web, and hence the magnitude of biotransfer, through which Se is modeled. Previous studies of Se concentrations in different fish species for the mountaintop coal mining area of southern West Virginia (figs. 8-10) did not address food-web components (that is, sampling of fish species dietary components). However, the studies showed hierarchical rankings for Se bioaccumulation based on the maximum bioaccumulative potential among fish species as (1) blacknose dace $\geq$ bluegill sunfish $>$ green sunfish $>$ creek chub > stoneroller in a combined river hydrologic setting; and (2) bluegill sunfish $>$ green sunfish $>$ largemouth bass in a reservoir hydrologic setting (see especially figs. $8 E, 9 B$, and $9 C$ ).

In contrast, mitigation of Se risk could occur in settings containing stonerollers directly consuming particulate material with no invertebrate step (that is, limitations in dietary choices). Risk also can be moderated in streams here because of hydrologic stream settings that may include varying residence times. Dissolved Se speciation also may vary, with selenite and organo-Se percentages increasing during spring and summer (table 6; figs. 11-15). Possible comparatively lower biotransfer from invertebrate to fish than that given in the literature for several species of fish ( 0.85 versus 1.1$)$ may be the case for creek chub and stoneroller. Thus, modeling outcomes that combine hydrologic settings and food-web species can help elucidate and quantify the basis of management alternatives for a watershed and fish community approach.

As noted previously, the model application and synopsis given here sets up a range of choices that can be specifically addressed to narrow outcomes based on the input of decisionmakers (tables 8-11). The parameters of those exposure scenarios are key to understanding the range of model outcomes. Further specificity is discussed in the following section on streams to elucidate a level of model framing to help understand, and possibly quantify, some of the underlying variables that affect $\mathrm{K}_{d} \mathrm{~s}$. This analysis has data limitations, but additional site-specific evaluation of hydrologic and landscape parameters in the future hopefully will help refine this approach.

\section{Streams Detail}

Schematics for streams where $\mathrm{K}_{\mathrm{d}} \mathrm{s}$ were available (tables 6 and 7) show predicted site-specific dissolved Se concentrations derived by using a fish-tissue guideline of $7.9 \mu \mathrm{g} / \mathrm{g}(\mathrm{wb} \mathrm{dw})$ for the base-case scenario of suspended particulate material to aquatic insect to creek chub (figs. 25-26; tables 8 and 9). Schematics and $\mathrm{K}_{\mathrm{d}} \mathrm{s}$ are specific to month and year (February 2011, June 2011, June 2008), which acknowledges a temporal component to the model application. Comparison of predicted dissolved Se concentrations to observed dissolved Se concentrations shows the magnitude of change necessary to adhere to the translated guideline. However, consideration of the variability of measured dissolved $\mathrm{Se}$ in the stream with time (figs 25-26) would be an additional factor for regulatory or managerial oversight. For the base-case scenario, predicted site-specific changes in dissolved Se concentrations for stream sites range from a possible increase of $1.4 \mu \mathrm{g} / \mathrm{L}$ for Twentymile Creek upper to a possible decrease of 
Table 8. Site-specific exposure scenarios: regulatory fish-tissue Se target of $7.9 \mu \mathrm{g} / \mathrm{g}(\mathrm{wb}$, dw) to dissolved Se concentrations specific to June 2008 and June 2011 hydrologic conditions.

[TTF, trophic transfer factor; $\mu \mathrm{g} / \mathrm{L}$, micrograms per liter; $\mu \mathrm{g} / \mathrm{g}$ dw, micrograms per gram dry weight; wb, whole body; *not regulated as "waters of the state"; NA not available; predicted values in blue]

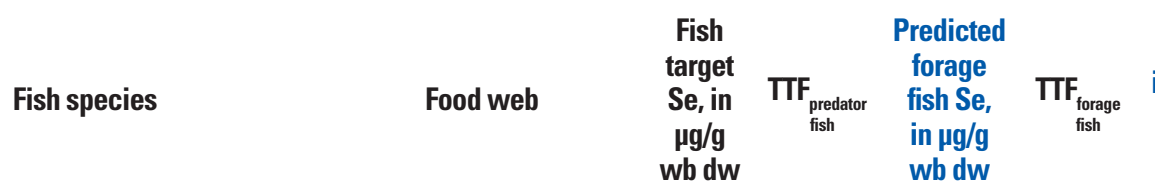
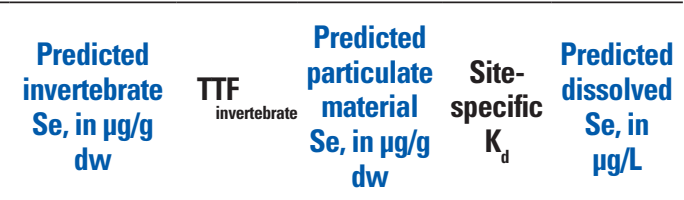

June valley-fill pond (hypothetical) ${ }^{*}$

\begin{tabular}{|c|c|c|c|c|c|c|c|c|c|c|}
\hline \multicolumn{11}{|c|}{ June valley-fill pond (hypothetical)* } \\
\hline creek chub & particulate to insect & 7.9 & 1.1 & NA & NA & 7.2 & 2.8 & 2.6 & 900 & 2.8 \\
\hline creek chub & particulate to insect & 7.9 & 0.7 & NA & NA & 11.3 & 2.8 & 4.0 & 900 & 4.5 \\
\hline green sunfish or bluegill sunfish & particulate to insect & 7.9 & 1.3 & NA & NA & 6.1 & 2.8 & 2.2 & 900 & 2.4 \\
\hline green sunfish & particulate to clam & 7.9 & 1.1 & NA & NA & 7.2 & 4.0 & 1.8 & 900 & 2.0 \\
\hline bluntnose minnow & particulate to chironomid & 7.9 & 1.1 & NA & NA & 7.2 & 4.0 & 1.8 & 900 & 2.0 \\
\hline young creek chub to adult fish & particulate to insect & 7.9 & 1.1 & 7.2 & 1.1 & 6.5 & 2.8 & 2.3 & 900 & 2.6 \\
\hline \multicolumn{11}{|c|}{ June 2011 stream (Seng Creek) } \\
\hline stoneroller & particulate & 7.9 & NA & NA & 1.1 & NA & NA & 7.2 & 180 & 39.9 \\
\hline young stoneroller to rock bass & particulate & 7.9 & 1.1 & 7.2 & 1.1 & NA & NA & 6.5 & 180 & 36.3 \\
\hline creek chub & particulate to insect & 7.9 & 1.1 & NA & NA & 7.2 & 2.8 & 2.6 & 180 & 14.2 \\
\hline creek chub & particulate to insect & 7.9 & 0.7 & NA & NA & 11.3 & 2.8 & 4.0 & 180 & 22.4 \\
\hline green sunfish or bluegill sunfish & particulate to insect & 7.9 & 1.3 & NA & NA & 6.1 & 2.8 & 2.2 & 180 & 12.2 \\
\hline white sucker & particulate to clam & 7.9 & 1.1 & NA & NA & 7.2 & 4.0 & 1.8 & 180 & 10.0 \\
\hline rainbow darter & particulate to chironomid & 7.9 & 1.1 & NA & NA & 7.2 & 4.0 & 1.8 & 180 & 10.0 \\
\hline young creek chub to adult rock bass & particulate to insect & 7.9 & 1.1 & 7.2 & 1.1 & 6.5 & 2.8 & 2.3 & 180 & 12.9 \\
\hline \multicolumn{11}{|c|}{ June 2011 stream (Cabin Creek) } \\
\hline stoneroller & particulate & 7.9 & NA & NA & 1.1 & NA & NA & 7.2 & 505 & 14.2 \\
\hline young stoneroller to rock bass & particulate & 7.9 & 1.1 & 7.2 & 1.1 & NA & NA & 6.5 & 505 & 12.9 \\
\hline creek chub & particulate to insect & 7.9 & 1.1 & NA & NA & 7.2 & 2.8 & 2.6 & 505 & 5.1 \\
\hline creek chub & particulate to insect & 7.9 & 0.7 & NA & NA & 11.3 & 2.8 & 4.0 & 505 & 8.0 \\
\hline green sunfish or bluegill sunfish & particulate to insect & 7.9 & 1.3 & NA & NA & 6.1 & 2.8 & 2.2 & 505 & 4.4 \\
\hline white sucker & particulate to clam & 7.9 & 1.1 & NA & NA & 7.2 & 4.0 & 1.8 & 505 & 3.6 \\
\hline rainbow darter & particulate to chironomid & 7.9 & 1.1 & NA & NA & 7.2 & 4.0 & 1.8 & 505 & 3.6 \\
\hline young creek chub to adult rock bass & particulate to insect & 7.9 & 1.1 & 7.2 & 1.1 & 6.5 & 2.8 & 2.3 & 505 & 4.6 \\
\hline \multicolumn{11}{|c|}{ June stream 2008 (Mud River upper) } \\
\hline stoneroller & particulate & 7.9 & NA & NA & 1.1 & NA & NA & 7.2 & 957 & 7.5 \\
\hline young stoneroller to adult rock bass & particulate & 7.9 & 1.1 & 7.2 & 1.1 & NA & NA & 6.5 & 957 & 6.8 \\
\hline creek chub & particulate to insect & 7.9 & 1.1 & NA & NA & 7.2 & 2.8 & 2.6 & 957 & 2.7 \\
\hline creek chub & particulate to insect & 7.9 & 0.7 & NA & NA & 11.3 & 2.8 & 4.0 & 957 & 4.2 \\
\hline green sunfish or bluegill sunfish & particulate to insect & 7.9 & 1.3 & NA & NA & 6.1 & 2.8 & 2.2 & 957 & 2.3 \\
\hline white sucker & particulate to clam & 7.9 & 1.1 & NA & NA & 7.2 & 4.0 & 1.8 & 957 & 1.9 \\
\hline rainbow darter & particulate to chironomid & 7.9 & 1.1 & NA & NA & 7.2 & 4.0 & 1.8 & 957 & 1.9 \\
\hline young creek chub to adult rock bass & particulate to insect & 7.9 & 1.1 & 7.2 & 1.1 & 6.5 & 2.8 & 2.3 & 957 & 2.4 \\
\hline \multicolumn{11}{|c|}{ June stream 2008 (Mud River lower) } \\
\hline stoneroller & particulate & 7.9 & NA & NA & 1.1 & NA & NA & 7.2 & 1,365 & 5.3 \\
\hline young stoneroller to rock bass & particulate & 7.9 & 1.1 & 7.2 & 1.1 & NA & NA & 6.5 & 1,365 & 4.8 \\
\hline creek chub & particulate to insect & 7.9 & 1.1 & NA & NA & 7.2 & 2.8 & 2.6 & 1,365 & 1.9 \\
\hline creek chub & particulate to insect & 7.9 & 0.7 & NA & NA & 11.3 & 2.8 & 4.0 & 1,365 & 3.0 \\
\hline green sunfish or bluegill sunfish & particulate to insect & 7.9 & 1.3 & NA & NA & 6.1 & 2.8 & 2.2 & 1,365 & 1.6 \\
\hline white sucker & particulate to clam & 7.9 & 1.1 & NA & NA & 7.2 & 4.0 & 1.8 & 1,365 & 1.3 \\
\hline rainbow darter & particulate to chironomid & 7.9 & 1.1 & NA & NA & 7.2 & 4.0 & 1.8 & 1,365 & 1.3 \\
\hline young creek chub to adult rock bass & particulate to insect & 7.9 & 1.1 & 7.2 & 1.1 & 6.5 & 2.8 & 2.3 & 1,365 & 1.7 \\
\hline \multicolumn{11}{|c|}{ June reservoir 2008 (Upper Mud River Reservoir) } \\
\hline bluegill or green sunfish & particulate to insect & 7.9 & 1.1 & NA & NA & 7.2 & 2.8 & 2.6 & 1,800 & 1.4 \\
\hline bluegill or green sunfish & particulate to insect & 7.9 & 1.3 & NA & NA & 6.1 & 2.8 & 2.2 & 1,800 & 1.2 \\
\hline redear sunfish or pumpkinseed sunfish & particulate to snail & 7.9 & 1.1 & NA & NA & 7.2 & 5.5 & 1.3 & 1,800 & 0.7 \\
\hline channel catfish or common carp & particulate to clam or snail & 7.9 & 1.1 & NA & NA & 7.2 & 4.0 & 1.8 & 1,800 & 1.0 \\
\hline largemouth bass & particulate to crayfish & 7.9 & 1.1 & NA & NA & 7.2 & 1.6 & 4.5 & 1,800 & 2.5 \\
\hline young bluegill to largemouth bass & particulate to insect & 7.9 & 1.1 & 7.2 & 1.1 & 6.5 & 2.8 & 2.3 & 1,800 & 1.3 \\
\hline
\end{tabular}


$9.0 \mu \mathrm{g} / \mathrm{L}$ for Seng Creek. Consideration of other food-web exposure scenarios (tables 6 and 7) would illustrate the range of dissolved Se outcomes rather than the single Se concentration illustrated in the schematic for each site. For example, including a more vulnerable species of fish than creek chub could be represented by a TTF of 1.3 , which lowers the outcome for Seng Creek from $14.2 \mu \mathrm{g} / \mathrm{L}$ to 12.2 $\mu \mathrm{g} / \mathrm{L}$. Similarly, use of a fish-tissue guideline of $5 \mu \mathrm{g} / \mathrm{g}$ $(\mathrm{wb} \mathrm{dw}$ ) would further lower the predicted dissolved Se concentrations and require decreases in all observed stream Se concentration to adhere to the translated tissue guideline (figs. 27-28).

Predicted fish Se concentrations based on previous model runs (tables 4 and 5) and observed fish Se concentrations also are presented to help visualize current concentrations in comparison to a guideline of $7.9-\mu \mathrm{g} / \mathrm{g}$. Predicted dissolved Se concentrations for valley-fill ponds (hypothetical scenarios) and the Upper Mud River Reservoir are shown for context, but note (tables 8 and 9) that food webs other than those for aquatic insects may dominate in these impoundment settings (figs. 8 and 11; tables 4 and 5).

Included on the schematics (figs. 25-28) are data for locational and hydrologic variables that may affect the magnitude of $\mathrm{K}_{\mathrm{d}}$ : area of stream basin; stream gradient and order; velocity; median discharge; and variability of Se concentration within the stream over time (see also figs. $7 A, B, 21)$. For example:

- range of estimated stream basin areas is $5.6-87 \mathrm{mi}^{2}$;

- range of estimated stream gradients is from high [188 ft/ mi (3.6-percent slope)] to low [14 ft/mi (0.27-percent slope)];

- range of estimated stream order is second order to fourth order; and

- range of estimated median discharge is $2.1-23.8 \mathrm{ft}^{3} / \mathrm{s}$ (see additional information in "Physical Habitat and Stream Attribute" section)

The graphical insert on figure 25 shows several time periods (July 2002-May 2003; July, August, and October 2011) of sampling for dissolved Se for Seng Creek at different stream locations (mile 0, 2.5, and 3.6) (WVDEP, 2006). The insert shows that Se concentrations increased during a spring flush at mile 3.6 during March and April 2003. Peaks in late summer and early fall (July, August, and October 2011 at mile 3.6) also occurred perhaps as a function of less water in the system.

In summary, figures $25-28$ provide examples of the type of analysis of landscape variables that can link to model parameters for streams. However, a finer scale for these types of variables, along with additional sampling for derivation of $\mathrm{K}_{\mathrm{d}} \mathrm{s}$ than presented here, would help narrow uncertainty and categorize modeling sites within a basin or watershed.

\section{Additional Modeling Components and Specificity}

\section{Fish Species: Abundance, Richness, and Deformity}

Fish community data are organized by (1) richness and abundance for each sampling site and date (table 12); (2) abundance for each fish species (table 13); (3) species and abundance for each sampling site and date (table 14); and (4) darter species richness and abundance (table 15). Richness data were available for 9 sites in fall 2010 and 10 sites in spring 2011, with cross-seasonal comparison possible for 5 sampled sites (table 12). Sampling for Se and general water-quality parameters were not matched to collection of fish community data, but time series for Se and sulfate concentrations, conductivity, and temperature measured at other times during 2010 and 2011 are shown in figure 21 for context. Stream order (table 12) also is a variable to consider when addressing species richness, because fish diversity usually increases with increasing stream order. The generalized range of stream order for sites sampled here is second order to fourth order, with six third-order streams. End-member streams are: Ash Fork and Clear Fork upper, second order; and White Oak Creek, Mud River, Cabin Creek, Beech Creek, and Birch River, fourth order. Stream and physical habitat quality attributes that also help conceptualize and define site conditions available for fish are discussed in the next section.

Comparisons of richness across sites in SeptemberOctober 2010 showed that left fork Mud River, Clear Fork lower, and Mud River lower yielded the most species (that is, 14-21) (table 12). Sycamore and Ash Fork yielded the fewest species (that is, 5-6). For the Mud River upper and lower sites, species richness increased going downstream, with the upper site yielding 9 species and the lower site 14 species. Similarly, Clear Fork upper yielded 10 species, with the lower site yielding 17 species. Twentymile Creek upper and lower had similar numbers of species ( 9 and 10, respectively).

For the five sites sampled in common during fall (September-October 2010) and spring (April-May 2011), seasonal comparison showed a similar number of species, except for Twentymile Creek upper, which yielded nine species in fall but five species in spring (table 12). For sites sampled only during April-May 2011, species richness was: White Oak Creek, 11; Seng Creek, 2; Cabin Creek, 2; Beech Creek, 10; and the Birch River, 6 (table 12).

Abundance data are available for six sites during September-October 2010 (table 13). At the times and places sampled, abundance was highest at left fork Mud River (338 fish observed), with Sycamore Creek the second highest (151 fish observed). For the four other sites, the 
$K_{d} s$ for June 2011

Seng Creek - basin 5.6 sq mi* (high gradient)
Site-specific base-case scenarios (see table 8)

Predicted dissolved Se concentrations

Food web: suspended particulate material to aquatic insect to creek chub Fish tissue guideline: $7.9 \mu \mathrm{g} / \mathbf{g} \mathbf{w b} \mathrm{dw}$

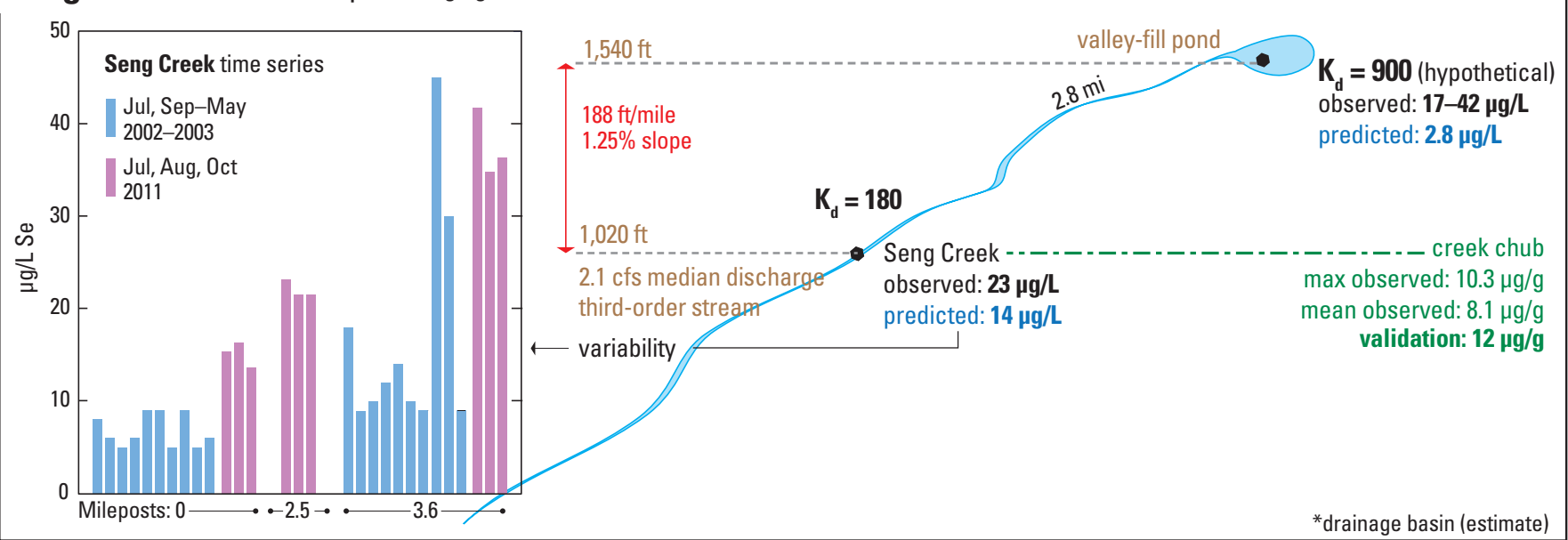

Cabin Creek - basin 49.8 sq mi* (moderate gradient)

\begin{tabular}{|c|c|c|}
\hline $\begin{array}{l}100 \mathrm{ft} / \mathrm{mile} \\
1.9 \% \text { slope } \\
\text { estimated }\end{array}$ & $\begin{array}{ll}\mathbf{K}_{\mathrm{d}}=\mathbf{5 0 5} & \begin{array}{l}\text { Cabin Creek } \\
\text { observed: } 6.2 \mu \mathrm{mi} / \mathrm{L} \\
\text { Leewood }\end{array} \text { predicted: } 5.1 \mu \mathrm{g} / \mathrm{L}\end{array}$ & 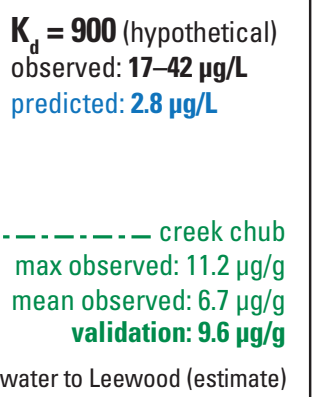 \\
\hline
\end{tabular}

\section{$K_{d}$ s for June 2008}

Upper Mud River - basin 44.5 sq mi* (low gradient)

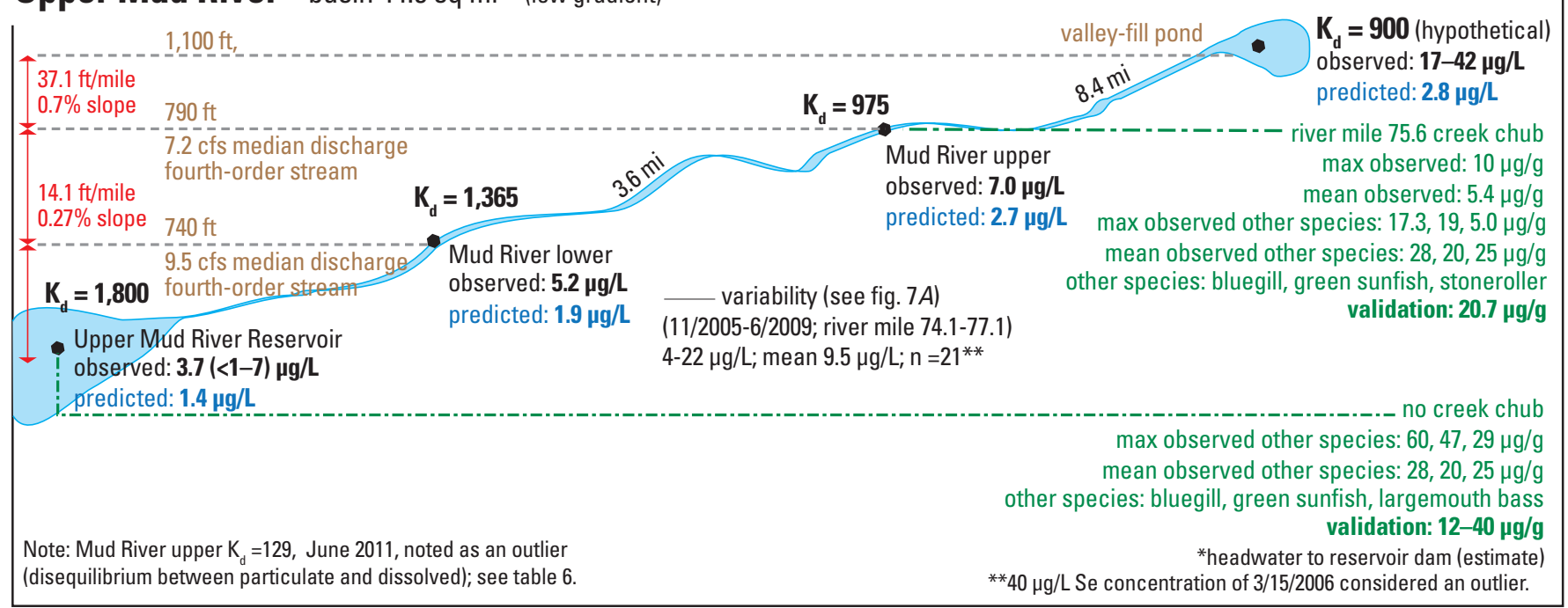

Figure 25. Schematic representation of model application for streams (Seng Creek, Cabin Creek, Upper Mud River and Reservoir) illustrating site-specific $\mathrm{K}_{\mathrm{d}} \mathrm{s}$ (June 2011 and June 2008) and predicted dissolved Se concentrations derived by using a fish-tissue guideline of $7.9 \mu \mathrm{g} / \mathrm{g}(\mathrm{wb} \mathrm{dw})$ for the base-case scenario of suspended particulate material to aquatic insect to creek chub. Inset time-series bar graph shows water-column Se concentrations at Seng Creek. 


\section{Selenium in Ecosystems within the Mountaintop Coal Mining and Valley-Fill Region of Southern West Virginia}

Table 9. Site-specific exposure scenarios: regulatory fish-tissue Se target of $7.9 \mu \mathrm{g} / \mathrm{g}(\mathrm{wb}, \mathrm{dw}$ ) to dissolved Se concentrations specific to February-March 2011 hydrologic conditions.

[TTF, trophic transfer factor; $\mu \mathrm{g} / \mathrm{L}$, micrograms per liter; $\mu \mathrm{g} / \mathrm{g} \mathrm{dw}$, micrograms per gram dry weight; wb, whole body; *not regulated as "waters of the state"; NA, not available; predicted values in blue]

\begin{tabular}{|c|c|c|c|c|c|c|c|c|c|c|}
\hline Fish species & Food web & $\begin{array}{c}\text { Fish } \\
\text { target } \\
\text { Se, in } \\
\mu g / g \\
w b d w\end{array}$ & $\mathrm{TTF}_{\substack{\text { predator } \\
\text { fish }}}$ & $\begin{array}{l}\text { Predicted } \\
\text { forage } \\
\text { fish Se, } \\
\text { in } \mu g / g \\
\text { wb dw }\end{array}$ & $\underbrace{}_{\substack{\text { fish } \\
\text { forage }}}$ & $\begin{array}{l}\text { Predicted } \\
\text { invertebrate } \\
\text { Se, in } \\
\mu \mathrm{g} / \mathrm{g} \mathrm{dw}\end{array}$ & $\prod_{\text {invertebrate }}$ & $\begin{array}{l}\text { Predicted } \\
\text { particulate } \\
\text { material } \\
\text { Se, in } \mu \mathrm{g} / \mathrm{g} \\
\quad \mathrm{dw}\end{array}$ & $\begin{array}{l}\text { Site- } \\
\text { specific } \\
K_{d}\end{array}$ & $\begin{array}{c}\text { Predicted } \\
\text { dissolved } \\
\text { Se, in } \\
\mu \mathrm{g} / \mathrm{L}\end{array}$ \\
\hline \multicolumn{11}{|c|}{ February-March valley-fill pond (hypothetical)* } \\
\hline creek chub & particulate to insect & 7.9 & 1.1 & NA & NA & 7.2 & 2.8 & 2.6 & 600 & 4.3 \\
\hline creek chub & particulate to insect & 7.9 & 0.7 & NA & NA & 11.3 & 2.8 & 4.0 & 600 & 6.7 \\
\hline green sunfish or bluegill sunfish & particulate to insect & 7.9 & 1.3 & NA & NA & 6.1 & 2.8 & 2.2 & 600 & 3.7 \\
\hline green sunfish & particulate to clam & 7.9 & 1.1 & NA & NA & 7.2 & 4.0 & 1.8 & 600 & 3.0 \\
\hline bluntnose minnow & particulate to chironomid & 7.9 & 1.1 & NA & NA & 7.2 & 4.0 & 1.8 & 600 & 3.0 \\
\hline young creek chub to adult fish & particulate to insect & 7.9 & 1.1 & 7.2 & 1.1 & 6.5 & 2.8 & 2.3 & 600 & 3.9 \\
\hline \multicolumn{11}{|c|}{ February-March stream 2011 (Mud River upper and lower) } \\
\hline stoneroller & particulate & 7.9 & NA & NA & 1.1 & NA & NA & 7.2 & 310 & 23.2 \\
\hline young stoneroller to adult rock bass & particulate & 7.9 & 1.1 & 7.2 & 1.1 & NA & NA & 6.5 & 310 & 21.1 \\
\hline creek chub & particulate to insect & 7.9 & 1.1 & NA & NA & 7.2 & 2.8 & 2.6 & 310 & 8.3 \\
\hline creek chub & particulate to insect & 7.9 & 0.7 & NA & NA & 11.3 & 2.8 & 4.0 & 310 & 13.0 \\
\hline green sunfish or bluegill sunfish & particulate to insect & 7.9 & 1.3 & NA & NA & 6.1 & 2.8 & 2.2 & 310 & 7.1 \\
\hline white sucker & particulate to clam & 7.9 & 1.1 & NA & NA & 7.2 & 4.0 & 1.8 & 310 & 5.8 \\
\hline rainbow darter & particulate to chironomid & 7.9 & 1.1 & NA & NA & 7.2 & 4.0 & 1.8 & 310 & 5.8 \\
\hline young creek chub to adult rock bass & particulate to insect & 7.9 & 1.1 & 7.2 & 1.1 & 6.5 & 2.8 & 2.3 & 310 & 7.5 \\
\hline \multicolumn{11}{|c|}{ February-March stream 2011 (Twentymile Creek upper) } \\
\hline stoneroller & particulate & 7.9 & NA & NA & 1.1 & NA & NA & 7.2 & 505 & 14.2 \\
\hline stoneroller to rock bass & particulate & 7.9 & 1.1 & 7.2 & 1.1 & NA & NA & 6.5 & 505 & 12.9 \\
\hline creek chub & particulate to insect & 7.9 & 1.1 & NA & NA & 7.2 & 2.8 & 2.6 & 505 & 5.1 \\
\hline creek chub & particulate to insect & 7.9 & 0.7 & NA & NA & 11.3 & 2.8 & 4.0 & 505 & 8.0 \\
\hline green sunfish or bluegill sunfish & particulate to insect & 7.9 & 1.3 & NA & NA & 6.1 & 2.8 & 2.2 & 505 & 4.4 \\
\hline white sucker & particulate to clam & 7.9 & 1.1 & NA & NA & 7.2 & 4.0 & 1.8 & 505 & 3.6 \\
\hline rainbow darter & particulate to chironomid & 7.9 & 1.1 & NA & NA & 7.2 & 4.0 & 1.8 & 505 & 3.6 \\
\hline young creek chub to adult rock bass & particulate to insect & 7.9 & 1.1 & 7.2 & 1.1 & 6.5 & 2.8 & 2.3 & 505 & 4.6 \\
\hline \multicolumn{11}{|c|}{ February-March stream 2011 (Twentymile Creek lower) } \\
\hline stoneroller & particulate & 7.9 & NA & NA & 1.1 & NA & NA & 7.2 & 793 & 9.1 \\
\hline stoneroller to rock bass & particulate & 7.9 & 1.1 & 7.2 & 1.1 & NA & NA & 6.5 & 793 & 8.2 \\
\hline creek chub & particulate to insect & 7.9 & 1.1 & NA & NA & 7.2 & 2.8 & 2.6 & 793 & 3.2 \\
\hline creek chub & particulate to insect & 7.9 & 0.7 & NA & NA & 11.3 & 2.8 & 4.0 & 793 & 5.1 \\
\hline green sunfish or bluegill sunfish & particulate to insect & 7.9 & 1.3 & NA & NA & 6.1 & 2.8 & 2.2 & 793 & 2.8 \\
\hline white sucker & particulate to clam & 7.9 & 1.1 & NA & NA & 7.2 & 4.0 & 1.8 & 793 & 2.3 \\
\hline rainbow darter & particulate to chironomid & 7.9 & 1.1 & NA & NA & 7.2 & 4.0 & 1.8 & 793 & 2.3 \\
\hline young creek chub to adult rock bass & particulate to insect & 7.9 & 1.1 & 7.2 & 1.1 & 6.5 & 2.8 & 2.3 & 793 & 2.9 \\
\hline \multicolumn{11}{|c|}{ February-March stream 2011 (Clear Fork lower) } \\
\hline stoneroller & particulate & 7.9 & NA & NA & 1.1 & NA & NA & 7.2 & 867 & 8.3 \\
\hline stoneroller to rock bass & particulate & 7.9 & 1.1 & 7.2 & 1.1 & NA & NA & 6.5 & 867 & 7.5 \\
\hline creek chub & particulate to insect & 7.9 & 1.1 & NA & NA & 7.2 & 2.8 & 2.6 & 867 & 3.0 \\
\hline creek chub & particulate to insect & 7.9 & 0.7 & NA & NA & 11.3 & 2.8 & 4.0 & 867 & 4.6 \\
\hline green sunfish or bluegill sunfish & particulate to insect & 7.9 & 1.3 & NA & NA & 6.1 & 2.8 & 2.2 & 867 & 2.5 \\
\hline white sucker & particulate to clam & 7.9 & 1.1 & NA & NA & 7.2 & 4.0 & 1.8 & 867 & 2.1 \\
\hline rainbow darter & particulate to chironomid & 7.9 & 1.1 & NA & NA & 7.2 & 4.0 & 1.8 & 867 & 2.1 \\
\hline young creek chub to adult rock bass & particulate to insect & 7.9 & 1.1 & 7.2 & 1.1 & 6.5 & 2.8 & 2.3 & 867 & 2.7 \\
\hline
\end{tabular}




\section{$K_{d} s$ for February 2011}

Site-specific base-case scenario (see table 9)

Predicted dissolved Se concentrations

Clear Fork - basin 62.8 sq mi* (moderate to low gradient)

Food web: suspended particulate material to aquatic insect to creek chub Fish tissue guideline: $7.9 \boldsymbol{\mu g} / \mathbf{g} \mathbf{~ w b ~ d w}$

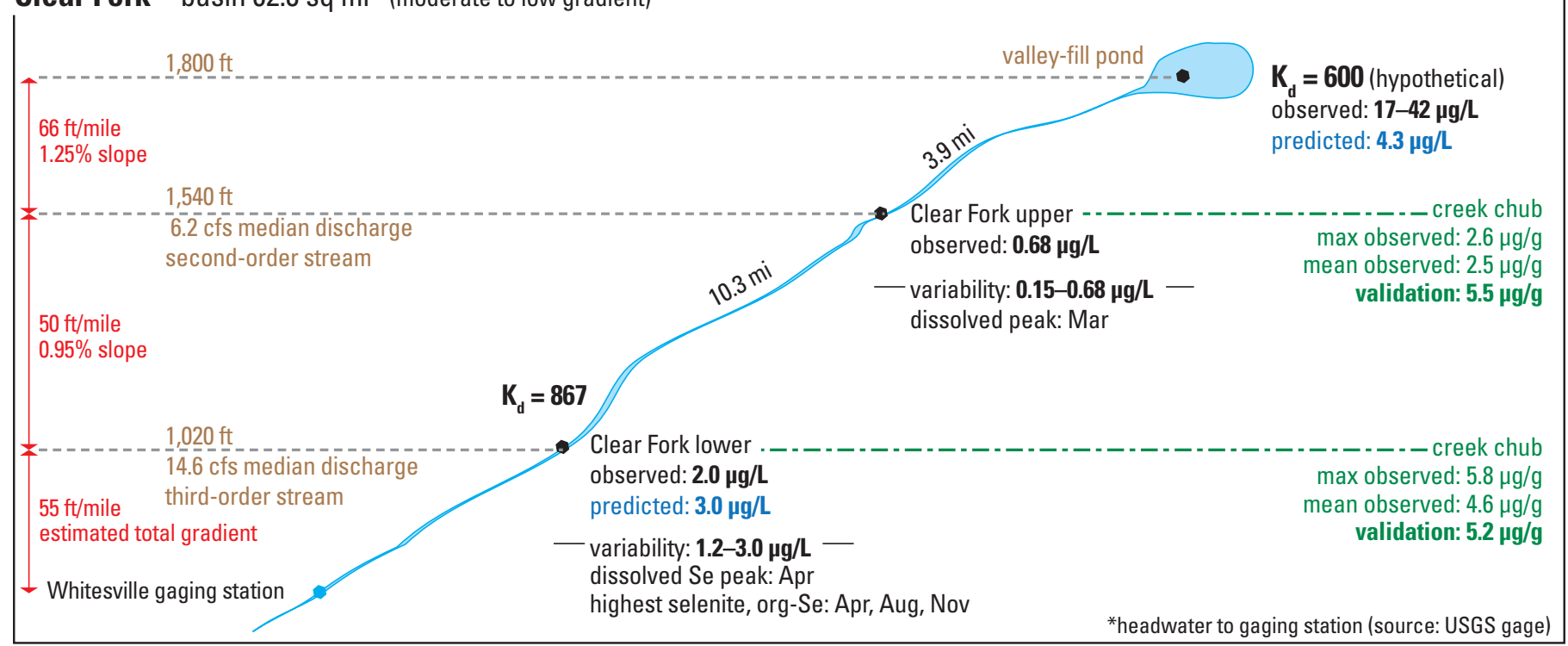

Twentymile Creek - basin 86.6 sq mi* (moderate to low gradient)

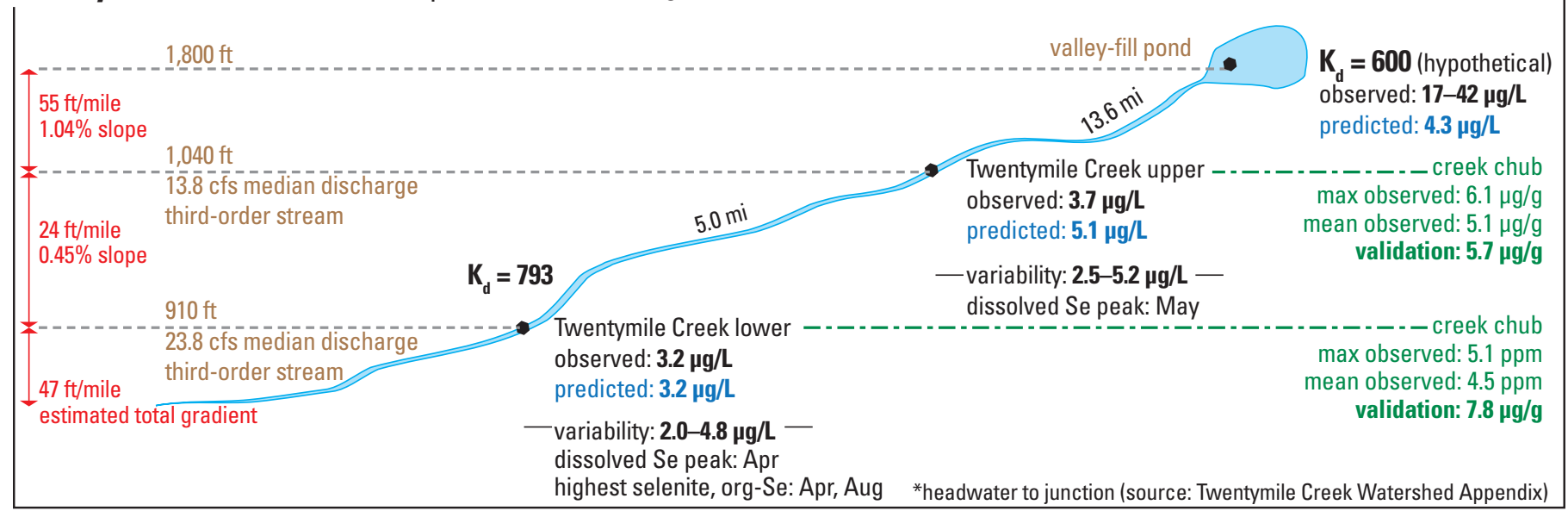

Upper Mud River - basin 44.5 sq mi* (low gradient)

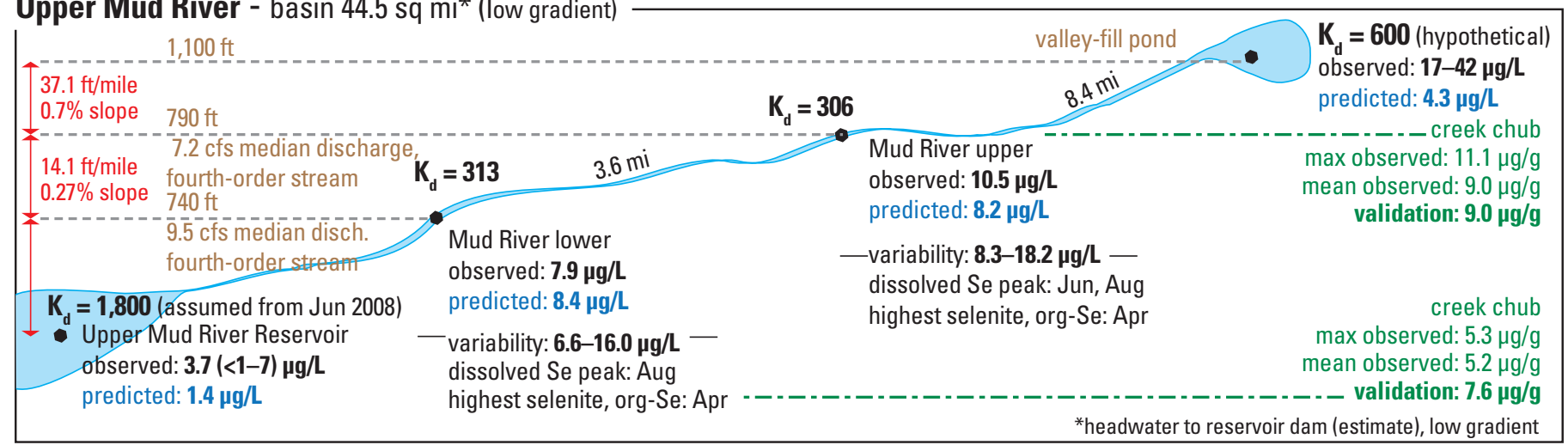

Figure 26. Schematic representation of model application for streams (Clear Fork, Twentymile Creek, Mud River upper) illustrating sitespecific $K_{d} s$ (February 2011) and predicted dissolved Se concentrations derived by using a fish-tissue guideline of $7.9 \mu \mathrm{g} / \mathrm{g}(\mathrm{wb} \mathrm{dw})$ for the base-case scenario of suspended particulate material to aquatic insect to creek chub. 
Table 10. Site-specific exposure scenarios: regulatory fish-tissue Se target of $5.0 \mu \mathrm{g} / \mathrm{g}$ ( $w b, \mathrm{dw}$ ) to dissolved Se concentrations specific to June 2008 and June 2011 hydrologic conditions.

[TTF, trophic transfer factor; $\mu \mathrm{g} / \mathrm{L}$, micrograms per liter; $\mu \mathrm{g} / \mathrm{g}$ dw, micrograms per gram dry weight; wb, whole body; *not regulated as "waters of the state"; NA, not available; predicted values in blue]

\begin{tabular}{|c|c|c|c|c|c|c|c|c|c|c|}
\hline Fish species & Food web & $\begin{array}{c}\text { Fish } \\
\text { target } \\
\text { Se, in } \\
\mu \mathrm{g} / \mathrm{g} \text { wb } \\
\mathrm{dw}\end{array}$ & $\boldsymbol{T}_{\substack{\text { predator } \\
\text { fish }}}$ & $\begin{array}{c}\text { Predicted } \\
\text { forage fish } \\
\text { Se, in } \mu g / g \\
\text { wb dw }\end{array}$ & $\prod_{\substack{\text { forage } \\
\text { fish }}}$ & $\begin{array}{c}\text { Predicted } \\
\text { invertebrate } \\
\text { Se, in } \mu g / g \\
\text { dw }\end{array}$ & $\prod_{\text {invertebrate }}$ & $\begin{array}{c}\text { Predicted } \\
\text { particulate } \\
\text { material Se, } \\
\text { in } \mu \mathrm{g} / \mathrm{g} \mathrm{dw}\end{array}$ & $\begin{array}{c}\text { Site- } \\
\text { specific } \\
K_{d}\end{array}$ & $\begin{array}{l}\text { Predicted } \\
\text { dissolved } \\
\text { Se, in } \mu \mathrm{g} / \mathrm{L}\end{array}$ \\
\hline \multicolumn{11}{|c|}{ June valley-fill pond (hypothetical)* } \\
\hline creek chub & particulate to insect & 5.0 & 1.1 & NA & NA & 4.5 & 2.8 & 1.6 & 900 & 1.8 \\
\hline creek chub & particulate to insect & 5.0 & 0.7 & NA & NA & 7.1 & 2.8 & 2.6 & 900 & 2.8 \\
\hline green sunfish or bluegill sunfish & particulate to insect & 5.0 & 1.3 & NA & NA & 3.8 & 2.8 & 1.4 & 900 & 1.5 \\
\hline green sunfish & particulate to clam & 5.0 & 1.1 & NA & NA & 4.5 & 4.0 & 1.1 & 900 & 1.3 \\
\hline rainbow darter & particulate to chironomid & 5.0 & 1.1 & NA & NA & 4.5 & 4.0 & 1.1 & 900 & 1.3 \\
\hline young creek chub to adult fish & particulate to insect & 5.0 & 1.1 & 4.5 & 1.1 & 4.1 & 2.8 & 1.5 & 900 & 1.6 \\
\hline \multicolumn{11}{|c|}{ June stream 2011 (Seng Creek) } \\
\hline stoneroller & particulate & 5.0 & NA & NA & 1.1 & NA & NA & 4.5 & 180 & 25.3 \\
\hline stoneroller to adult rock bass & particulate & 5.0 & 1.1 & 4.5 & 1.1 & NA & NA & 4.1 & 180 & 23.0 \\
\hline creek chub & particulate to insect & 5.0 & 1.1 & NA & NA & 4.5 & 2.8 & 1.6 & 180 & 9.0 \\
\hline creek chub & particulate to insect & 5.0 & 0.7 & NA & NA & 7.1 & 2.8 & 2.6 & 180 & 14.2 \\
\hline green sunfish or bluegill sunfish & particulate to insect & 5.0 & 1.3 & NA & NA & 3.8 & 2.8 & 1.4 & 180 & 7.8 \\
\hline white sucker & particulate to clam & 5.0 & 1.1 & NA & NA & 4.5 & 4.0 & 1.1 & 180 & 6.3 \\
\hline rainbow darter & particulate to chironomid & 5.0 & 1.1 & NA & NA & 4.5 & 4.0 & 1.1 & 180 & 6.3 \\
\hline young creek chub to adult rock bass & particulate to insect & 5.0 & 1.1 & 4.5 & 1.1 & 4.1 & 2.8 & 1.5 & 180 & 8.2 \\
\hline \multicolumn{11}{|c|}{ June stream 2011 (Cabin Creek) } \\
\hline stoneroller & particulate & 5.0 & NA & NA & 1.1 & NA & NA & 4.5 & 505 & 9.0 \\
\hline stoneroller to adult rock bass & particulate & 5.0 & 1.1 & 4.5 & 1.1 & NA & NA & 4.1 & 505 & 8.2 \\
\hline creek chub & particulate to insect & 5.0 & 1.1 & NA & NA & 4.5 & 2.8 & 1.6 & 505 & 3.2 \\
\hline creek chub & particulate to insect & 5.0 & 0.7 & NA & NA & 7.1 & 2.8 & 2.6 & 505 & 5.1 \\
\hline green sunfish or bluegill sunfish & particulate to insect & 5.0 & 1.3 & NA & NA & 3.8 & 2.8 & 1.4 & 505 & 2.8 \\
\hline white sucker & particulate to clam & 5.0 & 1.1 & NA & NA & 4.5 & 4.0 & 1.1 & 505 & 2.3 \\
\hline rainbow darter & particulate to chironomid & 5.0 & 1.1 & NA & NA & 4.5 & 4.0 & 1.1 & 505 & 2.3 \\
\hline young creek chub to adult rock bass & particulate to insect & 5.0 & 1.1 & 4.5 & 1.1 & 4.1 & 2.8 & 1.5 & 505 & 2.9 \\
\hline \multicolumn{11}{|c|}{ June stream 2008 (Mud River upper) } \\
\hline stoneroller & particulate & 5.0 & NA & NA & 1.1 & NA & NA & 4.5 & 957 & 4.7 \\
\hline stoneroller to adult rock bass & particulate & 5.0 & 1.1 & 4.5 & 1.1 & NA & NA & 4.1 & 957 & 4.3 \\
\hline creek chub & particulate to insect & 5.0 & 1.1 & NA & NA & 4.5 & 2.8 & 1.6 & 957 & 1.7 \\
\hline creek chub & particulate to insect & 5.0 & 0.7 & NA & NA & 7.1 & 2.8 & 2.6 & 957 & 2.7 \\
\hline green sunfish or bluegill sunfish & particulate to insect & 5.0 & 1.3 & NA & NA & 3.8 & 2.8 & 1.4 & 957 & 1.5 \\
\hline white sucker & particulate to clam & 5.0 & 1.1 & NA & NA & 4.5 & 4.0 & 1.1 & 957 & 1.2 \\
\hline rainbow darter & particulate to chironomid & 5.0 & 1.1 & NA & NA & 4.5 & 4.0 & 1.1 & 957 & 1.2 \\
\hline young creek chub to adult rock bass & particulate to insect & 5.0 & 1.1 & 4.5 & 1.1 & 4.1 & 2.8 & 1.5 & 957 & 1.5 \\
\hline \multicolumn{11}{|c|}{ June stream 2008 (Mud River lower) } \\
\hline stoneroller & particulate & 5.0 & NA & NA & 1.1 & NA & NA & 4.5 & 1,365 & 3.3 \\
\hline stoneroller to adult rock bass & particulate & 5.0 & 1.1 & 4.5 & 1.1 & NA & NA & 4.1 & 1,365 & 3.0 \\
\hline creek chub & particulate to insect & 5.0 & 1.1 & NA & NA & 4.5 & 2.8 & 1.6 & 1,365 & 1.2 \\
\hline creek chub & particulate to insect & 5.0 & 0.7 & NA & NA & 7.1 & 2.8 & 2.6 & 1,365 & 1.9 \\
\hline green sunfish or bluegill sunfish & particulate to insect & 5.0 & 1.3 & NA & NA & 3.8 & 2.8 & 1.4 & 1,365 & 1.0 \\
\hline white sucker & particulate to clam & 5.0 & 1.1 & NA & NA & 4.5 & 4.0 & 1.1 & 1,365 & 0.8 \\
\hline rainbow darter & particulate to chironomid & 5.0 & 1.1 & NA & NA & 4.5 & 4.0 & 1.1 & 1,365 & 0.8 \\
\hline young creek chub to adult rock bass & particulate to insect & 5.0 & 1.1 & 4.5 & 1.1 & 4.1 & 2.8 & 1.5 & 1,365 & 1.1 \\
\hline \multicolumn{11}{|c|}{ June reservoir 2008 (Upper Mud River Reservoir) } \\
\hline bluegill or green sunfish & particulate to insect & 5.0 & 1.1 & NA & NA & 4.5 & 2.8 & 1.6 & 1,800 & 0.9 \\
\hline bluegill or green sunfish & particulate to insect & 5.0 & 1.3 & NA & NA & 3.8 & 2.8 & 1.4 & 1.800 & 0.8 \\
\hline $\begin{array}{l}\text { redear sunfish or pumpkinseed } \\
\text { sunfish }\end{array}$ & particulate to snail & 5.0 & 1.1 & NA & NA & 4.5 & 5.5 & 0.8 & 1,800 & 0.5 \\
\hline channel catfish or common carp & particulate to clam or snail & 5.0 & 1.1 & NA & NA & 4.5 & 4.0 & 1.1 & 1,800 & 0.6 \\
\hline largemouth bass & particulate to crayfish & 5.0 & 1.1 & NA & NA & 4.5 & 1.6 & 2.8 & 1,800 & 1.6 \\
\hline young bluegill to largemouth bass & particulate to insect & 5.0 & 1.1 & 4.5 & 1.1 & 4.1 & 2.8 & 1.5 & 1,800 & 0.8 \\
\hline
\end{tabular}


$K_{d}$ s for June 2011

Seng Creek - basin 5.6 sq mi* (high gradient)
Site-specific base-case scenarios (see table 10)

Predicted dissolved Se concentrations

Food web: suspended particulate material to aquatic insect to creek chub Fish tissue guideline: $\mathbf{5 . 0} \boldsymbol{\mu g} / \mathbf{g} \mathbf{~ w b ~ d w}$

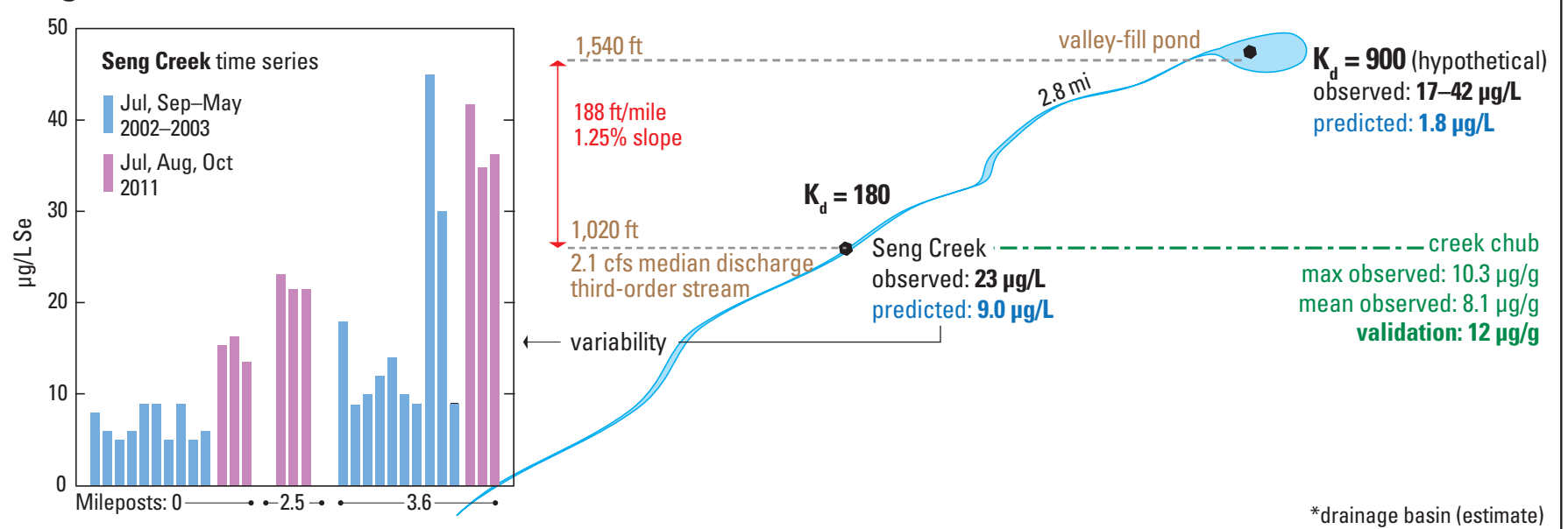

Cabin Creek - basin 49.8 sq mi* (moderate gradient)

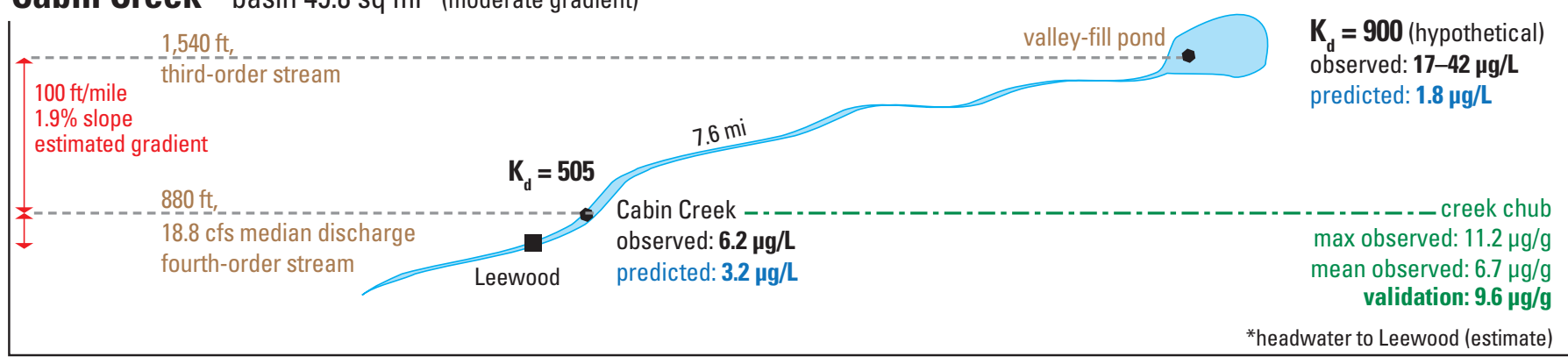

\section{$K_{d} s$ for June 2008}

Upper Mud River - basin 44.5 sq mi* (low gradient)

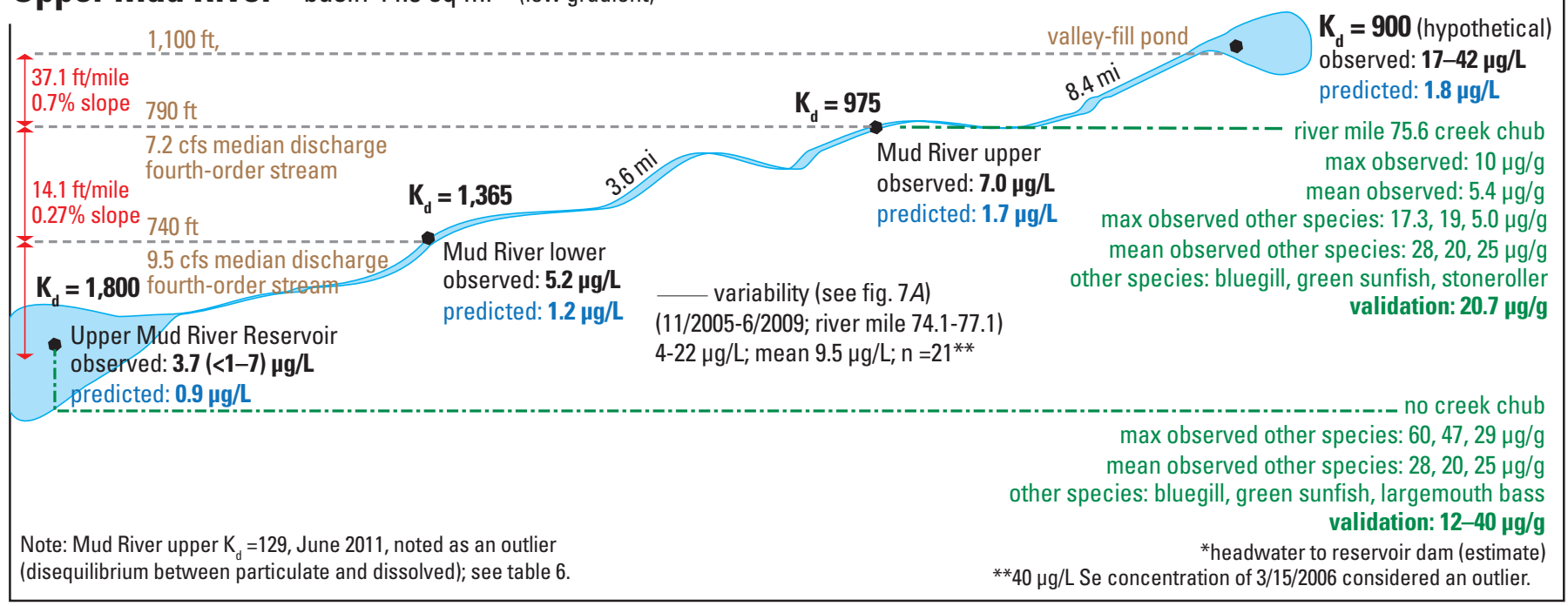

Figure 27. Schematic representation of model application for streams (Seng Creek, Cabin Creek, Upper Mud River and Reservoir) illustrating site-specific $\mathrm{K}_{\mathrm{d}} \mathrm{s}$ (June 2011 and June 2008) and predicted dissolved Se concentrations derived by using a fish-tissue guideline of $5.0 \mu \mathrm{g} / \mathrm{g}(\mathrm{wb} \mathrm{dw})$ for the base-case scenario of suspended particulate material to aquatic insect to creek chub. Inset timeseries bar graph shows water-column Se concentrations at Seng Creek. 
Table 11. Site-specific exposure scenarios: regulatory fish-tissue Se target of $5.0 \mu \mathrm{g} / \mathrm{g}(\mathrm{wb}, \mathrm{dw})$ to dissolved Se concentrations specific to February-March 2011 hydrologic conditions.

[TTF, trophic transfer factor; $\mu \mathrm{g} / \mathrm{L}$, micrograms per liter; $\mu \mathrm{g} / \mathrm{g} \mathrm{dw}$, micrograms per gram dry weight; wb, whole body; *not regulated as "waters of the state"; NA, not available; predicted values in blue]

\begin{tabular}{|c|c|c|c|c|c|c|c|c|c|c|}
\hline Fish species & Food web & $\begin{array}{c}\text { Fish target } \\
\text { Se } \mu g / g \\
w b d w\end{array}$ & $\prod_{\substack{\text { predator } \\
\text { fish }}}$ & $\begin{array}{c}\text { Predicted } \\
\text { forage fish } \\
\text { Se } \mu g / g \text { wb } \\
\text { dw }\end{array}$ & $\underset{\substack{\text { forage } \\
\text { fish }}}{\mathrm{T}_{\text {f }}}$ & $\begin{array}{l}\text { Predicted } \\
\text { invertebrate } \\
\text { Se } \mu \mathrm{g} / \mathrm{g} \mathrm{dw}\end{array}$ & $\prod_{\text {invertebrate }}$ & $\begin{array}{c}\text { Predicted } \\
\text { particulate } \\
\text { material Se } \\
\mu \mathrm{g} / \mathrm{g} \mathrm{dw} \\
\end{array}$ & $\begin{array}{c}\text { Site- } \\
\text { specific } \\
K_{d}\end{array}$ & $\begin{array}{c}\text { Predicted } \\
\text { dissolved } \\
\text { Se } \mu \mathrm{g} / \mathrm{L}\end{array}$ \\
\hline \multicolumn{11}{|c|}{ February-March valley-fill pond (hypothetical)* } \\
\hline creek chub & particulate to insect & 5.0 & 1.1 & NA & NA & 4.5 & 2.8 & 1.6 & 600 & 2.7 \\
\hline creek chub & particulate to insect & 5.0 & 0.7 & NA & NA & 7.1 & 2.8 & 2.6 & 600 & 4.3 \\
\hline $\begin{array}{l}\text { green sunfish or } \\
\text { bluegill sunfish }\end{array}$ & particulate to insect & 5.0 & 1.3 & NA & NA & 3.8 & 2.8 & 1.4 & 600 & 2.3 \\
\hline green sunfish & particulate to clam & 5.0 & 1.1 & NA & NA & 4.5 & 4.0 & 1.1 & 600 & 1.9 \\
\hline rainbow darter & particulate to chironomid & 5.0 & 1.1 & NA & NA & 4.5 & 4.0 & 1.1 & 600 & 1.9 \\
\hline $\begin{array}{l}\text { young creek chub } \\
\text { to adult fish }\end{array}$ & particulate to insect & 5.0 & 1.1 & 4.5 & 1.1 & 4.1 & 2.8 & 1.5 & 600 & 2.5 \\
\hline \multicolumn{11}{|c|}{ February-March stream 2011 (Mud River upper and lower) } \\
\hline stoneroller & particulate & 5.0 & NA & NA & 1.1 & NA & NA & 4.5 & 310 & 14.7 \\
\hline $\begin{array}{l}\text { stoneroller to adult } \\
\text { rock bass }\end{array}$ & particulate & 5.0 & 1.1 & 4.5 & 1.1 & NA & NA & 4.1 & 310 & 13.3 \\
\hline creek chub & particulate to insect & 5.0 & 1.1 & NA & NA & 4.5 & 2.8 & 1.6 & 310 & 5.2 \\
\hline creek chub & particulate to insect & 5.0 & 0.7 & NA & NA & 7.1 & 2.8 & 2.6 & 310 & 8.2 \\
\hline $\begin{array}{l}\text { green sunfish or } \\
\text { bluegill sunfish }\end{array}$ & particulate to insect & 5.0 & 1.3 & NA & NA & 3.8 & 2.8 & 1.4 & 310 & 4.5 \\
\hline white sucker & particulate to clam & 5.0 & 1.1 & NA & NA & 4.5 & 4.0 & 1.1 & 310 & 3.7 \\
\hline rainbow darter & particulate to chironomid & 5.0 & 1.1 & NA & NA & 4.5 & 4.0 & 1.1 & 310 & 3.7 \\
\hline $\begin{array}{l}\text { young creek chub } \\
\text { to adult rock bass }\end{array}$ & particulate to insect & 5.0 & 1.1 & 4.5 & 1.1 & 4.1 & 2.8 & 1.5 & 310 & 4.8 \\
\hline \multicolumn{11}{|c|}{ February-March stream 2011 (Twentymile Creek upper) } \\
\hline stoneroller & particulate & 5.0 & NA & NA & 1.1 & NA & NA & 4.5 & 505 & 9.0 \\
\hline $\begin{array}{l}\text { stoneroller to adult } \\
\text { rock bass }\end{array}$ & particulate & 5.0 & 1.1 & 4.5 & 1.1 & NA & NA & 4.1 & 505 & 8.2 \\
\hline creek chub & particulate to insect & 5.0 & 1.1 & NA & NA & 4.5 & 2.8 & 1.6 & 505 & 3.2 \\
\hline creek chub & particulate to insect & 5.0 & 0.7 & NA & NA & 7.1 & 2.8 & 2.6 & 505 & 5.1 \\
\hline $\begin{array}{l}\text { green sunfish or } \\
\text { bluegill sunfish }\end{array}$ & particulate to insect & 5.0 & 1.3 & NA & NA & 3.8 & 2.8 & 1.4 & 505 & 2.8 \\
\hline white sucker & particulate to clam & 5.0 & 1.1 & NA & NA & 4.5 & 4.0 & 1.1 & 505 & 2.3 \\
\hline rainbow darter & particulate to chironomid & 5.0 & 1.1 & NA & NA & 4.5 & 4.0 & 1.1 & 505 & 2.3 \\
\hline $\begin{array}{l}\text { young creek chub } \\
\text { to adult rock bass }\end{array}$ & particulate to insect & 5.0 & 1.1 & 4.5 & 1.1 & 4.1 & 2.8 & 1.5 & 505 & 2.9 \\
\hline \multicolumn{11}{|c|}{ February-March stream 2011 (Twentymile Creek lower) } \\
\hline stoneroller & particulate & 5.0 & NA & NA & 1.1 & NA & NA & 4.5 & 793 & 5.7 \\
\hline $\begin{array}{l}\text { stoneroller to adult } \\
\text { rock bass }\end{array}$ & particulate & 5.0 & 1.1 & 4.5 & 1.1 & NA & NA & 4.1 & 793 & 5.2 \\
\hline creek chub & particulate to insect & 5.0 & 1.1 & NA & NA & 4.5 & 2.8 & 1.6 & 793 & 2.0 \\
\hline creek chub & particulate to insect & 5.0 & 0.7 & NA & NA & 7.1 & 2.8 & 2.6 & 793 & 3.2 \\
\hline $\begin{array}{l}\text { green sunfish or } \\
\text { bluegill sunfish }\end{array}$ & particulate to insect & 5.0 & 1.3 & NA & NA & 3.8 & 2.8 & 1.4 & 793 & 1.8 \\
\hline white sucker & particulate to clam & 5.0 & 1.1 & NA & NA & 4.5 & 4.0 & 1.1 & 793 & 1.4 \\
\hline rainbow darter & particulate to chironomid & 5.0 & 1.1 & NA & NA & 4.5 & 4.0 & 1.1 & 793 & 1.4 \\
\hline $\begin{array}{l}\text { young creek chub } \\
\text { to adult rock bass }\end{array}$ & particulate to insect & 5.0 & 1.1 & 4.5 & 1.1 & 4.1 & 2.8 & 1.5 & 793 & 1.9 \\
\hline
\end{tabular}


Table 11. Site-specific exposure scenarios: regulatory fish-tissue Se target of $5.0 \mu \mathrm{g} / \mathrm{g}(\mathrm{wb}, \mathrm{dw})$ to dissolved Se concentrations specific to February-March 2011 hydrologic conditions.-Continued

[TTF, trophic transfer factor; $\mu \mathrm{g} / \mathrm{L}$, micrograms per liter; $\mu \mathrm{g} / \mathrm{g}$ dw, micrograms per gram dry weight; wb, whole body; *not regulated as "waters of the state"; NA, not available; predicted values in blue]

\begin{tabular}{|c|c|c|c|c|c|c|c|c|c|c|}
\hline Fish species & Food web & $\begin{array}{l}\text { Fish target } \\
\text { Se } \mu g / g \\
\text { wb dw }\end{array}$ & $\prod_{\substack{\text { predator } \\
\text { fish }}}$ & $\begin{array}{c}\text { Predicted } \\
\text { forage fish } \\
\text { Se } \mu g / g \text { wb } \\
\text { dw }\end{array}$ & $\prod_{\substack{\text { forage } \\
\text { fish }}}$ & $\begin{array}{c}\text { Predicted } \\
\text { invertebrate } \\
\text { Se } \mu g / g \text { dw }\end{array}$ & $\prod_{\text {invertebrate }}$ & $\begin{array}{c}\text { Predicted } \\
\text { particulate } \\
\text { material Se } \\
\mu \mathrm{g} / \mathrm{g} \mathrm{dw}\end{array}$ & $\begin{array}{c}\text { Site- } \\
\text { specific } \\
K_{d}\end{array}$ & $\begin{array}{c}\text { Predicted } \\
\text { dissolved } \\
\text { Se } \mu g / L\end{array}$ \\
\hline \multicolumn{11}{|c|}{ February-March stream 2011 (Clear Fork lower) } \\
\hline stoneroller & particulate & 5.0 & NA & NA & 1.1 & NA & NA & 4.5 & 867 & 5.2 \\
\hline $\begin{array}{l}\text { stoneroller to adult } \\
\text { rock bass }\end{array}$ & particulate & 5.0 & 1.1 & 4.5 & 1.1 & NA & NA & 4.1 & 867 & 4.8 \\
\hline creek chub & particulate to insect & 5.0 & 1.1 & NA & NA & 4.5 & 2.8 & 1.6 & 867 & 1.9 \\
\hline creek chub & particulate to insect & 5.0 & 0.7 & NA & NA & 7.1 & 2.8 & 2.6 & 867 & 2.9 \\
\hline $\begin{array}{l}\text { green sunfish or } \\
\text { bluegill sunfish }\end{array}$ & particulate to insect & 5.0 & 1.3 & NA & NA & 3.8 & 2.8 & 1.4 & 867 & 1.6 \\
\hline white sucker & particulate to clam & 5.0 & 1.1 & NA & NA & 4.5 & 4.0 & 1.1 & 867 & 1.3 \\
\hline rainbow darter & particulate to chironomid & 5.0 & 1.1 & NA & NA & 4.5 & 4.0 & 1.1 & 867 & 1.3 \\
\hline $\begin{array}{l}\text { young creek chub } \\
\text { to adult rock bass }\end{array}$ & particulate to insect & 5.0 & 1.1 & 4.5 & 1.1 & 4.1 & 2.8 & 1.5 & 867 & 1.7 \\
\hline
\end{tabular}

order of abundance was: Mud River lower, Mud River upper, Twentymile Creek upper, and Twentymile Creek lower. The order of abundance for species with greater than 28 individuals was: creek chub, striped shiner, mottled sculpin, green sunfish, central stoneroller, blacknose dace, bluntnose minnow, and northern hog sucker. Shiners and darters were prevalent, but bluegill sunfish were absent during the 2010 survey (tables 13 and 14). As described previously (figs. 9 and 10) bluegill sunfish were collected for Se analysis from the Upper Mud River near mile 75.6 in 2006 and 2007, and they have a continuing presence at the Upper Mud River Reservoir.

Table 14 gives a detailed list of species found at each site. The number of species and species characteristics or traits (for example, table 1) can be used to rank each site in terms of fish community health and diversity (for example, Index of Biotic Integrity) (see, for example, Karr, 1981). This ranking then relates to overall ecosystem composition, structure, and function. A high percentage of (1) fish species such as creek chub and stoneroller that are considered of high tolerance to environmental stress (table 1) (Stauffer and Ferreri, 2002; Short and others, 2008) and (2) fish species such as creek chub that are considered pioneering species (that is, one that is able to colonize a disrupted ecosystem) at a stream site affects the ranking of the biological integrity of an ecosystem (see, for example, Pyron and others, 2004; Walters, 2006).

Darter species richness and abundance (table 15) is given as an example of a benthic insectivore's (table 1) presence in sampled streams. The highest numbers of darter species were found at left fork Mud River (5), Clear Fork lower (3), and Mud River lower (3). Sampling of other sites yielded one or two darter species, except for Ash Fork, Seng Creek, and Cabin Creek, where no darters were present. Darter abundance was the greatest at Sycamore Creek and left fork Mud River. The number and composition of darters also can be used as a metric to rank the biological integrity of a stream, because most darters are considered sensitive to environmental stress (Karr, 1981).

An adult female creek chub with a spinal deformity (lordosis) that is likely to be associated with Se toxicity was found at the Mud River upper site during collection of fish assemblage data in September 2010 (table 14). As stated previously, wb Se concentrations for all fish collected in the 2010-2011 study at the Mud River upper site (mean, 8.1 $\mu \mathrm{g} / \mathrm{g}$; range $5.0-11.1 \mu \mathrm{g} / \mathrm{g}$ ) were equal to or exceeded the toxicity guideline of $5 \mu \mathrm{g} / \mathrm{g}(\mathrm{wb} \mathrm{dw})$ considered here (figs. 11 and 16). The mean wb Se concentration for this site slightly exceeded the upper toxicity guideline of $7.9 \mu \mathrm{g} / \mathrm{g}$ ( $\mathrm{wb} \mathrm{dw}$ ). Fifty-eight percent of all fish at this site exceeded this upper guideline, with the highest Se concentrations measured in spring 2010. Specifically, the wb Se concentration for the deformed adult creek chub of $6.7 \mu \mathrm{g} / \mathrm{g} \mathrm{dw}$ (D.B. Chambers, USGS, written commun., 2013) was not expected to directly reflect the conditions that led to the deformity. It is the analysis of reproductive tissue (ovary) that would give an indication of potential effects to reproduction from Se. For the Mud River upper site in March 2010, ovary Se concentrations ranged from 16.4 to $22.2 \mu \mathrm{g} / \mathrm{g} \mathrm{dw}$, with a mean ovary Se concentration of $18.4 \mu \mathrm{g} / \mathrm{g} \mathrm{dw}$ (table 16; fig. 16). All of these Se concentrations exceeded both of the ovary toxicity guidelines illustrated here $(6.5$ and $11 \mu \mathrm{g} / \mathrm{g} \mathrm{dw})$. For comparison during the same 


\section{$K_{\mathrm{d}} \mathrm{s}$ for February 2011}

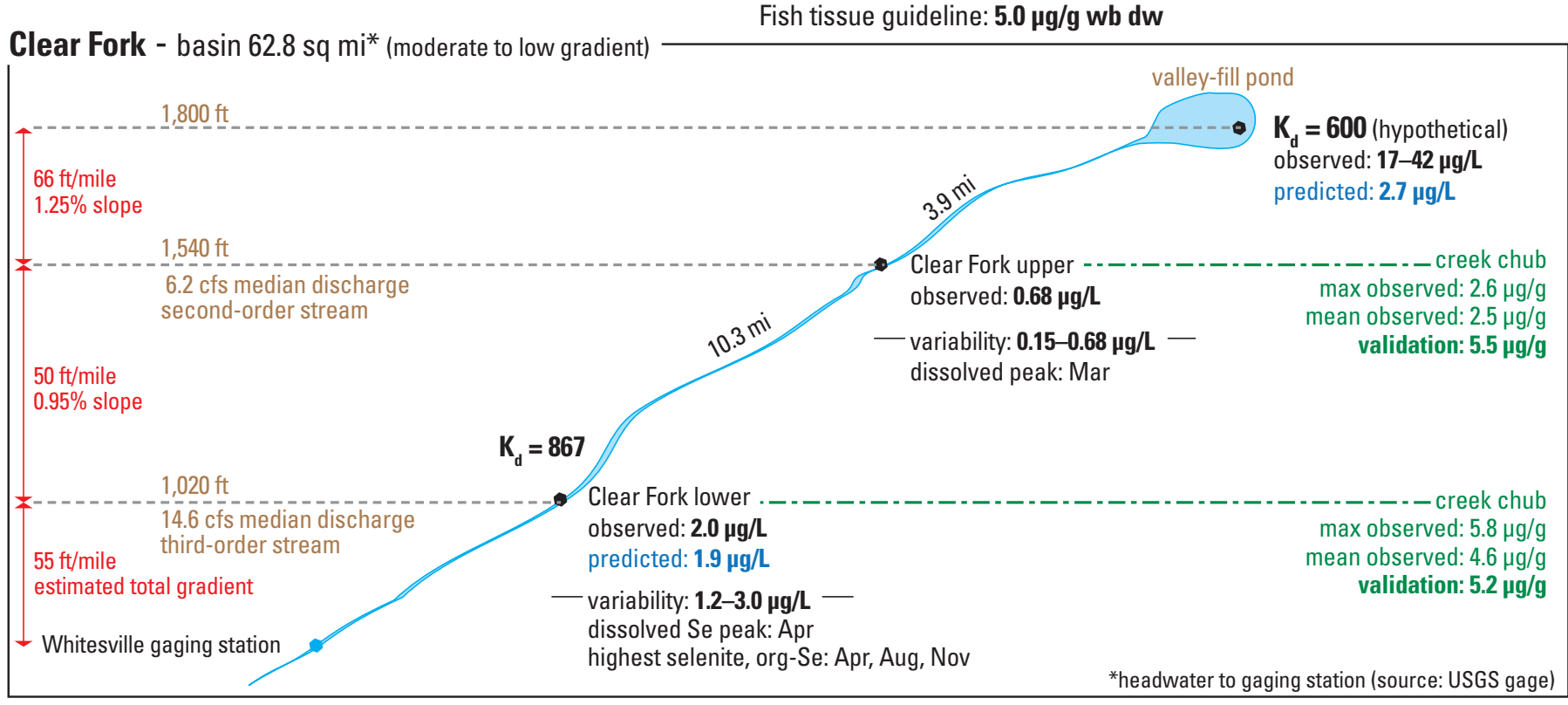

Site-specific base-case scenario (see table 11)

Predicted dissolved Se concentrations

Food web: suspended particulate material to aquatic insect to creek chub Fish tissue guideline: $\mathbf{5 . 0} \boldsymbol{\mu g} / \mathbf{g} \mathbf{w b} \mathbf{d w}$

Twentymile Creek - basin 86.6 sq mi* (moderate to low gradient)

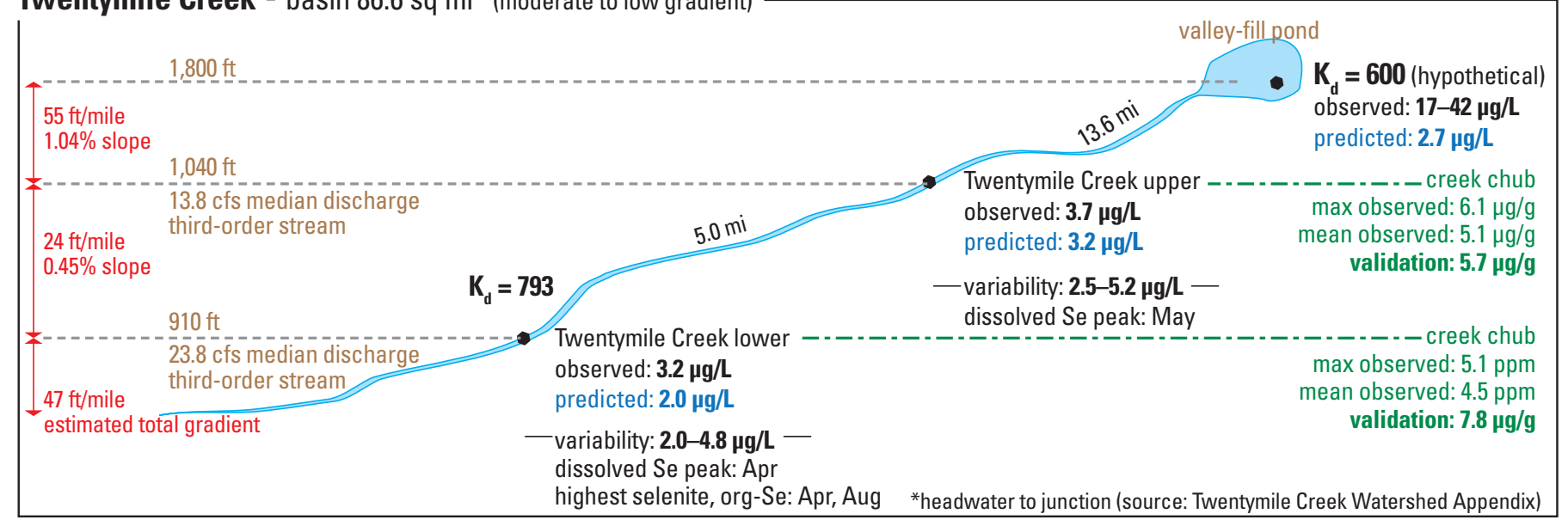

Figure 28. Schematic representation of model application for streams (Clear Fork, Twentymile Creek, Mud River upper) illustrating sitespecific $K_{d} s$ (February 2011) and predicted dissolved Se concentrations derived by using a fish-tissue guideline of $5.0 \mu \mathrm{g} / \mathrm{g}$ wb $\mathrm{dw}$ for the base-case scenario of suspended particulate material to aquatic insect to creek chub. 
Table 12. Fish community data by site including species richness and abundance, with estimated stream order also given.

[Richness, number of species; abundance, total number of individuals]

\begin{tabular}{|c|c|c|c|c|c|c|}
\hline Field site & $\begin{array}{c}\text { Estimated } \\
\text { stream order }\end{array}$ & $\begin{array}{c}2010 \\
\text { sampling }\end{array}$ & Richness & Abundance & 2011 sampling & Richness \\
\hline \multicolumn{7}{|c|}{ Twentymile Creek basin } \\
\hline Ash Fork & 2 & Mar 2010 & 6 & & not sampled & \\
\hline Twentymile Creek lower & 3 & Oct 2010 & 10 & 43 & not sampled & \\
\hline Twentymile Creek upper & 3 & Sep 2010 & 9 & 66 & Apr 2011 & 5 \\
\hline \multicolumn{7}{|c|}{ Clear Fork basin } \\
\hline White Oak Creek & 4 & not sampled & & & Apr 2011 & 11 \\
\hline Seng Creek & 3 & not sampled & & & Apr 2011 & 2 \\
\hline Sycamore Creek & 3 & Oct 2010 & 5 & 151 & Apr 2011 & 5 \\
\hline Clear Fork lower & 3 & Oct 2010 & 17 & & not sampled & \\
\hline Clear Fork upper & 2 & Oct 2010 & 10 & & Apr 2011 & 9 \\
\hline \multicolumn{7}{|c|}{ Upper Mud River basin } \\
\hline left fork Mud River & 3 & Sep 2010 & 21 & 338 & May 2011 & 18 \\
\hline Upton Branch & & not visited & & & & \\
\hline Mud River lower & 4 & Oct 2010 & 14 & 70 & not sampled & \\
\hline Mud River upper & 4 & Sep 2010 & 9 & 68 & May 2011 & 8 \\
\hline \multicolumn{7}{|c|}{ Other basins } \\
\hline Cabin Creek & 4 & not sampled & & & Apr 2011 & 2 \\
\hline Beech Creek & 4 & not sampled & & & Apr 2011 & 10 \\
\hline Birch River & 4 & not sampled & & & Apr 2011 & 6 \\
\hline
\end{tabular}

time period, an ovary Se concentration of $5.8 \mu \mathrm{g} / \mathrm{g}$ dw was measured at the left fork Mud River, and a range of ovary Se concentrations of 5.1-5.8 $\mu \mathrm{g} / \mathrm{g} \mathrm{dw}$ was measured at the Upton Branch. Although numbers of ovary samples are limited, other sampled sites within other basins also had fish with all ovary Se concentrations above or within the range of the two illustrated toxicity guidelines: Twentymile Creek lower and upper; Seng Creek; and Cabin Creek (table 16; figs. 16-19). Further, the maximum ovary Se concentrations for sampled fish at Clear Fork lower and Sycamore Creek were above $10 \mu \mathrm{g} / \mathrm{g}$ dw. Research has shown that ovary Se concentrations in fish are dependent on time of sampling (that is, ripeness of ovaries) and fish species (deBruyn and others, 2008; Osmundson and Skorupa, 2011). The occurrences of adult fish deformities at two main-stem Upper Mud River sites (see also cranial-facial deformities in adult Lepomis sp. hybrids, Lindberg and others, 2011) and the range of elevated ovary Se concentrations seen during this study may widen the scope of hydrologic and ecosystems conditions under which elevated ecological Se risk in fish is realized in this watershed (that is, both river and reservoir).

\section{Temporal Exposure: Dissolved Selenium, Conductivity, Sulfate, and Temperature}

Detailed data for conductivity, temperature, hardness, $\mathrm{pH}$, dissolved oxygen, cations, and anions are compiled in appendix 1. Bernhardt and others, (2012) found an elevated sulfate concentration of $197 \pm 21 \mathrm{mg} / \mathrm{L}$ to be associated with streams draining catchments with mountaintop coal mining in southern West Virginia. Means of conductivity measurements for Ash Fork, Sycamore Creek, Upton Branch, and left fork Mud River showed a range of $43-203 \mu \mathrm{S} / \mathrm{cm}$, with the remaining study sites showing a higher range of $527-1,882 \mu \mathrm{S} / \mathrm{cm}$ (appendix 1).

Figures $21 A-D$ show changes in dissolved Se concentration, conductivity, sulfate concentration, and temperature with time (April 2010 to June 2011). Time series such as these can add a temporal component on which to base modeling. As stated previously, overlaying even a coarse temporal scale, such as through seasonal modeling, can substantially narrow uncertainty in developed exposure scenarios. 
Low temperatures in November through March coincide with time periods of decreasing conductivity and sulfate and Se concentrations (fig. 21). Although data are limited, signs of a flush of dissolved constituents during snowmelt in spring may be similar to that reported previously for cross-valley mining fills (Presser and others, 2004b) (fig. 21A). These factors may affect derivation of $\mathrm{K}_{\mathrm{d}} \mathrm{s}$ using dissolved and suspended-particulate-material $\mathrm{Se}$ concentrations collected during that time period (table 3). For example, $\mathrm{K}_{\mathrm{d}} \mathrm{s}$ based on particulate concentrations during the summer months (that is, August; table 3) may represent a maximum potential for Se transformation and partitioning. Sulfate concentrations and conductivity track together at samples sites, with maxima occurring at four sites in November and at two sites in August. Maxima in dissolved Se concentrations are offset from conductivity and sulfate maxima. Selenium maxima occurred in August for Mud River upper and lower sites and within April to August for Twentymile Creek upper and lower sites and the Clear Fork lower site.

\section{Physical Habitat and Stream Attributes}

Stream attribute and physical habitat quality data were collected during the first year of study (July 6-9, 2010) to determine the range of conditions represented at the initial 10 study sites (figs. 29 and 30). In general, these types of measurements help standardize the position of the stream in the landscape and its interaction with the geology, hydrology, and vegetative structure of the basin (for example, Lazorchak and others, 1998; Barbour and others, 1999; Chambers and Messinger, 2001). In restoration studies, physical habitat components can be mapped under different flow conditions to help define and assess available fish habitat for site-specific species.

Physical habitat quality parameters (fig. 29) included percentages of (1) mesohabitat components (cascade, pool, riffle, run); (2) substrate composition (clay, sand, gravel, cobble, boulder, bedrock); and 3) riparian habitat cover. For example, in July 2010 (1) most streams were primarily runs and pools (for example, Upper Mud River basin), but Sycamore Creek contained abundant riffles and a stream cascade; (2) Clear Fork basin contained cobbles and boulders, whereas the Upper Mud River basin contained a larger proportion of sand substrate (figs. 29A and B). Riparian habitat cover (fig. 29C) can distinguish areas of connectivity or disturbance. The mean riparian habitat cover for nine streams was above 80 percent, with only Clear Fork providing less cover (55 percent).

Steam attributes (thalweg depth, wetted width, and flow velocity) can help define basin hydrology (figs. 30A-C). In July 2010, Ash Fork and Upton Branch were dominated by isolated pools (that is, no measureable flow), with the other streams exhibiting mean flow velocities of $<1.1 \mathrm{ft} / \mathrm{s}$ (fig. 30C). The range was $0.22-1.1 \mathrm{ft} / \mathrm{s}$, with Clear Fork lower measuring the highest. Mean thalweg depth for all flowing streams was less than $0.37 \mathrm{~m}(1.2 \mathrm{ft})$, with Clear Fork lower measuring the highest (fig. 30A). Mean wetted width varied from a low of 3.1 $\mathrm{m}(10.2 \mathrm{ft})$ at left fork Mud River to a high of $10.1 \mathrm{~m}(33.1 \mathrm{ft})$ for Twentymile Creek lower (fig. 30B).
Table 13. Fish abundance by species for all sites and sampling periods. [present $=$ count not recorded]

\begin{tabular}{lclc}
\hline Common name & Abundance & \multicolumn{1}{c}{ Common name } & Abundance \\
\hline Rosyface shiner & 1 & Fantail darter & 21 \\
Whitetail shiner & 1 & Silverjaw minnow & 21 \\
Yellow bullhead & 1 & Least brook lamprey & 24 \\
Golden redhorse & 2 & Northern hog sucker & 29 \\
Smallmouth bass & 2 & Bluntnose minnow & 44 \\
Spotted bass & 2 & Blacknose dace & 48 \\
Greenside darter & 3 & Central stoneroller & 57 \\
Popeye shiner & 3 & Green sunfish & 60 \\
Silver shiner & 4 & Mottled sculpin & 65 \\
Bigmouth chub & 6 & Striped shiner & 68 \\
Blackside darter & 6 & Creek chub & 181 \\
Telescope shiner & 6 & Banded darter & present \\
Logperch darter & 7 & Bigeye chub & present \\
Redfin shiner & 8 & Largemouth bass & present \\
Longear sunfish & 10 & Longnose dace & present \\
Rock bass & 10 & Pumpkinseed sunfish & present \\
Rainbow darter & 13 & River chub & present \\
White sucker & 13 & Sand shiner & present \\
Johnny darter & 20 & Spotfin shiner & present \\
\hline
\end{tabular}

These three types of stream measurements can be used in combination to approximate discharge. If a standardized stream bed is assumed, then a discharge can be calculated from the mean area and velocity measurements. The calculated range for flowing streams is $1.5 \mathrm{ft}^{3} / \mathrm{s}$ (left fork Mud River) to $37 \mathrm{ft}^{3} / \mathrm{s}$ (Twentymile Creek lower). The estimated discharges for pairs of streams sites are:

\section{- Twentymile Creek: lower 14.9; upper, $13.4 \mathrm{ft}^{3} / \mathrm{s}$}

- Clear Fork: lower 37; upper $4.6 \mathrm{ft}^{3} / \mathrm{s}$

- Mud River: lower, 17.3; upper, $18.0 \mathrm{ft}^{3} / \mathrm{s}$

For comparison, estimated median discharges were provided by the WVDEP (J. Wirts, written commun., 2013) (table 17). These estimated medians are considered an improvement over those discharges calculated using the method above. From table 17, the estimated range of median discharge for streams is $0.4 \mathrm{ft}^{3} / \mathrm{s}$ at Upton Branch to $27.4 \mathrm{ft}^{3} / \mathrm{s}$ at the Birch River. The estimated median discharges for pairs of streams sites are:

- Twentymile Creek: lower 23.8; upper, $13.8 \mathrm{ft}^{3} / \mathrm{s}$

- Clear Fork: lower 14.6; upper $6.2 \mathrm{ft}^{3} / \mathrm{s}$

- Mud River: lower, 9.5; upper, $7.2 \mathrm{ft}^{3} / \mathrm{s}$ 

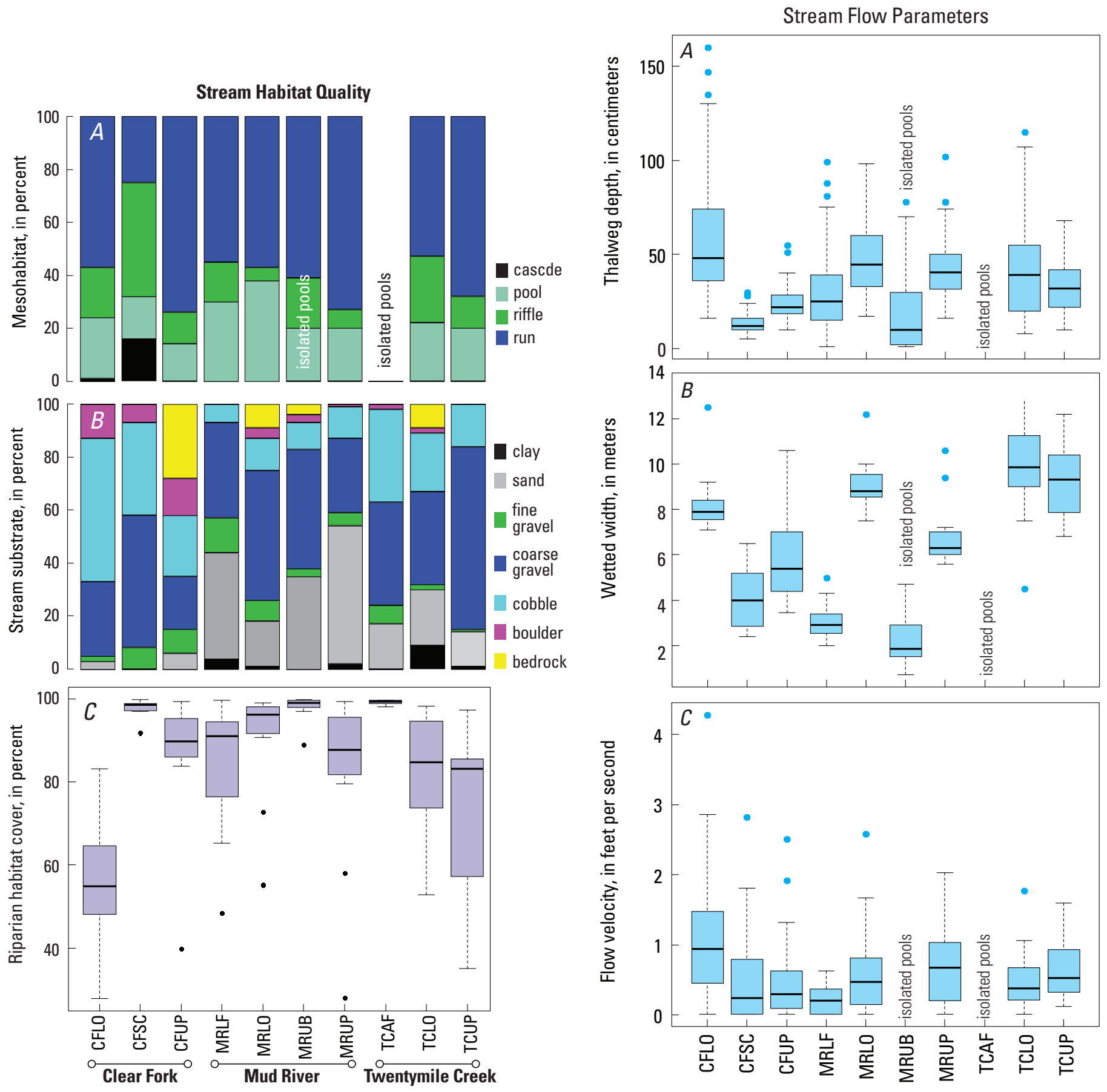

Figure 29. Bar graphs and boxplots showing variation in stream parameters measured at USGS sites in southern West Virginia during 2010. A, Mesohabitat. $B$, Stream substrate. C, Riparian habitat cover. CFLO, Clear Fork lower; CFSC, Sycamore Creek; CFUP, Clear Fork upper; MRLF, left fork Mud River; MRLO, Mud River lower; MRUB, Upton Branch; MRUP, Mud River upper; TCAF, Ash Fork; TCLO, Twentymile Creek, lower; TCUP, Twentymile Creek, upper.

Figure 30. Boxplots showing variation of physical habitat parameters measured at USGS sites in southern West Virginia during 2010. $A$, Thalweg depth. $B$, Wetted width. $C$, Flow velocity. CFLO, Clear Fork lower; CFSC, Sycamore Creek; CFUP, Clear Fork upper; MRLF, left fork Mud River; MRLO, Mud River lower; MRUB, Upton Branch; MRUP, Mud River upper; TCAF, Ash Fork; TCLO, Twentymile Creek, lower TCUP, Twentymile Creek upper. 
Table 14. Fish species and their abundance by site and sampling date.

[* one female specimen was observed with spinal deformities (lordosis) that are likely to be associated with Se toxicity; see photo in Lindberg and others (2011); dates in m/d/yyyy format; gray shading separates different sampled basins or sampling dates]

\begin{tabular}{|c|c|c|c|c|}
\hline Field site & Common name & Abundance & Common name & Abundance \\
\hline $\begin{array}{l}\text { Ash Fork } \\
3 / 18 / 2010 \\
\text { species }=6\end{array}$ & $\begin{array}{l}\text { Blacknose dace } \\
\text { Central stoneroller } \\
\text { Creek chub }\end{array}$ & & $\begin{array}{l}\text { Northern hog sucker } \\
\text { Rock bass } \\
\text { Spotfin shiner }\end{array}$ & \\
\hline $\begin{array}{l}\text { Twentymile Creek, lower } \\
10 / 14 / 2010 \\
\text { abundance }=43 \\
\text { species }=10\end{array}$ & $\begin{array}{l}\text { Bigmouth chub } \\
\text { Central stoneroller } \\
\text { Creek chub } \\
\text { Northern hog sucker } \\
\text { Rainbow darter }\end{array}$ & $\begin{array}{r}2 \\
16 \\
5 \\
5 \\
4\end{array}$ & $\begin{array}{l}\text { Rock bass } \\
\text { Smallmouth bass } \\
\text { Striped shiner } \\
\text { Telescope shiner } \\
\text { Whitetail shiner }\end{array}$ & $\begin{array}{l}4 \\
2 \\
3 \\
1 \\
1\end{array}$ \\
\hline $\begin{array}{l}\text { Twentymile Creek, upper } \\
9 / 29 / 2010 \\
\text { abundance }=66 \\
\text { species }=9\end{array}$ & $\begin{array}{l}\text { Bigmouth chub } \\
\text { Central stoneroller } \\
\text { Creek chub } \\
\text { Northern hog sucker } \\
\text { Rainbow darter }\end{array}$ & $\begin{array}{r}4 \\
20 \\
17 \\
7 \\
5\end{array}$ & $\begin{array}{l}\text { Rock bass } \\
\text { Rosyface shiner } \\
\text { Striped shiner } \\
\text { Telescope shiner }\end{array}$ & $\begin{array}{l}3 \\
1 \\
4 \\
5\end{array}$ \\
\hline $\begin{array}{l}\text { Twentymile Creek, upper } \\
4 / 20 / 2011 \\
\text { species }=5\end{array}$ & $\begin{array}{l}\text { Central stoneroller } \\
\text { Creek chub } \\
\text { Green sunfish }\end{array}$ & & $\begin{array}{l}\text { Northern hog sucker } \\
\text { Smallmouth bass }\end{array}$ & \\
\hline $\begin{array}{l}\text { White Oak Creek } \\
4 / 19 / 2011 \\
\text { species }=11\end{array}$ & $\begin{array}{l}\text { Banded darter } \\
\text { Bluntnose minnow } \\
\text { Central stoneroller } \\
\text { Creek chub } \\
\text { Green sunfish } \\
\text { Northern hog sucker }\end{array}$ & & $\begin{array}{l}\text { Rainbow darter } \\
\text { River chub } \\
\text { Rock bass } \\
\text { Smallmouth bass } \\
\text { Striped shiner }\end{array}$ & \\
\hline Seng Creek 4/19/2011 & Blacknose dace & & Creek chub & \\
\hline $\begin{array}{l}\text { Sycamore Creek } \\
10 / 1 / 2010 \\
\text { abundance }=151 \\
\text { species }=5\end{array}$ & $\begin{array}{l}\text { Blacknose dace } \\
\text { Central stoneroller } \\
\text { Creek chub }\end{array}$ & $\begin{array}{r}45 \\
1 \\
20\end{array}$ & $\begin{array}{l}\text { Fantail darter } \\
\text { Mottled sculpin }\end{array}$ & $\begin{array}{l}20 \\
65\end{array}$ \\
\hline $\begin{array}{l}\text { Sycamore Creek } \\
4 / 18 / 2011 \\
\text { species }=5\end{array}$ & $\begin{array}{l}\text { Blacknose dace } \\
\text { Central stoneroller } \\
\text { Creek chub }\end{array}$ & & $\begin{array}{l}\text { Fantail darter } \\
\text { Mottled sculpin }\end{array}$ & \\
\hline $\begin{array}{l}\text { Clear Fork, lower } \\
10 / 13 / 2010 \\
\text { species }=17\end{array}$ & $\begin{array}{l}\text { Banded darter } \\
\text { Bigeye chub } \\
\text { Blacknose dace } \\
\text { Central stoneroller } \\
\text { Creek chub } \\
\text { Fantail darter } \\
\text { Green sunfish } \\
\text { Greenside darter } \\
\text { Longnose dace }\end{array}$ & & $\begin{array}{l}\text { Mottled sculpin } \\
\text { Northern hog sucker } \\
\text { River chub } \\
\text { Rock bass } \\
\text { Rosyface shiner } \\
\text { Silver shiner } \\
\text { Smallmouth bass } \\
\text { Striped shiner }\end{array}$ & \\
\hline $\begin{array}{l}\text { Clear Fork, upper } \\
10 / 13 / 2010 \\
\text { species }=10\end{array}$ & $\begin{array}{l}\text { Blacknose dace } \\
\text { Central stoneroller } \\
\text { Creek chub } \\
\text { Greenside darter } \\
\text { Least brook lamprey }\end{array}$ & & $\begin{array}{l}\text { Mottled sculpin } \\
\text { Northern hog sucker } \\
\text { Rainbow darter } \\
\text { River chub } \\
\text { White sucker }\end{array}$ & \\
\hline $\begin{array}{l}\text { Clear Fork, upper } \\
4 / 18 / 2011 \\
\text { species }=9\end{array}$ & $\begin{array}{l}\text { Blacknose dace } \\
\text { Central stoneroller } \\
\text { Creek chub } \\
\text { Green sunfish } \\
\text { Greenside darter }\end{array}$ & & $\begin{array}{l}\text { Mottled sculpin } \\
\text { Northern hog sucker } \\
\text { Rainbow darter } \\
\text { White sucker }\end{array}$ & \\
\hline
\end{tabular}


Table 14. Fish species and their abundance by site and sampling date.-Continued

[* one female specimen was observed with spinal deformities (lordosis) that are likely to be associated with Se toxicity; see photo in Lindberg and others (2011); dates in m/d/yyyy format; gray shading separates different sampled basins or sampling dates]

\begin{tabular}{|c|c|c|c|c|}
\hline Field site & Common name & Abundance & Common name & Abundance \\
\hline \multirow{11}{*}{$\begin{array}{l}\text { left fork Mud River } \\
9 / 30 / 2010 \\
\text { abundance }=338 \\
\text { species }=21\end{array}$} & Blacknose dace & 1 & Longear sunfish & 10 \\
\hline & Blackside darter & 6 & Northern hog sucker & 6 \\
\hline & Bluntnose minnow & 42 & Rainbow darter & 1 \\
\hline & Central stoneroller & 2 & Redfin shiner & 8 \\
\hline & Creek chub & 103 & Rock bass & 2 \\
\hline & Fantail darter & 1 & Silverjaw minnow & 21 \\
\hline & Golden redhorse & 1 & Spotted bass & 2 \\
\hline & Green sunfish & 17 & Striped shiner & 56 \\
\hline & Johnny darter & 20 & White sucker & 10 \\
\hline & Least brook lamprey & 24 & Yellow bullhead & 1 \\
\hline & Logperch darter & 4 & & \\
\hline \multirow{9}{*}{$\begin{array}{l}\text { left fork Mud River } \\
5 / 3 / 2011 \\
\text { species }=18\end{array}$} & Blacknose dace & & Logperch darter & \\
\hline & Blackside darter & & Longear sunfish & \\
\hline & Bluntnose minnow & & Northern hog sucker & \\
\hline & Central stoneroller & & Pumpkinseed sunfish & \\
\hline & Creek chub & & Rainbow darter & \\
\hline & Fantail darter & & Redfin shiner & \\
\hline & Green sunfish & & Striped shiner & \\
\hline & Johnny darter & & White sucker & \\
\hline & Least brook lamprey & & Yellow bullhead & \\
\hline \multirow{7}{*}{$\begin{array}{l}\text { Mud River, lower } \\
10 / 12 / 2010 \\
\text { abundance }=70 \\
\text { species }=17\end{array}$} & Blacknose dace & 2 & Logperch darter & 2 \\
\hline & Bluntnose minnow & 2 & Northern hog sucker & 6 \\
\hline & Central stoneroller & 12 & Popeye shiner & 2 \\
\hline & Creek chub & 11 & Rainbow darter & 1 \\
\hline & Golden redhorse & 1 & Silver shiner & 4 \\
\hline & Green sunfish & 18 & Striped shiner & 5 \\
\hline & Greenside darter & 3 & White sucker & 1 \\
\hline \multirow{5}{*}{$\begin{array}{l}\text { Mud River, upper } \\
\text { 9/30/2010 } \\
\text { abundance }=68 \\
\text { species }=9\end{array}$} & Central stoneroller & 6 & Popeye shiner & 1 \\
\hline & Creek chub* & 25 & Rainbow darter & 2 \\
\hline & Green sunfish & 25 & Rock bass & 1 \\
\hline & Logperch darter & 1 & White sucker & 2 \\
\hline & Northern hog sucker & 5 & & \\
\hline \multirow{4}{*}{$\begin{array}{l}\text { Mud River, upper } \\
5 / 2 / 2011 \\
\text { species }=8\end{array}$} & Banded darter & & Green sunfish & \\
\hline & Central stoneroller & & Northern hog sucker & \\
\hline & Creek chub & & Rainbow darter & \\
\hline & Golden redhorse & & Sand shiner & \\
\hline Cabin Creek 4/21/2011 & Blacknose dace & & Creek chub & \\
\hline Beech Creek & Central stoneroller & & Mottled sculpin & \\
\hline $4 / 21 / 2011$ & Creek chub & & Northern hog sucker & \\
\hline \multirow[t]{3}{*}{ species $=10$} & Green sunfish & & Rainbow darter & \\
\hline & Greenside darter & & Striped shiner & \\
\hline & Largemouth bass & & White sucker & \\
\hline Birch River & Central stoneroller & & Mottled sculpin & \\
\hline $4 / 20 / 2011$ & Creek chub & & Northern hog sucker & \\
\hline species $=6$ & Fantail darter & & River chub & \\
\hline
\end{tabular}


Table 15. Number of darter species (benthic insectivores) present, species abundance, and number of sampling visits during monitoring in 2010 and 2011.

\begin{tabular}{lcccc}
\hline \multicolumn{1}{c}{ Field site } & $\begin{array}{c}\text { Number of } \\
\text { darter } \\
\text { species }\end{array}$ & $\begin{array}{c}\text { Number of } \\
\text { richness } \\
\text { visits }\end{array}$ & Abundance & $\begin{array}{c}\text { Number of } \\
\text { abundance } \\
\text { visits }\end{array}$ \\
\hline Ash Fork & 0 & 1 & not counted & 0 \\
Twentymile lower & 1 & 1 & 4 & 1 \\
Twentymile upper & 1,0 & 2 & 5 & 1 \\
\hline White Oak Creek & 2 & 1 & not counted & 0 \\
Seng Creek & 0 & 1 & not counted & 0 \\
Sycamore Creek & 1,1 & 2 & 20 & 1 \\
Clear Fork lower & 3 & 1 & not counted & 0 \\
Clear Fork upper & 2,2 & 2 & not counted & 0 \\
\hline left Fork Mud River & 5,5 & 2 & 32 & 1 \\
Upton Branch & not visited & not visited & not visited & not visited \\
Mud River lower & 3 & 1 & 6 & 1 \\
Mud River upper & 2,2 & 2 & 3 & 1 \\
\hline Cabin Creek & 0 & 1 & not counted & 0 \\
\hline Beech Creek & 2 & 1 & not counted & 0 \\
\hline Birch River & 1 & 1 & not counted & 0 \\
\hline
\end{tabular}

Table 16. Selenium concentrations in reproductive tissue (ovary) of fish collected during 2010 and 2011.

[Dates in $\mathrm{m} / \mathrm{d} / \mathrm{yyyy}$ format; $\mathrm{n}=$ number of samples, $\mu \mathrm{g} / \mathrm{g} \mathrm{dw}$, micrograms per gram dry weight; gray shading separates different sampled basins]

\begin{tabular}{|c|c|c|c|c|c|}
\hline \multirow{2}{*}{ Field name } & \multirow{2}{*}{ Site name } & \multirow{2}{*}{ Date } & \multirow{2}{*}{$\mathbf{n}$} & \multicolumn{2}{|c|}{ Ovary Se, in $\mu \mathrm{g} / \mathrm{g} \mathrm{dw}$} \\
\hline & & & & Range & Mean \\
\hline \multirow[t]{2}{*}{ Ash Fork } & TCAF & 2010 & 0 & & \\
\hline & & $4 / 20 / 2011$ & 2 & $3.8,4.2$ & 4.0 \\
\hline \multirow[t]{2}{*}{ Twentymile Creek lower } & TCLO & $4 / 15 / 2010$ & 1 & 10.6 & \\
\hline & & 2011 & 0 & & \\
\hline \multirow[t]{2}{*}{ Twentymile Creek upper } & TCUP & $3 / 25 / 2010$ & 3 & $9.3-12.2$ & 10.8 \\
\hline & & $4 / 20 / 2011$ & 4 & $8.3-12.6$ & 10.6 \\
\hline \multirow[t]{2}{*}{ Seng Creek } & SECR & 2010 & 0 & & \\
\hline & & $4 / 19 / 2011$ & 2 & $9.4,12.3$ & 10.8 \\
\hline \multirow[t]{2}{*}{ Sycamore Creek } & CFSC & $3 / 18 / 2010$ & 10 & $5.1-10.3$ & 6.8 \\
\hline & & $4 / 18 / 2011$ & 5 & $4.5-6.9$ & 5.4 \\
\hline \multirow[t]{2}{*}{ Clear Fork lower } & CFLO & $4 / 15 / 2010$ & 6 & $5.8-12.3$ & 7.3 \\
\hline & & 2011 & 0 & & \\
\hline \multirow[t]{2}{*}{ Clear Fork upper } & CFUP & $3 / 18 / 2010$ & 10 & $3.1-5.4$ & 3.9 \\
\hline & & $4 / 18 / 2011$ & 5 & $3.3-4.3$ & 3.9 \\
\hline \multirow[t]{2}{*}{ left fork Mud River } & MRLF & $3 / 23 / 2010$ & 1 & 5.8 & \\
\hline & & $5 / 3 / 2011$ & 2 & $4.0,4.7$ & 4.4 \\
\hline \multirow[t]{2}{*}{ Upton Branch } & MRUB & $3 / 17 / 2010$ & 3 & $5.1-5.8$ & 5.4 \\
\hline & & 2011 & 0 & & \\
\hline \multirow[t]{2}{*}{ Mud River upper } & MRUP & $3 / 24 / 2010$ & 5 & $16.4-22.2$ & 18.4 \\
\hline & & $5 / 2 / 2011$ & 1 & 9.8 & \\
\hline \multirow[t]{2}{*}{ Cabin Creek } & CACR & 2010 & 0 & & \\
\hline & & $4 / 21 / 2011$ & 2 & $9.0,9.4$ & 9.2 \\
\hline \multirow[t]{2}{*}{ Birch River } & BIRI & 2010 & 0 & & \\
\hline & & $4 / 20 / 2011$ & 4 & $6.3-7.9$ & 7.2 \\
\hline
\end{tabular}


Table 17. Estimated median discharges for streams sampled in 2010 and 2011.

[J. Wirts, written commun., 2013; $\mathrm{ft}^{3} / \mathrm{s}$, cubic feet per second]

\begin{tabular}{lcc}
\hline \multicolumn{1}{c}{ Field site } & Field name & $\begin{array}{c}\text { Mean } \\
\text { discharge } \\
\left(\mathbf{f t}^{3} \mathbf{s}\right)\end{array}$ \\
\hline Upton Branch & MRUB & 0.4 \\
\hline Ash Fork & TCAF & 1.6 \\
\hline Seng Creek & SECR & 2.1 \\
\hline left fork Mud River & MRLF & 2.4 \\
\hline Sycamore Creek & CFSC & 4.1 \\
\hline Beech Creek & BECR & 5.0 \\
\hline Clear Fork upper & CFUP & 6.2 \\
\hline Mud River upper & MRUP & 7.2 \\
\hline Mud River lower & MRLO & 9.5 \\
\hline White Oak Creek & WOCR & 12.3 \\
\hline Twentymile Creek upper & TCUP & 13.8 \\
\hline Clear Fork lower & CFLO & 14.6 \\
\hline Cabin Creek & CACR & 18.8 \\
\hline Twentymile Creek lower & TCLO & 23.8 \\
\hline Birch River & BIRI & 27.4 \\
\hline
\end{tabular}

Discharge can be connected to water residence time and hence to effects on Se partitioning between dissolved and particulate Se phases and characterization of $\mathrm{K}_{\mathrm{d}}$ (see earlier discussion in "Links to Dissolved Se Concentrations: $\mathrm{K}_{\mathrm{d}} \mathrm{s}$ " section). However, more than a one-season sampling is needed to place a stream site in a category and connect that category to modeling parameters (for example, $\mathrm{K}_{\mathrm{d}}$ ). A stream-gaging network would be a valuable asset to add to modeling studies to enable a seasonal component and potentially an in-depth categorizing of discharge and $\mathrm{K}_{\mathrm{d}}$ (see also figs. 25-28 and discussion in "Streams Detail" section).

Ecologically, these descriptive physical and stream attributes could be connected to invertebrate and fish community data (that is, habitat use by seasonal inhabitants) and, potentially, added as components of ecosystem-scale Se modeling. Proximity to identified mine sites and valley fills also is of importance to quantify as a landscape parameter that can be represented in modeling scenarios. Overall, characteristics of mine sites as recorded in streams could be tracked in terms of dissolved and particulate Se concentrations to provide a historical management perspective of ecosystem conditions as coal mines are established and then become inactive.

\section{Conclusions}

The methodology components of this study address the interdisciplinary monitoring, synthesis, and modeling necessary to understand and quantify the hydrologic conditions, species specificity, and site-specific food web Se exposures within southern
West Virginia riverine, reservoir, and pond ecosystems. Spatially and temporally matched datasets across media (that is, water, suspended particulate material, prey, and predator) are fundamental to modeling and to provision of ecologically consistent predictions. Model results are specific to Se, but are within general landscape changes, food-web disruption, and recolonization potential present in mountaintop coal mining and valley-fill regions of southern West Virginia. Demographically open systems such as streams that lead into reservoirs or aquatic environments with changing hydrologic and food-web conditions also add complexity to modeling and derivation of environmentally safe Se concentrations for watersheds and fish communities.

The intent here was to develop and validate a site-specific model and illustrate the model's capability under varying sitespecific hydrologic and food-web conditions, mainly those conditions useful to management decisions. The choices of Se exposure that are illustrated set model outcomes within site-specific scenarios, but the overall outcomes and implications will be those generated by the choices and guidance given by state and other agencies in their decisionmaking processes. The range of those modeling outcomes accounts for critical sources of variability and establishes an understanding of relevant and controlling variables, while the site-specific model itself advances the ability to explain why bioaccumulation of Se differs among the aquatic environments and food webs of southern West Virginia.

Modeling that constrains the place and time of greatest ecosystem Se sensitivity within a specified food web gives insight into Se risk within a watershed or stream basin. If there is a range of hydrologic settings, specificity is needed to establish a hierarchy of in-stream and off-stream habitats for a watershed approach that takes into account Se-enriched water moving through different $\mathrm{K}_{\mathrm{d}}$ and food-web environments. If there is a range of predator vulnerabilities (measured as a combination of food-web Se biodynamics and response in Se toxicity tests) within a site-specific community of fish species to be protected, then choice of fish species is critical to protection because it determines the food web, and hence, the magnitude of biotransfer through which Se is modeled.

Critical choices for predictive Se scenarios include

- location within the Se source gradient

- hydrologic residence time (reservoir, pond, stream)

- biogeochemical partitioning between dissolved and particulate Se $\left(\mathrm{K}_{\mathrm{d}}\right)$

- types of suspended particulate material that form base of food web

- predator's dietary preference (food-web components)

- $\mathrm{TTF}_{\text {invertebrate }}$ (major variability)

- $\operatorname{TTF}_{\text {fish }}$ (minor variability)

- species' inherent sensitivity to Se toxicity

- status of predator species (breeding, resident)

- habitat use (life cycle, prey availability)

- toxicity endpoint (acute reproduction, chronic adult) 
Whether creek chub, a species present at all sites, and stoneroller species targeted for this study are representative of the vulnerability of all fish species encountered within the study site ecosystems will require additional species-specific data and analysis. Previous studies of Se concentrations in different fish species for streams in the mountaintop coal mining area of southern West Virginia did not address food-web components (that is, fish species' dietary choice). However, the available studies showed a hierarchy for Se bioaccumulation among fish species as blacknose dace $\geq$ bluegill sunfish, $>$ green sunfish $>$ creek chub $>$ stoneroller in a stream hydrologic setting. For a reservoir hydrologic setting, the ranking was bluegill sunfish $>$ green sunfish $>$ largemouth bass. Fish community data as part of this study also documented the number of significant fish species that inhabit these ecosystems. Therefore, other species of fish than creek chub and stoneroller may set the precedent for protection if a full spectrum of fish species is sampled. Hence, modeling here is limited concerning quantifying the vulnerability of fish species in ecosystems affected by drainage of Se from mountaintop coal mines and valley fills.

In sum, ecosystem-scale modeling offers a major step forward in terms of confronting ecology and in understanding, quantifying, and formalizing the knowledge necessary to understand the basis of Se risk, differential Se bioaccumulation across food webs, and protective criteria for Se. This formalization of knowledge, including choices used to initiate or constrain modeling scenarios, thus clearly documents pathways that connect dissolved and tissue Se concentrations and provides a record of supporting data throughout decisionmaking phases.

Detailed site-specific results follow concerning the many aspects of this assessment, model development, and model application. A list of model refinements that could help to reduce uncertainty in modeling also is given.

\section{Assessment}

The study of southern West Virginia basins and ecosystems affected by mountaintop coal mining and valley fills was focused on:

- Se assessment based on ecologically consistent food-web sampling (that is, collection of spatially and temporally matched samples across water, suspended particulate material, prey, and predator) and

- ecosystem-scale Se model development to predict sitespecific Se bioaccumulation in fish species and their diets and, hence, Se ecological risk for predators.

Sampling during 2010 and 2011 was across 6 basins and 15 sites within southern West Virginia (tables 2 and 3), where the majority of valley fills are found (fig. 4). Valley fills have been shown to have increased within this region during the period 1984-2009, with the progression of fill construction approximately linear in terms of cumulative area but exhibiting a 7.5-fold increase overall (fig. 1). A Se pathway and various hydrologic settings (stream, reservoir, pond, and outfall) in a generalized schematic of the mountaintop coal mining process and valley fill landscape provides a locational and hydrologic framework for modeling (fig. 5).

Basin schematics (figs. 11-15) give a comprehensive view of sampled species and observed Se concentration data specific to location and date. Food-web diagrams (figs. 16-20) document the progression of Se trophic transfer and, in most cases, Se biomagnification, across suspended particulate material, invertebrate, and fish (wb) for each site. Fish ovary Se concentrations also are shown to document Se concentrations in reproductive tissue during March and May 2010. Dissolved Se concentrations and dissolved Se speciation measured across several months in both 2010 and 2011 enabled consideration of stream variability with time (fig. 21). Suspended-particulate-material Se concentrations document the transformation of dissolved Se to particulate Se at the base of the food web for 2011 only. Aquatic insects (mayfly, caddisfly, dragonfly, stonefly, dobsonfly, chironomid) were assessed as prey taxa. Fish species collected for Se assessment in streams were limited to creek chub and central stoneroller, even though site-specific fish abundance and richness data documented species of chub, shiner, dace, darter, bass, minnow, sunfish, sculpin, sucker, and catfish. However, creek chub were present at all sampling sites.

Sampled aquatic insect taxa generally showed a similar degree of Se bioaccumulation, but with some variation among sorted sampling groups (composite or single taxon). Across all sites, highest Se concentrations among aquatic insects were found in chironomid, caddisfly, stonefly, and dobsonfly (figs. 16-19). No initial differences in bioaccumulation between creek chub and central stoneroller were found, although sites where both fish were present were limited to four sites. Seasonal differences among fish Se concentrations ( $w b d w$ ) were apparent, with increased Se concentrations during spring (fig. 20). A time series (April 2010 to June 2011) of dissolved Se concentration added a temporal component on which to base modeling (figs. 7 and 21). Such factors as time of snow melt and exposures during a possible flush of Se in spring (fig. 21A) further delineated basin hydrology. Dissolved Se speciation in streams was dominated by selenate $(82-100$ percent), with seasonal peaks in organo-Se speciation in spring and summer (table 6; figs. 16-19). Therefore, elevated sensitivity of site-specific ecosystems to $\mathrm{Se}$ is possible in spring and summer based on Se speciation.

In general, across sites for the 2010 and 2011 assessment, mean observed Se concentrations (wb dw) in creek chub and stoneroller were highest at the Mud River upper (mean, $8.1 \mu \mathrm{g} / \mathrm{g}$; range $5.0-11.1 \mu \mathrm{g} / \mathrm{g}$ ) and Seng Creek (mean, 8.1 $\mu \mathrm{g} / \mathrm{g}$; range $5.4-10.3 \mu \mathrm{g} / \mathrm{g}$ ) sites, with all fish equaling or exceeding the lower toxicity guideline of $5.0 \mu \mathrm{g} / \mathrm{g}$ ( $\mathrm{wb} \mathrm{dw}$ ) considered here. Both mean Se concentrations for these sites slightly exceeded the upper toxicity guideline of $7.9 \mu \mathrm{g} / \mathrm{g}$ (wb dw). Cabin Creek and White Oak Creek sites yielded similar maximum Se concentrations in fish (11.2 and 9.6 $\mu \mathrm{g} / \mathrm{g}$, respectively), but lesser means (6.7 and $6.0 \mu \mathrm{g} / \mathrm{g}$ ). Mean observed Se concentrations (tissue $\mathrm{dw}$ ) in invertebrates as a 
measure of dietary risk exceeded the guidelines of $4.5 \mu \mathrm{g} / \mathrm{g}$ $\mathrm{dw}$ and $7.2 \mu \mathrm{g} / \mathrm{g}$ considered here in at least one site in each basin: Twentymile Creek upper, $9.2 \mu \mathrm{g} / \mathrm{g}$; White Oak Creek, $10.8 \mu \mathrm{g} / \mathrm{g}$; Seng Creek, $11.0 \mu \mathrm{g} / \mathrm{g}$; Mud River lower, $8.0 \mu \mathrm{g} / \mathrm{g}$; Mud River upper, $11.7 \mu \mathrm{g} / \mathrm{g}$; Cabin Creek, $9.6 \mu \mathrm{g} / \mathrm{g}$; Beech Creek, $18.7 \mu \mathrm{g} / \mathrm{g}$; and the Birch River, $10.3 \mu \mathrm{g} / \mathrm{g}$. Invertebrate samples were not collected at the Clear Fork lower site, so no assessment could be made.

Additionally, an adult female creek chub with a spinal deformity (lordosis) that is likely to be associated with Se toxicity was found at the Mud River upper site during collection of fish in September 2010. Although the wb Se concentration of $6.7 \mu \mathrm{g} / \mathrm{g} \mathrm{dw}$ is not indicative of the Se concentration that led to the deformity, reproductive tissue (ovary) Se concentrations at this site ranged from 16.4 to 22.2 $\mu \mathrm{g} / \mathrm{g} \mathrm{dw}$, with a mean ovary Se concentration of $18.4 \mu \mathrm{g} / \mathrm{g} \mathrm{dw}$ in March 2010. All of these Se concentrations exceeded both ovary toxicity guidelines illustrated here (6.5 and $11 \mu \mathrm{g} / \mathrm{g} \mathrm{dw})$.

\section{Site-Specific Model Development and Validation}

The modeling approach used (1) conceptual models and exposure scenarios based on site-specific knowledge of food webs and hydrologic setting to set modeling parameters and constraints (fig. 22) and (2) a mechanistic biodynamic basis that drives physiological processes specific to each prey and predator species to quantify bioaccumulation (fig. 6). The model generated prey (aquatic insect, crayfish, clam, snail) and fish (creek chub, stoneroller, bluegill sunfish, green sunfish) Se concentrations from Se concentrations in suspended particulate material for stream and reservoir settings. Characterization of particulate material type, along with the determination of Se concentration (tables 6 and 7), is an important indicator of the dynamics at the base of food webs. Seasonal changes within water bodies such as streams may cause some phases to be absent (that is, during higher discharge), while time may be needed to reestablish additional phases through recycling opportunities in spring and summer. Variability in dissolved speciation gives some indication of this temporal effect for study sites (table 6; fig. 21). Eleven datasets for invertebrates and eight datasets for fish were available for validation of modeling (tables 4 and 5; figs. 23 and 24). Predicted and observed Se concentrations for prey and predators were highly correlated $\left(r^{2}=0.982\right.$ for invertebrates and 0.754 for fish) when modeling was initiated from suspended-particulate-material Se concentrations and model transfer parameters defined previously in the literature were used. For streams, the range of predicted invertebrate Se concentrations was $1.5-10.9 \mu \mathrm{g} / \mathrm{g} \mathrm{dw}$, and the range of observed invertebrate Se concentrations was 0.8-11 $\mu \mathrm{g} / \mathrm{g} \mathrm{dw}$. The range of predicted fish Se concentrations in stream sites was 1.7 to $12 \mu \mathrm{g} / \mathrm{g}$ ( $w b \mathrm{dw}$ ), and the range of observed fish Se concentrations was 2.4 to $9.0 \mu \mathrm{g} / \mathrm{g}$. Modeling of the food-web exposure scenario for particulate material directly to stoneroller in streams showed lower predicted Se concentrations in fish (range 0.6-4.6 $\mu \mathrm{g} / \mathrm{g}$ wb dw) than in other scenarios (table 5). These predicted Se concentrations represent, in most cases, the lower end of the range of measured Se concentrations.

These strong correlations validate the derived sitespecific model and establish sufficient confidence that the predictions from the developed model can be quantitatively applied to the ecosystems in southern West Virginia. Consideration of assessment data (figs. 11-15), food-web compilations (figs. 16-19), and modeling (tables 4 and 5) in combination showed that the model is able to generate the conditions seen in the sampled basins and accurately predict Se concentrations in invertebrates and fish, components critical to ecosystem protection for Se.

In steps separate from modeling, site-specific factors were calculated from field data: $\mathrm{TTF}_{\text {aquatic insect }}=2.6$; $\mathrm{TTF}_{\text {chironomid }}=4.2$; and $\mathrm{TTF}_{\text {fish }}=0.85$. The site-specific $\mathrm{TTF}$ for aquatic insect agreed well with the mean TTF for aquatic insect of 2.8 (range 2.3-3.2) reported in the literature (Luoma and Presser, 2009; Conley and others, 2009; Presser and Luoma, 2010a). The site-specific TTF for chironomid may indicate a higher biotransfer of Se for this aquatic insect than that represented by a value of 2.7 reported in the literature (Presser and Luoma, 2010a). The site-specific TTFs for creek chub and stoneroller were below the compiled species mean given in the literature of 1.1 (Presser and Luoma, 2010a). This result (that is, $\mathrm{TTF}_{\text {fish }}<1$, with Se concentrations in fish less than those in their food) shows a comparatively inefficient transfer from aquatic insect to creek chub and stoneroller than that given in the literature for several species of fish ( 0.85 versus 1.1$)$. There is also indication that biotransfer for stoneroller may be even lower than for creek chub, but the dataset was small in terms of both number of sites and fish sampled. However, limitations in the fish species sampled here restricted conclusions about other fish species and their potential for bioaccumulation and vulnerability.

\section{Model Application}

Ecosystem-scale Se modeling can be applied to translate an assumed regulatory fish-tissue Se target ( $w b \mathrm{dw}$ ) to a dissolved Se concentration under a set of site-specific exposure scenarios for the sampled basins. This application is an example of the site-specific implementation of a nationally proposed fish-tissue criterion that is designed to protect a designated percentage of fish species at a specified effect concentration. This application uses an additional modeling metric that describes partitioning of Se between particulate material and dissolved phases (that is, $\mathrm{K}_{\mathrm{d}}$ ) to quantitatively link dissolved Se concentrations to the chosen toxicity guideline. $\mathrm{K}_{\mathrm{d}} \mathrm{s}$ are operationally defined and considered to be an instantaneous measurement that quantifies the complex transformations at the base of a site-specific food web.

The range of outcomes of this application can show the implications of management decisions and tie dissolved Se concentration to Se toxicity as long as intervening steps are adhered 
to and sufficient data are available. The parameters used in the exposure scenarios are key to understanding the range of model outcomes. The parameters and range of outcomes reflect species and hydrologic-setting specificity and not uncertainty in modeling (see "Model Outcomes and Validation" section). The model outcomes also illustrate the maximum potential of the system for Se bioaccumulation in an ecologically consistent manner across media (water, particulate material, prey, and predator tissue).

The specific question addressed in this application (tables 8-11) was: What are the implications for ecosystem concentrations of Se if a fish-tissue Se guideline of $7.9 \mu \mathrm{g} / \mathrm{g}$ ( $w b \mathrm{dw}$ ) (that is, USEPA's proposed fish tissue guideline) or $5 \mu \mathrm{g} / \mathrm{g}(\mathrm{wb} \mathrm{dw}$ ) (that is, a guideline indicative of protecting endangered species) is implemented? A range of field-derived $\mathrm{K}_{\mathrm{d}} \mathrm{s}$ (tables 6 and 7) are applied in site- and time-specific exposure scenarios that illustrate a suite of ecologically realistic food webs for stream, reservoir, and pond hydrologic settings (fig. 22; tables 8-11). In general, these quantitative exposure scenarios are a balance between strict site-specific species scenarios and species scenarios that illustrate the fundamental mathematics of Se exposure as derived from species-specific Se biodynamics (that is, invertebrate TTFs are primary to fish vulnerability). In some instances, choices also can represent mathematical end-members to show the limits of ecological sensitivity to model parameters. Overall, the model application and synopsis given here delineate a range of choices that can be specifically addressed to narrow outcomes based on the input of decisionmakers (tables 8-11).

For a fish-tissue guideline of $7.9 \mu \mathrm{g} / \mathrm{g}$ ( $\mathrm{wb} \mathrm{dw}$ ), the range of predicted dissolved Se concentrations is 1.9 to $14.2 \mu \mathrm{g} / \mathrm{L}$ for the base-case food web (suspended particulate material to aquatic insect to creek chub) and the June 2008 and 2011 set of stream sites and their associated $\mathrm{K}_{\mathrm{d}} \mathrm{s}$ (tables 8 and 9). The predicted range is $3.0-8.3 \mu \mathrm{g} / \mathrm{L}$ for the base-case food web and the February-March 2011 set of sites and their associated $\mathrm{K}_{\mathrm{d}} \mathrm{S}$ (tables 8 and 9). If the predictions are constrained to $\mathrm{K}_{d} \mathrm{~s}>310$, then the range of dissolved Se concentrations for the basecase food web across all sites is narrowed to $1.9-5.1 \mu \mathrm{g} / \mathrm{L}$. Deviations from the base-case food web across the range of hydrologic conditions in streams shows that inclusion of

- a clam or chironomid food web would decrease predicted dissolved Se concentrations (ranges: June, 1.3-10 $\mu \mathrm{g} / \mathrm{L}$; February-March , 2.1-5.8 $\mu \mathrm{g} / \mathrm{L})$;

- a forage fish to predator fish food web would decrease predicted dissolved Se concentrations (ranges: June, $1.7-13 \mu \mathrm{g} / \mathrm{L}$; February-March , 2.7-7.5 $\mu \mathrm{g} / \mathrm{L}$ )

- a particulate to stoneroller food web would increase predicted dissolved Se concentrations (ranges: June, 5.3-40

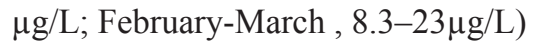

- a $\mathrm{TTF}_{\text {fish }}$ of $<1$ (that is, indicating a comparatively inefficient transfer from invertebrate to fish) would increase predicted dissolved Se concentrations (ranges: June, 3.0-22 $\mu \mathrm{g} / \mathrm{L}$; February-March , 4.6-13 $\mu \mathrm{g} / \mathrm{L}$ ).
If the site-specific, field-derived $\mathrm{TTF}_{\text {snail }}$ of 5.5 is used in predictive scenarios, then a food web that includes snails would decrease the predicted dissolved Se concentrations even further than those values derived for a clam or chironomid food web.

The food webs for reservoirs and ponds include species other than those found in streams (fig. 22). The range of predicted dissolved Se concentrations is $0.7-2.5 \mu \mathrm{g} / \mathrm{L}$ for food webs for the Upper Mud River Reservoir in June 2008 (tables 8 and 9). The range of predicted dissolved Se concentrations for valley-fill ponds is $2.0-4.5 \mu \mathrm{g} / \mathrm{L}$ in summer and $3.0-6.7 \mu \mathrm{g} / \mathrm{L}$ in winter (tables 8 and 9). If only a base-case food web (note: bluegill is substituted for creek chub, with $\mathrm{TTF}_{\text {fish }}$ remaining at 1.1; see fig. 22) is considered in a reservoir setting, the predicted dissolved Se concentration is $1.4 \mu \mathrm{g} / \mathrm{L}$. For a pond setting, the predicted dissolved Se concentration is $2.8 \mu \mathrm{g} / \mathrm{L}$ in summer and $4.3 \mu \mathrm{g} / \mathrm{L}$ in winter. The controlling food-web variables for the most restrictive dissolved Se concentrations in these hydrologic settings are $\operatorname{TTF}_{\text {snail }}(0.7 \mu \mathrm{g} / \mathrm{L})$ and a possible increased efficiency for $\operatorname{TTF}_{\text {bluegill }}(1.2 \mu \mathrm{g} / \mathrm{L})$.

Predicted dissolved Se concentrations for the illustrated food webs and a guideline of $5.0 \mu \mathrm{g} / \mathrm{g}$ fish ( $\mathrm{wb} \mathrm{dw}$ ) showed possible protection for endangered species (tables 10 and 11). Selenium concentrations are proportional, but lower than discussed above. For example, the highest predicted Se concentration is $25 \mu \mathrm{g} / \mathrm{L}$ and the lowest is $0.5 \mu \mathrm{g} / \mathrm{L}$ for the suite of illustrated scenarios.

From modeling, it is clear that reservoirs within basins and ponds at the toes of valley fills present the most consistent ecological Se risk based on modeling of hydrologic setting within a watershed. Food webs that contain clams, chironomids, or snails or that contain an additional step to adult fish also present consistent ecological Se risk based on species consuming a single component diet (fig. 22, tables $8-11)$. In contrast, mitigation of Se risk could occur in settings where stonerollers are directly consuming particulate material with no invertebrate step (that is, limitations in dietary choices). Comparatively lower biotransfer from invertebrate to fish than that given in the literature for several species of fish ( 0.85 versus 1.1$)$ may be the case for creek chub and stoneroller. In general, risk also can change (that is, be moderated or intensified) at different times within streams because of varying (1) water residence time (seasonal or water year) and (2) dissolved Se speciation (for example, selenite and organo-Se percentages increasing during spring and summer) (table 6; figs. 11-15).

Further specificity in model application for streams elucidated a level of framing that helps to understand, and possibly quantify, some of the underlying variables that affect $\mathrm{K}_{\mathrm{d}} \mathrm{s}$ and Se dynamics (figs. 25-28). This analysis has data limitations, but additional site-specific evaluation of hydrologic and landscape parameters in the future hopefully will help refine this approach. Streams are modeled in detail in these figures by expanding modeling to link stream gradient, order, discharge, and basin area, as well as seasonal patterns of Se source dynamics (see also figs. 7A,B, 21). Site-specific 
base-case scenarios (suspended particulate material to aquatic insect to creek chub) are illustrated in figures 25 and 26 for a fish-tissue guideline of $7.9 \mu \mathrm{g} / \mathrm{g}$ (wb dw) and in figs. 27 and 28 for a fish-tissue guideline of $5.0 \mu \mathrm{g} / \mathrm{g}$ (wb dw).

Schematics and $\mathrm{K}_{\mathrm{d}} \mathrm{s}$ are specific to month and year (February 2011, June 2011, June 2008), which acknowledges a temporal component to the model application. Comparison to observed dissolved Se concentrations and variability of dissolved Se in the stream with time show the magnitude of change necessary to adhere to the translated guideline. For the base-case scenario and a fish-tissue guideline $7.9 \mu \mathrm{g} / \mathrm{g}(\mathrm{wb} \mathrm{dw})$, predicted site-specific changes in dissolved Se concentrations for stream sites range from a possible increase of $1.4 \mu \mathrm{g} / \mathrm{L}$ for Twentymile Creek upper to a possible decrease of $9.0 \mu \mathrm{g} / \mathrm{L}$ for Seng Creek. Consideration of other food-web exposure scenarios (tables 8-11) would produce a range of dissolved Se outcomes rather than the single Se concentration illustrated in the schematic for each site. For example, including a more vulnerable species of fish than creek chub could be represented by a TTF of 1.3 , which lowers the outcome for Seng Creek to $12.2 \mu \mathrm{g} / \mathrm{L}$. Similarly, use of a fish tissue guideline $5-\mu \mathrm{g} / \mathrm{g}$ (wb dw) would further lower the predicted dissolved Se concentrations and require a larger decrease in stream Se concentration to adhere to the translated tissue guideline (figs. 27-28).

Also presented in figures 25-28 are predicted fish $\mathrm{Se}$ concentrations based on previous model runs (tables 4 and 5) and observed fish Se concentrations to help visualize current concentrations in comparison to a guideline of 5.0 or $7.9-\mu \mathrm{g} / \mathrm{g}$ (wb dw). Predicted dissolved Se concentrations for valley-fill ponds and the Upper Mud River Reservoir are shown for comparison of hydrologic setting, but note that food webs other than those for aquatic insects may dominate in these impoundments (figs. 8 and 11; tables 8-11). Thus, figures 25-28 provide examples of the type of analysis of landscape variables that can link to model parameters for streams. However, a finer scale for these types of variables, along with additional sampling for derivation of $\mathrm{K}_{\mathrm{d}} \mathrm{s}$ presented here, would help narrow uncertainty and categorize modeling sites within a basin or watershed. Thus, modeling outcomes using these hydrologic settings and food-web species would elucidate the controlling steps for management alternatives for a watershed or fish community approach.

\section{Linkage to Fish Species Abundance and Richness}

Investigating the presence and variability in prey and predator species in streams is important given the sitespecific stressors, including Se, imposed by mountaintop coal mining and valley fills on the composition of biological communities. Fish community data (tables 12-15) provided snapshots-in-time of species richness and abundance for initial study sites in fall and spring 2010. Richness data were available for 9 sites in fall 2010 and 10 sites in spring
2011, with cross-seasonal comparison possible for 5 sampled sites (table 12). Stream order (table 12) is a variable to consider when addressing species richness because fish diversity usually increases with increasing stream order. The generalized range of stream order for sites sampled here is second-order to fourth order, with six third-order streams.

Within the Mud River basin stream order for fall 2010, species richness increased going downstream, with the upper site yielding 9 species and the lower site 14 species. Similarly, Clear Fork upper yielded 10 species and the lower site 17 species during fall 2010. Twentymile Creek upper and lower had similar numbers of species ( 9 and 10, respectively). Ash Fork and Sycamore Creek yielded lower number of species (six and five, respectively). Left fork Mud River yielded the highest number of species with 21 species. For sites sampled only during April-May 2011, species richness was: White Oak Creek, 11; Seng Creek, 2; Cabin Creek, 2; Beech Creek, 10; and the Birch River, 6 (table 12). Darter species richness and abundance (table 15) is given as an example of a benthic insectivore's (table 1) presence in sampled streams. The highest numbers of darter species were found at left fork Mud River (5), Clear Fork lower (3), and Mud River lower (3). Sampling of other sites yielded one or two darter species, except for Ash Fork, Seng Creek, and Cabin Creek, where no darters were present.

The order of abundance for all sites and sampling periods for species with greater than or equal to 20 individuals during the times and places sampled was: creek chub, striped shiner, mottled sculpin, green sunfish, central stoneroller, blacknose dace, bluntnose minnow, northern hog sucker, least brook lamprey, silverjaw minnow, fantail darter, and johnny darter (tables 13 and 14). Shiners, darters, and bass were prevalent, but bluegill sunfish were absent during the 2010 survey. The number of species and species characteristics or traits (for example, tables 1 and 14) could be used to rank each site in terms of fish community health and diversity (for example, Index of Biotic Integrity) (for example, Karr, 1981).

\section{Model Refinements and Reduction in Uncertainty}

Proposed additions and refinements to the ecosystem-scale site-specific approach developed here include consideration of:

- measurement of temporally matched pairs of dissolved and suspended-particulate-material Se concentrations across a broader range of stream sites to expand the stream $\mathrm{K}_{\mathrm{d}}$ database and to test the representativeness of a suspended-particulate-material sample within a stream;

- characterization of different phases of particulate material across seasons to better define the base of the food web and connect to invertebrate feeding;

- refinement of model assumptions concerning dietary preferences and composition for fish to develop additional 
TTFs (for example, calculation of TTF mixed diets);

- expansion of modeling of fish species and their food webs to include Se-vulnerable species;

- temporal characterization of a predator's life cycle and habitat use as additional model layers to integrate with Se biodynamics in streams;

- investigation of the effect of stream gradient on $\mathrm{K}_{\mathrm{d}}$ based on a finer scale than presented here in terms of such variables as residence time, watershed dilution, and physical habitat attributes (for example, amount of ponding versus run or riffle within a stream); and

- linkage to discharge through use of stream gaging to record variability and enable model organization within wateryear types and discharge seasons.

Investigating the presence and variability of prey and predator species in demographically open systems such as streams also is key to model outcomes, given the overall environmental stressors (for example, general landscape change, food-web disruption, recolonization potential) imposed on the composition of biological communities in watersheds affected by coal mining and valley-fill.

\section{Acknowledgments}

This research was supported by the West Virginia Department of Environmental Protection (WVDEP), Division of Water and Waste Management; the U.S. Geological Survey (USGS) West Virginia Water Science and Leetown Science Centers; and the USGS National Research and Hydrologic Research and Development Programs. This report was made possible by the knowledge and expertise of the WVDEP and the USGS concerning the mountaintop coal mining and valley-fill region of southern West Virginia. At its base, this report relies on the sampling expertise provided by Douglas B. Chambers of the West Virginia Water Science Center, Charleston, West Virginia, and Nathaniel P. Hitt of the Leetown Science Center, Kearneysville, West Virginia. Selenium analyses were provided by Thomas W. May of the Columbia Environmental Research Center, Columbia, Missouri. Graphics were provided by Jeanne DiLeo of the USGS Menlo Park Publishing Service Center, Menlo Park, California. Mark Huebner (USGS, Menlo Park) provided geographic, technical, and manuscript preparation support. Thanks especially to Hugh Bevans of the USGS West Virginia Water Science Center and Patrick Campbell of the WVDEP Division of Water and Waste Management for giving me the opportunity to study and model the ecosystems of West Virginia. Thanks also to U.S. Environmental Protection Agency (Office of Water, Washington, D.C. and Region 9, San Francisco, California) for supporting work on both the broader ecosystem-scale Se modeling approach and its application on a site-specific basis.

\section{References Cited}

Baines, S.B., Fisher, N.S., and Stewart, R., 2002, Assimilation and retention of selenium and other trace elements from crustacean food by juvenile striped bass (Morone saxatilis): Limnology and Oceanography, v. 47, no. 3, p. 646-655.

Barbour, M.T., Gerritsen, J., Snyder, B.D., and Stribling, J.B., 1999, Rapid Bioassessment Protocols for Use in streams and Wadeable Rivers; Periphyton, Benthic Macroinvertebrates and Fish ( $2 \mathrm{~d}$ ed.): Washington, D.C. U.S. Environmental Protection Agency, Office of Water, accessed online August 20, 2013, at http://water.epa.gov/ scitech/monitoring/rsl/bioassessment/download.cfm.

Bernhardt, E.S., Lutz, B.D., King, R.S., Fay, J.P., Carter, C.E., Helton, A.M., Campagna, D., and Amos, J., 2012, How many mountains can we mine? - assessing the regional degradation of central Appalachian rivers by surface coal mining: Environmental Science and Technology, v. 46, no. 15, p. 8115-8122.

Besser, J.M., Huckins, J.N., Little, E.E., and La Point, T.W., 1989, Distribution and bioaccumulation of selenium in aquatic microcosms: Environmental Pollution, v. 62, no. 1, p. 1-12.

Bowie, G.L., Sanders, J.G., Riedel, G.F., Gilmour, C.C., Breitburg, D.L., Cutter, G.A., and Porcella, D.B., 1996, Assessing selenium cycling and accumulation in aquatic systems: Water, Air and Soil Pollution, v. 90, no. 1-2, p. 93-104.

British Columbia Ministry of Environment, 2012, Draft Water Quality Guidelines for Selenium: Technical Appendix Update: British Columbia Ministry of Environment, Water Protection and Sustainability Branch, Environmental Sustainability and Strategic Policy Division, 257 p.

Brix, K.V., Toll, J.E., Tear, L.M., DeForest, D.K., and Adams, W.J., 2005, Setting site specific water quality standards by using tissue residue thresholds and bioaccumulation data. Part 2. Calculating site-specific selenium water-quality standards for protecting fish and birds: Environmental Toxicology and Chemistry, v. 24, no. 1, p. 231-237.

Brumbaugh, W.G., and Walther, M.J., 1989, Determination of arsenic and selenium in whole fish by continuous-flow hydride generation atomic absorption spectrophotometry: Journal Association of Official Analytical Chemists, v. 72, p. 484-486.

Bryant, G., and Childers, H., 2002, A survey of the water quality of streams in the primary region of mountaintop/valley fill coal mining, October 1999 to January 2001, Final Report to Mountaintop Mining/Valley Fill Programmatic Environmental Impact Assessment: U.S. Environmental Protection Agency, Draft Programmatic Environmental Impact Statement on Mountaintop Mining/Valley fills in Appalachia, Appendix D, p. 661-789, accessed August 21, 2013, at http://www.epa.gov/ region03/mtntop/eis2003appendices.htm\#appd. 
Caruccio, F.T., Ferm, J.C., Horne, J., Geidel, G., and Baganz, B., 1977, Paleoenvironment of coal and its relation to drainage quality: EPA600/7-77-067, U.S. Environmental Protection Agency, Cincinnati, Ohio, 121 p., accessed online August 21, 2013, at http://nepis.epa.gov/Exe/ZyNET.exe/930004K2.TXT? ZyActionD $=$ ZyDocument\&Client=EPA\&Index $=1976+$ Thru +1 980\&Docs $=\&$ Query $=\&$ Time $=\&$ EndTime $=\&$ SearchMethod $=1$ $\&$ TocRestrict $=$ n $\&$ Toc $=\&$ TocEntry $=\& Q$ Field $=\& Q$ FieldYear $=\&$ QFieldMonth $=\& Q$ FieldDay $=\&$ IntQFieldOp $=0 \&$ ExtQFieldOp $=$ $0 \& X m l Q u e r y=\& F i l e=D \% 3 A \backslash z y f i l e s \backslash$ Index $\% 20$ Data $\backslash 76$ thru $80 \backslash$ Txt $100000027 \backslash 930004 K 2 . t x t \& U s e r=A N O N Y M O U S \& P a s s w o$ $\mathrm{rd}=$ anonymous $\&$ SortMethod $=\mathrm{h} \mid-\&$ MaximumDocuments $=1 \& \mathrm{~F}$ uzzyDegree $=0 \&$ ImageQuality $=$ r75g8/r75g8/x150y150g16/i425 $\&$ Display $=\mathrm{p} \mid \mathrm{f} \&$ DefSeekPage $=\mathrm{x} \&$ SearchBack $=$ ZyActionL $\& B a$ $\mathrm{ck}=$ ZyActionS\&BackDesc $=$ Results $\%$ 20page $\&$ MaximumPages $=1 \&$ ZyEntry $=1 \&$ SeekPage $=\mathrm{x} \& Z y$ PURL.

Casey, R., 2005, Results of aquatic studies in the McLeod and Upper Smoky River Systems: Edmonton, Alberta, Alberta Environmental Policy Branch, Pub. No. T/785, 62 p., accessed August 20, 2013, at http://environment.gov.ab.ca/ info/library/7743.pdf.

Chambers, D.B., and Messinger, T., 2001, Benthic invertebrate communities and their responses to selected environmental factors in the Kanawha River basin, West Virginia, Virginia, and North Carolina: U.S Geological Survey Water-

Resources Investigations Report 01-4021, 61 p., accessed August 21, 2013, at http://pubs.usgs.gov/wri/wri014021.

Chapman, P.M., Adams, W.J., Brooks, M.L., Delos, C.G., Luoma, S.N., Maher, W.A., Ohlendorf, H.M., Presser, T.S., and Shaw, D.P., 2010, Ecological assessment of selenium in the aquatic environment: Pensacola, Florida, Society of Environmental Toxicology and Chemistry Press, 358 p.

Conley, J.M., Funk, D.H., and Buchwalter, D.B., 2009, Selenium bioaccumulation and maternal transfer in the mayfly Centroptilum triangulifer in a life-cycle, periphytonbiofilm trophic assay: Environmental Science and Technology, v. 43, no. 20, p. 7952-7957.

Cutter, G.A., and Bruland, K.W., 1984, The marine biogeochemistry of selenium - a reevaluation: Limnology and Oceanography, v. 29, no. 6, p. 1179-1192.

deBruyn, A., Hodaly, A., and Chapman, P.M., 2008, Tissue selection criteria; selection of tissue types for the development of a meaningful selenium tissue threshold in fish: Washington, D.C., North American Metals Council, Selenium Working Group, 32 p. and appendix I, accessed August 21, 2013, at http://www.namc.org/docs/00043675.PDF.

DeForest, D.K., Gilron, G., Armstrong, S.A., and Robertson, E.L., 2012, Species sensitivity distribution evaluation for selenium in fish eggs; considerations for development of a Canadian tissue-based guideline: Integrated Environmental Assessment and Management, v. 8, no.1, p. 6-12.
Doblin, M.A., Baines, S.B., Cutter, L.S., and Cutter, G.A., 2006, Sources and biogeochemical cycling of particulate selenium in the San Francisco Bay estuary: Estuarine, Coastal and Shelf Science, v. 67, no. 4, p. 681-694.

Fournier, E., Adam, C., Massabuau, J-C, Garnier-Laplace, J., 2006, Selenium bioaccumulation in Chlamydomonas reinhardtii and subsequent transfer to Corbicula fluminea; role of selenium speciation and bivalve ventilation: Environmental Toxicology and Chemistry, v. 25, no. 10, p. 2692-2699.

Fowler, S.W., and Benayoun, G., 1976, Influence of environmental factors on selenium flux in two marine invertebrates: Marine Biology, v. 37, no. 1, p. 59-68.

Fulk, F., Autrey, B., Huchens, J., Gerritsen, J., Burton, J., Creswell, C., and Jessup, B., 2003, Ecological assessment of streams in the coal mining region of West Virginia using data collected by the U.S. Environmental Protection Agency and environmental consulting firms, Final Report to Mountaintop Mining/Valley Fill Programmatic Environmental Impact Assessment: U.S. Environmental Protection Agency, Draft Programmatic Environmental Impact Statement on Mountaintop Mining/Valley fills in Appalachia, Appendix D, p. 955-1106, accessed August 21, 2013, at http://www.epa.gov/region03/mtntop/ eis2003appendices.htm\#appd.

Graham, R.V., Blaylock, B.G., Hoffman, F.O., and Frank, M.L., 1992, Comparison of selenomethionine and selenite cycling in freshwater experimental ponds: Water, Air, and Soil Pollution, v. 62, no. 1-2, p. 25-42.

Green, H., 2009, Selenium aquatic life criteria and implementation: Presentation to Ohio River Valley Water Sanitation Commission (ORSANCO), U.S. Environmental Protection Agency, Office of Science and Technology, Standards and Health Protection Division, 12 p.

Griffith, M.B., Norton, S.B., Alexander, L.C., Pollard, A.I., and LeDuc, S.D., 2012, The effects of mountaintop mines and valley fills on the physicochemical quality of stream ecosystems in the central Appalachians - a review: Science of the Total Environment, v. 417-418, p. 1-12.

Hamilton, S.J., and Palace, V.P., 2001, Assessment of selenium effects in lotic ecosystems: Ecotoxicology and Environmental Safety, v. 50, no. 3, p. 161-166.

Hartman, K.J., Kaller, M.D., Howell, J.W., and Sweka, J.A., 2005, How much do valley fills influence headwater streams?: Hydrobiologia, v. 532, no. 1, p. 91-102.

Hopkins, W.A., Congdon, J., and Ray, J.K., 2000, Incidence and impact of axial malformations in larval bullfrogs (Rana catesbeiana) developing in sites polluted by a coal-burning power plant: Environmental and Toxicological Chemistry, v. 19, no. 4, p. 862-868. 
Hopkins, W.A., DuRant, S.E., Staub, B.P., Rowe, C.L., and Jackson, B.P., 2006, Reproduction, embryonic development, and maternal transfer of contaminants in the amphibian Gastrophryne carolinensis:

Environmental Health Perspectives, v. 114, no. 5, p. 661-666.

Janz, D.M., 2012, Selenium, in Wood, C.W., Farrell, A.P., and Brauner, C.J., eds., Fish physiology volume 31A, Homeostasis and toxicology of essential metals: San Diego, California, Elsevier., p. 327-374.

Janz, D.M., DeForest, D.K., Brooks, M.L., Chapman, P.M., Gilron, G., Hoff, D., Hopkins, W.D., McIntyre, D.O., Mebane, C.A., Palace, V.P., Skorupa, J.P., and Wayland, M., 2010, Selenium toxicity to aquatic organisms, in Chapman, P.M., Adams, W.J., Brooks, M.L., Delos, C.G., Luoma, S.N., Maher, W.A., Ohlendorf, H.M., Presser, T.S., and Shaw, D.P., eds., Ecological assessment of selenium in the aquatic environment: Boca Raton, Florida, CRC Press, p. 141-231.

Jenkins, G., and Schaer, N., 2005, The occurrence of selenium in the Upper Kanawha Formation of the Pennsylvanian system in the southern West Virginia coal fields: Charleston, West Virginia, West Virginia Department of Environmental Protection Report, 12 p., accessed August 21, 2013, at http://wvmdtaskforce.com/proceedings/05/Jenkins.pdf.

Karr, J.R., 1981, Assessment of biotic integrity using fish communities: Fisheries, v. 6, p. 21-27.

Kiffney, P., and Knight, A., 1990, The toxicity and bioaccumulation of selenate, selenite, and seleno-Lmethionine in the cyanobacterium Anabaena flosaquae: Archives of Environmental Contamination and Toxicology, v. 19 , no. 4, p. 488-494.

Lazorchak, J.M., Klemm, D.J., and Peck, D.V., eds., 1998, Environmental monitoring and assessment programsurface waters; field operations and methods for measuring the ecological condition of wadeable streams: Washington, D.C., U.S. Environmental Protection Agency, EPA/620/R94/004F., 211 p. and appendices, accessed August 21, 2013, at http://www.epa.gov/emap/html/pubs/docs/groupdocs/ surfwatr/field/frntmatr.PDF.

Lee, B.-G., Lee, J.-S., and Luoma, S.N., 2006, Comparison of selenium bioaccumulation in the clams Corbicula fluminea and Potamocorbula amurensis; a bioenergetic modeling approach: Environmental Toxicology and Chemistry, v. 25, no. 7, p. $1933-1940$.

Lemly, A.D., 1985, Toxicology of selenium in a freshwater reservoir; implications for environmental hazard evaluation and safety: Ecotoxicology and Environmental Safety, v. 10, no. 3, p. 314-338.
Lemly, A.D., 1999, Selenium transport and bioaccumulation in aqueous ecosystems; a proposal for water-quality criteria based on hydrologic units: Ecotoxicology and Environmental Safety, v. 42, no. 2, p. 150-156.

Lemly, A.D., 2002, Selenium assessment in aquatic ecosystems; a guide for hazard evaluation and water quality criteria: New York, Springer-Verlag. 160 p.

Lindberg, T.T., Bernhardt, E.S., Bier, R., Helton, A.M., Merola, R.B., Vengosh, A., and Di Giulio, R.T., 2011, Cumulative impacts of mountaintop mining on an Appalachian watershed: Proceedings of the National Academy of Sciences of the United States of America, v. 108, no. 52, p. 20929-20934.

Luoma, S.N., and Fisher, N., 1997, Uncertainties in assessing contaminant exposure from sediments, in Ingersoll, C.G., Dillon, T., and Biddinger, G.R., eds., Ecological risk assessment of contaminated sediments: Pensacola, Florida, Society of Environmental Toxicology and Chemistry Press, p. 211-237.

Luoma, S.N., and Presser, T.S., 2009, Emerging opportunities in management of selenium contamination: Environmental Science and Technology, v. 43, no. 22, p. 8483-8487.

Luoma, S.N., and Rainbow, P.S., 2005, Why is metal bioaccumulation so variable? biodynamics as a unifying concept: Environmental Science and Technology, v. 39, no. 7, p. 1921-1931.

Luoma, S.N., and Rainbow, P.S., 2008, Metal contamination in aquatic environments; science and lateral management: New York, Cambridge University Press, 573 p.

Luoma, S.N., Johns, C., Fisher, N.S., Steinberg, N.A., Oremland, R.S., and Reinfelder, J.R., 1992, Determination of selenium bioavailability to a benthic bivalve from particulate and solute pathways: Environmental Science and Technology, v. 26, no. 3, p. 485-491.

Meseck, S.L., and Cutter, G.A., 2006, Evaluating the biogeochemical cycle of selenium in San Francisco Bay through modeling: Limnology and Oceanography, v. 51, no. 5, p. 2018-2032.

Meyer, J.L., Strayer, D.L., Wallace, J.B., Eggert, S.L., Helfman, G.S., and Leonard, N.E., 2007, The contribution of headwater streams to biodiversity in river networks: Journal of the American Water Resources Association, v. 43, no. 1, p. 86-103.

Murphy, B.R., and Willis, D.W., eds., 1996, Fisheries techniques ( $2 \mathrm{~d}$ ed.): Bethesda, Maryland, American Fisheries Society, $732 \mathrm{p}$. 
Ohlendorf, H.M., Byron, E., Covington, S., and Arenal, C., 2008, Approach for conducting site-specific assessments of selenium bioaccumulation in aquatic systems: Washington, D.C., North American Metals Council, Selenium Working Group, 118 p., accessed August 21, 2013, at http://www. namc.org/docs/00043671.PDF.

Oremland, R.S., Hollibaugh, J.T., Maest, A.S., Presser, T.S., Miller, L.G., and Culbertson, C.W., 1989, Selenate reduction to elemental selenium by anaerobic bacteria in sediments and culture; biogeochemical significance of a novel, sulfate-independent respiration: Applied and Environmental Microbiology, v. 55, no. 9, p. 2333-2343.

Orr, P.L., Guiguer, K.R., and Russel, C.K., 2006, Food chain transfer of selenium in lentic and lotic habitats of a western Canadian watershed: Ecotoxicology and Environmental Safety, v. 63, no. 3, p. 175-188.

Osmundson, B., and Skorupa, J.P., 2011, Selenium in fish tissue - prediction equations for conversion between whole body, muscle, and eggs: Grand Junction, Colorado, U.S. Fish and Wildlife Service, Environmental Contaminants Program, Off-Refuge Investigations, Final Report.

Palmer, M.A., Bernhardt, E.S., Schlesinger, W.H., Eshleman, K.N., Foufoula-Georgiou, E., Hendryx, M.S., Lemly, A.D., Likens, G,E., Loucks, O.L., Power, M.E., White, P.S., and Wilcock, P.R., 2010, Mountaintop mining consequences: Science, v. 327, no. 5692, p. 148-149.

Patnode, K., Kane, C., Ramsey, D., Rhodes, J., and Evans, B., 2005, Salamander assemblage survey of mercury and selenium contaminated headwater sites in the Appalachian mountains of Pennsylvania, Virginia, and West Virginia: United States Fish and Wildlife Service, Region 5, Wheeling West Virginia, 49 p., accessed August 21, 2013, at http:// www.fws.gov/northeast/ecologicalservices/es_test2/pdf/ FWSReport_SalamanderAssemblageSurvey_01Aug05.pdf.

Paybins, K.S., Messinger, T., Eychaner, J.H., Chambers, D.B., and Kozar, M.D., 2000, Water quality in the Kanawha-New River Basin, West Virginia, Virginia, and North Carolina, 1996-98: U.S. Geological Survey Circular 1204, 32 p. (Also available online at http://pubs.usgs.gov/circ/circ1204/.)

Pond, G.J., 2010, Patterns of Ephemeroptera taxa loss in Appalachian headwater streams (Kentucky, USA): Hydrobiologia, v. 641 p. 185-201.

Pond, G.J., Passmore, M.E., Borsuk, F.A., Reynolds, L., and Rose, C.J., 2008, Downstream effects of mountaintop coal mining; comparing biological conditions using family- and genus-level macroinvertebrate bioassessment tools: Journal of the North American Benthological Society, v. 27, no. 3, p. 717-737.
Potesta and Associates, Inc., 2011a, Summary report for aquatic life studies in the Upper Mud River Watershed: Charleston, West Virginia), Potesta and Associates Inc., report prepared for Patriot Coal Company, $131 \mathrm{p}$.

Potesta and Associates, Inc., 2011b, Evaluation of the effects of selenium on fish community and reproductive healthHughes Creek, Smithers Creek, and Bells Creek watersheds of the Kanawha River: Charleston, West Virginia, Potesta and Associates, Inc., report prepared for Massey Energy, Inc., 126 p.

Presser, T.S., and Luoma, S.N., 2006, Forecasting selenium discharges to the San Francisco Bay-Delta Estuary; ecological effects of a proposed San Luis Drain extension: U.S. Geological Survey Professional Paper 1646, 196 p. (Available online at http://pubs.usgs.gov/pp/p1646.)

Presser, T.S., and Luoma, S.N., 2009, Modeling of selenium for the San Diego Creek watershed and Newport Bay, California: U.S. Geological Survey Open-File Report 2009-1114, 48 p. , available at http://pubs.usgs.gov/ of $/ 2009 / 1114 /$.

Presser, T.S., and Luoma, S.N., 2010a, A methodology for ecosystem-scale modeling of selenium: Integrated Environmental Assessment and Management, v. 6, no. 4, p. 685-710, accessed August 21, 2013, at http://onlinelibrary. wiley.com/doi/10.1002/ieam.101/pdf.

Presser, T.S., and Luoma, S.N., 2010b, Ecosystem-scale selenium modeling in support of fish and wildlife criteria development for the San Francisco Bay-Delta Estuary, California: U.S. Geological Survey Administrative Report prepared for and released by U.S. Environmental Protection Agency, Region 9, San Francisco, California, 101 p. and Appendices A-D., accessed August 21, 2013, at http:// wwwrcamnl.wr.usgs.gov/Selenium/Library_articles/ Presser_Luoma_AR_forcombined_all1.pdf]

Presser, T.S., and Luoma, S.N., 2013, Ecosystem-scale selenium model for the San Francisco Bay-Delta Regional Ecosystem Restoration Implementation Plan (DRERIP): San Francisco Estuary and Watershed Science, v. 11, no. 1, p. 1-39, accessed August 21, 2013, at http://wwwrcamnl. wr.usgs.gov/Selenium/Library-articles/Presser_Luoma SFE\&WS_2013main.pdf.

Presser, T.S., Piper, D.Z., Bird, K.J., Skorupa, J.P., Hamilton, S.J., Detwiler, S.J., and Huebner, M.A., 2004a, The Phosphoria Formation - a model for forecasting global selenium sources to the environment, in Hein, J.R., ed., Life cycle of the Phosphoria Formation, from deposition to the post-mining environment: New York, Elsevier, p. 299-319, accessed August 21, 2013, at http://wwwrcamnl.wr.usgs.gov/ Selenium/Library_articles/chap11_global_Sel-optimized.pdf. 
Presser, T.S., Hardy, M.A., Huebner, M.A., and Lamothe, P.J., 2004b, Selenium loading through the Blackfoot River watershed: linking sources to ecosystems, in Hein, J.R., ed., Life cycle of the Phosphoria Formation, from deposition to the post-mining environment: New York, Elsevier, p. 437-466, accessed August 21, 2013, at http://wwwrcamnl. wr.usgs.gov/Selenium/Library_articles/V8.pdf.

Pyron, M., Ruffing, R.A., and Lambert, A.L., 2004, Assessment of fishes of the Presque Isle Bay watershed, Erie, Pennsylvania: Northeastern Naturalist, v. 11, no. 3, 261-272.

Reash, R., 2012, Selenium, arsenic, and mercury in fish inhabiting a fly ash exposure gradient; interspecific bioaccumulation patterns and elemental associations: Environmental Toxicology and Chemistry, v. 31, no. 4, p. 739-747.

Reiley, M.C., Stubblefield, W.A., Adams, W.J., Di Toro, D.M., Hodson, P.V., Erickson, R.J., and Keating, F.J., Jr., eds., 2003, Reevaluation of the state of the science for waterquality criteria development: Pensacola, Florida, Society of Environmental Toxicology and Chemistry Press, 224 p.

Reinfelder, J.R., and Fisher, N.S., 1991, The assimilation of elements ingested by marine copepods: Science, v. 251, no. 4995, p.794-796.

Reinfelder, J.R., Fisher, N.S., Luoma, S.N., Nichols, J.W., and Wang, W.-X., 1998, Trace element trophic transfer in aquatic organisms - a critique of the kinetic model approach: Science of the Total Environment, v. 219, no. 2-3, p. 117-135.

Riedel, G.F., Sanders, J.G., and Gilmour, C.C., 1996, Uptake, transformation, and impact of selenium in freshwater phytoplankton and bacterioplankton communities: Aquatic Microbial Ecology, v. 11, no. 1, p. 43-51.

Roditi, H.A., and Fisher, N.S., 1999, Rates and routes of trace element uptake in zebra mussels: Limnology and Oceanography, v. 44, no. 7, p. 1730-1749.

Roy, M., 2005, A detailed sequential extraction study of selenium in coal and coal-associated strata from a coal mine in West Virginia: West Virginia University, Eberly College of Arts and Sciences, Morgantown, West Virginia, Master of Science thesis, 103 p., accessed August 21, 2013, at http:// wvuscholar.wvu.edu:8881/exlibris/dt1/d3_1/apache_media/ L2V4bGlicmlzL2R0bC9kM18xL2FwYWNoZV9tZWRpY S8yMDU5Mg\%3D\%3D.pdf.

Sandholm, M., Oksanen, H.E., and Pesonen, L., 1973, Uptake of selenium by aquatic organisms: Limnology and Oceanography, v. 18, no. 3, p. 496-499.

Schlekat, C.E., Purkerson, D.G., and Luoma, S.N., 2004, Modeling selenium bioaccumulation through arthropod food webs in San Francisco Bay, California, USA: Environmental Toxicology and Chemistry, v. 23, no.12, p. 3003-3010.
Shank, M., 2003, Automated detection of mining valley fills from multi-date elevation data: Charleston, West Virginia, West Virginia Department of Environmental Protection, 7 p., accessed August 20, 2013, at http://tagis.dep.wv.gov/ tagis/projects/.

Shank, M., 2004, Development of a mining fill inventory from multi-date elevation data: Presented at Advanced Integration of Geospatial Technologies in Mining and Reclamation, December 7-9, 2004, Atlanta, Georgia, 16 p., accessed August 20, 2013, at http://tagis.dep.wv.gov/tagis/projects/.

Shank, M., 2010, Trends in mining fills and associated stream loss in West Virginia, 1984-2009: Charleston, West Virginia, West Virginia Department of Environmental Protection, 12 p. , accessed August 20, 2013, at http://tagis.dep.wv.gov/ tagis/projects/.

Short, T.M., Deweese, L.R., and Dubrovsky, N.M., 2008, Discrimination of trait-based characteristics by trace element bioaccumulation in riverine fishes: Canadian Journal of Fisheries and Aquatic Sciences, v. 65, no. 6, p. 1087-1100.

Skorupa, J.P., 1998, Selenium poisoning of fish and wildlife in nature; lessons from twelve real-world examples, in Frankenberger, W.T., Jr., and Engberg, R.A., eds., Environmental Chemistry of Selenium: New York, Marcel Dekker, p. 315-354, accessed August 22, 2013, at http://wwwrcamnl.wr.usgs.gov/ Selenium/Library_articles/SePoisoning.pdf.

Skorupa, J.P., Presser, T.S., Hamilton, S.J., Lemly, A.D., and Sample, B.E., 2004, EPA's draft tissue-based criterion-a technical review: U.S. Fish and Wildlife Report presented to U.S. Environmental Protection Agency, June 16, 2004, 35 p., accessed August 21, 2013, at http://wwwrcamnl.wr.usgs. gov/Selenium/Library_articles/skorupa_et_al_2004.pdf.

Stauffer, J.R., Jr., and Ferreri, C.P., 2002, Characterization of stream fish assemblages in selected regions of mountaintop removal/valley fill coal mining (Order no. 1P-0130-NAEX): Final Report to Mountaintop Mining/Valley Fill Programmatic Environmental Impact Assessment; Draft Programmatic Environmental Impact Statement on Mountaintop Mining/Valley fills in Appalachia, Appendix D, p.381-503, accessed August 21, 2013, at http://www.epa.gov/region03/mtntop/ eis2003appendices.htm\#appd.

Stauffer, J.R., Boltz, J.M., and White, L., 1995, Fishes of West Virginia: reprinted from The Proceedings of the Academy of Natural Sciences of Philadelphia, v. 146, p. 1_389, 389 p.

Stewart, A.R., Luoma, S.N., Schlekat, C.E., Doblin, M.A., and Hieb, K.A., 2004, Food web pathway determines how selenium affects ecosystems; a San Francisco Bay case study: Environmental Science and Technology, v. 38, no. 17, p. 4519-4526. 
Tarter, D.C., 1970, Food and feeding habits of the western blacknose dace, Rhinichthys atratulus melesgris Agassiz, in Doe Run, Meade County, Kentucky: American Midland Naturalist, v. 83, no. 1, p. 134-159.

U.S. Army Corps of Engineers, 2010, Operational draft regional guidebook for the functional assessment of highgradient ephemeral and intermittent headwater streams of western West Virginia and eastern Kentucky: Washington, D.C., U.S. Army Corps of Engineers, Wetlands Regulatory Assistance Program, Engineer Research and Development Center, 104 p., accessed August 21, 2013, at http://el.erdc. usace.army.mil/elpubs/pdf/trel10-11.pdf.

U.S. Department of the Interior, 1998, Guidelines for interpretation of the biological effects of selected constituents in biota, water, and sediment - selenium: U.S. Department of the Interior, National Irrigation Water Quality Program, Denver, Colorado, 47 p., accessed August 20, 2013, at http:/www.usbr.gov/niwqp/ guidelines/pdf/Selenium.pdf.

U.S. Environmental Protection Agency [USEPA], 1987, Ambient water quality criteria for selenium-1987: Washington, D.C., U.S. Environmental Protection Agency, Office of Water, Regulations and Standards, EPA 440/5-87-006, 121 p., available at http:/water. epa.gov/ scitech/swguidance/standards/criteria/upload/AWQC Selenium_1987.pdf.

U.S. Environmental Protection Agency [USEPA], 1996, The metals translator-guidance for calculating total recoverable permit limit from a dissolved criterion: Washington, D.C., U.S. Environmental Protection Agency, Office of Water, EPA 823-B-96-007, 30 p, appendices A-F, accessed August 21, 2013, at http://el.erdc.usace.army.mil/ elpubs/pdf/trel10-11.pdf.

U.S. Environmental Protection Agency [USEPA], 1997-1998, Mid-Atlantic Streams 1997-98 Data Sets, Fish Tissue Data (Metals): Environmental Monitoring and Assessment Program (EMAP), accessed August 20, 2013, at http://www.epa.gov/ emap/html/data/surfwatr/data/mastreams/9798/index.html.

U.S. Environmental Protection Agency [USEPA], 2003, Mountaintop mining/valley fills in Appalachia, draft programmatic environmental impact statement: Philadelphia, Pennsylvania, U.S. Environmental Protection Agency, Region 3, 669 p. and Appendices A-K, accessed August 20, 2013, at http:// www.epa.gov/Region3/mtntop/eis2003.htm.

U.S. Environmental Protection Agency [USEPA], 2004, Notice of draft aquatic life criteria for selenium and request for scientific information, data, and views: Federal Register 69 (242), p. 75541_75546, accessed August 20, 2013, at http:// www.gpo.gov/fdsys/pkg/FR-2004-12-17/html/04-27665.htm.
U.S. Environmental Protection Agency [USEPA], 2005, Mountaintop Mining /Valley Fills in Appalachia, Final Programmatic Environmental Impact Statement (EPA 9-03R-05002): Philadelphia, Pennsylvania, U.S. Environmental Protection Agency, Region 3, 507 p., accessed August 20, 2013, at http://www.epa.gov/region3/mtntop/eis2005.htm.

U.S. Environmental Protection Agency [USEPA], 2011a, Review of EPA's draft report on aquatic ecosystem effects of mountaintop mining and valley fills: Washington, D.C., USEPA Science Advisory Board, EPA-SAB-11-005, 89 p., accessed August 20, 2013, at http://water.epa.gov/lawsregs/ guidance/wetlands/mining.cfm.

U.S. Environmental Protection Agency [USEPA], 2011b, Review of field-based aquatic life benchmark for conductivity in central Appalachian streams: Washington, D.C., USEPA Science Advisory Board, EPA-SAB-11-006, 48 p., accessed August 20, 2013, at http://water.epa.gov/ lawsregs/guidance/wetlands/mining.cfm.

U.S. Environmental Protection Agency [USEPA], 2013, National Listing of Fish Advisories: Database search for USEPA, Region 3: West Virginia, accessed August 20, 2013, at http://fishadvisoryonline.epa.gov/FishTissue.aspx.

U.S. Fish and Wildlife Service [USFWS], 2005, Public comment package in response to U.S. Environmental Protection Agency's Draft Aquatic Life Criteria Document for Selenium (Federal Register 69(242):75541-75546: December 17, 2004): U.S. Fish and Wildlife Service, Washington, D.C., 23 p. and attachments.

U.S. Fish and Wildlife Service [USFWS], 2012a, Proposed Rule, Status for the diamond darter and designation of critical habitat: Federal Register 50CFR Part 17, v. 77, no. 144, 43907_43939, FWS-R5-ES-2012-0045; 4500030113, RIN 1018-AY12, accessed August 21, 2013, at http://www. gpo.gov/fdsys/pkg/FR-2012-07-26/pdf/2012-17950.pdf.

U.S. Fish and Wildlife Service [USFWS], 2012b, Technical review-Smoky Canyon Mine sitespecific selenium criterion report: Arlington, Virginia, United States Fish and Wildlife Service, Division of Environmental Quality, Environmental Contaminants Program, 26 p., 1 appendix, accessed August 21, 2013, at http://www.fws.gov/contaminants/Documents/ ReviewSmokyCanyonMineSeleniumReport.pdf.

U.S. Fish and Wildlife Service [USFWS], 2013, Endangered species status for diamond darter: Federal Register 50CFR Part 17, v. 78, no. 144, 45074-45095 FWS-R5-ES-2012-0045, 4500030113, RIN 1018-AY12, accessed August 21, 2013, at https:/www.federalregister.gov/articles/2013/07/26/2013-17938/ endangered-and-threatened-wildlife-and-plants-endangeredspecies-status-for-diamond-darter. 
U.S. Fish and Wildlife Service and National Marine Fisheries Service [USFWS and NMFS], 2000, Biological opinion for USEPA proposed rule for the promulgation of water quality standard; establishment of numeric criteria for priority toxic pollutants for the state of California: U.S. Fish and Wildlife Service and National Marine Fisheries Service, 323 p.

U.S. Geological Survey, 2006, Water data report, Guyandotte River Basin: Water Quality Records, 1 p., available at http:// wdr.water.usgs.gov/.

U.S. Geological Survey, 2008, Water data report, Guyandotte Basin, Lower Guyandotte Subbasin: Water Quality Records, 5 p., available at http://wdr.water.usgs.gov/.

Velinsky D.J., and Cutter, G.A., 1991, Geochemistry of selenium in a coastal salt marsh: Geochimica et Cosmochimica Acta, v. 55, no. 1, p. 179-191.

Wallace, J.B., and Merritt, R.W., 1980, Filter-feeding ecology of aquatic insects: Annual Review of Entomology, v. 25, p.103-132.

Walters, D.M., 2006, Development of a fish index of biotic integrity to assess the condition of West Virginia Streams: Cincinnati, Ohio, U.S. Environmental Protection Agency, Technical Support Document, EPA/600/R-06/010, 45 p., accessed August 22, 2013, at http://nepis.epa.gov/Exe/ ZyNET.exe/P100ADTD.TXT?ZyActionD $=$ ZyDocument\&C lient $=$ EPA $\& I n d e x=2006+$ Thru $+2010 \&$ Docs $=\& Q u e r y=\& T i$ $\mathrm{me}=\&$ EndTime $=\&$ SearchMethod $=1 \&$ TocRestrict $=\mathrm{n} \&$ Toc $=$ $\&$ TocEntry $=\& Q$ Field $=\& Q$ FieldYear $=\& Q$ FieldMonth $=\& Q F i$ eldDay $=\&$ IntQFieldOp $=0 \&$ ExtQFieldOp $=0 \& X \mathrm{XmlQuery}=\&$ File $=\mathrm{D} \% 3 \mathrm{~A} \% 5 \mathrm{Czy}$ files $\% 5$ CIndex $\% 20$ Data $\% 5 \mathrm{C} 06$ thru $10 \%$ 5CTxt $\% 5$ C00000025\%5CP100ADTD.txt\&User=ANONYM OUS\&Password $=$ anonymous $\&$ SortMethod $=\mathrm{h} \% 7 \mathrm{C}-\&$ Maxi mumDocuments $=1 \&$ FuzzyDegree $=0 \&$ ImageQuality $=r 75 \mathrm{~g} 8 /$ $\mathrm{r} 75 \mathrm{~g} 8 / \mathrm{x} 150 \mathrm{y} 150 \mathrm{~g} 16 / \mathrm{i} 425 \&$ Display $=\mathrm{p} \% 7 \mathrm{Cf} \&$ DefSeekPage $=$ $\mathrm{x} \&$ SearchBack=ZyActionL\&Back=ZyActionS\&BackDesc $=$ Results\%20page\&MaximumPages $=1 \& Z y$ Entry $=1 \&$ SeekPa $\mathrm{ge}=\mathrm{x} \& Z \mathrm{yPURL}$.

Wang, W.-X., 2002, Interactions of trace metals and different marine food chains: Marine Ecology Progress Series, v. 243, no. 1, p. 295-309.

Wang, W.-X., and Dei, R.C.H., 1999, Kinetic measurements of metal accumulation in two marine macroalgae: Marine Biology, v. 135, no. 1, p. 11-23.

Wang, W.-X., and Fisher, N.S., 1999, Delineating metal accumulation pathways for marine invertebrates: Science of the Total Environment, v. 237/238, p. 459-472.

Wang, W.-X., Fisher, N.S., and Luoma, S.N., 1996, Kinetic determinations of trace element bioaccumulation in the mussel Mytilus edulis: Marine Ecology Progress Series, v.140, no. 1-3, p. 91-113.
West Virginia Department of Environmental Protection [WVDEP], 2006, Discharge monitoring reports, January 1, 2004 to June 6, 2006: Charleston, West Virginia, West Virginia Department of Environmental Protection, Office of Hydrologic Protection Unit, 11 p.

West Virginia Department of Environmental Protection [WVDEP], 2009, Selenium bioaccumulation among select stream and lake fishes in West Virginia: Charleston, West Virginia, West Virginia Department of Environmental Protection, 39 p., accessed August 21, 2013, at http://www. dep.wv.gov/WWE/watershed/wqmonitoring/Documents/ Selenium/Se_Fish_Tissue_Summary_Paper_final_Feb09.pdf.

West Virginia Department of Environmental Protection [WVDEP], 2010, Selenium-induced developmental effects among fishes in select West Virginia waters: Charleston, West Virginia, West Virginia Department of Environmental Protection, 55 p., accessed August 21, 2013, at http://www. dep.wv.gov/WWE/watershed/wqmonitoring/Documents/ Selenium/Se\%20Larvae\%202010\%20final.pdf.

West Virginia Department of Health and Human Resources [WVDHHR], 2012, West Virginia sport fish consumption advisories: Charleston, West Virginia, West Virginia Department of Health and Human Resources, 6 p., accessed August 21, 2013, at http://www.wvdhhr.org/fish/printouts/ Current_Consumption_Advisories.pdf.

West Virginia Legislature, 2012, Water Pollution Control Act: West Virginia Code of State Rules, Chapter 22, Environmental Resources, Article 11, 18 p., accessed August 20, 2013, at http://www.legis.state.wv.us/ WVCODE/ChapterEntire.cfm?chap=22\&art=11.

West Virginia Office of Miners' Health Safety and Training, 2009 and 2013, Surface Mines Permits: West Virginia Directory of Surface Mines. 7 p., accessed August 20, 2013, at http://www.wvminesafety.org/2009\%20Annual\%20Figs/ SANNDIR2009.pdf.

Wolman, M.G., 1954, A method of sampling coarse river-bed material: Transactions of the American Geophysical Union, v. 35, p. 951-956.

Young, T.F., Finley, K., Adams, W.J., Besser, J., Hopkins, W.D., Jolley, D., McNaughton, E., Presser, T.S., Shaw, D.P., and Unrine, J., 2010, What you need to know about selenium, in Chapman, P.M., Adams, W.J., Brooks, M.L., Delos, C.G., Luoma, S.N., Maher, W.A., Ohlendorf, H.M., Presser, T.S., and Shaw, D.P., eds., Ecological assessment of selenium in the aquatic environment, Pensacola, Florida: Pensacola, Florida, Society of Environmental Toxicology and Chemistry Press, p. 1-45, accessed August 20, 2013, at http://wwwrcamnl.wr.usgs.gov/ Selenium/Library_articles/chapman_etal_2010_chapter3.pdf.

Zhang, Y.Q., and Moore, J.N., 1996, Selenium fractionation and speciation in a wetland system: Environmental Science and Technology, v. 30, no. 8, p. 2613-2619. 


\section{Appendixes}




\section{Appendix 1. Site Locational Information and Detailed Chemical Data for Field Sites in 2010 and 2011}

Table A1.1 Site locational detail for sample collection in southern West Virginia.

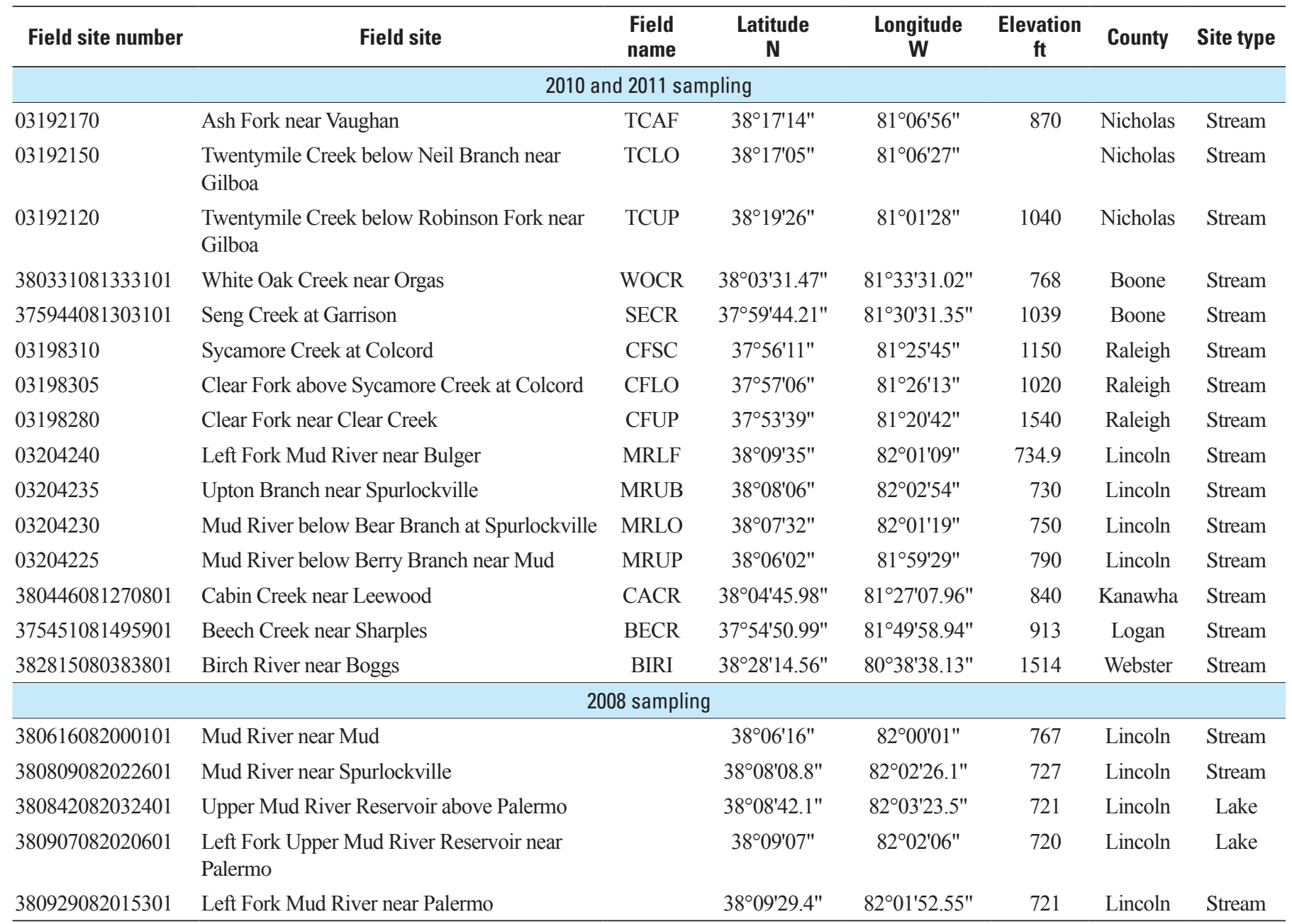


Table A1.2. Temperature and field measured water-quality data for 2010 and 2011.

[Dates in $\mathrm{m} / \mathrm{d} / \mathrm{yyyy}$ format; $\mu \mathrm{S} / \mathrm{cm}$, microsiemens per centimeter; $\mathrm{mg} / \mathrm{L}$, milligrams per liter]

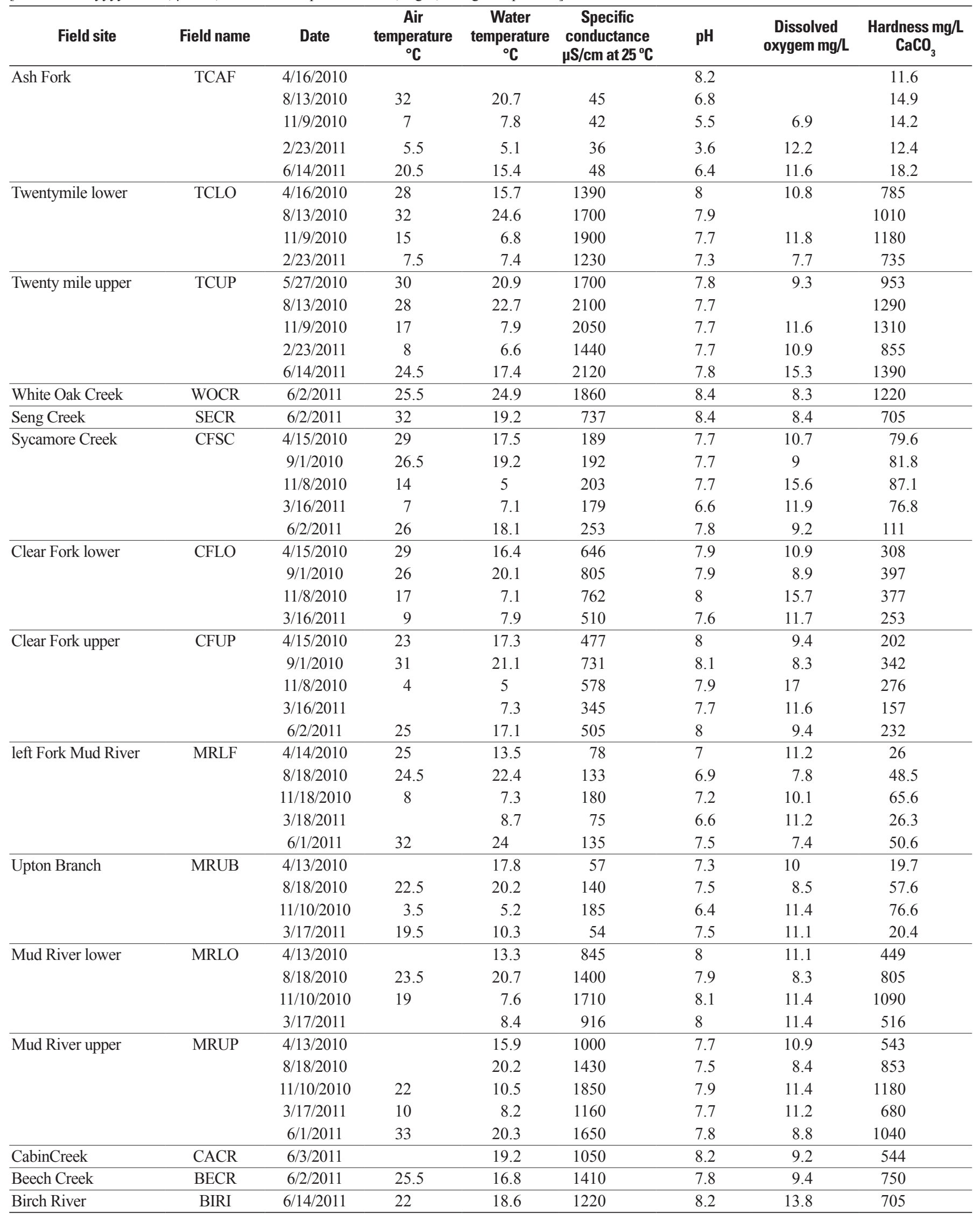


Table A1.3. Dissolved water-quality data for 2010 and 2011.

Dates in $\mathrm{m} / \mathrm{d} / \mathrm{yyyy}$ format; $\mathrm{mg} / \mathrm{L}$, milligram per liter; $\mu \mathrm{g} / \mathrm{L}$, microgram per liter; $\mathrm{E}=$ estimate]

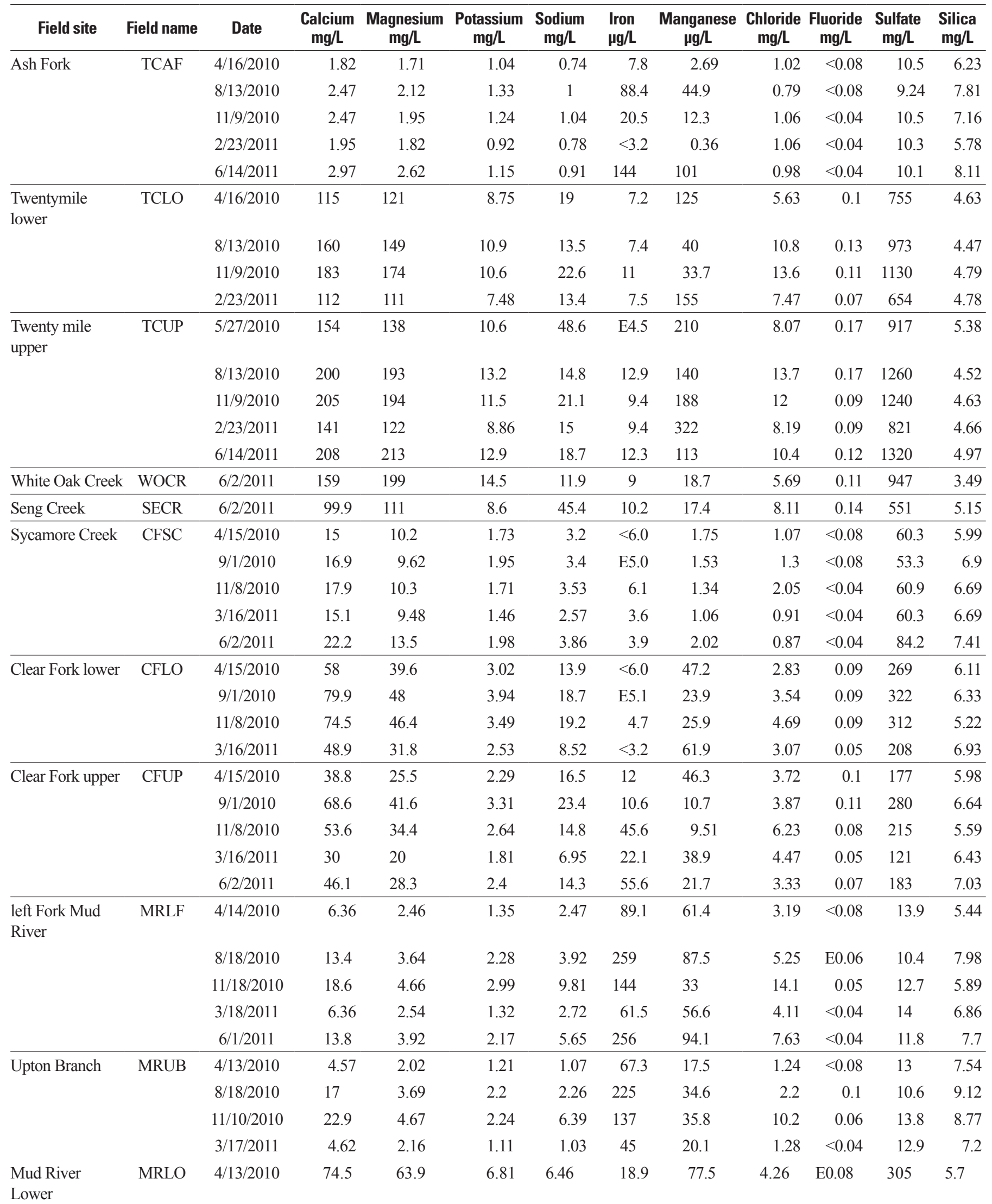


Table A1.3. Dissolved water-quality data for 2010 and 2011._- Continued

Dates in $\mathrm{m} / \mathrm{d} / \mathrm{yyyy}$ format; $\mathrm{mg} / \mathrm{L}$, milligram per liter; $\mu \mathrm{g} / \mathrm{L}$, microgram per liter; $\mathrm{E}=$ estimate]

\begin{tabular}{|c|c|c|c|c|c|c|c|c|c|c|c|c|}
\hline Field site & Field name & Date & $\begin{array}{c}\text { Calcium } \\
\mathrm{mg} / \mathrm{L}\end{array}$ & $\begin{array}{l}\text { Magnesium } \\
\mathrm{mg} / \mathrm{L}\end{array}$ & $\begin{array}{c}\text { Potassium } \\
\mathrm{mg} / \mathrm{L}\end{array}$ & $\begin{array}{c}\text { Sodium } \\
\mathrm{mg} / \mathrm{L}\end{array}$ & $\begin{array}{l}\text { Iron } \\
\mu \mathrm{g} / \mathrm{L}\end{array}$ & $\begin{array}{c}\text { Manganese } \\
\mu \mathrm{g} / \mathrm{L}\end{array}$ & $\begin{array}{c}\text { Chloride } \\
\mathrm{mg} / \mathrm{L}\end{array}$ & $\begin{array}{c}\text { Fluoride } \\
\mathrm{mg} / \mathrm{L}\end{array}$ & $\begin{array}{c}\text { Sulfate } \\
\mathrm{mg} / \mathrm{L}\end{array}$ & $\begin{array}{l}\text { Silica } \\
\text { mg/L }\end{array}$ \\
\hline & & $8 / 18 / 2010$ & 146 & 107 & 12.6 & 8.99 & 6.8 & 89.5 & 4.88 & 0.16 & 553 & 5.1 \\
\hline & & $11 / 10 / 2010$ & 189 & 150 & 13.9 & 13.8 & 10.1 & 58.8 & 8.06 & 0.11 & 772 & 4.49 \\
\hline & & $3 / 17 / 2011$ & 88.1 & 71.9 & 7.54 & 7.03 & 4.1 & 132 & 5.72 & 0.06 & 344 & 5.65 \\
\hline \multirow[t]{3}{*}{ Mud River upper } & MRUP & $4 / 13 / 2010$ & 88.4 & 78.4 & 8.18 & 7.71 & 17.9 & 133 & 4.87 & 0.12 & 379 & 5.68 \\
\hline & & $3 / 17 / 2011$ & 116 & 94.7 & 9.72 & 8.56 & 5 & 210 & 6.34 & 0.09 & 453 & 5.39 \\
\hline & & $6 / 1 / 2011$ & 187 & 140 & 14 & 10.8 & 7.1 & 151 & 5.78 & 0.13 & 703 & 4.82 \\
\hline CabinCreek & CACR & $6 / 3 / 2011$ & 95.9 & 74.1 & 6.75 & 32.5 & 3.2 & 312 & 5.67 & 0.15 & 479 & 9.04 \\
\hline Beech Creek & BECR & $6 / 2 / 2011$ & 123 & 107 & 11.7 & 55.6 & 6.3 & 60.7 & 18.7 & 0.17 & 508 & 5.19 \\
\hline
\end{tabular}

\section{Appendix 2. Fish Weight and Length}

Table A2.1. Fish weight, standard length, total length, and percent moisture for whole-body samples analyzed for Se concentrations in 2010 and 2011.

[Standard length is excluding length of the caudal fin; dates in $\mathrm{m} / \mathrm{d} / \mathrm{yy}$ format; g, grams; $\mu \mathrm{g} / \mathrm{g} \mathrm{dw}$, micrograms per gram dry weight]

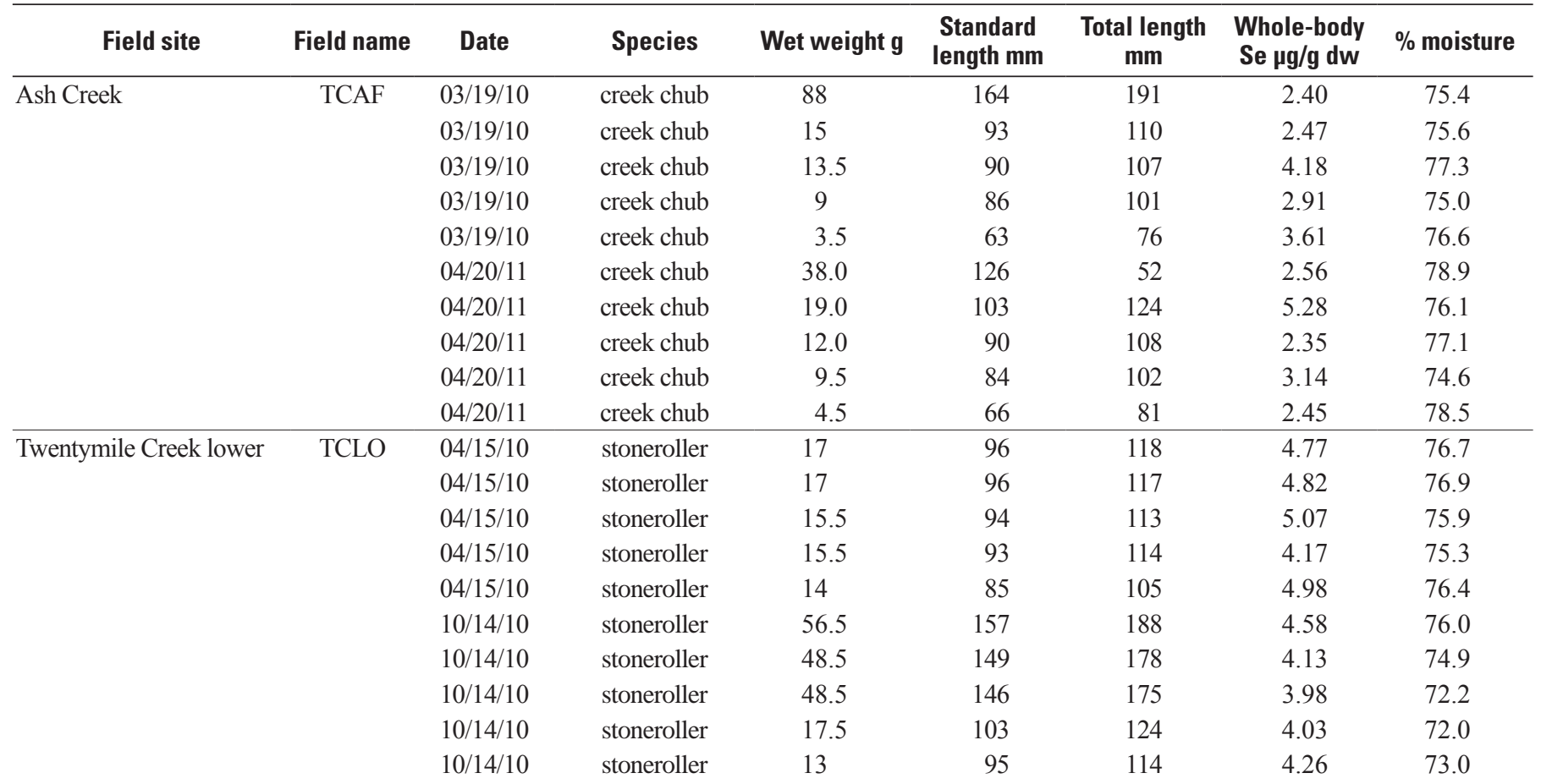


Table A2.1. Fish weight, standard length, total length, and percent moisture for whole-body samples analyzed for selenium (Se) concentrations in 2010 and 2011.-Continued

[Standard length is excluding length of the caudal fin; dates in $\mathrm{m} / \mathrm{d} / \mathrm{yy}$ format; $\mathrm{g}$, grams; $\mu \mathrm{g} / \mathrm{g} \mathrm{dw}$, micrograms per gram dry weight]

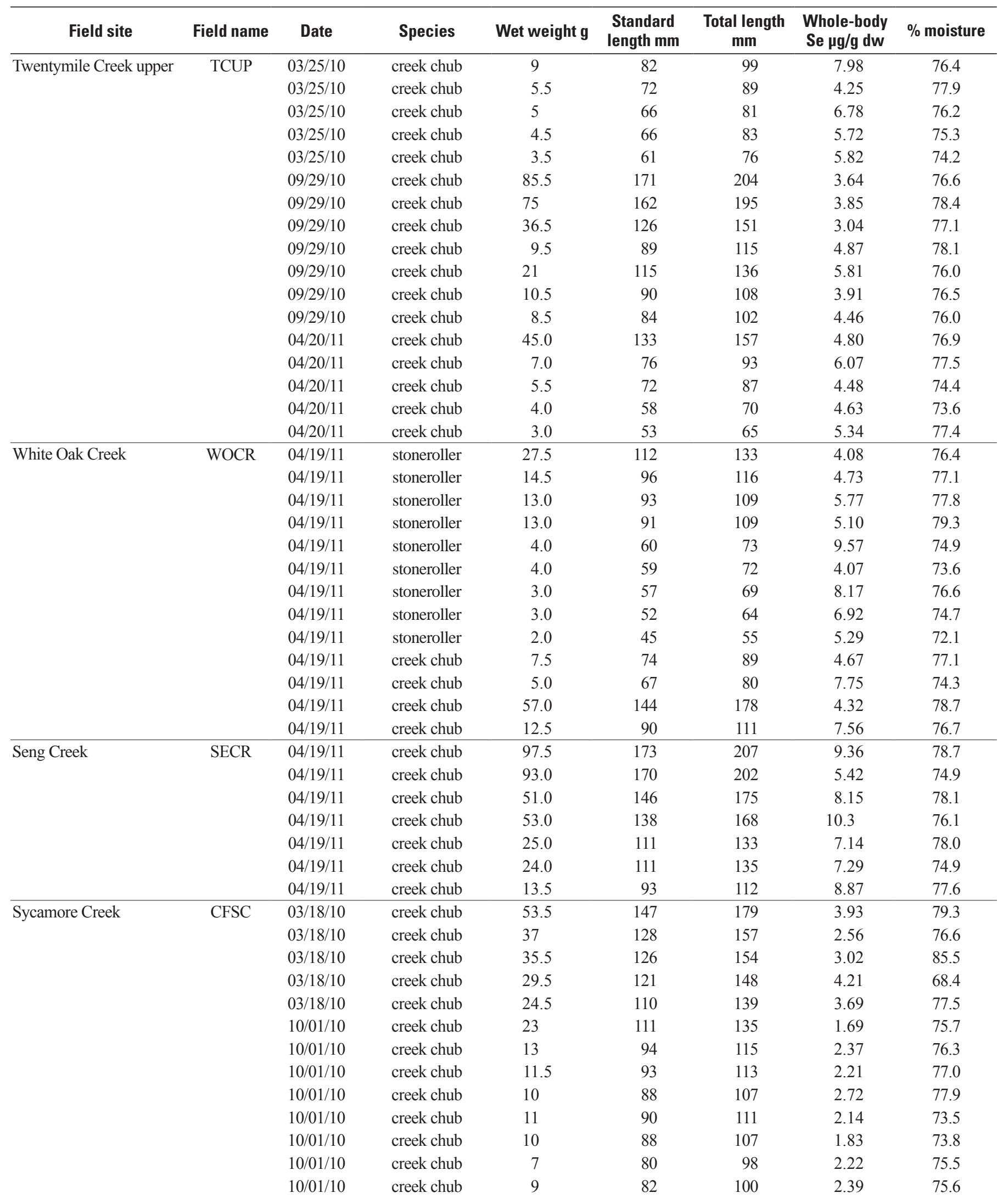


Table A2.1. Fish weight, standard length, total length, and percent moisture for whole-body samples analyzed for selenium (Se) concentrations in 2010 and 2011.-Continued

[Standard length is excluding length of the caudal fin; dates in m/d/yy format; g, grams; $\mu \mathrm{g} / \mathrm{g} \mathrm{dw}$, micrograms per gram dry weight]

\begin{tabular}{|c|c|c|c|c|c|c|c|c|}
\hline Field site & Field name & Date & Species & Wet weight g & $\begin{array}{l}\text { Standard } \\
\text { length mm }\end{array}$ & $\begin{array}{c}\text { Total length } \\
\text { mm }\end{array}$ & $\begin{array}{l}\text { Whole-body } \\
\text { Se } \mu \mathrm{g} / \mathrm{g} \mathrm{dw}\end{array}$ & $\%$ moisture \\
\hline & & $10 / 01 / 10$ & creek chub & 4 & 61 & 75 & 2.30 & 75.4 \\
\hline & & $10 / 01 / 10$ & creek chub & 3.5 & 60 & 73 & 2.16 & 73.8 \\
\hline & & $04 / 18 / 11$ & creek chub & 14.5 & 93 & 114 & 3.57 & 75.8 \\
\hline & & $04 / 18 / 11$ & creek chub & 5.0 & 67 & 82 & 2.68 & 76.1 \\
\hline \multirow[t]{9}{*}{ Clear Fork lower } & CFLO & $04 / 15 / 10$ & stoneroller & 35 & 118 & 138 & 4.76 & 76.0 \\
\hline & & $04 / 15 / 10$ & stoneroller & 32.5 & 119 & 141 & 4.56 & 78.3 \\
\hline & & $04 / 15 / 10$ & stoneroller & 10.5 & 85 & 100 & 4.74 & 73.5 \\
\hline & & $10 / 13 / 10$ & stoneroller & 52 & 143 & 173 & 5.16 & 72.9 \\
\hline & & $10 / 13 / 10$ & stoneroller & 32 & 123 & 149 & 5.81 & 76.9 \\
\hline & & $10 / 13 / 10$ & stoneroller & 14.5 & 96 & 115 & 4.24 & 71.1 \\
\hline & & $10 / 13 / 10$ & stoneroller & 12 & 93 & 111 & 4.55 & 72.1 \\
\hline & & $10 / 13 / 10$ & stoneroller & 11.5 & 91 & 109 & 4.93 & 70.8 \\
\hline & & $10 / 13 / 10$ & stoneroller & 9.5 & 83 & 100 & 4.20 & 70.0 \\
\hline \multirow[t]{13}{*}{ Clear Fork upper } & CFUP & $03 / 18 / 10$ & creek chub & 29.5 & 115 & 139 & 3.01 & 74.8 \\
\hline & & $03 / 18 / 10$ & creek chub & 13 & 97 & 108 & 2.57 & 73.4 \\
\hline & & $03 / 18 / 10$ & creek chub & 9 & 78 & 97 & 2.74 & 76.3 \\
\hline & & $03 / 18 / 10$ & creek chub & 8 & 77 & 95 & 2.80 & 75.4 \\
\hline & & $03 / 18 / 10$ & creek chub & 7.5 & 73 & 90 & 2.26 & 75.7 \\
\hline & & $10 / 13 / 10$ & creek chub & 48.5 & 145 & 176 & 1.47 & 74.8 \\
\hline & & $10 / 13 / 10$ & creek chub & 14.5 & 98 & 117 & 1.53 & 72.3 \\
\hline & & $10 / 13 / 10$ & creek chub & 4 & 63 & 76 & 2.39 & 75.1 \\
\hline & & $04 / 18 / 11$ & creek chub & 40.0 & 126 & 154 & 2.65 & 76.3 \\
\hline & & $04 / 18 / 11$ & creek chub & 23.0 & 106 & 130 & 2.35 & 77.9 \\
\hline & & $04 / 18 / 11$ & creek chub & 93.0 & 173 & 207 & 2.56 & 75.9 \\
\hline & & $04 / 18 / 11$ & creek chub & 79.0 & 160 & 191 & 2.38 & 76.7 \\
\hline & & $04 / 18 / 11$ & creek chub & 10.5 & 81 & 101 & 2.49 & 73.8 \\
\hline \multirow[t]{10}{*}{ Left fork Mud River } & MRLF & $03 / 23 / 10$ & creek chub & 8.5 & 78 & 94 & 3.67 & 75.7 \\
\hline & & $03 / 23 / 10$ & creek chub & 6.5 & 75 & 89 & 2.93 & 72.6 \\
\hline & & $03 / 23 / 10$ & creek chub & 5 & 70 & 83 & 3.73 & 75.0 \\
\hline & & $03 / 23 / 10$ & creek chub & 5 & 66 & 81 & 3.02 & 74.7 \\
\hline & & $03 / 23 / 10$ & creek chub & 4.5 & 64 & 76 & 3.13 & 76.8 \\
\hline & & $09 / 30 / 10$ & creek chub & 11 & 90 & 110 & 1.97 & 74.0 \\
\hline & & $09 / 30 / 10$ & creek chub & 7.5 & 78 & 96 & 1.99 & 77.0 \\
\hline & & $09 / 30 / 10$ & creek chub & 9 & 83 & 101 & 1.40 & 74.1 \\
\hline & & $09 / 30 / 10$ & creek chub & 23.5 & 120 & 144 & 2.28 & 78.8 \\
\hline & & 09/30/10 & creek chub & 14 & 99 & 120 & 1.39 & 75.2 \\
\hline
\end{tabular}


Table A2.1. Fish weight, standard length, total length, and percent moisture for whole-body samples analyzed for selenium (Se) concentrations in 2010 and 2011.-Continued

[Standard length is excluding length of the caudal fin; dates in $\mathrm{m} / \mathrm{d} / \mathrm{yy}$ format; $\mathrm{g}$, grams; $\mu \mathrm{g} / \mathrm{g} \mathrm{dw}$, micrograms per gram dry weight]

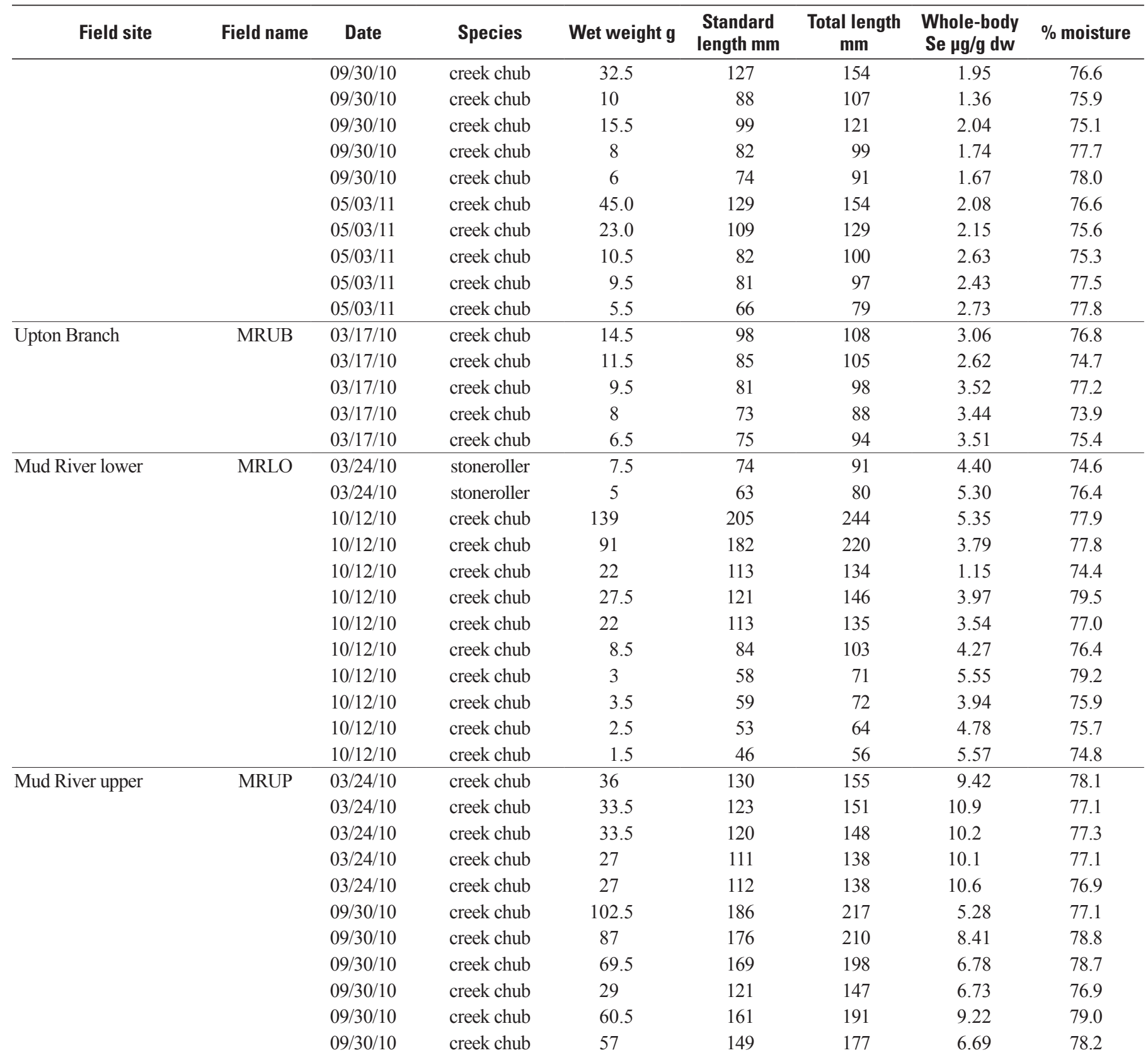


Table A2.1. Fish weight, standard length, total length, and percent moisture for whole-body samples analyzed for selenium (Se) concentrations in 2010 and 2011.-Continued

[Standard length is excluding length of the caudal fin; dates in $\mathrm{m} / \mathrm{d} / \mathrm{yy}$ format; $\mathrm{g}$, grams; $\mu \mathrm{g} / \mathrm{g} \mathrm{dw}$, micrograms per gram dry weight]

\begin{tabular}{|c|c|c|c|c|c|c|c|c|}
\hline Field site & Field name & Date & Species & Wet weight g & $\begin{array}{l}\text { Standard } \\
\text { length mm }\end{array}$ & $\begin{array}{l}\text { Total length } \\
\text { mm }\end{array}$ & $\begin{array}{l}\text { Whole-body } \\
\text { Se } \mu \mathrm{g} / \mathrm{g} \mathrm{dw}\end{array}$ & $\%$ moisture \\
\hline & & $09 / 30 / 10$ & creek chub & 28.5 & 122 & 148 & 5.18 & 76.3 \\
\hline & & $09 / 30 / 10$ & creek chub & 20.5 & 113 & 136 & 7.45 & 78.6 \\
\hline & & $09 / 30 / 10$ & creek chub & 37 & 137 & 164 & 6.11 & 79.2 \\
\hline & & $05 / 02 / 11$ & creek chub & 78.0 & 155 & 189 & 7.97 & 76.5 \\
\hline & & $05 / 02 / 11$ & creek chub & 30.5 & 118 & 143 & 11.1 & 77.2 \\
\hline \multirow[t]{5}{*}{ Cabin Creek } & CACR & $04 / 21 / 11$ & creek chub & 8.5 & 79 & 96 & 5.79 & 76.5 \\
\hline & & $04 / 21 / 11$ & creek chub & 143.0 & 202 & 240 & 6.33 & 75.2 \\
\hline & & $04 / 21 / 11$ & creek chub & 24.0 & 113 & 139 & 7.06 & 78.0 \\
\hline & & $04 / 21 / 11$ & creek chub & 11.5 & 87 & 104 & 7.20 & 78.4 \\
\hline & & $04 / 21 / 11$ & creek chub & 24.0 & 84 & 105 & 11.2 & 71.7 \\
\hline \multirow[t]{9}{*}{ Beech Creek } & BECR & $04 / 20 / 11$ & creek chub & 4.0 & 61 & 74 & 6.85 & 77.7 \\
\hline & & $04 / 20 / 11$ & stoneroller & 17.5 & 96 & 117 & 4.85 & 73.8 \\
\hline & & $04 / 20 / 11$ & stoneroller & 20.5 & 105 & 124 & 5.90 & 76.1 \\
\hline & & $04 / 20 / 11$ & stoneroller & 15.5 & 78 & 118 & 5.90 & 75.0 \\
\hline & & $04 / 20 / 11$ & stoneroller & 17.0 & 99 & 117 & 4.99 & 73.7 \\
\hline & & $04 / 20 / 11$ & stoneroller & 16.0 & 95 & 114 & 3.82 & 69.4 \\
\hline & & $04 / 20 / 11$ & stoneroller & 14.0 & 101 & 121 & 4.03 & 76.0 \\
\hline & & $04 / 20 / 11$ & stoneroller & 11.5 & 84 & 101 & 5.66 & 74.9 \\
\hline & & $04 / 20 / 11$ & stoneroller & 12.5 & 87 & 103 & 5.19 & 72.7 \\
\hline \multirow{5}{*}{ Birch River } & & $04 / 20 / 11$ & creek chub & 24.5 & 112 & 133 & 4.30 & 76.1 \\
\hline & & $04 / 20 / 11$ & creek chub & 15.0 & 94 & 114 & 6.19 & 78.0 \\
\hline & & $04 / 20 / 11$ & creek chub & 8.5 & 77 & 95 & 5.58 & 78.1 \\
\hline & & $04 / 20 / 11$ & creek chub & 5.5 & 67 & 84 & 5.56 & 77.6 \\
\hline & & $04 / 20 / 11$ & creek chub & 3.5 & 57 & 70 & 7.48 & 76.6 \\
\hline
\end{tabular}


Table A2.2. Fish weight, standard length, and total length for corresponding ovary samples analyzed for selenium (Se) concentrations in 2010 and 2011.

[Standard length is excluding length of the caudal fin; dates in $\mathrm{m} / \mathrm{d} / \mathrm{yy}$ format; $\mathrm{g}$, grams; $\mu \mathrm{g} / \mathrm{g} \mathrm{dw}$, micrograms per gram dry weight]

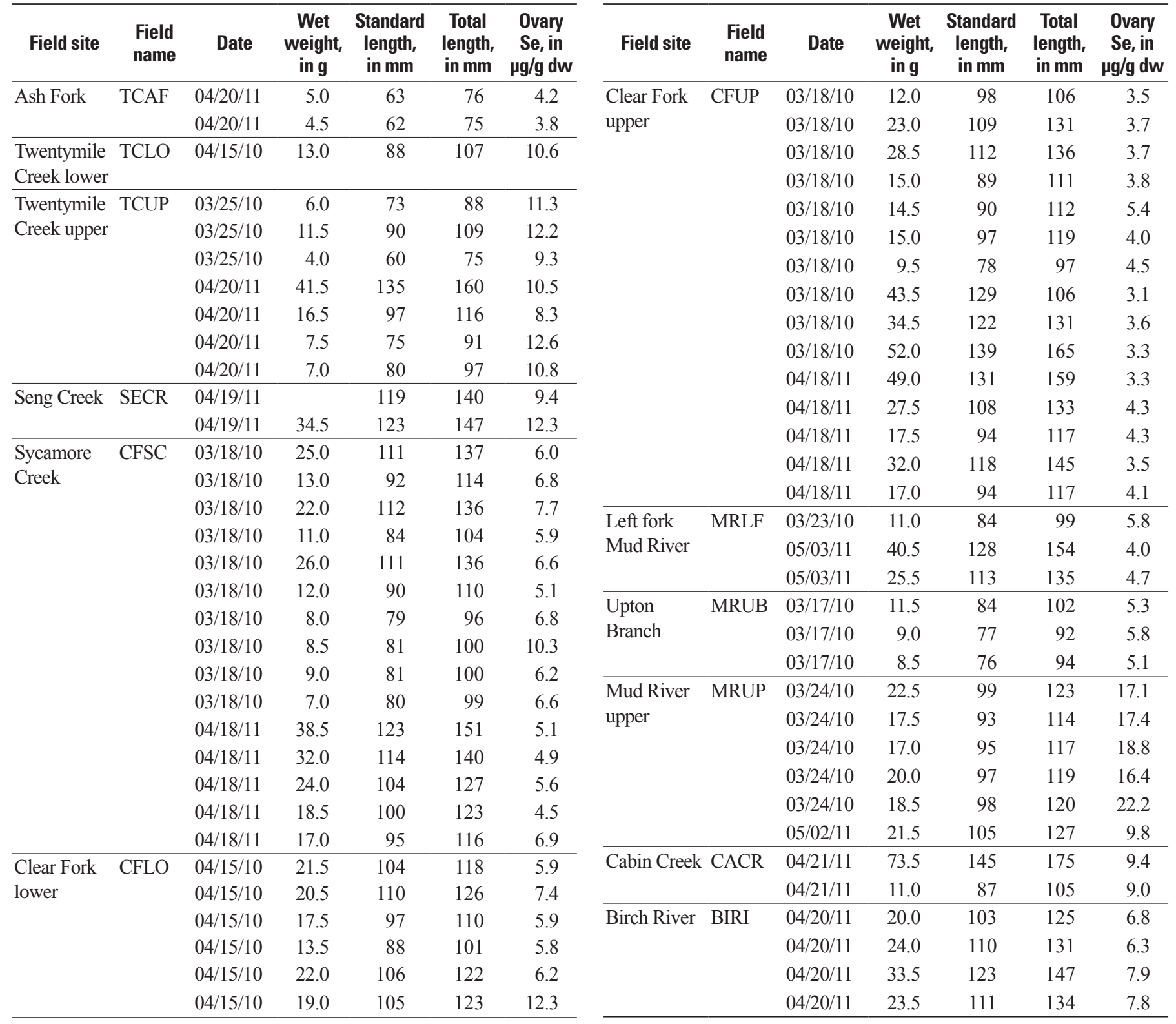


Menlo Park Publishing Service Center, California

Manuscript approved for publication December 13, 2013

Edited by Peter H. Stauffer

Design and layout by Jeanne S. DiLeo 
奇

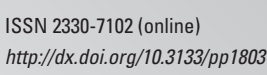

